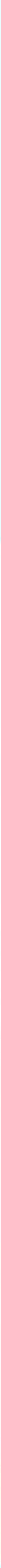

\title{
ВНИМАНИЮ АВТОРОВ!
}

Tеперь ваши статьи доступны в международных базах:

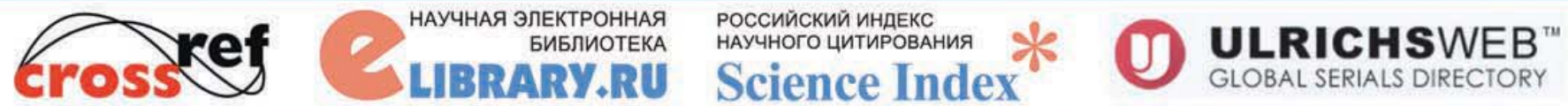

I. $\begin{aligned} & \text { Academic } \\ & \text { Resource } \\ & \frac{\text { Index }}{\text { ResearchBib }}\end{aligned}$ iNFOBASE INDEX




\section{Уважаемые коллеги! Дорогие Врачи!}

Группа компаний «МедЭксперт»

сердечно поздравляет Вас

с профессиональным празником Днем медицинского работника!

Ваш ежедневный труд - образец самоотверженности и профессионализма, милосердия и ответственности, заботы и твердой решимости!

Вы оберегаете самое ценное - жизни людей. Вы рядом с нами с первых и до последних дней. Благодаря Вашей работе мы живем, радуемся новому, любуемся прекрасным и движемся вперед!

Поэтому сегодня, в который раз, мы говорим Вам СПАСИБО! Спасибо за жизнь! Спасибо за поддержку! Спасибо за уверенность!

Крепкого Вам здоровья, счастья, благополучия! Вдохновения, нескончаемой энергии, осуществления всех желаний и надежд! Новых идей и побед! Надежных партнеров и верных друзей! Всех благ Вашим семьям и мира нашей Стране!

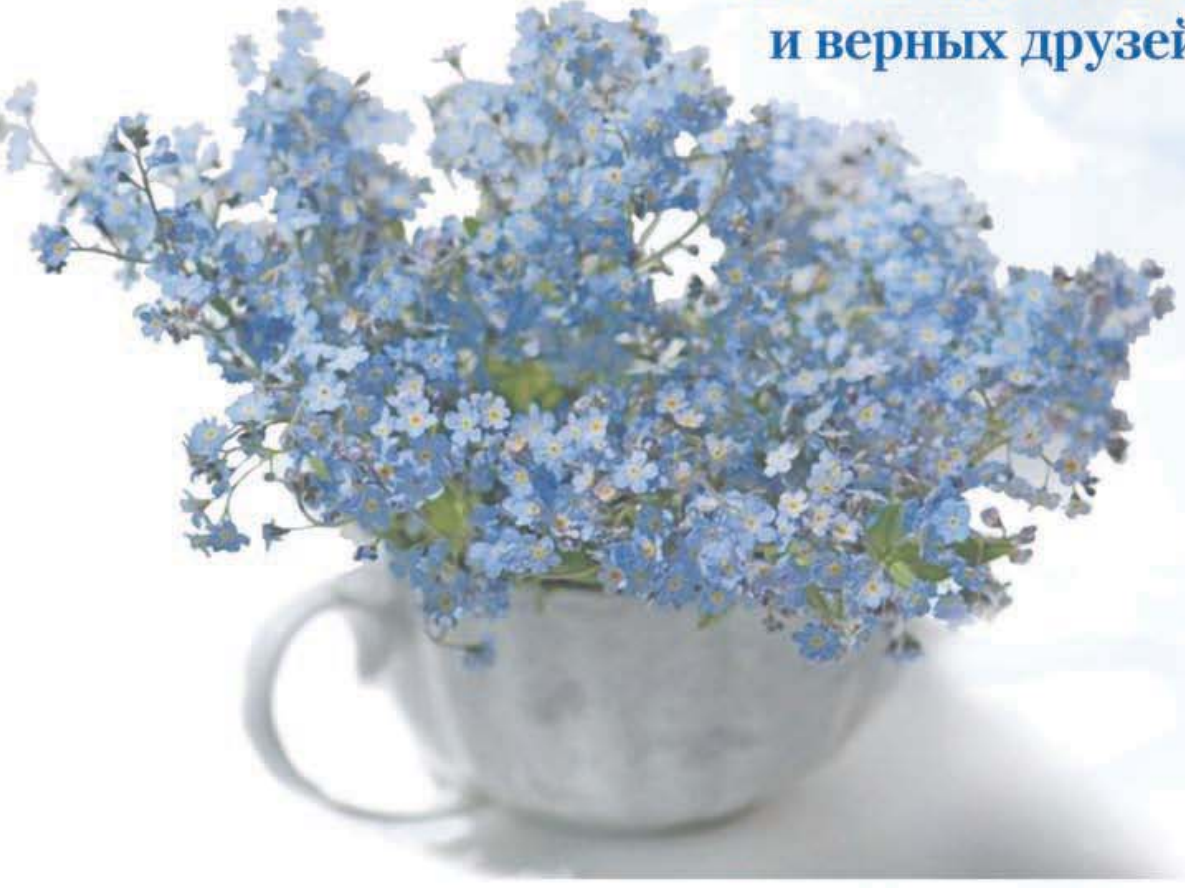

С уважением и любовью

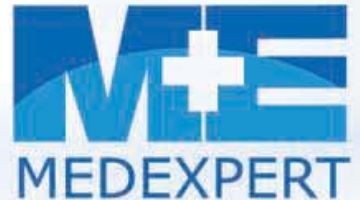




\title{
НАЦІОНАЛЬНА АКАДЕМІЯ МЕДИЧНИХ НАУК УКРАЇНИ ДЕРЖАВНА УСТАНОВА «ІНСТИТУТ ПЕДІАТРІЇ, АКУШЕРСТВА І ГІНЕКОЛОГЇ̈ НАМН УКРАЇНИ ПЕРИНАТОЛОГИЯ И ПЕДИАТРИЯ \\ Научно-практический журнал
}

\section{ПЕРИНАТОЛОГІЯ ТА ПЕДІАТРІЯ}

Науково-практичний журнал

\author{
ГОЛОВНИЙ РЕДАКТОР: Антипкін Юрій Геннадійович \\ Академік НАН, НАМН України, д.м.н., професор, директор Державної установи «Інститут педіатрї, \\ акушерства і гінекологї̈, НАМН Украӥни, м. Київ \\ ЗАСТ. ГОЛОВНОГО РЕДАКТОРА: Омельченко Людмила Іванівна \\ д.м.н., професор, заст. директора ДУ «IПАГ» НАМН Украӥни, м. Киӥв \\ НАУКОВІ КОНСУЛЬТАНТИ: Дронова Вікторія Леонідівна \\ д.м.н., ст.н.с., заст. директора ДУ «ІПАГ» НАМН Украйни, м. Київ \\ Волосовець Олександр Петрович \\ д.м.н., професор, зав. кафедри педіатрії № 2 Начіонального медичного університету ім. О.О.Богомольия, м. Киӥв \\ ВЧЕНИЙ СЕКРЕТАР: Квашніна Людмила Вікторівна \\ д.м.н., професор, завідувач відділення медичних проблем здорової дитини та преморбідних станів \\ Державної установи «нститут педіатрії, акушерства і гінекологї̈ НАМН України, м. Київ \\ ДИРЕКТОР ПРОЕКТУ: Бахтіярова Дана Олегівна \\ ВЕРСТКА ТА ДИЗАЙН: Щербатих Володимир Станіславович
}

Абатуров Олександр Євгенійович Айсберг Юрій Рувімович

Бережний В'ячеслав Володимирович

Венцківський Борис Михайлович

Вовк Ірина Борисівна

Волосянко Андрій Богданович

Гнатейко Олег Зиновійович

Гордієнко Ірина Юріївна

Грищенко Валентин Іванович

Губертус фон Фосс (Німеччина)

\section{РЕДАКЦІЙНА КОЛЕГІЯ:}

Дука Катерина Дмитрівна

Задорожна Тамара Данилівна

Запорожан Валерій Миколайович

Знаменська Тетяна Костянтинівна

Іванюта Лідія Іванівна

Коломійцева Антоніна Георгіївна

Козлов Роман Сергійович(Росія)

Коровина Ніна Олексї̈вна (Росія)

Лаббе Андре (Франиія)

Мізерницький Юрій Леонідович (Росія)
Осидак Людмила Вікторівна (Росія)

Пагава Караман (Грузія)

Пісарєва Світлана Петрівна

Подольський Василь Васильович

Усоніс Вітас (Литва)

Ципкун Анатолій Григорович

Шамсієв Ф.С. (Узбекістан)

Шишко Г.А. (Білорусъ)

\section{РЕДАКЦІЙНА РАДА:}

Аряєв Микола Леонідович Банадига Наталія Василівна Бєсєдін Віктор Михайлович Волосовець Олександр Петрович Гойда Ніна Григорівна Денисова Маргарита Федорівна Євтушенко Станіслав Костянтинович Кирилова Людмила Григорівна Коренєв Микола Михайлович
Крамарєв Сергій Олександрович Коржинський Юрій Степанович Крючко Тетяна Олександрівна Лапшин Володимир Федорович Майданник Віталій Григорович Маркін Леонід Борисович Моісеєнко Раїса Олександрівна Неділько Віктор Петрович Няньковський Сергій Леонідович
Сенаторова Ганна Сергіївна Сулима Олена Григорівна Тищенко Валентина Андріївна Тяжка Олександра Василівна Туманова Лариса Євгенівна Чайка Володимир Кирилович Чернишов Віктор Павлович Шунько Єлизавета Євгенівна

Постановою Президії ВАК України № 1-05/4 від 26.05.2010 р. журнал «Перинатологія та педіатрія» включено до переліку наукових видань України, в яких можуть публікуватися результати дисертаційних робіт на здобуття наукових фахових ступенів доктора і кандидата наук.

Журнал «Перинатологія та педіатирія» реферується Інститутом проблем реєстрації інформації НАН України

\section{ВИДАВЦІ}

НАЦІОНАЛЬНА АКАДЕМІЯ МЕДИЧНИХ НАУК УКРАЇНИ ДУ «ІНСТИТУТ ПЕДІАТРІЇ, АКУШЕРСТВА І ГІНЕКОЛОГІЇ» НАМН УКРАЇНИ ВИДАВНИЦТВО «ЕКСПЕРТ »

Атестовано Вищою атестаційною комісією України № 1-05 /4 від 26.05.2010 р.

Адреса для листування: Україна, 04210, м.Київ-210, а/я 32,

E-mail: pediatr@med-expert.com.ua; seminar@med-expert.com.ua http://medexpert.org.ua/

Свідоцтво про державну реєстрацію КВ № 15781-4253 ПР від 24.09.2009 р. Видається з 1999 p.

Періодичність виходу - щоквартально

Рекомендовано вченою радою ДУ «Інститут педіатрії, акушерства і гінекології НАМН України» Протокол № 6 від 24.06 .2015 р. Підписано до друку 26.06 .2015 р.

Формат 60x90/8. Папір офсетний. Ум. друк. арк. 17. Об л.-вид. арк. 13,95

Загальний наклад 8000 прим. Зам. №26.06/01 від 26.06.2015

Видруковано у друкарні «Аврора-принт»,

Свідоцтво суб'єкта видавничої справи: А00 № 777897 від 06.07.2009 p.

м. Київ, вул. Причальна, 5 , тел. (044) 550-52-44

Передплатити «Перинатологію та педіатрію» можна в будь-якому поштовому відділені. Передплатний індекс 22811

Усі статті рецензовані. Цілковито або часткове розмножування в будь-який спосіб матеріалів, опублікованих у цьому виданні, допускається лише з письмового дозволу редакції. Відповідальність за зміст рекламних матеріалів несе рекламодавець

Журнал «Перинатология и Педиатрия» включен в наукометрические базы данных:

«Джерело», РИНЦ, Science index (eLIBRARY.RU) и Google Scholar, Ulrich, Academic Resourse Index, Infobase index. Статьям журнала «Перинатология и Педиатрия» присваивается DOI

(с ДУ «Інститут педіатрії, акушерства і гінекології» НАМН України, 2015 СВидавництво «Експерт», 2015 


\title{
PERINATOLOGY AND PEDIATRICS
}

\author{
Scientific and Practical journal
}

\begin{tabular}{|c|c|c|}
\hline of healthy child and & $\begin{array}{l}\text { HEAD EDITOR: Antypkin Iurii } \\
\text { an of the NAS, NAMS of Ukraine, Russi } \\
\text { essor of the Medical Sciences, Professor, A } \\
\text { ute of Pediatrics, Obstetrics and Gynecol } \\
\text { PUTY HEAD EDITOR: Omelchen } \\
\text { ate Professor of the Medical Sciences, Pro } \\
\text { titute of Pediatrics, Obstetrics and Gynec } \\
\text { aIENTIFIC ADVISERS: Dronova V } \\
\text { ate Professor of the Medical Sciences, Pro } \\
\text { titute of Pediatrics, Obstetrics and Gynec } \\
\text { Volosovets Oleksandr P }\end{array}$ & $\begin{array}{l}\text { tion and Science Department, } \\
\text { Health of Ukraine } \\
\text { roblems } \\
\text { recology NAMS of Ukraine» Kyiv } \\
\text { vych }\end{array}$ \\
\hline $\begin{array}{l}\text { ABATUROV O.E. } \\
\text { AISBERG I.R. } \\
\text { BEREZHNYI V.V. } \\
\text { VENTSKIVSKYY B.M. } \\
\text { VOVK I.B. } \\
\text { VOLOSYANKO A.B. } \\
\text { GNATEIKO O.Z. } \\
\text { GORDIENKO I.I. } \\
\text { GRYSHCHENKO V.I. } \\
\text { HUBERTUS VON VOSS (Germany) }\end{array}$ & $\begin{array}{l}\quad \text { EDITORIAL ST } \\
\text { DUKA K.D. } \\
\text { ZADOROZHNA T.D. } \\
\text { ZAPOROZHAN V.M. } \\
\text { ZNAMENSKA T.K. } \\
\text { IVANYUTA L.I. } \\
\text { KOLOMIYTSEVA A.G. } \\
\text { KOZLOV R.S. (Russia) } \\
\text { KOROVINA N.A. (Russia) } \\
\text { LABBE A. (France) } \\
\text { MIZERNICKIY Y.L. (Russia) }\end{array}$ & $\begin{array}{l}\text { OSIDAK L.V. (Russia) } \\
\text { PAGAVA K.I. (Georgia) } \\
\text { PISARYEVA S.P. } \\
\text { PODOLSKYI V.V. } \\
\text { USONIS V. (Lithuania) } \\
\text { TSYPKUN A.G. } \\
\text { SHAMSIEV F.S. (Uzbekistan) } \\
\text { SHYSHKO G.O. (Belarus) }\end{array}$ \\
\hline \multicolumn{3}{|c|}{ EDITORIAL BOARD: } \\
\hline $\begin{array}{l}\text { ARYAYEV M.L. } \\
\text { BANADYGA N.V. } \\
\text { BESEDIN V.M. } \\
\text { VOLOSOVETS O.P. } \\
\text { GOIDA N.G. } \\
\text { DENYSOVA M.F. } \\
\text { EVTUSHENKO S.K. } \\
\text { KYRYLOVA L.G. } \\
\text { KORENYEV M.M. }\end{array}$ & $\begin{array}{l}\text { KRAMARYOV S.O. } \\
\text { KORZHYNSKYI I.S. } \\
\text { KRYUCHKO T.O. } \\
\text { LAPSHYN V.F. } \\
\text { MAIDANNYK V.G. } \\
\text { MARKIN L.B. } \\
\text { MOISEYENKO R.O. } \\
\text { NEDIL'KO V.P. } \\
\text { NYAN'KOVSKYI S.L. }\end{array}$ & $\begin{array}{l}\text { SANATOROVA G.S. } \\
\text { SULIMA O.G. } \\
\text { TYSHCHENKO V.A. } \\
\text { TYAZHKA O.V. } \\
\text { TUMANOVA L.E. } \\
\text { CHAIKA V.K. } \\
\text { CHERNYSHOV V.P. } \\
\text { SHUL'KO E.E. }\end{array}$ \\
\hline
\end{tabular}

By the Order of the Presidium of HSC of Ukraine № 1-05/4 of 26.05.2010 journal "Perinatology and Pediatrics» is included to the list of scientific publications of Ukraine, in which can be published the results of thesis works and achievement of the scientific levels of doctor and candidate of sciences.

The journal «Perinatology and Pediatrics» abstracted by the Institute of Information Recording Problems of Ukraine

PUBLISHERS

NATIONAL ACADEMY OF MEDICAL SCIENCES OF UKRAINE

STATE INSTITUTION «INSTITUTE OF PEDIATRICS, OBSTETRICS AND GYNECOLOGY NAMS UKRAINE» Publishing house «Expert Ltd»

Qualified by the Higher Attestation Commission of Ukraine, the Order of the Presidium HAC of Ukraine 1-05/4 from 26.05.2010 Mailing address: Kiev-210, POB 32, 04210, Ukraine, post box 32, LLC «Expert Ltd», «Perinatology and Pediatrics»

E-mail: pediatr@med-expert.com.ua

http://medexpert.org.ua

Certificate of State Registration КВ 15780-4252 ПР from 27.10.2009 y., Published since $1999 \mathrm{y}$

Publishing frequency -4 Times /Year

Recommended by the Academic Council SD «Institute of Pediatrics, Obstetrics and Gynecology,

Medical Sciences of Ukraine» Protocol № 6 від 24.06.2015 p. Passed for printing 26.06.2015 p.

Format 60x90/8. Offset paper. Conventional printed sheet. 13,95. Total circulation is 8000 copies. Ord. №26.06/01 from 26.06.2015

Printed in the «Aurora-print» printing house

5, Prichalnava Str., Kiev, tel. (044) 550-52-44

Subscribe to «Perinatology and Pediatrics» journal you can at every post office Subscription index 22811

All articles reviewed. Total or partial copy of materials published in this publication at any way is available only by the letter of permission of the journal staff.

Advertiser is responsible for the content of advertising materials.

(CSU «Institute of Pediatrics, Obstetrics and Gynecology, NAMS of Ukraine», 2015 (C) Publishing house «Expert Ltd», 2015 


\section{ПЕРИНАТОЛОГИЯ И ПЕДИАТРИЯ}

Научно-практический журнал

ПЕРИНАТОЛОГІЯ ТА ПЕДІАТРІЯ

Науково-практичний журнал

\section{PERINATOLOGY AND PEDIATRICS}

Scientific and Practical journal

\section{2 (62) 2015}

СОАЕРЖАНИЕ

\section{ВНИМАНИЮ АВТОРОВ}

В начале пути: роль DOI (digital object identifier) в повышении индексов цитирования ученых

\section{СОБЫТИЯ}

\section{Сергей Гордиенко}

Открытие нового завода “БИОФАРМА» яркий пример для развития экономики Украины

\section{АКТУАЛЬНЫЕ ВОПРОСЫ ПЕРИНАТОЛОГИИ И НЕОНАТОЛОГИИ}

Деменіна Н.К., Єщенко О.І., Іщенко Г.І., Мілєвський О.В.

Вплив пробіотиків на стан плацентарного бар'єру у вагітних із хронічним пієлонефритом

Лукьянова И.С., Труба Я.П.,

Медведенко Г.Ф., Жадан Е.Д., Иванова Л.А.

Аномалии дуги аорты:

проблемы пренатальной

и постнатальной тактики

\section{ПРЕ- И ПЕРИНАТАЛЬНАЯ ДИАГНОСТИКА}

Гордієнко І.Ю., Нікітчина Т.В., Ващенко О.О., Тарапурова О.М., Величко А.В., Раченко К.В. Характеристика кількісних змін статевих хромосом у плодів жінок групи високого ризику

\section{CONTENTS}

\section{TO AUTHORS ATTENTION}

6 In the beginning of the path : the role of DOI (digital object identifier) to increase the citation indices of the scientists

\section{EVENTS}

10 Sergey Gordienko Opening of the new factory "BIOFARMA" as a vivid example for the development of the economy in Ukraine

\section{ACTUAL QUESTIONS OF PERINATOLOGY AND NEONATOLOGY}

12 Demenina N.K., Yeschenko Y.I., Ischenko H.I., Milievskyi O.V.

The effect of probiotics on the state of placental barrier in pregnant women with chronic pyelonephritis

16 Lukianova I.S., Truba Y.P., Medvedenko G.F., Zhadan O.D., Ivanova L.A. Congenital anomalies of the aortic arch: perinatal management

\section{PRE- AND PERINATAL DIAGNOSTIC}

Gordienko I.Yu., Nikitchina T.V., Vaschenko O.O., Tarapurova O.M., Velychko A.V., Rachenko K.V. Characteristics of quantitative changes of sex chromosomes in fetuses of high-risk pregnant women 
Жабченко І.А., Яремко Г.Є.,

Ліщенко І.С., Дзюба О.М., Коваленко Т.М.

Ехографічні особливості фетоплацентарного комплексу жінок із переношеною та пролонгованою вагітністю

\section{ВНУТРИУТРОБНЫЕ ИНФЕКЦИИ}

Редько І.І.

Клініко-імунологічні особливості перебігу внутрішньоутробних вірусних інфекцій у новонароджених

\section{ПРЕГРАВИДАРНАЯ ПОДГОТОВКА}

Подольський В.В., Каграманян А.Л., Подольський Вл.В.

Клініко-епідеміологічна та соціологічна характеристика жінок фертильного віку з порушеннями репродуктивного здоров'я

\section{АКТУАЛЬНЫЕ ВОПРОСЫ ПЕДИАТРИИ}

Березенко В.С., Царьова О.В.

Клініко-параклінічні аспекти перебігу хронічного вірусного гепатиту C у дитячому віці

Дудник В.М., Король Т.Г.

Інструментальні маркери ендотеліальної дисфункції при пурпурі Шенлейн-Геноха в дітей

Левадна Л.О.

До проблеми прорізування зубів у дітей

\section{ЗАБОЛЕВАНИЯ ВЕРХНИХ И НИХНИХ ДЫХАТЕЛЬНЫХ ПУТЕИ}

\section{Квашніна Л.В., Родіонов В.П.}

Клінічний досвід використання препарату «Фурасол" (обполіскувач, порошок) виробництва АT «Олайнфарм/JSC "Olainfarm" " (Латвія) в лікуванні загострень хронічного тонзиліту та/або фарингіту в дітей

Сорочан О.П., Вороньжев І.О., Крамний І.О. Променеві та морфоклінічні аспекти діагностики пневмоній та їх ускладнень у новонароджених з малою масою тіла (огляд літератури)
25 Zhabchenko I.A., Yaremko A.E., Lischenko I.S., Dziuba E.N., Kovalenko T.N. Echographic features fetoplacental complex of women with post-term pregnancy, and prolonged

\section{INTRAUTERINE INFECTION}

29 Redko I.I.

Clinico-immunological characteristics of the course congenital viral infections in newborns

\section{PREGRAVID PREPARATION}

32 Podolsky V.V., Ghahramanyan A.L., Podolsky VI.V.

Clinico-epidemiological and sociological characteristics of women of childbearing age with impaired reproductive health

\section{ACTUAL QUESTIONS OF PEDIATRICS}

38 Tsaryova O.V., Berezenko V.S

Clinical and paraclinical aspects

of chronic hepatitis $\mathbf{C}$ in children

43 Dudnyk V.M., Korol T.G. Instumentalni markers of endothelial dysfunction in Schonlein-Henoch purpura in children

47 Levadna L.O

The problem of teeth eruption

\section{THE UPPER AND LOWER RESPIRATORY TRACT DISEASES}

52 Kvashnina L.V., Rodionov V.P.

The clinical experience with the drug «Furasol» (powder for solution for rinsing) production of JSC "Olainfarm / JSC "Olainfarm"” (Latvia) in the treatment of exacerbations of chronic tonsillitis and / or pharyngitis in children

56 Sorochan O.P., Voron'zev I.O., Kramniy I.O. Radiologcal, morphological and clinical data in diagnostics pneumonia and it complications in low birth weight infants 


\section{КАРДИОРЕВМАТОЛОГИЯ}

Дудник В.М., Зборовська О.О.

Предиктори розвитку серцевої недостатності в дітей з вродженими вадами серця після оперативної корекції

Ніколаєнко В.Б., Полук Т.А., Омельченкоа Л.І. Особливості дебюту ювенільного псоріатичного артриту (клінічний випадок)

\section{ГАСТРОЭНТЕРОЛОГИЯ}

Сокольник С.O.

Значення генеалогічного анамнезу в розвитку шлунково-кишкових кровотеч у дітей, хворих на виразкову хворобу

Тяжка О.В., Горобець А.О., Климчук В.В., Т.А. Богданова, Л.О. Левадна

Непереносимість глютена без целіакії:

чи є привід замислитися?

\section{НЕФРОЛОГИЯ}

Тарасюк Б.А., Андрущенко И.В., Лукьянова И.С.

Ультразвуковые проявления аутосомно-рециссивной поликистозной болезни почек у детей

\section{ДЕТСКАЯ ГИНЕКОЛОГИЯ}

Дынник B.A.

Характеристика клинического течения аномальных маточных кровотечений пубертатного периода в зависимости от дебюта заболевания

\section{МАТЕРИАЛЫ КОНФЕРЕНЦИИ}

Аряєв М.Л., Васильченко Л.В. Мерікова Н.Л., Шевченко І.М.

Клініко-біохімічне обґрунтування

застосування ентерособції

в новонароджених з гемолітичною хворобою

Ізюмець С.О., Галактіонова І.В., Ізюмець О.І. Перинатальна патологія у формуванні атлантичної хвороби новонароджених

Ізюмець С.О., Ізюмець О.І.,

Галактіонова І.В., Мурашко Т.В.

Роль перинатальної патології

у виникненні аспіраційного синдрому в новонароджених, його діагностика

Оніськова О.В., Ющенко Л.О., Коваленко Г.О. Ранній початок статевого життя в підлітків: причини та наслідки

\section{CARDIORHEUMATOLOGY} Predictors of the development of the heart failure in children with congenital heart defects after the surgical correction

66 Nikolaenko V.B., Poluk T.A., Omelchenko L.I. Features of juvenile psoriatic arthritis debut

\section{GASTROENTEROLOGY}

71 Sokolnyk S.O.

The value of the genealogical history in the development of gastrointestinal bleeding in children with peptic ulcer

74 Tiazhka O.V., Gorobets A.O., Klimchuck V.V., Bogdanova T.A., Levadna L.O.

Non-celiac gluten sensitivity: is there any reason to worry about?

\section{NEPHROLOGY}

77 Tarasyuk B.A., Andruschenko I.V., Lukyanova I.S

The ultrasound signs

of autosomic recessive policystic kidney disease in children

\section{CHILDREN'S GYNECOLOGY}

81 Dynnik V.A.

Characteristics of clinical flow of anomalous uterine bleeding pubertal period depending on the onset of the disease

\section{CONFERENCE MATERIALS}

86 Aryayev M.L., Vasil'chenko L.V. Merikova N.L., Shevchenko I.M.

Clinical and biochemical enterosorption application among the newborns with hemolytic disease

90 Izumec S.O., Galaktionova I.V., Izumec O.I. Perinatal pathology as the base for atlantic disease of neonates

94 Izumec S.O., Izumec O.I., Galaktionova I.V., Murashko T.V. The role of perinatal pathology as the origin of occurrence of aspiration syndrome among neonates, its diagnostics

98 Oniskova O.V., Yushchenko L.A., Kovalenko S.A. Early onset of sexual activity among adolescents: Causes and Consequences 


\title{
ГРУППА КОМПАНИЙ «МедЭксперт»
}

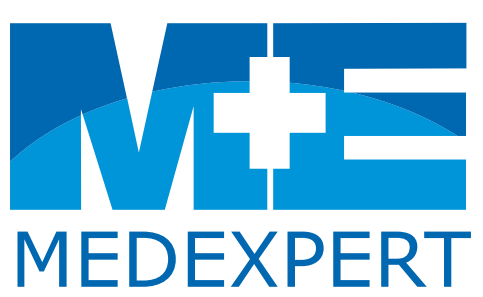

\author{
группа компаний \\ МЕД-ЭКСПЕРТ \\ медицинские издания, \\ конференции и семинары, \\ маркетинговые исследования
}

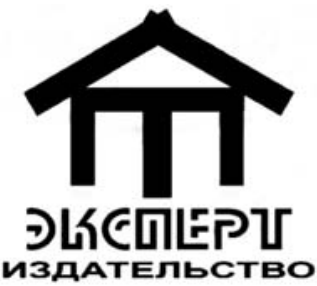

\section{В начале пути: роль DOI (digital object identifier) в повышении индексов цитирования ученых}

С истема DOI - это механизм, который обеспечивает работу постоянных гиперссылок, связанных ет поиск источников научной литературы, а также расширяет возможности оценки через индексы цитирования публикационной активности ученых (H-index) и издательств (Impact Factor).

Основной задачей CrossRef является организация доступа пользователей к первичным публикациям, содержащим научный контент, и содействие коллективной работе издателей. CrossRef использует технологию открытых стандартов системы DOI, и является также официальным регистрационным агентством DOI для образовательных и профессиональных научных публикаций. Система DOI обеспечивает структуру для постоянной идентификации, управления интеллектуальным контентом, управления метаданными, связи пользователей с поставщиками контента.

В настоящее время функциональность системы DOI довольно глубоко интегрирована в информационные системы, которые являются носителями научно-информационных ресурсов. За последние 15 лет система получила довольно широкое распространение во многих сферах информационной деятельности, но более всего укрепилась в практике научно-издательской деятельности в Северной Америке, на Европейском континенте, в некоторых странах Азии. Известные издательства, такие, как Elsevier, Karger, Blackwell и многие другие по всему миру активно используют в работе своих электронных библиотек систему DOI, которая выполняет важную роль в реализации существующего наукометрического обеспечения.

В Украине системой универсального идентификатора цифрового объекта (DOI) пользуются лишь несколько журналов, в основном те, которые издаются иностранными издательствами за рубежом. Издательство «Группа компаний «МедЭксперт», которое зарегистрировано в Украине и издает отечественные медицинские журналы - «Современная педиатрия», «Перинатология и педиатрия», «Здоровье женщины», «Социальная педиатрия и реабилитология», «Україна. Здоров'я нації», «Международный журнал реабилитация и паллиативная медицина», - первым, с 2014 года, начало использовать систему DOI для индексирования научных медицинских статей и других информационных объектов.

Возможность присвоения DOI, также как и регистрация в наукометрических базах данных требует выполнения определенных требований, которое завершается заключением договора о сотрудничестве с агентством CrossRef или ассоцированными с CrossRef организациями, а также вступлением в Международную организацию издателей научной литературы (PILA).

Использование DOI помогает в направлении увеличения цитирования научных изданий и повышению рейтинга журналов. Сисема CrossRef, помимо регистрации DOI, предлагает ряд услуг издательствам, одной из таких услуг является Cyted-by linking (связанное цитирование). По договору с CrossRef, после размещения на сайте основных метаданных статьи, издательство размещает также списки литературы данной статьи. При использовании системы индексации DOI становится доступной информация о тех, кто и где процитировал данную статью. Таким образом, данная услуга способствует повышению рейтинга журнала/издательства, увеличению цитирования отечественных изданий. 
Структурно, идентификатор DOI представляет собой алфавитно-цифровую строку, присвоенную цифровому объекту (книга, статья), и состоящую из трех компонентов: директория (http://dx.doi.org), префикс, суффикс, которые разделяются символом пунктуации «косая черта». В результате вступления в Международную организацию издателей научной литературы (PILA) и регистрации в CrossRef, издательству «МедЭксперт» был присвоен префикс 10.15574/, основная часть индекса DOI, которая является уникальной и соответствует названию издателя. DOI директория может не указываться в печатной версии статьи.

В дальнейшей своей работе издатель присваивает суффикс каждой конкретной публикации или ее части. Формат суффикса определяет издатель, при этом можно использовать буквы латинского алфавита, цифры и определенные символы. Полный индекс DOI статьи издательства «МедЭкперт», например, в журнале «Перинатология и педиатрия» выглядит DOI: 10.15574/PP.2014.58.34.

Процесс индексации DOI издания происходит следующим образом. После того, как статьи приняты в печать и подготовлена рукопись со всеми метаданными статей (название, фамилии авторов, место работы, год, том, номер, страницы), создается веб-страница выпуска журнала, которая состоит (упрощенная форма) из содержания, резюме с метаданными и ссылками на литературные источники и ссылка на полный текст статьи. Далее издатель присваивает DOI каждой статье.

Связь с исходным документом при наличии идентификатора DOI осуществляется через службу распределения (HTTP-прокси-сервер DOI - http://dx.doi.org/.), которая направляет запросы в зависимости от тех данных, которые содержатся в её базе данных, т.е. к реальному адресу URL, по которому доступен цитируемый документ. Роль издательства заключается в том, что метаданные исходной статьи (ISSN, название и аббревиатура журнала, исходные данные статьи: название на английском (и языке оригинала, если статья не на английском), фамилии и инициалы авторов, места работы авторов, том, номер, первую и последнюю страницу, дату публикации), URL статьи и индекс DOI направляются в CrossRef или ассоциированные агентства для регистрации. Эта триада будет хранить информацию как карточка в библиотечном каталоге.

Внедрение системы DOI в издательскую деятельность повышает публикационную активности изданий, увеличивает доступность научных публикаций за пределами Украины и расширяет возможности быть представленными в известных наукометрических базах данных. Ценность идентификатора DOI для пользователей заключается в том, что его использование в любое время обеспечивает быстрый поиск научной статьи, книги без необходимости проведения поиска на сайтах журналов или поисковых систем.

Многие известные наукометрические базы данных, как Scopus, Web of Science, Google Scholar и др. pacполагают техническими возможностями автоматического анализа активности издательств, их издательской продукции, количественной оценки деятельности различных научных организаций и отдельных исследователей. Идентификатор цифровых объектов DOI является необходимым звеном доступности для анализа научной продукции, который осуществляется информационно-аналитическими системами этих наукометрических баз данных.

Таким образом, использование DOI позволит более широко представлять отечественные научные достижения мировой науке, улучшит обмен научной информацией между учеными, будет способствовать повышению рейтинга отечественных научных журналов за рубежом, а также индексов цитирования ученых Украины.

Заведующий научным отделением медико-информационных технологий в педиатрии, акушерстве и гинекологии ДУ «ИПАГ НАМН Украинь Маруико Р.В. 


\section{Сокровища современного мира XXI века или вечные ценности, которые не знают границ и не поАвАवстны времени}

Окиньте мысленным взором свою жизнь. Попробуйте определить свои главные ценности в жизни... Что приходит Вам на ум? Счастье, любовь, патриотизм, дети, храбрость, семья, дом, здоровье, вдохновение, дружба, успех, карьера, радость - скажите Вы. Но этот список может продолжаться до бесконечности, ведь каждая ценность особенна и дорога для каждого человека по-своему, и далеко не все понимают их значимость в жизни. Значимость ценностей определяет сам человек своим к ним отношением. Переоценить вечные ценности невозможно, кроме этого, их ценность не меняется ни при каких обстоятельствах. Важно ценить и понимать общую, безличную значимость ценностей. Именно поэтому Украинским Рейтинговым Агентством был создан Проект «Вечные ценности», где мы пытаемся разобраться, что же является для украинцев та бесценная, истинная и неподвластная времени - вечная ценность.

Первым, пилотным этапом Проекта «Вечные ценности» было исследование о счастье. Мы узнали, в чем же, все таки, секрет счастья в наше нелегкое время, когда в нашей стране так много беспокойства и смятения, раздоров, ссор, непонимания.

Вторым этапом было исследование о любви. Любовь - это то, что всем знакомо: она исцеляет больных, делает несчастных счастливыми, наделяет человека удивительной способностью совершать чудеса и подвиги. Любовь не нужно искать далеко, она живет совсем рядом с нами, иногда яркая и неудержимая, а иногда светлая и тихая.

Третий этап «Вечных ценностей» стартовал с исследования о патриотизме: быть патриотом - не значит ненавидеть. Это значит любить. С гордостью о патриотизме или как украинцы понимают отчизнолюбие.

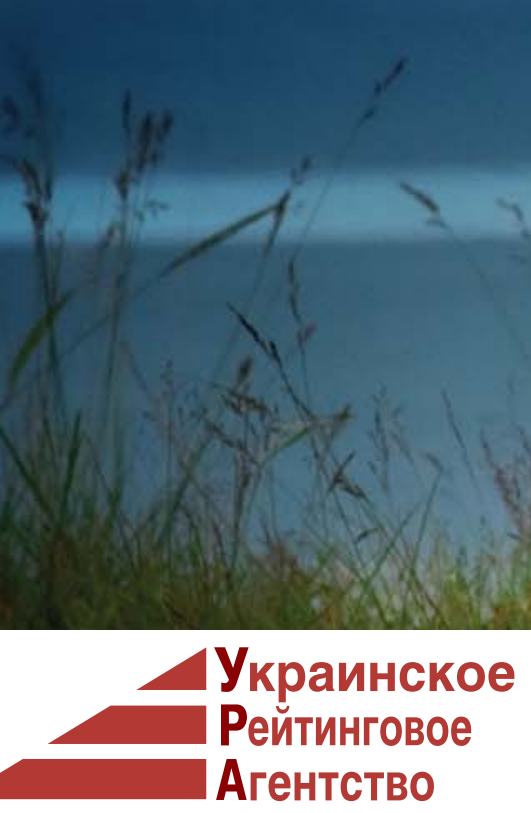




\section{Слелите за нашими новостями, кажАЫЙ этап уникаАьный}

И напоследок. Не ждите, когда окончите институт или школу, когда родятся дети. Хватит ожидать, когда начнете работать, когда уйдете на пенсию, когда женитесь или разведетесь. Не ждите вечера пятницы, утра понедельника, покупки новой машины, квартиры или дома. Не ждите весны, лета, осени, зимы. Минуты счастья - драгоценны, минуты любви - бесценны. Работайте - не только ради денег, любите - не в ожидании расставаний. Всегда улыбайтесь - не обращая внимания на взоры. Самая ужасная ошибка, которую вы можете совершить - это всю жизнь гнаться за целями, не замечая, как мимо вас пробегает ваша жизнь, цените здесь и сейчас, ведь завтра может и не наступить... Берегите в себе человека - это самая важная ценность в современном мире.

Надеемся, что результаты наших исследования заставят кого-то задуматься и переосмыслить свою жизнь и свои поступки, кого-то, наоборот, убедят в правильности своих действий, а кому-то станут «рецептом», как достичь гармонии с собой и окружающим миром.

\section{Значение ценности переживается,}

\section{смыс^ - осознается.}

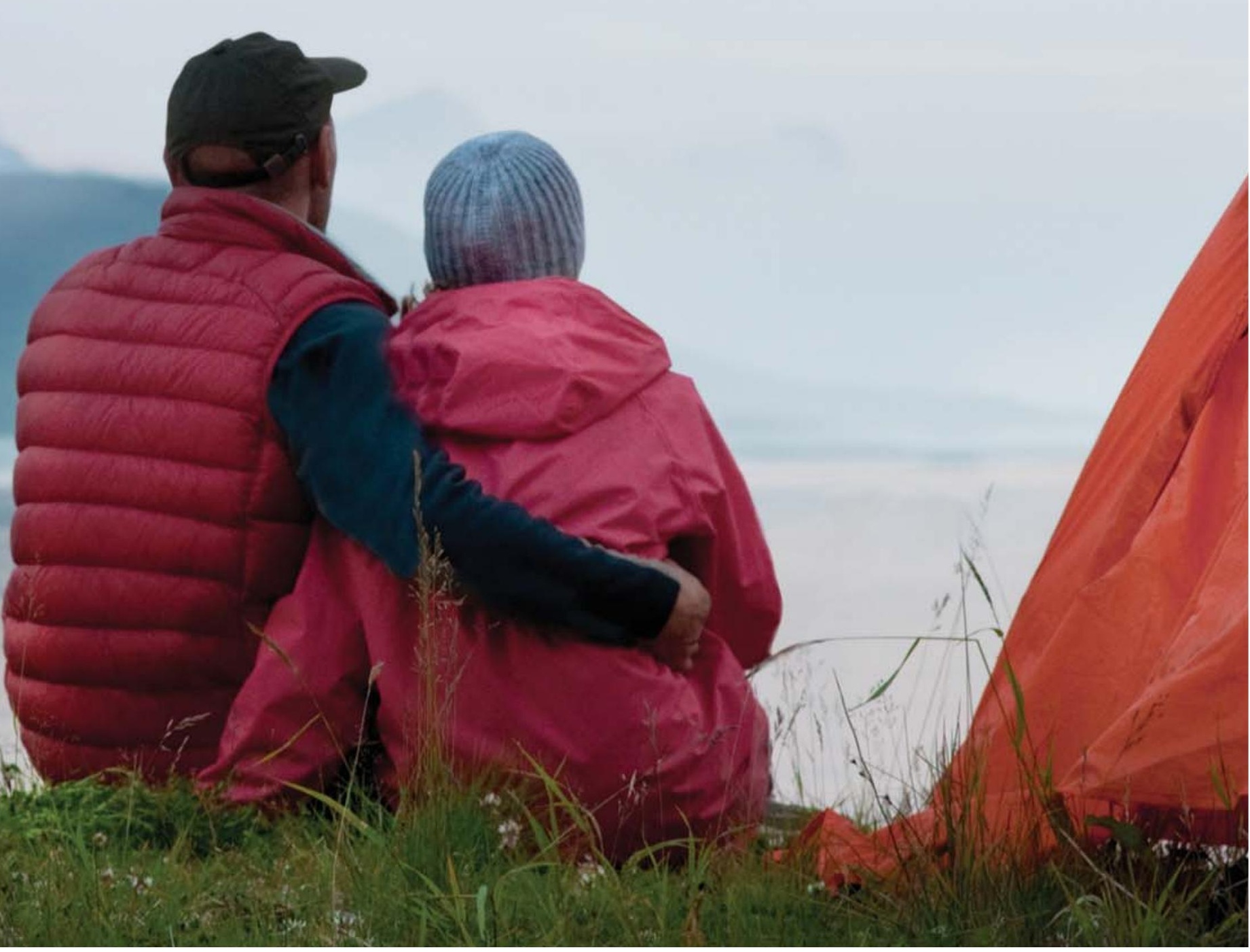




\section{Открытие нового завода «БИОФАРМА» - яркий пример развития экономики Украины}

Сергей Гордиенко

16 июня 2015 г. в г. Белая Церковь в присутствии Министра здравоохранения Украины Александра Квиташвили, его первого заместителя Александры Павленко, посла Канады Романа Ващука, представителей посольств США, Австралии, Италии и других стран, главы Киевской областной государственной администрации Владимира Шандры и представителей международных финансовых учреждений торжественно открылся новейший биофармацевтический научно-производственный комплекс «Биофарма». Во время мероприятия руководство компании передало Министру здравоохранения Украины Александру Квиташвили медикаменты производства «Биофарма» общей стоимостью 1 миллион гривен для обеспечения потребностей Министерства обороны Украины, которые будут использованы для лечения пострадавших в АТО бойцов. Также состоялась церемония закладки первого камня (капсулы) в основание будущего предприятия по производству препаратов из плазмы донорской крови человека, которое станет крупнейшим на постсоветском пространстве и в Восточной Европе. Инвесторы и акционеры предприятия, среди которых украинские бизнесмены Константин Ефименко и Василий Хмельницкий, фонд Horizon Capital и банк FMO реализовали наиболее масштабный инвестиционный проект в биофармацевтической отрасли Украины.

В настоящий момент компания «Биофарма» выпускает 130 препаратов 11 фармакологических групп и является производителем №1 в таких сегментах украинского фармацевтического рынка, как препараты плазмы донорской крови, рекомбинатные препараты, пробиотики и так называемые «органопрепараты».

Выступая на торжественной церемонии открытия нового завода, Министр здравоохранения Украины Александр Квиташвили подчеркнул важность момента для Украины: «Для меня огромная честь быть здесь, и я знаю, что за 40 миллионами инвестиций последует еще больше инвестиций. Мы хотим, чтобы фармсектор развивался, был конкурентоспособным, и чтобы мы работали не только с зарубежными компаниями, но и наши украинские компании выходили на мировые рынки, и это будет важным моментом для развития экономики Украины. Я - человек, который всю жизнь старался помочь частному бизнесу развиваться, и для меня такая инвестиция как раз и есть показателем нормально развивающегося фармсектора. Каждая инвестиция - это свидетельство веры в Украину, в ее будущее, в развитие экономики. Это новые рабочие места и тем самым инвестиция в социальную защиту». Александр Квиташвили поблагодарил инвесторов компании «Биофарма» и призвал других последовать их примеру. Также он зачитал приветственные слова Премьер-министра Украины Арсения Яценюка.

Председатель правления ЧАО «Биофарма» Александр Маковский отметил, что «новый НПК «Биофарма» - это мировое качество лекарственных средств в Украине. Более того - это первое фармацевтическое производство, построенное в стране «с нуля» за последние 100 лет. И это самая большая за всю историю независимой Украины иностранная инвестиция в фармацевтическую отрасль. Можно сказать, что это новый этап в развитии отечественной фармацевтической отрасли по уровню технологий, условиям труда, экологическим стандартам».

Глава Киевской областной государственной администрации Владимир Шандра указал на важность открытия завода для г. Белая Церковь, поскольку создаются новые рабочие места, увеличивается объем поступающих в бюджет города налогов, развивается инфраструктура. Особо он подчеркнул, что новейшее оборудование завода построено по энергоэффективным технологиям.

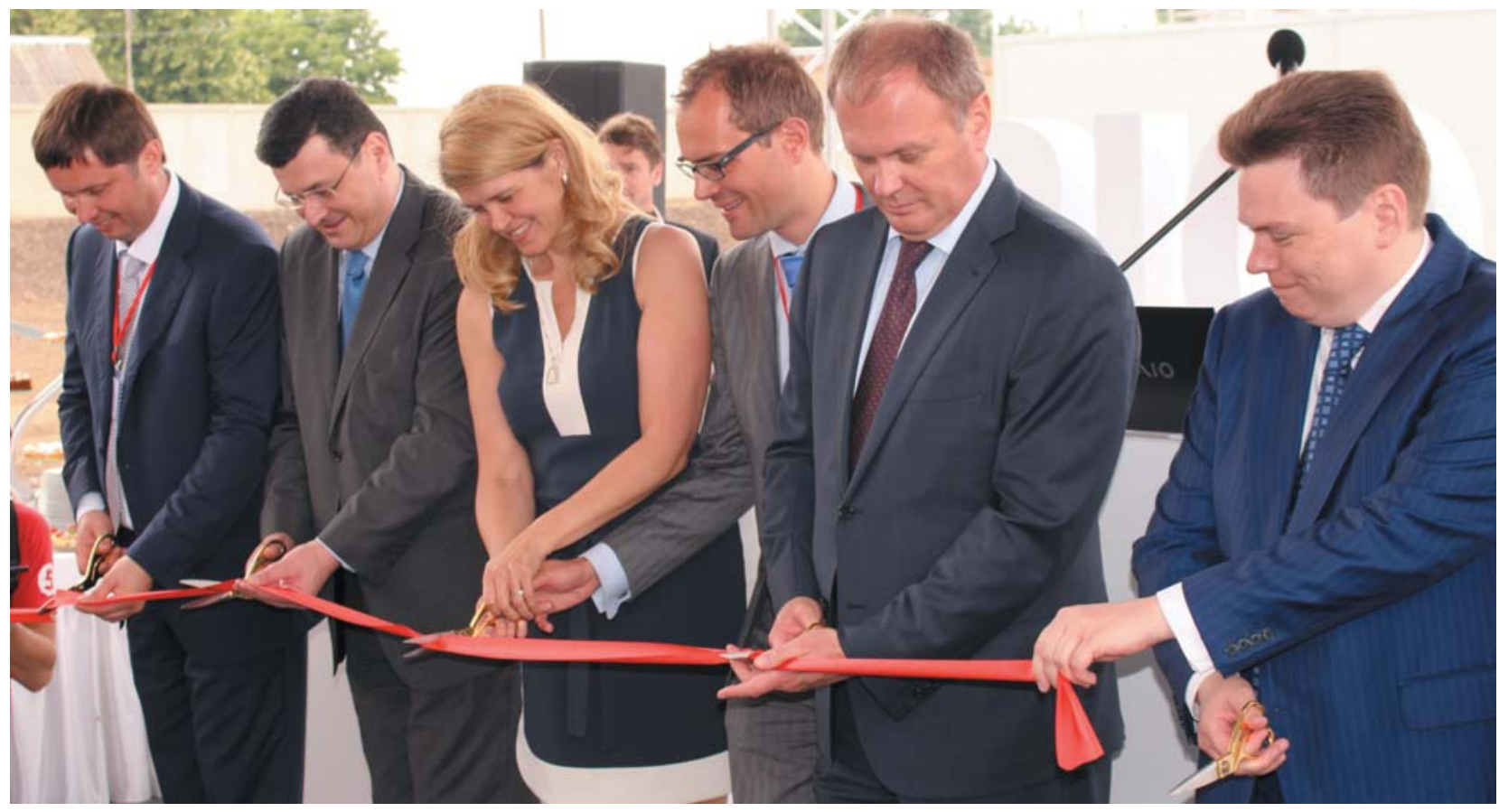


Председатель наблюдательного совета компании «Биофарма» Константин Ефименко отметил: «Мы реализуем наиболее масштабный инвестиционный проект в фармацевтической отрасли Украины. Открытие нового производственного комплекса сегодня является действительно неординарным событием, а также признаком инвестиционной привлекательности Украины и поводом для дальнейшего увеличения притока иностранных инвестиций. С запуском этого предприятия «Биофарма» станет лидером в сфере эффективных и современных технологий производства в Украине, создаст около 300 рабочих мест и расширит возможности для дальнейшего роста экспорта и поступления валютных средств в Украину. Наш завод работает в соответствии с национальными и международными стандартами производства лекарственных средств».

Советник Посла США в Украине по экономическим вопросам Вильям Лейтинен подчеркнул: «Это мероприятие демонстрирует, что инвестиции продолжают приходить в Украину в эти нелегкие времена реформ, и что украинские, американские и голландские инвесторы поддерживают Украину и верят в ее экономический потенциал и заинтересованы в ее экономическом развитии».

Олена Кошарна, учредитель и главный исполнительный директор Horizon Capital, сказала: «Эта инвестиция подтверждает нашу уверенность в украинской фармацевтической отрасли и веру в Украину. Я хочу поблагодарить управленческую команду компании за лидерство и наших партнеров за сотрудничество. Мы уверены, что благодаря высокому качеству продукции и увеличению производственных мощностей вдвое в результате запуска нового завода «Биофарма» достигнет еще больших успехов. Мы выражаем компании наше почтение за успешную деятельность на отечественном рынке, а также за экспорт в более чем 10 стран мира, что является свидетельством наивысшего качества продукции компании. Мы также гордимся сотрудничеством с FMO и нашими украинскими партнерами, которое дало нам возможность инвестировать реальные средства и создать высокотехнологические рабочие места, в то время как прямые иностранные инвестиции и новые возможности трудоустройства крайне необходимы для Украины. Больше всего мы гордимся тем, что «Биофарма» производит препараты плазмы крови для людей, которые получили тяжелые травмы и ожоги, которые борются с такими болезнями, как рак, для беременных женщин и других, кто нуждается в этой помощи более всего. Помимо производства жизненно необходимых лекарственных препаратов, «Биофарма» также поддерживает украинских военных, которые получили ранение во время АТО».

Идсерт Боерсма, директор по юридическим вопросам FMO, так прокомментировал это событие: «Мы очень довольны инвестицией в новое современное производственное предприятие «Биофарма» и уверены, что жизненно необходимые медицинские препараты станут более доступными для украинцев, а высокое качество обеспечит их выход на новые международные рынки и основу для еще большего роста».

Современный биофармацевтический НПК «Биофарма» был построен на средства украинских и иностранных

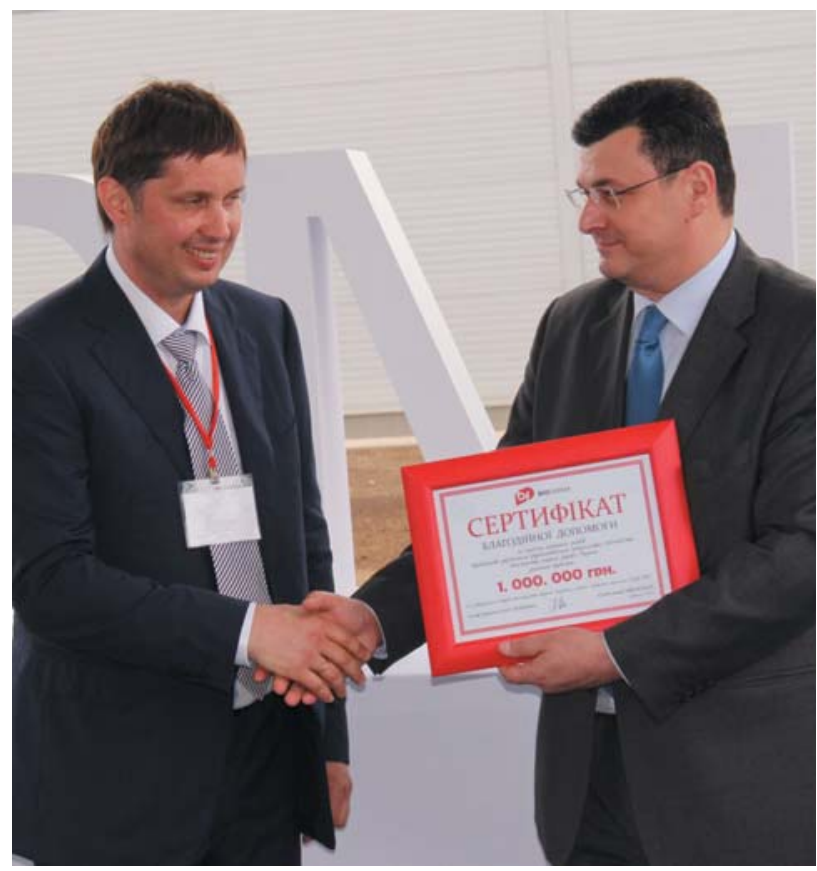

инвесторов (американской компании Horizon Capital и голландского банка развития FMO) за рекордно короткий срок - 1,3 года. Завод был спроектирован Linde Engineering (Германия), международной инжиниринговой компанией с большим опытом работы в фармацевтической отрасли, и соответствует современным нормативным требованиям и требованиям GMP (Good Manufacturing Practice).

Начало строительства второй очереди завода (по переработке плазмы крови) запланировано на август этого года. Инвестиции составят $\$ 35$ млн. На протяжении трехпяти лет будет построен завод производственной мощностью 320 тонн, с поочередным запуском 160 и 320 тонн переработки. Проект нового завода-фракционатора разработан итальянской компанией Foster Wheeler. Новый завод значительно расширит существующие производственные мощности компании по переработке плазмы, которые на сегодня составляют до 90 тонн в год.

Строительство второй очереди завода позволит на 100\% обеспечить население Украины отечественными препаратами из плазмы крови, которые не уступают по качеству импортным аналогам и являются более доступными по цене. Более того, это будет стимулировать проведение реформ, в частности активное развитие службы крови в Украине. Завод будет производить такие лекарственные средства, как иммуноглобулин, альбумин и фактор VIII. Производство препаратов будет осуществляться по собственной технологии, которая была разработана научной лабораторией компании «Биофарма» и успешно прошла экспертизу специализированного немецкого института вакцин и биологических лекарственных средств им. Пауля Эрлиха.

Таким образом, «Биофарма» продолжает инвестировать в развитие экономики Украины и фармацевтической отрасли в частности, создавая новые рабочие места и выпуская продукцию, которая может достойно конкурировать на украинском и международном рынках. 


\title{
УдК 618.36:616.61-002.3-08:611-013.85
}

\section{Н.К. Деменіна, О.І. Єщенко, Г.І. Іщенко, О.В. Мілєвський Вплив пробіотиків на стан плацентарного бар'єру у вагітних із хронічним пієлонефритом}

\author{
ДУ «Інститут педіатрії, акушерства і гінекології НАМН України», м. Київ, Україна
}

PERINATOLOGIYA I PEDIATRIYA.2015.2(62):12-15; doi10.15574/PP.2015.62.12

Мета - вивчити морфологічні особливості плаценти у вагітних із хронічним пієлонефритом.

Пацієнти та методи. Для вивчення морфологічних особливостей плаценти досліджено такі групи: 1-а група - плаценти від жінок, хворих на хронічний пієлонесрит, які отримували курс лікування цієї хвороби відповідно до діючих рекомендацій - 70 жінок; 2-а група — плаценти жінок із хронічним пієлонефритом, яким додатково проводилося відновлення мікробіоценозу пологових шляхів та кишечнику пробіотичною композицією живих штамів L. plantarum BКПМ В-5002 і Str. Salivarius subsp. thermophilus ВКПМ В-3813 у співвідношенні 8:2, у дозі 108-109 КУ0/мл напередодні пологів - 50 жінок; 3-я група (контроль) - плаценти здорових жінок із фрізіологічним перебігом вагітності. Для вивчення морфологічних особливостей плаценти в обстежених жінок використано такі методи: органометричний, макроскопічний, загальногістологічний.

Результати. У групі жінок із хронічним пієлонефритом (1-а група), за сукупністю органометричних, макроскопічних та гістологічних особливостей плацент, у 60\% випадків відмічено плацентарну дисфункцію вогнищевого характеру з елементами незрілості по типу проміжних диференційованих ворсин і дисоційованого розвитку ворсин на фоні компенсаторних реакцій як на клітинному, так і на тканинному рівні, середнього ступеня виразності. У 36\% плацент виявлено вогнищеві зміни децидуальної оболонки у вигляді набряку, повнокров'я судин та децидуїту, явища парієнтального мембраніту в плідних оболонках та інтервілузіту в міжворсинчастому просторі.

У групі жінок із хронічним пієлонефритом (2-а група), які додатково отримували пробіотичну композицію, в 60\% плацент не відмічено запальних змін вогнищевого характеру, лише в 34\% плацент виявлено вогнища запальної інфільтрації в децидуальній оболонці та в міжворсинчастому просторі під децидуальною оболонкою, а в 16\% плацент — тільки в децидуальній оболонці.

Висновки. У плацентах від жінок із хронічним пієлонефритом у 60\% відмічено вогнищеві прояви плацентарної дисфункції на фроні запальних змін у міжворсинчастому просторі, децидуальній та плідній оболонках. При застосуванні пробіотичної композиції прояви плацентарної диссункції виявлено в 40\% на фроні зменшення запальних змін у децидуальній оболонці і мідворсинчастому просторі. у 16\% плацент встановлено тільки вогнищеві зміни запального характеру в децидуальній оболонці (децидуїт).

Ключові слова: хронічний пієлонефрит, вагітність, плацента.

\section{Вступ}

Проблема пієлонефритів у вагітних, незважаючи на значну увагу до неї науковців і практичних лікарів, посідає провідне місце серед інших ускладнень гестаційного періоду як за частотою розвитку, так і за тяжкістю наслідків.

Дослідження, проведені в останнє десятиріччя, дали змогу розширити уяву про механізми патогенезу хронічного панкреатиту (ХП) і завдяки цьому розробити нові тактичні і стратегічні принципи лікування даної патології. Поряд з успіхами, досягненими у вивченні етіології, патогенезу, діагностики і терапії ХП, залишаються не до кінця з'ясованими питання про запобігання гнійно-запальним захворюванням пуерперію у хворих на ХП $[2,7,10]$.

Актуальність проблеми полягає в тому, що інфекційно-запальні процеси в нирках можуть ініціювати етіопатогенетичні механізми виникнення низки ускладнень вагітності, пологів та післяпологового періоду: мимовільного викидня, передчасних пологів, передчасного вилиття навколоплодових вод, народження дітей з низькою масою тіла, внутрішньоутробного інфікування плода, гнійно-запальних захворювань пуерперію [4, 5, 9].

Залучення в інфекційний процес плаценти та плодових оболонок $є$ важливим етіологічним чинником вищеперерахованих ускладнень $[1,3,8]$.

Суттєву роль у патогенезі післяпологових гнійно-запальних захворювань у жінок з ХП відіграє мікробіологічний фактор. У літературі простежується те, що у вагітних, хворих на ХП, виявляється високе бактеріальне засівання сечостатевих шляхів, часто з ідентичністю флори в сечі та піхвових виділеннях. Цей факт підтверджує літературні дані про те, що вагітні, хворі на ХП, потребують санації піхви з подальшим відновленням мікрофлори пологових шляхів [6, 11].

При фізіологічному стані взаємовідношення макроорганізму та мікрофлори мають симбіотичний характер. У вагітних, хворих на ХП, виникає порушення колонізаційної резистентності, знижується число лактобактерій, здат- них колонізувати піхву, підвищується кількість потенціально-патогенних мікроорганізмів, простежується їх транслокація до внутрішніх органів, розвиваються гнійносептичні процеси, підвищується частота переносу генів антибіотикорезистентності і патогенності між бактеріальними популяціями, ареал аеробних та анаеробних бактерій розширюється на сусідні та віддалені ділянки слизових [6].

Доведено вплив лактобацил на імунну систему. Вони обумовлюють адьювантний ефект, стимулюють міграцію моноцитів і макрофагів, активують їх фагоцитарну та ферментативну активність, а також функціональну активність поліморфноядерних лейкоцитів [11]. Усе вищезазначене обгрунтовує доцільність використання лактобактерій у складі пробіотичних препаратів для комбінованої терапії вагітних із ХП для профілактики гнійно-запальних захворювань у пуерперії.

Незважаючи на значну кількість робіт, в яких вивчався перебіг вагітності та пологів при ХП, вплив на плід і стан новонародженого; ще не з'ясовані структурнофункціональні зміни в плаценті у вагітних із ХП.

Mema роботи - вивчити морфологічні особливості плаценти у вагітних із ХП.

\section{Матеріали та методи дослідження}

Для вивчення морфологічних особливостей плаценти досліджено такі групи:

1-а група - плаценти від породіль із ХП, які отримували курс лікування з приводу основного захворювання відповідно до діючих протоколів, - 70 досліджень;

2-а група - плаценти від породіль із ХП, яким додатково проводили відновлення мікробіоценозу пологових шляхів та кишечнику пробіотичною композицією живих штамів L.plantarum ВКПМ В-5002 і Str. salivarius subsp. thermophilus ВКПМ В-3813 у співвідношенні 8:2, у дозі $10^{8}-10^{9}$ КУО/мл напередодні пологів, -50 досліджень;

3-я група - плаценти здорових породіль із фізіологічним перебігом вагітності (контроль) - 20 досліджень. 


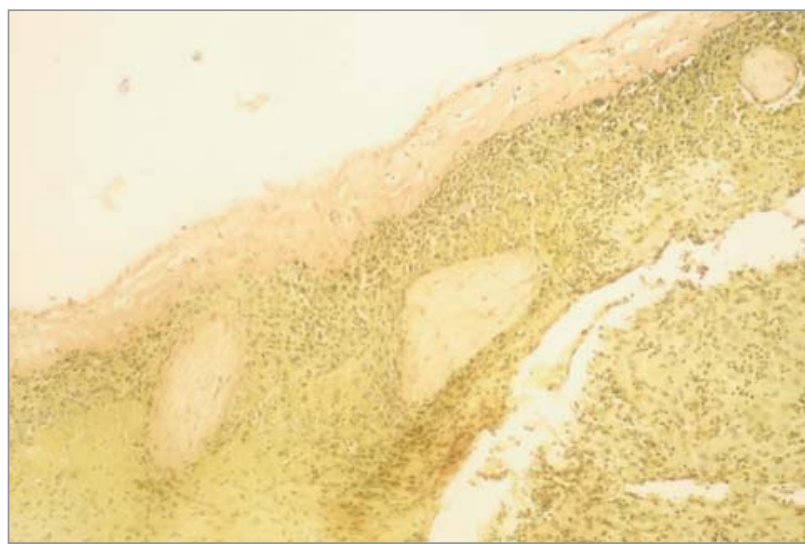

Pис. 1. Плацента жінки з хронічним пієлонефритом (1-а група дослідження). Оболонка плода. Парієтальний мембраніт. Забарвлення пікроффуксином за Ван-Гізоном. Мікрофротографрія. Ок. 10 Об. 10.

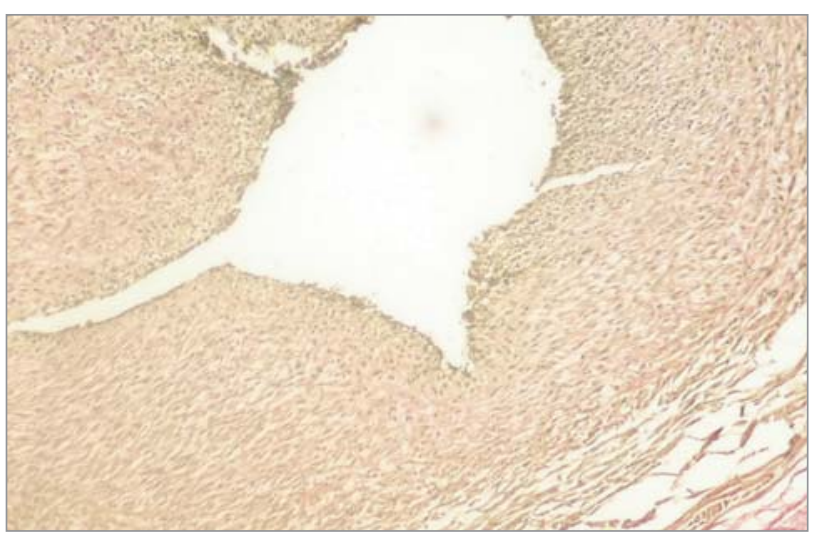

Pис. 2. Плацента жінки 3 хронічним пієлонефрритом (1-а група). Васкуліт у вені пуповини. Забарвлення пікрофруксином за Ван-Гізоном. Мікрофротографрія. Ок. 10 Об. 10.

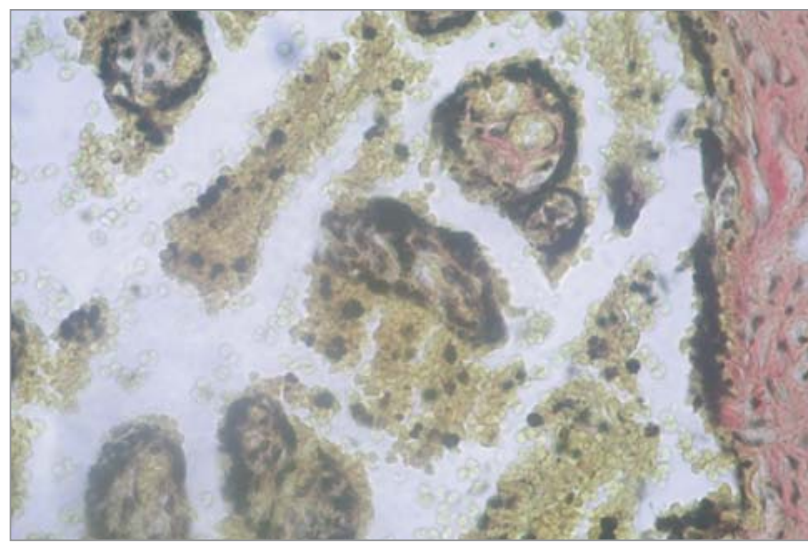

Pис. 3. Плацента жінки з хронічним панкреатитом (1-а група). Ділянка крововиливу в міжворсинчастий простір із вогнищем інтервілузіту. Забарвлення пікрофуксином за Ван-Гізоном. Мікрофротографрія. Ок. 10 Об. 20.

Для вивчення морфологічних особливостей плацент у жінок із хронічними запаленнями нирок використано такі методи:

1. Органометричний - вимірювали масу плаценти, iii розміри (максимальний та мінімальний діаметр, максимальну та мінімальну товщину), діаметр та товщину пупкового канатику.
2. Макроскопічний - визначали цілісність тканин плаценти, ії реконструкцію; вивчали форму материнської, плодової поверхні, пуповину.

3. Загальногістологічний - проводили за стандартною схемою: з фіксованої в нейтральному формаліні тканини плаценти через усю товщу вирізали 6 шматочків (2 3 краю; 2 - 3 парацентральної частини, 2 - $з$ центральної зони плаценти). Матеріал обробляли в парафіновій заливці, зрізи фарбували гематоксилін-еозином і пікрофуксином за Ван-Гізоном.

Морфологічний аналіз досліджуваних плацент проводили на підставі створеного протоколу плаценти, який включає дані органометричних, макроскопічних, мікроскопічних досліджень.

\section{Результати дослідження та їх обговорення}

Структурні особливості плацент 3-ї групи (контроль) дослідження співпадали із загальноприйнятою гістологічною нормою плаценти. Будова ворсинок у $70 \%$ спостережень відповідала гестаційному терміну 39-40 тиж., у 20\% плацент відмічалися вогнища відносної незрілості за типом дисоційованого розвитку ворсин, у 10\% - проміжних диференційованих ворсин, що компенсувалося за рахунок достатньої маси плацент і компенсаторних реакцій у вигляді ангіоматоза термінальних ворсин.

При макроскопічному дослідженні плацент від породіль 1-ї групи у більшості спостережень виявлялося зниження маси плацент $(390,0 \pm 11,7$ г) порівняно 3 контролем $(450,0 \pm 13,5$ г); плаценти мали менші розміри - 18,0х16,0 см² і товщину 1,5 см; порівняно 3 контрольною групою - розміри $21,0 \times 18,0$ см $^{2}$ та товщина 2,0-2,5 см. У 50,0\% породіль 1-ї групи плодові оболонки були набряклі, сіровато-жовтого кольору. Пупковий канатик потовщений за рахунок набряку (у 85,7\% спостережень). У 8 (11,4\%) плацентах 1-ї групи відмічався тромбоз судин, у 10 (14,3\%) - варикозне розширення вен і несправжні вузли пупковини. Плаценти були здебільшого округлої та овальної форми. Борозди - переважно різної глибини. Тканина плаценти у 85,7\% спостережень повнокровна, у 15,7\% - кровонаповнення неравномірне. У 15,7\% плацент відмічалася значна кількість інфарктів (білих), розташованих здебільшого на материнській частині плаценти. Локалізувалися інфаркти по краю плаценти, субхоріально. У 35 (50,0\%) плацентах виявлялися кісти розмірами $0,2-1,0$ см, розташовані переважно у центральних і парацентральних зонах плацентарної тканини, у товщі, і містили кров або слиз. У цілому макропатологія плацент 1-ї групи займала 10,0\% материнської поверхні.

При мікроскопічному дослідженні плацент 1-ї групи епітелій плацентарного амніона був без змін, із невеликими вогнищами запальної інфільтрації.

При дослідженні плідних оболонок у 40 плацентах 1-ї групи відмічалась вогнищева картина парієтального мембраніту. При цьому запальна інфільтрація локалізувалась у межах децидуального та цитотрофобластичного шарів плідних оболонок (рис. 1).

У пуповині 30 (42,9\%) плацент 1-ї групи переважали артерії з щілиновидним прорізом і гіпертрофією внутрішнього подовжнього шару гладких мязів. Для вен пупковини, навпаки, була характерною ектазія прозору, іноді з тромбами. У пуповині 10 плацент відмічалася запальна інфільтрація стінки пуповини (рис. 2).

Хоріальна платівка в більшості плацент 1-ї групи 60 (85,7\%) досліджень порівняно з контролем була набрякла, судини - повнокровні.

Гістологічна зрілість ворсинкового дерева виявилась неоднорідною: у 30 (42,9\%) гістологічна зрілість ворсин 
не відрізнялась від норми, у 17 (24,3\%) виявлявся варіант проміжних диференційованих ворсин, у 23 (32,9\%) варіант дисоційованого розвитку ворсин.

У субхоріальній та середній зонах плацентарної тканини в 1-й групі у 18 (25,7\%) плацентах домінували ворсини листовидної форми з поодинокими термінальними гілками. Епітелій у них був представлений переважно синцитіотрофобластом. Капіляри цих ворсин вузькі, розташовані переважно в центрі. Особливо характерними, у цих випадках, є ділянки ворсин, розташовані біля материнської поверхні плаценти. Вони складаються 3 щільно розташованих проміжних гілок із поодинокими термінальними ворсинами. Також у цих спостереженнях виявляються ділянки плаценти з потоншеним епітелієм у зонах склеєних ворсин, так званих «афункціональних зонах». Міжворсинковий простір нерівномірно розширений. У частині плацент у міжворсинчастоиу просторі відмічалися явища інтервілузіту (рис. 3).

Виявлені особливості структури ворсинкового дерева відносяться до варіанту незрілості проміжних диференційованих ворсин, що може сприяти скороченню дифузної поверхні ворсинкового дерева, площини гормонсекретуючого сінцитіотрофобласту і об'єму міжворсинкового простору, тобто виникненню хронічної дисфункції плаценти.

Слід зазначити, що у всіх плацентах 1-ї групи у $4,0-5,0 \%$ стовбурових ворсин II і III порядку відмічалася облітерація артерій та артеріол. Дистально розташовані ворсини були замуровані фібриноїдом. У деяких ділянках ворсин епітелій був повністю чи частково відсутній, серед фібриноїдних мас знаходилися стромальні острівці та ізольовані клітини цитотрофобласту.

При мікроскопічному дослідженні плацент 1-ї групи у $25(35,7 \%)$ виявлені вогнищеві зміни децідуальної обо- лонки у вигляді набряку. Судини децидуальної оболонки розширені, повнокровні, місцями з периваскулярними крововиливами в прилеглі тканини та вогнищами запальних змін (децидуїт).

У плацентах із виявленими змінами відмічався середній, вогнищевий рівень компенсаційних реакцій (ангіоматоз судин, розростання термінальних ворсин, інколи проліферація синцитію).

Аналіз плацент 2-ї групи від жінок, яким напередодні пологів проводилось відновлення мікробіоценозу пологових шляхів та кишечнику запропонованою композицією живих штамів лактобактерій, показав зниження обсягів запальної інфільтрації децидуальної та плідної оболонок. У 30 (60,0\%) плацентах не було запальної інфільтрації в міжворсинковому просторі (інтервілузіт). У ворсинах зустрічалися поодинокі вогнища лімфоїдної інфільтрації, обсяг якої не дає підстави діагностувати вілузіт. У 17 (34,0\%) плацентах цієї групи відмічалися вогнища запальної інфільтрації в децидуальній оболонці та в міжворсинковому просторі біля децидуальної оболонки, у 8 (16,0\%) плацентах лише в децидуальній оболонці.

\section{Висновки}

У плацентах від жінок із ХП у 60\% відмічено вогнищеві прояви плацентарної дисфункції на фоні запальних змін у міжворсинчастому просторі, децидуальній та плідній оболонках. При застосуванні пробіотичної композиції прояви плацентарної дисфункції виявлено в $40 \%$ на фоні зменшення запальних змін у децидуальній оболонці і мідворсинчастому просторі. У $16 \%$ плацент встановлено тільки вогнищеві зміни запального характеру в децидуальній оболонці (децидуїт).

\section{ЛIТЕРАТУРА}

1. Акушерство: нац. руководство / Э.К. Айламазян, В.И. Кулаков, В.Е. Радзинский [и др.]. - М.: ГЭОТАР-Медиа, 2007. - 1200 с.

2. Архипова Н.А. Аналіз перебігу вагітності, перинатальних утрат і стану надання спеціалізованої медичної допомоги вагітним із захворюваннями нирок / Н.А. Архипова, І.М. Грицай, О.О. Данилов // Здоровье женщины. - 2009. - № 3 (39). - С. 55-58.

3. Діагностика та лікування плацентарної недостатності / Б.М. Венцківський, В.М. Запорожан, А.В. Заболотна [та ін.]. Київ, 2004. - 23 C.

4. Иремашвили В.В. Инфекции мочевыводящих путей: современный взгляд на проблему / В.В. Иремашвили // Русский мед. журнал. - 2010. - № 5, Т. 29. - С. 2231-2236.

5. Меленчук Л.М. Пренатальна оцінка стану плода у вагітних жінок з іфекційними захворюваннями сечовидільної системи: автореф. дис. ... к.мед.н. / Л.М. Меленчук. - Львів, 2011. - 18 с.

6. Особенности биоценоза влагалища у женщин с нормальным и промежуточным типом мазка по результатам полимеразной цепной реакции в режиме реального времени / Л.В. Тумбинская,
Е.С. Ворошилина, А.Е. Донников [и др.] // Акушерство и гинекология. -2011 . - № 1. - С. 66-70.

7. Серов В.Н. Гестационный пиелонефрит: диагностика, профилактика, лечение / В.Н. Серов, В.Л. Тютюнник // РМЖ. Мать и дитя. Акушерство и гинекология. - 2008. - № 1 (16). - С. 4-7.

8. Серов В.Н. Плацентарная недостаточность / В.Н. Серов // Трудный пациент. - 2005. - Т. 3, № 2. - С. 18-19.

9. Сидорова И.С. Прогнозирование исходов беременности и родов при остром гестационном пиелонефрите / И.С. Сидорова // Акушерство и гинекология. - 2010. - № 4. - С. 37-40.

10. Фофанова И.Ю. Особенности инфекционных процессов мочевыводящих путей в акушерско-гинекологической практике. Гинекология / И.Ю. Фофанова, А.В. Ледина // Журнал для практикующих врачей. - 2011. - № 2 (13). - С. 27-30.

11. The prevalence of vaginal microorganisms in pregnant women with preterm labor and preterm birth / S.J. Choi, S.D. Park, I.H. Jang, Y. Uh // Annals of Laboratory Medicine. - 2012. Vol. 32 (3). - P. 194-200.

\section{Влияние пробиотиков на состояние плацентарного барьера у беременных с хроническим пиелонефритом} Н.К. Деменина, О.И. Ещенко, А.И. Ищенко, А.В. Милевский

ГУ «Институт педиатрии, акушерства и гинекологии НАМН Украины», г. Киев, Украина Цель - изучить морфологические особенности плаценты у беременных с хроническим пиелонефритом.

Пациенты и методы. Для изучения морфологических особенностей плаценты исследованы следующие группы: 1-я группа — 70 плацент от женщин, больных хроническим пиелонефритом, получавших курс лечения по поводу основного заболевания, согласно действующим рекомендациям; 2-я группа - 50 плацент от женщин с хроническим пиелонефритом, которым дополнительно проводили восстановление микробиоценоза родовых путей и кишечника пробиотической композицией живых штаммов L.plantarum BKПМ B-5002 и Str. salivarius subsp. thermophilus BKПМ B-3813 в cooт- 
ношении 8:2 в дозе 108-109 КОЕ/мл накануне родов; 3-я группа (контроль) - 25 плацент от здоровых женщин с фризиологическим течением беременности. Для изучения морфологических особенностей плаценты в обследованных женщин использованы следующие методы: органометрический, макроскопический, гистологический.

Результаты. В группе женщин с хроническим пиелонесритом (1-я группа), по совокупности органометрических, макроскопических и гистологических особенностей, в 60\% плацент отмечена дисфункция очагового характера с элементами незрелости по типу промежуточных диффференцированных ворсин и диссоциированного развития ворсин на фоне компенсаторных реакций, как на клеточном, так и на тканевом уровне, средней степени выраженности. У $36 \%$ плацент обнаружены очаговые изменения децидуальной оболочки в виде отека, полнокровия сосудов и децидуита, явления париетального мембранита в плодовых оболочках и интервилузита в межворсинчатом пространстве.

В группе женщин с хроническим пиелонесритом (2-я группа), которые дополнительно получали пробиотическую композицию, в 60\% плацент воспалительные изменения очагового характера отсутствовали, только в 34\% плацент отмечены очаги воспалительной инфильтрации в децидуальной оболочке и в межворсинчатом пространстве под децидуальной оболочкой, а в 16\% плацент - только в децидуальной оболочке.

Выводы. В $60 \%$ плацент от женщин с хроническим пиелонефритом отмечены очаговые проявления плацентарной диссрункции на фоне воспалительных изменений в межворсинчатом пространстве, децидуальной и плодовой оболочках. При применении пробиотической композиции проявления плацентарной дисфункции выявлены в 40\% на фоне снижения воспалительных изменений в децидуальной оболочке и межворсинчатом пространстве. В 16\% плацент определены только очаговые изменения воспалительного характера в децидуальной оболочке (децидуит).

Ключевые слова: хронический пиелонефрит, беременность, плацента.

PERINATOLOGIYA I PEDIATRIYA.2015.2(62):12-15;doi10.15574/PP.2015.62.12

The effect of probiotics on the state of placental barrier in pregnant women with chronic pyelonephritis

N.K. Demenina, Y.I. Yeschenko, H.I. Ischenko, O.V. Milievskyi

SI «Institute of Pediatrics, Gynecology and Obstetrics NAMS of Ukraine», Kyiv, Ukraine

Purpose - to study the morphological and morphometric features of placenta in pregnant women with chronic pyelonephritis.

Patients and methods. The study of morphological characteristics of placenta was conducted in the following groups. Group I - 70 placentas from women with chronic pyelonephritis who received treatment according to current recommendations. Ggroup II -50 placentas from women with chronic pyelonephritis who have additionally undergone restoration of birth canal and intestinal microbiocenosis with probiotic composition of live strains $L$.plantarum BKחM B-5002 and Str. salivarius subsp. thermophilus ВКПM B-3813 at a ratio of 8:2 and dose of $108-10^{9} \mathrm{CFU} / \mathrm{ml}$ before childbirth. Group III (control) — placentas from healthy women with normal pregnancy. To study the morphological features of placentas used organometric, macroscopic, histological methods.

Results. In the group of women with chronic pyelonephritis (group I), multiple histologic and morphometric features of placentas showed 2 degree chronic placental insufficiency with the elements of immaturity according to the type of differentiated intermediate villi and dissociated villi in $60 \%$ of cases. In this group the focal changes in decidua as swelling and thickening were found in $36 \%$ of placentas. Sometimes deciduas were infiltrated by lymphocytes, plasma cells, segmented neutrophils, so inflammation of decidua was observed.

In the group of women with chronic pyelonephritis who additionally received probiotic composition (group II), $40 \%$ of placentas had histological and morphological sings of 1-2 degree chronic placental insufficiency. The phenomenon of inflammatory infiltration in decidua and intervillous space was found in $34 \%$ of placentas of this group.

Conclusions. We found structural features that indicate the 2 degree chronic placental insufficiency and a high level of inflammatory infiltration of decidua in placentas from women with chronic pyelonephritis.

Key words: chronic pyelonephritis, pregnancy, placenta.

Сведения об авторах:

Деменина Надежда Казимировна - к.мед.н., н.сотр. отделения профилактики и лечения гнойно-воспалительных заболеваний в акушерстве ГУ «ИПАГ НАМН Украины». Адрес: г. Киев, ул. П. Майбороды, 8; тел. (044) 483-22-31.

Ещенко Ольга Ивановна - к.мед.н., ст.н.сотр. лаборатории патоморфологии ГУ «ИПАГ НАМН Украины».

Адрес: г. Киев, ул. П. Майбороды, 8.

Ищенко Анна Ивановна - к.мед.н., н.сотр. отделения профилактики и лечения гнойно-воспалительных заболеваний в акушерстве ГУ «ИПАГ НАМН Украины». Адрес: г. Киев, ул. П. Майбороды, 8; тел. (044) 483-22-31.

Милевский Александр Валерьевич - к.мед.н., ст.н.сотр. отделения профилактики и лечения гнойно-воспалительных заболеваний в акушерстве ГУ «ИПАГ НАМН Украины». Адрес: г. Киев, ул. П. Майбороды, 8; тел. (044) 483-22-31.

Статья поступила в редакцию 27.04.2015 г. 


\title{
И.С. Лукьянова 1, Я.П. Труба2, Г.Ф. Медведенко1, Е.Д. Жадан1, Л.А. Иванова1 \\ Аномалии дуги аорты: проблемы пренатальной и постнатальной тактики
}

1 ГУ «Институт педиатрии, акушерства и гинекологии НАМН Украины», г. Киев, Украина

2 ГУ «Национальный институт сердечно-сосудистой хирургии имени Н.М. Амосова НАМН Украины», г. Киев, Украина

\author{
PERINATOLOGIYA I PEDIATRIYA.2015.2(62):16-21;doi10.15574/PP.2015.62.16
}

Цель - на основании данных литературы и анализа собственных результатов выработать рекомендации по улучшению выявления аномалий аорты для обеспечения своевременной кардиохирургической помощи.

Пациенты и методы. В ГУ «ИПАГ НАМНУ» и ГУ «НИССХ им. Н.Н.Амосова НАМНУ» за период 2011-2014 гг. наблюдались пренатально 222 беременные, а постнатально - 169 новорожденных с гемодинамически значимыми врожденными пороками сердца, из них 39 детей с патологией дуги аорты. Ведущая роль в диагностике врожденного порока сердца и оказания своевременной кардиохирургической помощи новорожденному принадлежала фетальной эхокардиографии. С целью уточнения диагноза и определения дальнейшей тактики все дети были консультированы в ГУ «НИССХ им. Н.М. Амосова». При выявлении случаев изолированной критической коарктации аорты или гипоплазии дуги аорты, новорожденные в первые сутки и даже часы жизни были госпитализированы в отделение врожденных пороков сердца.

Результаты. У 18 (46,2\%) детей гипоплазия дуги аорты входила в состав синдрома гипоплазии левых отделов сердца.

Выводы. При диагностике или подозрении на патологию дуги аорты у плода (изолированную или в сочетании с другими аномалиями сердца) обязательное уведомление неонатологов способствует своевременной постановке диагноза и оказанию, в случае необходимости, кардиохирургической помощи еще до развития осложнений.

Ключевые слова: плод, новорожденный, аномалия дуги аорты, пренатальная ЭхоКГ, кардиохирургия.

\section{Введение}

В рожденные аномалии развития сердца являются Одной из самых распространенных причин, которые могут не только ухудшить качество жизни, но и значительно сократить ее. Как правило, проблемы, связанные с врожденными пороками сердца (ВПС), решаются хирургическим путем. Опыт зарубежных коллег показывает, что частота ВПС колеблется в пределах 10-13 случаев на 1000 живорожденных, из этих случаев около половины составляют сложные аномалии развития сердца. В Украине на протяжении последних 10 лет, по данным статистики, в разные годы средняя частота ВПС колеблется от 8 до 11-12 случаев на 1000 живорожденных. К сожалению, при сложных формах ВПС без своевременного хирургического лечения в раннем младенчестве погибает до 50\% детей [1].

Выявляемость и точность диагностики в пренатальный период существенно зависит от нозологической формы порока. Так, например, грубые аномалии развития сердца (атрезия митрального и трикуспидального клапанов, общий желудочек, атрезия одного из магистральных сосудов, заболевания миокарда и т.д.) выявляются в достаточно раннем периоде и позволяют решить вопрос о целесообразности пролонгирования беременности, точность их диагностики по данным различных источников, составляет 40-90\% Однако при пороках, которые проявляют себя в более поздние гестационные сроки (коарктация аорты, некритическая гипоплазия дуги, некритические стенозы аорты и легочной артерии и т.д.), выбор правильной постнатальной тактики нередко затруднен [1].

Одним из таких пороков, которые представляют трудности для пренатальной и постнатальной диагностики (особенно в первые сутки жизни), является патология дуги аорты (от изолированной коарктации до перерыва дуги) Латинский термин «coarctatius» означает «суженный, стиснутый». Впервые его описал J.F. Meckel в 1750 г. Коарктация аорты - это патологическое сужение ее просвета, которое может возникнуть в любом месте по всей ее длине. Частота порока составляет 6,3\% (по данным клинических наблюде- ний из выборки в 2000 случаев) и 8,4\% (по результатам патологоанатомического материала) [8]. При сочетании коарктации аорты с экстракардиальными пороками и хромосомными аномалиями точность ее пренатальной диагностики была существенно выше за счет выраженности гемодинамических нарушений и расширенного эхокардиографического (ЭхоКГ) исследования плода и составила 52\%.

Коарктация аорты занимает четвертое место среди ВПС по встречаемости у детей первого года жизни. Как правило, она развивается дистальнее места ответвления левой подключичной артерии вблизи артериального протока (ductus arteriosus). В зависимости от локализации сужения аорты относительно артериального протока (АП) различают два классических типа коарктации: предуктальную и постдуктальную [1].

После закрытия АП клиническая картина может нарастать достаточно быстро. Следует заметить, что в течение первого года погибает 56\% пациентов при несвоевременно установленном или вовсе не установленном диагнозе [4]. В основном смертельный исход вызван сочетанием коарктации с другими аномалиями сердца. Изолированная форма в первые недели и дни жизни при неоказании кардиохирургической помощи также характеризуется высоким процентом летальности (34\%). К серьезным осложнениям приводит и патология всей дуги - гипоплазия одного или нескольких сегментов, полный перерыв дуги. По данным патоморфологических исследований, причиной смерти новорожденных является сердечнолегочная недостаточность, а при развитии артериальной гипертензии - внутричерепные кровоизлияния [8].

Цель работы - на основании данных литературы и анализа собственных результатов выработать рекомендации по улучшению выявления аномалий аорты для обеспечения своевременной кардиохирургической помощи.

\section{Материалы и методы исследования}

В основе диагностики любого врожденного порока развития лежит система скринингового обследования беременных женщин. 
Отбор беременных на пренатальную ЭхоКГ и ультразвуковое исследование (УЗИ) проводился на основании следующих факторов: врожденные аномалии у матери (в т.ч. сердца и сосудов), метаболические нарушения, такие как сахарный диабет, инфекции (TORCH-комплекс и др.), экстрагенитальная патология (приобретенные пороки сердца, артериальная гипертензия, коллагенозы и др.), прием лекарств, обладающих тератогенным действием (антиконвульсанты, прогестерон, эстрогены и др.), тяжелые нарушения функции почек, возраст матери, выраженная угроза прерывания в первом триместре, вредные факторы на предприятии на ранних стадиях гестации, наличие экстракардиальных аномалий у плода. Кроме того, изучение сердечно-сосудистой системы плода проводилось при подозрении на сердечную патологию, обнаруженную во время рутинного обследования в женской консультации.

Наиболее оптимальными сроками для ЭхоКГ плода 20-24 и 30-32 недели беременности. После 36-37 недель беременности получить полноценное изображение сердца плода становится значительно сложнее, особенно при фиксированном переднем виде плода, вследствие выраженного отражения ультразвуковых волн от ребер и позвоночника.

Всем беременным выполнялось полное ЭхоКГ плода с установлением топического диагноза, функциональной оценки желудочков сердца, а также оценки гемодинамических нарушений в фетоплацентарной системе, выявление сопутствующей патологии.

У плодов с заболеваниями левых отделов сердца с течением гестационного периода часто наблюдалось прогрессирование тяжести порока. Поэтому в случае диагностики ВПС внутриутробно, ЭхоКГ плода проводилось каждые 4-6 недель для мониторирования желудочковой дисфункции, клапанной регургитации и контроля роста анатомических структур, которые могли поражаться нарушенным антеградным кровотоком. Общее состояние плода оценивалось по наличию признаков внутриутробной задержки роста плода, плацентарной дисфункции и дистресса плода, сердечной недостаточности с развитием водянки плода.

Для обеспечения оптимальной помощи как матери, так и новорожденному в перинатальном периоде решающее значение имело налаживание обмена информацией между акушерами, специалистами УЗИ, неонатологами, детскими кардиохирургами и определение оптимального места рождения ребенка с диагностированным пренатально критическим пороком сердца.

При обнаружении патологии сердечно-сосудистой системы у плода результаты обследования сообщались в отделение неонатологии и отделение реанимации новорожденных. Такая последовательность позволяла наиболее тщательно обследовать новорожденных сразу после рождения и принять верное решение о дальнейшей тактике ведения.

Пренатальное и постнатальное УЗИ проводилось на аппаратах «Acuson X300» (Siemens, Германия), «Medison SA-9900» (Корея), «ESAOTE MyLab» (Италия).

\section{Результаты исследования и их обсуждение}

Пренатально в отделении лучевой диагностики и пренатальной кардиологии ГУ «ИПАГ НАМНУ» совместно с ГУ «НИССХ им. Н.М. Амосова» в 2011-2014 наблюдались 222 беременные с ВПС у плода в сроках 16-41 недель гестации. Диагноз патологии аорты у плода был установлен у 57 беременных. Из них в 40 (70\%) случаях аномалия развития аорты входила в синдром гипоплазии

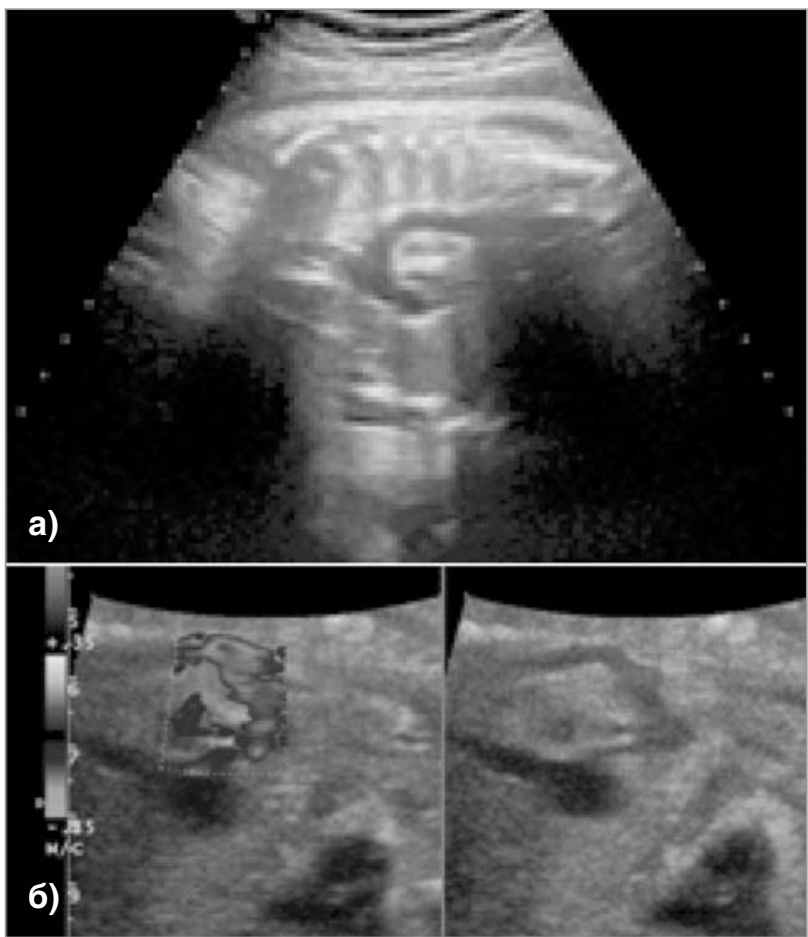

Pис. 1. Пренатальное изображение аорты плода: а) - плод 39 недель, аорта без патологии; б) - плод 37 недель, выраженное сужение аорты с дилатацией дистального отдела

левых отделов сердца, в 17 (30\%) - отмечалась изолированная патология аорты. Нередко (4 случая $-7 \%$ ) врожденный порок сердца сочетался с другой врожденной патологией - аневризмой вены Галлена, аномалией развития правого легкого, атрезией толстого кишечника, омфалоцеле. Из особенностей течения беременности следует отметить развитие дистресса плода в 3 случаях, плацентарной дисфункции - в 3 случаях, синдрома задержки развития плода - в 1 случае, аденовирусной инфекции в раннем сроке беременности - в 1 случае. Многоплодная беременность выявилась у 3 женщин, нарушения ритма у плода в виде частой экстрасистолии - в 3 случаях.

Постнатально в ходе комплексного обследования у 169 новорожденных подтверждались гемодинамически значимые ВПС. Из них у 39 новорожденных диагностировались аномалии аорты. Пренатальный диагноз патологии дуги аорты основывался на прямом признаке визуализации места сужения аорты и, возможно, наличии расширения дистального отдела аорты. Однако четко визуализировать участок сужения аорты у плода достаточно трудно и удается только в единичных наблюдениях. Порок можно увидеть лишь тогда, когда имеется уменышение диаметра перешейка аорты более чем на 1/3 по сравнению с нормой для каждого срока беременности (рис. 1).

Согласно рекомендациям многих исследователей, основным в пренатальной диагностике аномалий дуги следует считать оценку самих главных артерий с использованием всех рекомендуемых срезов (через три сосуда, дуга аорты, длинная ось легочной артерии) в сочетании с оценкой четырехкамерного среза сердца (дилатация правого желудочка, гипертрофия и уменьшение полости левого желудочка). Одним из маркеров наличия коарктации можно считать уменьшение диаметра аорты в среднем в 2,5 раза, чем диаметр дилатированной легочной артерии. Поэтому для диагностики 

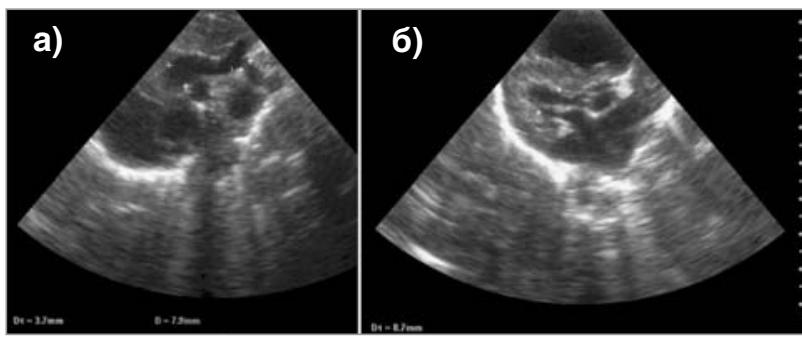

Pис. 2. Доношенный новорожденный, 1 час жизни, синдром гипоплазии левых отделов сердца: а) - гипоплазия дуги аорты; б) - гипоплазия митрального клапана, левого желудочка и атрезия аортального клапана

коарктации аорты использовалась визуализация самой аорты, что наиболее показательно при скрининговой оценке среза через три сосуда [6]. Так же маркером коарктации было расширение АП (более 3-4 мм), однако после 37 недель его визуализация затруднялась из-за положения плода. При проведении обследования также обращалось внимание на наличие лево-правого шунта через овальное окно. Заподозрить патологическое шунтирование возможно было по нарушенному кинезу клапана овального окна. Следует отметить, что сужение может охватывать большой участок аорты вплоть до гипоплазии сегмента дуги. Кроме того, при исследовании аорты по длинной оси наиболее надежным признаком следует считать гипоплазию поперечной части дуги аорты. Как один из косвенных признаков коарктации аорты можно использовать извилистость дуги аорты при изучении ее по длинной оси (рис. 1.б).

Нарушения гемодинамики и сердечная недостаточность характеризовались антенатально наличием выпота в перикарде, уменьшением сердечного выброса с уменьшением размеров левого желудочка, что являлось достоверным признаком неблагоприятного постнатального прогноза.

Среди 39 новорожденных с аномалиями аорты (от незначительного сужения до полного перерыва) у 34 (87\%) диагноз патологии аорты был поставлен антенатально, а в 4 случаях, в связи с проведением экспертной ЭхоКГ плода в поздние сроки беременности (38-40 недель), выявлено подозрение на патологию дуги и рекомендовано проведение ЭхоКГ новорожденному в первые часы после рождения. В одном случае диагноз коарктации аорты установлен при проведении профилактического обследования новорожденного перед выпиской из роддома (4-е сутки жизни).

При родоразрешении предпочтение отдавалось срочным спонтанным родам, поскольку известно, что доношенные дети имеют энергетический резерв, накопленный в течение третьего триместра, которого нет у недоношенных новорожденных, а также имеют меньшую вероятность возникновения электролитных нарушений, респираторного дистресс-синдрома, некротического энтероколита и внутрижелудочковых кровоизлияний, что согласуется с рекомендациями Американской ассоциации кардиохирургов.

Стимуляция родов и кесарево сечение применялись в случаях, когда имело место многоводие неиммунного происхождения, признаки дистресса плода. Путем кесарева сечения родились $3(7,7 \%)$ малышей. В состоянии асфиксии тяжелой степени родился 1 (2,5\%) ребенок. Без признаков асфиксии родилось 7 (17,9\%) детей, остальные 28 (71,8\%) - в состоянии асфиксии умеренной степени. Доношенными родились 36 (92,3\%) детей и $3(7,7 \%)$ - недоношенными. Масса большинства
$(82,1 \%)$ детей при рождении составляла $>3000$ г, что свидетельствовало о достаточно удовлетворительных условиях внутриутробного развития даже при таких тяжелых формах врожденных аномалий сердечно-сосудистой системы, как синдром гипоплазии левых отделов сердца, которые имели высокий уровень ранней неонатальной смертности.

Девочек было 10 (25,6\%), мальчиков - 29 (74,4\%), что согласуется с данными литературы: у мальчиков эта патология сердечно-сосудистой системы встречается в 2-3 раза чаще [4]. Как правило, дети с данной патологией рождались с относительно неплохими показателями насыщения кислорода - в пределах 94-96\%, так как в первые сутки жизни ребенка системный кровоток обеспечивался функционирующим АП и только на 2-3-е сутки при закрытии АП развивались нарушения гемодинамики.

Помощь новорожденному с диагнозом ВПС в родильном зале определялась известными принципами: согревание, стимуляция, обеспечение проходимости дыхательных путей, эффективности дыхания и кровообращения. Медикаменты и средства для пополнения объема внутрисосудистой жидкости включали: кристаллоидноколлоидные растворы, бикарбонат, допамин, адреналин и простогландины $\mathrm{E} \& \& 1$.

При первичной оценке новорожденного с пренатальным диагнозом ВВС проводилось изучение анамнеза, физикальная оценка с измерением артериального давления на конечностях, ЭхоКГ, электрокардиография (ЭКГ). После рождения ребенка обращалось внимание на цвет кожи (бледный, периферический цианоз, центральный цианоз), респираторные показатели (тахипное, брадипное, респираторный дистресс), оценивалась периферическая перфузия (бледность, «мраморность» кожных покровов, нарушение терморегуляции). Исследовалась также пульсация бедренных артерий и другие
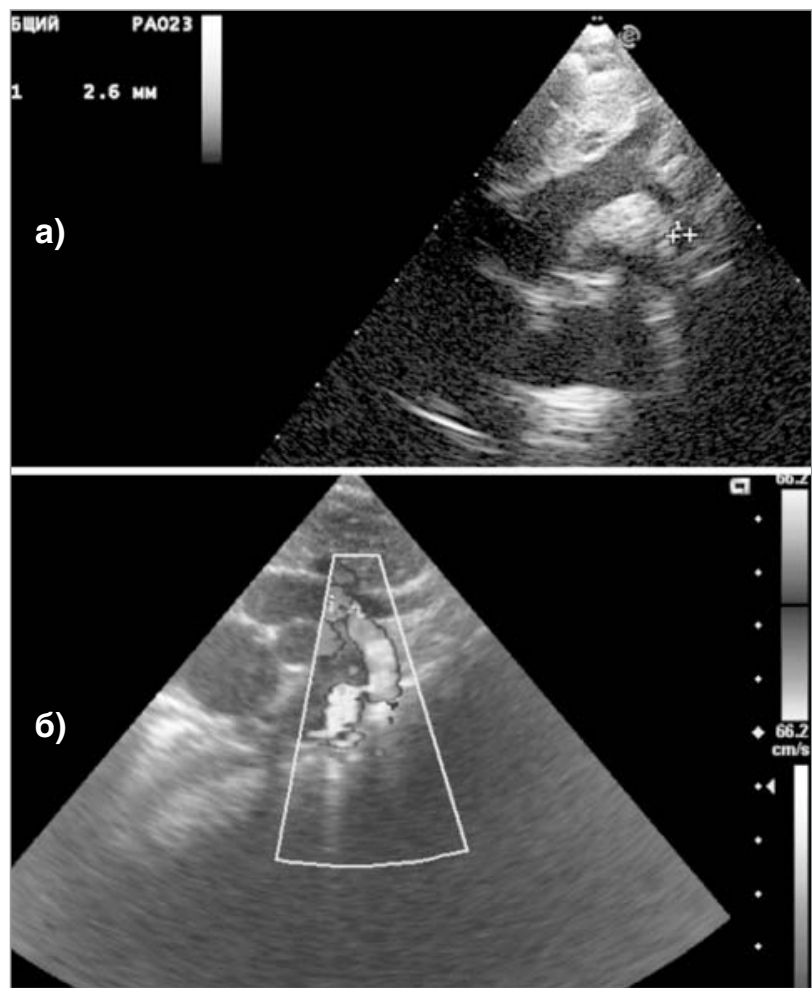

Pис. 3. (а, б). Новорожденный, 1-е сутки жизни. Гипоплазия сегментов А и В, коарктация аорты 

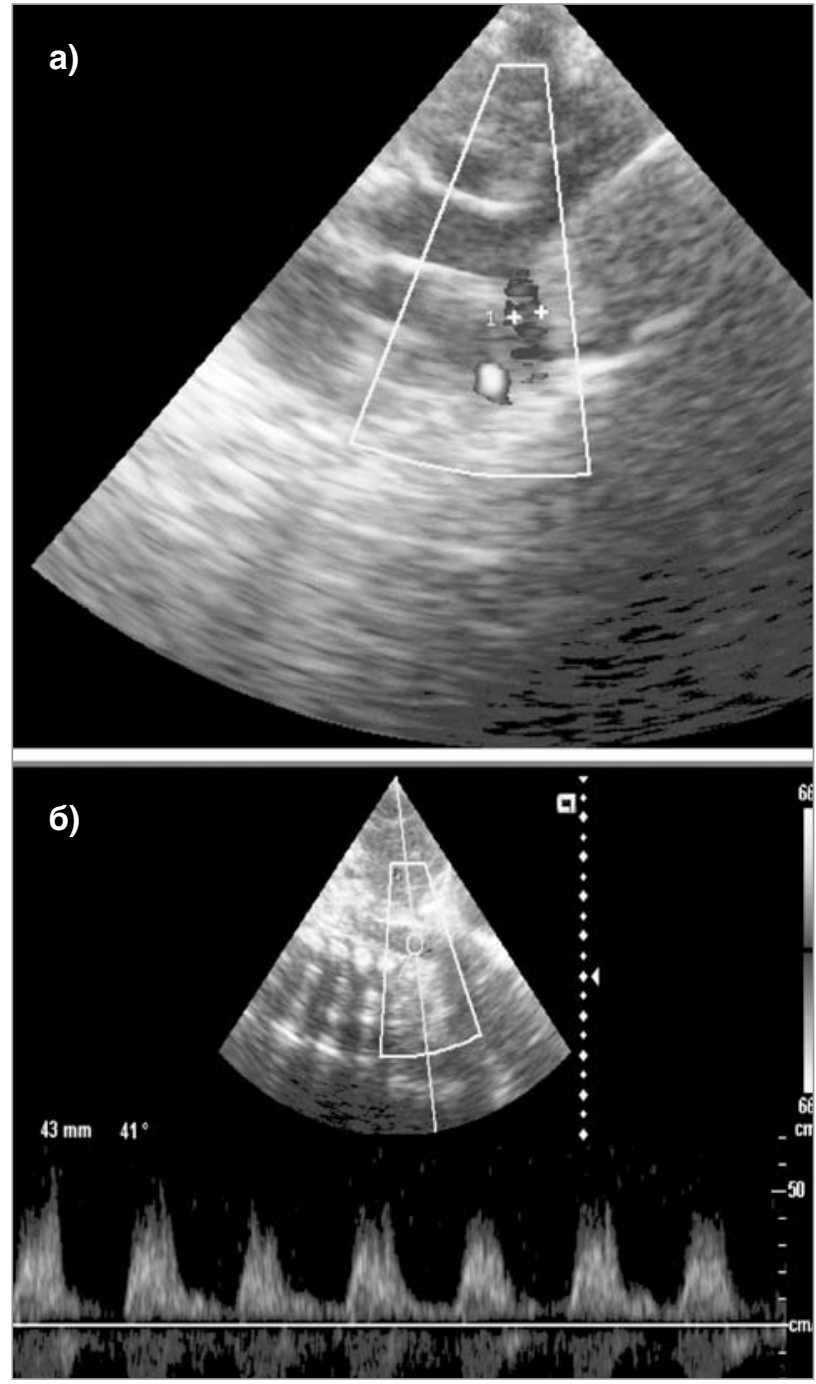

Pис. 4. (a) Гипоплазия сегмента В (1,2 мм) при неизмененном кровотоке в брюшной аорте (б) в первые часы жизни

признаки нарушений артериальной перфузии (олигоанурия, парез кишечника, метаболический ацидоз).

Затруднения диагностики возникали при изолированной коарктации. К сожалению, не исключаются случаи, когда при пренатальном обследовании сужение аорты не выявляется, особенно если оно формируется после рождения при закрытии АП. В данной ситуации заподозрить коарктацию помогало клиническое наблюдение: снижение диуреза, снижение или отсутствие пульсации на бедренных артериях, разница артериального давления (АД) на верхних и нижних конечностях более 20 мм рт. ст.

Следует отметить, что постдуктальная коарктация развивается уже после рождения и часто представляет собой изолированный дефект. Существует теория, что данная аномалия, вероятнее всего, является результатом разрастания мышечной ткани АП в аорту плода [3] Когда же проток после рождения сужается, эктопическая ткань внутри аорты также сжимается, перекрывая просвет сосуда по всей его окружности. В отличие от предуктальной коарктации в данном случае гипоплазия аорты не развивается. Закрытие АП у некоторых детей приводит к наличию сужения аорты и развитию коарктации через 1-3 месяца после рождения. Исходя из этого, в сомни-
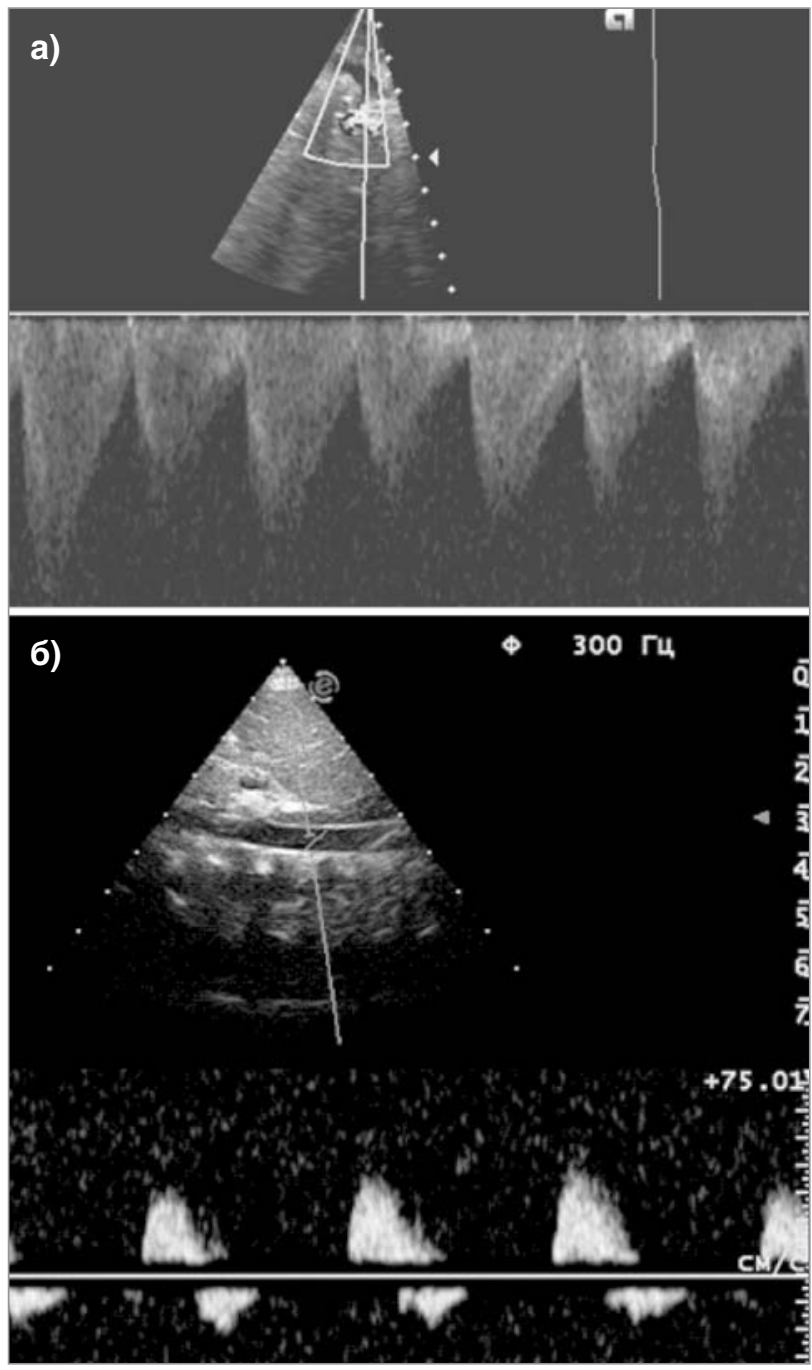

Pис. 5. Патологические изменения спектра кровотока у доношенного новорожденного на 3-и сутки жизни в нисходящей (а) и брюшной аорте (б)

тельных случаях следует проводить ЭхоКГ после рождения и в динамике после закрытия АП.

С целью уточнения диагноза и определения тактики ведения все дети были консультированы в ГУ «НИССХ им. Н.М. Амосова». При выявлении случаев изолированной критической коарктации аорты или гипоплазии дуги аорты дети в первые сутки, и даже часы жизни, были госпитализированы в отделение врожденных пороков сердца. У 18 (46,2\%) детей гипоплазия дуги аорты входила в состав синдрома гипоплазии левых отделов сердца (рис. 2).

Из 20 (51,3\%) детей, которые имели только признаки сужения одного или нескольких сегментов аорты, у 5 младенцев диагностировалась коарктация аорты (рис. 3), у 2 - полный перерыв дуги.

Допплер-ЭхоКГ позволяет выявить характерные для коарктации признаки: турбулентный систолический поток ниже места сужения (рис. 3б), разницу систолического АД между частью аорты перед сужением и ее частью ниже сужения. Следует отметить, что трудности в диагностике этих случаев составляет отсутствие таких критериев коарктации, как повышение градиента давления в месте сужения, снижение скорости кровотока и изменение спектра в брюшной аорте при проведении допплеро- 


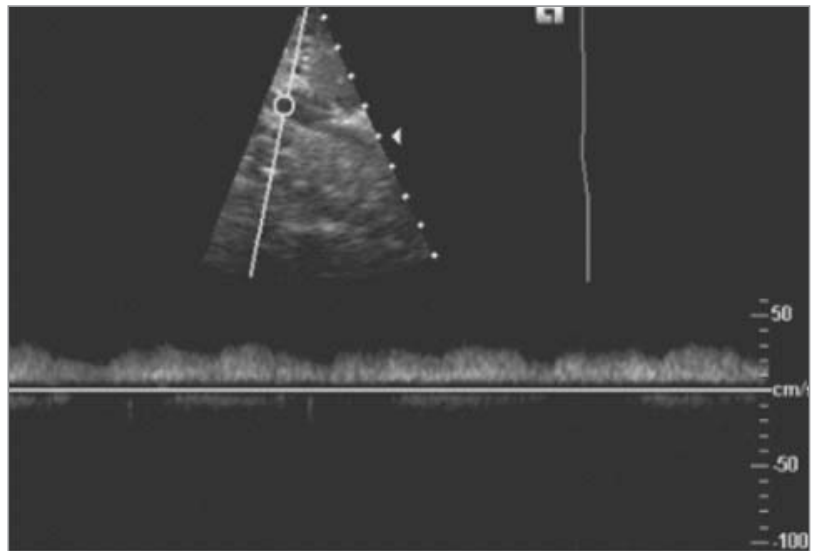

Pис. 6. Спектр кровотока в брюшной аорте, близкий к ламинарному со снижением скорости менее $20 \mathrm{~cm} / \mathrm{c}$ (доношенный новорожденный, 2-е сутки жизни)

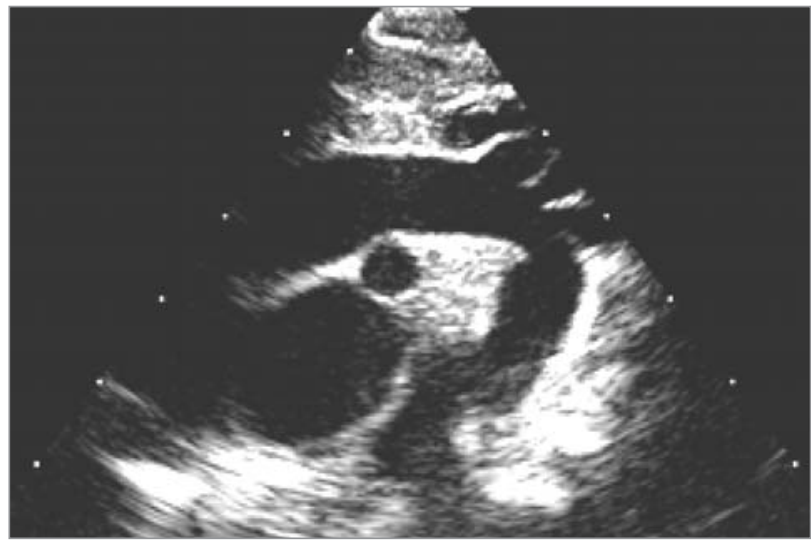

Pис. 7. Десормация аорты в виде удлинения и извитости без изменения ее просвета и препятствия кровотоку (доношенный новорожденный, 5-е сутки)

графии в первые сутки жизни. Выявление места сужения аорты в В-режиме затрудняется из-за функционирования широкого АП. Как отмечено в литературе, юкстадуктальное впадение АП (расположение АП на уровне сужения аорты) вовлекает в процессе своего закрытия и аортальную стенку, что приводит к ее критическому сужению [8]

На рис. 4, 5 представлена динамика изменений спектра кровотока в брюшной аорте на 1-3-е сутки жизни.

Изменение кровотока в нисходящей и брюшной аорте на рис. $5(\mathrm{a}$, б) продемонстрировали выраженные нарушения - спектр в виде «пилы» (рис. 5а) и ретроградного компонента (рис. 5б), спектр близкий к ламинарному со снижением скорости кровотока менее $20 \mathrm{~cm} / \mathrm{c}$ (рис. 6) требующие немедленного назначения препаратов простагландина $\mathrm{E} \& \& 1$ с целью сохранения открытого АП, до проведения радикальной коррекции коарктации.

В одном случае при обследовании ребенка после рождения был поставлен диагноз «кинкинг аорты» деформация аорты за счет удлинения и извитости без изменения ее просвета и препятствия кровотоку (рис. 7).

Исходя из вышеизложенного, наиболее достоверно выявить антенатально патологию дуги аорты можно в случаях значительных анатомических изменений в виде стеноза или атрезии аортального клапана, патологии митрального клапана, гипоплазии левого желудочка, увеличения диаметра легочной артерии, когда при проведении скриннингового обследования беременной в определенные протоколом (приказ М3 Украины № 764) сроки гестации [5] очевидна аномалия развития сердца. В случаях, когда при проведении ЭхоКГ в первые часы жизни не всегда можно дать ответ, есть ли у новорожденного коарктация аорты, необходима отлаженная тактика клинико-инструментального мониторинга состояния гемодинамики: контроль АД на верхних и нижних конечностях, показателей насыщения кислородом, диурез, определение феморального пульса и проведение ЭхоКГ в динамике первых суток жизни ребенка.

\section{Выводы}

При проведении скринингового обследования беременных следует оценивать не только 4-камерную позицию сердца плода, но и обязательно определять состояние дуги аорты, о чем отмечать в протоколе исследования, особенно в случае нечеткой ее визуализации.

В случае невозможности четкого лоцирования дуги аорты и изменений ее анатомии (диаметра в разных сегментах, радиуса) в сроки, определенные протоколом ведения беременности при подозрении на ВПС, необходимо рекомендовать обследование ребенка после рождения (до выписки из родовспомогательного учреждения).

При диагностике или подозрении на патологию дуги аорты у плода (изолированную или в сочетании с другими аномалиями сердца) следует обязательно уведомить об этом неонатологов, что способствует своевременной диагностике и оказанию при необходимости кардиохирургической помощи до развития осложнений.

При отсутствии убедительных данных о наличии у новорожденного коартктации аорты при подозрении на нее пренатально необходимо проводить клинико-инструментальный мониторинг в раннем неонатальном периоде (пульсоксиметрию и измерение АД на верхних и нижних конечностях с оценкой характера пульса, контроль диуреза с УЗИ - оценкой почечного кровотока, проведение ЭхоКГ на 1-3-е сутки в динамике, готовность к инфузии простагландина для сохранения функционирования АП при развитии критического сужения аорты).

\section{ЛИТЕРАТУРА}

1. Верновський Г. Дослідження в перинатології. Серцево-судинні захворювання у новонароджених / Г. Верновський, С. Давід Рубенстайн; пер. $з$ англ. - Київ : Фонд допомоги дітям Чорнобиля, 2004. $-312 \mathrm{c}$.

2. Врожденный порок сердца [Электронный ресурс] - Режим доступа: http://dic.academic.ru/dic.nsf/ruwiki/853722. - Название с экрана.

3. Затикян Е.П. Коарктация аорты у плода. Точность и ошибки диагностики [Электронный ресурс] / Е.П. Затикян // Медицинский журнал
«SonoAce-Ultrasound». - 2013. - Vol. 25. - Режим доступа: http://www.medison.ru/si/art368.htm. - Название с экрана.

4. Коарктация аорты у ребенка. Врожденная коарктация аорты [Электронный ресурс] // Медицинский журнал «SonoAce-Ultrasound». 2013. - Vol. 25. - Режим доступа: http://medicalplanet.su/cardiology/53.html. - Название с экрана.

5. Про затвердження Клінічного протоколу з акушерської допомоги «Ведення вагітності і пологів у вагітних із пренатально встано- 
вленими вродженими вадами серця плода»: наказ М03 України від 01.10.2012 № 764 [Електронний ресурс]. - Режим доступу: http:www.moz.gov.ua. - Назва з екрана.

6. Ультразвуковая диагностика врожденных пороков сердца у плода / У.Д. Беспалова, О.Г. Суратова, А.И. Тюменева, Р.М. Гасанова; под ред. Л.А. Бокерия. M., 2009.
7. Allan L.D. Fetal Echocardiographiy. A practical guide / L.D. Allan, A.C Cook, I.C. Huggon // Cambridge University Press. - 2009. - P. 258.

8. Antenatal diagnosis of posductal coarctation of the aorta report / F. Oztunc, A.G. Eroglu, F. Aksoy [et al.] // Turk journal Pediatr. — 2001 Vol. 43, № 1. - P. 67-69.

9. Prenatal diagnosis of coarctation of the aorta improves surviva and reduces morbility / O. Franklin, M. Burch, N. Manning [et al.] // Heart. - 2002. - Vol. 87, № 11. - P. 67-69.

\section{Аномалії дуги аорти: проблеми пренатальної та постнатальної тактики}

І.С. Лук'янова1, Я.П. Труба2, Г.Ф. Медведенко1, О.Д. Жадан1, Л.А. Іванова²

1 ДУ «Інститут педіатрії, акушерства і гінекології НАМН України», м. Київ, Україна

2ДУ «Національний інститут серцево-судинної хірургії імені М.М. Амосова НАМН України», м. Київ, Україна

Мета — на підставі даних літератури і аналізу власних результатів виробити рекомендації з поліпшення виявлення аномалій аорти для забезпечення своєчасної кардіохірургічної допомоги.

Пацієнти та методи. У ДУ «ПАГ НАМНУ» та ДУ «НІССХ ім. М.М. Амосова НАМНУ» за період 2011-2014 рр. пренатально спостерігались 222 вагітні, а постнатально - 169 новонароджених із гемодинамічно значущими вродженими вадами серця, 3 них 29 дітей 3 патологією дуги аорти. Провідна роль у діагностиці вроджених вад серця та надання своєчасної кардіохірургічної допомоги новонародженому належала фетальній ехокардіографії. 3 метою уточнення діагнозу та визначення подальшої тактики усі малюки були проконсультовані у ДУ «НІССХ ім. М.М. Амосова». У випадку виявлення випадків ізольованої критичної коарктації аорти або гіпоплазії дуги аорти, новонароджені в першу добу та навіть години життя були госпіталізовані у відділення вроджених вад серця.

Результати. У 18 (46,2\%) малюків гіпоплазія дуги аорти була складовою синдрому гіпоплазії лівих відділів серця.

Висновки. При діагностуванні або підозрі на патологію дуги аорти у плода (ізольовану або поєднану з іншими вадами серця) обов'язкове ставлення до відома неонатологів сприяє своєчасному встановленню діагнозу та надання, у разі необхідності, кардіохірургічної допомоги ще до розвитку ускладнень.

Ключові слова: плід, новонароджений, аномалія дуги аорти, пренатальна ЕхоКГ, кардіохірургія.

PERINATOLOGIYA I PEDIATRIYA.2015.2(62):16-21; doi10.15574/PP.2015.62.16

Congenital anomalies of the aortic arch: perinatal management

I.S. Lukianova1, Y.P. Truba2, G.F. Medvedenko1, O.D. Zhadan1, L.A. Ivanova2

$1 \mathrm{SI}$ «Institute of Pediatrics, Gynecology and Obstetrics NAMN of Ukraine», Kyiv, Ukraine

$2 \mathrm{SU}$ «N.M. Amosov National Institute of Cardiovascular Surgery NAMS of Ukraine», Kiev, Ukraine

Purpose - according to the literature data and analysis of the own results

to make recommendations for improvement of the detection of abnormalities of the aorta with the aim of timely cardiac care.

Patients and methods. For the period of 2011-2014 at SI «IPOG NAMSU» and SI «NICS NAMSU» were observed 222 pregnant women prenatally and 169 infants with hemodynamically significant CHD postnatally, including 39 children with the pathology of the aortic arch. The leading role in the diagnosis of congenital heart disease and providing timely cardiac care to the newborn belonged to fetal echocardiography (ECHO). All the children were consulted at SI «NICS NAMSU» in order to clarify the diagnosis and determine the further management. In all cases of isolated critical coarctation of the aorta or aortic arch hypoplasia, newborns in the first days or even hours of life were hospitalized in the department of congenital heart defects. Results. In $18(46.2 \%)$ neonates hypoplasia of the aortic arch was part of the hypoplastic left-heart syndrome.

Conclusion. After diagnosis or suspicion of pathology of the aortic arch in the fetus (alone or in combination with other anomalies of the heart) the compulsory notification of neonatologists facilitates timely diagnosis and the providing, if necessary, cardiac surgery before the development of complications. Key words: fetus, neonate, anomaly of the aortic arch, prenatal echocardiography, cardiac surgery.

\section{Сведения об авторах:}

Лукьянова И.С. - д.мед.н, проф., руководитель отделения лучевой диагностики и пренатальной кардиологии ДУ «ИПАГ НАМН Украины». Адрес: г. Киев, ул. П. Майбороды, 8;тел. 483-14-46

Труба Я.П. - к.мед.н, зав. отделением хирургического лечения врожденных пороков сердца у новорожденных и детей младшего возраста ГУ «НИССХ им. Н.М. Амосова НАМН Украины». Адрес: г. Киев, ул. Н. Амосова, 6; ГСП-680; тел. (044) 275-42-33.

Медведенко Г.Ф. - к.мед.н, вед.н.сотр. отделения лучевой диагностики и пренатальной кардиологии

ГУ «НИССх им. Н.М. Амосова НАМН Украины» Адрес: г. Киев, ул. Н. Амосова, 6; ГСП-680.

Жадан Е.Д. - врач ультразвуковой диагностики отделения лучевой диагностики и пренатальной кардиологии ГУ «ИПАГ НАМН Украины». Адрес: г. Киев, ул. Н. Амосова, 6; ГСП-680.

Иванова Л.А. - к.мед.н, врач отделения реанимации новорожденных ГУ «НИССХ

им. Н.М. Амосова НАМН Украины». Адрес: г. Киев, ул. Н. Амосова, 6; ГСП-680.

Статья поступила в редакцию 10.04.2015 г. 


\title{
І.Ю. Гордієнко, Т.В. Нікітчина, О.О. Ващенко, О.М. Тарапурова, А.В. Величко, К.В. Раченко Характеристика кількісних змін статевих хромосом у плодів жінок групи високого ризику
}

ДУ «Інститут педіатрії, акушерства і гінекології НАМН України», м. Київ, Україна

\author{
PERINATOLOGIYA I PEDIATRIYA.2015.2(62):22-24;doi10.15574/PP.2015.62.22
}

Кількісні аномалії статевих хромосом сумісні з постнатальним розвитком та інколи діагностуються лише в пубертатному періоді.

Мета - проаналізувати результати пренатальної цитогенетичної діагностики кількісних змін статевих хромосом у плодів вагітних жінок групи високого ризику

Пацієнти та методи. Пренатальні ультразвукові дослідження з наступним каріотипуванням проводилися в 4354 плодів вагітних жінок групи високого ризику. Для дослідження біоптата хоріона та плаценти використовувався прямий метод обробки ворсин, а для лімфоцитів пуповинної крові напівмікрометод.

Результати. Зміни кількості гоносом визначалися в 46 (1,06\%) випадках. Найчастіше діагностувалася моносомія X - 26 (56,52\%), також серед аномалій гоносом були: трисомія X хромосоми - 11 (23,91\%), каріотип XXY - 6 (13,04\%), дисомія Y хромосоми - 3 (6,52\%) випадки.

Висновки. При відсутності однієї з гоносом вади розвитку плода зустрічались у 9 разів частіше, ніж при наявності надлишкової $X$ чи $Y$ хромосоми. Ключові слова: каріотип, гоносоми, плід, пренатальна діагностика.

\section{Вступ}

V ромосомні захворювання - значна група вродже-

$\chi$ них спадкових захворювань, які виникають унаслідок хромосомних або геномних мутацій. Частота аномалій статевих хромосом (гоносом), за даними Liao C. et al. (2013), становить 0,9\% і найвища серед усіх хромосомних аномалій, діагностованих пренатально в життєздатних плодів [8].

При зміні кількості або структури гоносом клінічно спостерігаються ознаки, характерні для відомих гоносомних синдромів - Тернера, Клайнфельтера, трисомії X, дисомії $\mathrm{Y}$.

Синдром Тернера пов'язаний з повною $(45, \mathrm{X})$ або мозаїчною формою (45,X/46,XX; 45,X/46,XY) моносомії X хромосоми, а також з їі структурними аномаліями: делеції короткого або довгого плеча $\mathrm{X}$ хромосоми $(46, \mathrm{X}, \operatorname{del}(\mathrm{Xq})$ 46,X,del(Xp)), ізохромосоми (46,X,iso $(\mathrm{Xq}))$, кільцеві хромосоми (46,X,r(X)). Плоди/жінки з повною моносомією $\mathrm{X}$ хромосоми мають більш складні аномалії, ніж носії мозаїчних і структурних порушень в одній з X-хромосом. Синдром Тернера - єдина вітальна форма моносомії, однак більшість плодів гине антенатально і тільки 1\% доживає до терміну фізіологічних пологів. Тому прогноз для плодів із моносомією X, виявлених пренатально, значно гірший за прогноз для новонароджених [6].

Синдроми, обумовлені збільшенням кількості гоносом, як Клайнфельтера (47,XXY; 48,XXXY; 48,XYYY; 48,XXYY; 49,XXXXY; 49,XXXYY), полісомії X (47,XXX; 48,XXXX; $49, \mathrm{XXXXX)} \mathrm{та} \mathrm{дисомії} \mathrm{Y} \mathrm{(47,XYY),} \mathrm{за} \mathrm{винятком} \mathrm{легкого} \mathrm{сту-}$ пеня розумової відсталості, не мають більше визначених і чітких ознак. Однак подальше зростання кількості Х хромосом у каріотипі призводить, як правило, до більшої затримки розумового розвитку, ширшого спектра вад і мікроаномалій.

Більшість аномалій гоносом сумісні з постнатальним розвитком, але впливають на процеси дозрівання гамет і часто призводять до безпліддя. Основні клінічні ознаки з'являються лише в препубертатному та пубертатному періоді, а точна і своєчасна діагностика ускладнюється наявністю тканинного мозаїцизму та значною кількістю мозаїчних форм, які змінюють картину. Тільки 10\% аномалій гоносом виявляються пренатально, ще 25\% діагностуються в дитинстві та пубертатному періоді, а 65\% залишаються нерозпізнаними [9].
Mema роботи - проаналізувати результати пренатальної цитогенетичної діагностики кількісних змін статевих хромосом у плодів вагітних жінок групи високого ризику.

\section{Матеріали та методи дослідження}

Пренатальні ультразвукові дослідження (УЗД) у реальному масштабі часу проводились на апаратах ACCUVIX V20EX-EXP, ACCUVIX V10LV-EX, Aloka SSD - 630, HDI 4000. Інвазивні процедури виконувались за стандартом відповідно до показань [3].

Для цитогенетичного дослідження біоптата хоріона та плаценти використовувався прямий метод фіксації [Flori E. et al., 1985; Баранов В.С. и др., 1990] з власною модифікацією. Культивування та фіксація лімфоцитів пуповинної крові проводилися 3 використанням напівмікрометода [Hungerford D. et al., 1965]. Препарати хромосом аналізувалися за допомогою світлових мікроскопів BX51 (Olympus) та BX53 (Olympus) на збільшенні х10000. Запис результату аналізу проводився за міжнародною номенклатурою (ISCN, 2013).

Каріотипи з порушенням кількості статевих хромосом визначалися нами у 46 (1,06\%) з 4354 обстежених плодів вагітних жінок групи високого ризику.

Матеріалом для дослідження хромосомного набору плода в 15 (32,61\%) випадках був біоптат хоріона. Пренатальні цитогенетичні дослідження проводилися у зв'язку з показаннями

- вроджені вади розвитку (ВВР) плода - 7 (46,67\%) випадків;

- УЗ-маркери хромосомної патології плода 4 (26,67\%) випадки;

- біохімічні маркери хромосомної патології плода 3 (20\%) випадки;

- віковий критерій вагітної та біохімічні маркери хромосомної патології плода - 1 (6,67\%) випадок.

У більшості випадків - 20 (43,48\%) - досліджувався біоптат плаценти. Показаннями для проведення пренатальної цитогенетичної діагностики в цих випадках були:

- ВВР плода - 11 (55\%) випадків;

- УЗ-маркери - 1 (5\%) випадок;

- УЗ-маркери в поєднанні з біохімічними маркерами 1 (5\%) випадок; 
Аналіз розподілу показань для каріотипування плода

при виявленні кількісних аномалій гоносом у плодів вагітних жінок групи високого ризику

\begin{tabular}{|c|c|c|c|c|}
\hline \multirow{2}{*}{ Показання } & \multicolumn{4}{|c|}{ Каріотип } \\
\hline & $45, X$ & $47, X X X$ & $47, X X Y$ & $47, X Y Y$ \\
\hline BBP & 18 & 1 & 1 & - \\
\hline УЗ-маркери & 4 & - & 1 & - \\
\hline Біохімічні маркери & 3 & 3 & 3 & 3 \\
\hline УЗ-маркери та біохімічні маркери & 1 & - & - & - \\
\hline Вік & - & 6 & - & - \\
\hline Вік та біохімічні маркери & - & 1 & 1 & - \\
\hline Усьoro & 26 & 11 & 6 & 3 \\
\hline
\end{tabular}

- біохімічні маркери хромосомної патології плода 6 (30\%) випадків;

- віковий критерій матері - 1 (5\%) випадок.

Сумісно біоптат плаценти і пуповинна кров досліджувались у 9 (19,57\%) випадках:

- віковий критерій матері - 3 (33,33\%) випадки;

- віковий критерій матері в поєднанні з біохімічними маркерами - 1 (11,11\%) випадок;

- біохімічні маркери хромосомної патології плода 3 (33,33\%) випадки;

- ВВР плода - 2 (22,23\%) випадки.

Також за віковим критерієм матері досліджувалася пуповинна кров та біоптат хоріона і пуповинна кров (по 1 випадку - 2,17\%).

\section{Результати дослідження та їх обговорення}

У відділенні медицини плода ДУ «ІПАГ НАМН України» при проведенні пренатальної цитогенетичної діагностики зміни кількості гоносом визначалися в 1,06\% випадків серед 4354 обстежених плодів жінок групи високого ризику. Отримані результати відповідають даним Liao C. et al. (2013), за якими, частота аномалій гоносом становить $0,9 \%$ [8].

Найчастіше діагностувалася моносомія X 26 (56,52\%), також серед аномалій гоносом були: трисомія $\mathrm{X}$ хромосоми - 11 (23,91\%), каріотип XXY хромосоми $6(13,04 \%)$, дисомія $\mathrm{Y}$ хромосоми $-3(6,52 \%)$ випадки.

У нашому дослідженні моносомія $\mathrm{X}$ діагностувалася в 0,6\% обстежених плодів, за даними Ataman E. et al. (2012), цей показник становить 0,48\% [4]. Синдром характеризується варіабельністю фенотипових проявів. Показання для каріотипування плода відображені в таблиці. Типовою ознакою, особливо летальних форм моносомії X, $\epsilon$ шийні цистогігроми, які спостерігаються у 82,1\% плодів 3 аномаліями розвитку [10]. У нашому дослідженні кістозні гігроми відмічалися в 11 (61,11\%) з 18 плодів iз BВP. Характерними ознаками є шийний птеригіум та генералізований підшкіряний лімфатичний набряк, крім того, можуть визначатися гіпертелоризм, коротка шия, укорочена грудна клітка, затримка розвитку плода [2]

Трисомія X визначалася в 11 (0,5\%) з 2194 плодів жіночої статі. Частота цієї аномалії серед новонароджених дівчат становить $0,1 \%$ [1]. Основним показанням для визначення каріотипа плода $є$ вік вагітної (табл.). Зазвичай ця хромосомна патологія не супроводжується вадами розвитку. Слід зазначити, що в нашому дослідженні при такому каріотипі під час проведення УЗД виявлено 1 випадок вродженої вади серця плода.
Дисомія Х при чоловічому каріотипі (синдром Клайнфельтера) - найчастіша форма гоносомної патології у чоловіків i, за даними Gruchy N. et al. (2011), виявляється з частотою $0,17 \%$ пренатально та $0,2 \%$ у новонароджених хлопчиків, що вказує на низький рівень невиношування в даній групі [7]. У нашому дослідженні каріотип XXY визначався у $6(0,28 \%)$ з 2160 обстежених плодів чоловічої статі. Основним показанням для визначення каріотипа були змінені біохімічні маркери сироватки крові вагітних. Хоча дана патологія не має типових вад розвитку плода, показаннями для каріотипування також є ВВР обличчя плода та УЗ-маркери хромосомної патології (по 1 випадку), визначені під час УЗД (табл.).

Ще один тип аномалій гоносом, який зустрічається тільки у чоловіків, - це дисомія Y хромосоми, виявлена нами у $3(0,14 \%)$ з 2160 обстежених плодів чоловічої статі. Частота дисомії Y становить $0,1 \%$ серед новонароджених хлопчиків. Аномалії розвитку при УЗД відсутні. Підставою для каріотипування плода у всіх випадках є змінені біохімічні маркери сироватки крові вагітних.

У нашому дослідженні вік вагітної був показанням для каріотипування в 7 (63,64\%) з 11 випадків визначеної трисомії X, та в 1 (16,67\%) із 6 - при діагностиці каріотипу XXY, що співпало з даними Boyd P.A. et al. (2010) та ChihPing Chen et al. (2014). За їх даними, частота трисомії X хромосоми підвищується зі зростанням віку вагітної, частота синдрому Клайнфелтера залежить від віку вагітної меншою мірою, водночас частота дисомії Y [5] та моносомії $\mathrm{X}$ не пов'язана з віком матері [6].

Як відомо, біохімічний скринінг розроблений для виявлення вагітних жінок групи високого ризику народження дітей з синдромом Дауна, однак зміна рівня біохімічних маркерів сироватки крові вагітних спостерігається і при інших хромосомних аномаліях. У нашому дослідженні змінені біохімічні маркери сироватки крові вагітних при виявленні дисомії Y хромосоми спостерігались у $100 \%$ випадків, при каріотипі XXY - 66,66\%, трисомії X хромосоми - 36,36\%, моносомії $\mathrm{X}-15,38 \%$. На противагу цьому, Vaknin Z. et al. (2008) у своєму дослідженні звертав увагу на зміну результатів біохімічного скринінга при синдромі Тернера, меншою мірою - при XYY і повній відсутності чутливості при інших аномаліях гоносом [11].

\section{Висновки}

Аналіз 46 випадків кількісних аномалій гоносом показав, що при відсутності однієї з гоносом вади розвитку плода при УЗД зустрічались у 9 разів частіше, ніж при наявності надлишкової $\mathrm{X}$ чи $\mathrm{Y}$ хромосоми. 


\section{ЛITЕРАТУРA}

1. Атраментова Л.А. Введение в психогенетику [Электронный ресурс]: учеб. пос. / Л.А. Атраментова, О.В. Филипцова. 3-е изд., стер. - М.: Флинта, 2014. - 472 с.

2. Ультразвукові маркери хромосомних та структурних аномалій плода в другому триместрі вагітності: метод. рекомендації / І.Ю. Гордієнко, О.М. Тарапурова, Т.В. Нікітчина [та ін.]; МОЗ України, ДУ «Центральний методичний кабінет з вищої медичної освіти МОЗ України». - Київ-Харків, 2013. - 36 с.

3. Гордиенко И.Ю. Аспирация ворсин хориона и плаценты / И.Ю. Гордиенко // Врожденные пороки развития: пренатальная диагностика и тактика / под ред. Б.М. Петриковского, М.В. Медведева, Е.В. Юдиной. - М.: РАВУЗДПГ, Реальное Время, 1999. - С. 215-230.

4. The rate of sex chromosome aneuploidies in prenatal diagnosis and subsequent decisions in Western Turkey / E. Ataman, O. Cogulu, A. Durmaz [et al.] // Genet. Test Mol. Biomarkers. - 2012. № 16 (2). - P. 150-153.

5. Sex chromosome trisomies in Europe: prevalence, prenatal detection and outcome of pregnancy / P.A. Boyd, M. Loane, E. Garne [et al.] // Eur. J. of Hum. Genetics. - 2011. - Vol. 19 (2). - P. 231-234.
6. Chih-Ping Chen Prenatal Sonographic Features of Turner Syndrome Chen Chih-Ping, Chien Shu-Chin // Prenat. Diagn. - 2014. Vol. 34 (12). - P. 1133-1138.

7. Pregnancy outcomes in 188 French cases of prenatally diagnosed Klinefelter syndrome / N. Gruchy, F. Vialard, M. Decamp [et al.] // Hum. Reprod. - 2011. - № 26 (9). - P. 2570-2575.

8. Liao C. Prenatal diagnosis of sex chromosome aneuploidies: experience at a mainland Chinese hospital / C. Liao, C.X. Yi, D.Z. Li // J. Obstet. Gynaecol. - 2013. - № 33 (8). - P. 827-829.

9. Incidental Prenatal Diagnosis of Sex Chromosome Aneuploidies: Health, Behavior, and Fertility / J.J.P.M. Pieters, A.J.A. Kooper A. Geurts van Kessel [et al.] // ISRN Obstetrics and Gynecology (Online). - 2011. - Article ID 807106. - 10 p.

10. Prenatal management, pregnancy and pediatric outcomes in fetuses with septated cystic hygroma / C.Y. Sanhal, I. Mendilcioglu, M. Ozekinci [et al.] // Braz. J. Med. Biol. Res. - 2014. - Vol. 47 (9). - P. 799-803.

11. Prenatal diagnosis of sex chromosome abnormalities: the 8-year experience of a single medical center / Z. Vaknin, O. Reish, I. Ben-Ami [et al.] // Fetal. Diagn. Ther. - 2008. - Vol. 23 (1). - P. 76-81.

\section{Характеристика количественных изменений половых хромосом у плодов женщин группы высокого риска И.Ю. Гордиенко, Т.В. Никитчина, О.А. Ващенко, Е.Н. Тарапурова, А.В. Величко, Е.В. Раченко}

ГУ «Институт педиатрии, акушерства и гинекологии НАМН Украины», г. Киев, Украина

Количественные аномалии половых хромосом совместимы с постнатальным развитием и иногда диагностируются только в пубертатном периоде.

Цель - проанализировать результаты пренатальной цитогенетической диагностики количественных изменений половых хромосом у плодов беременных женщин группы высокого риска.

Пациенты и методы. Пренатальные ультразвуковые исследования с последующим кариотипированием проводились у 4354 плодов беременных женщин группы высокого риска. Для исследования биоптата хориона и плаценты использовался прямой метод обработки ворсин, а для лимфоцитов пуповинной крови - полумикрометод.

Результаты. Изменения количества гоносом определялись в 46 (1,06\%) случаях. Чаще всего диагностировалась моносомия $X$ хромосомы 26 (56,52\%), также среди аномалий гоносом были: трисомия X хромосомы - $11(23,91 \%)$, кариотип XXY - 6 (13,04\%), дисомия Y хромосомы $3(6,52 \%)$ случая.

Выводы. При отсутствии одной из гоносом которой врожденные пороки развития плода встречались в 9 раз чаще, чем при наличии дополнительной $X$ или $\mathrm{Y}$ хромосомы.

Ключевые слова: кариотип, гоносомы, плод, пренатальная диагностика.

PERINATOLOGIYA I PEDIATRIYA.2015.2(62):22-24; doi10.15574/PP.2015.62.22

Characteristics of quantitative changes of sex chromosomes in fetuses of high-risk pregnant women

I.Yu. Gordienko, T.V. Nikitchina, 0.0. Vaschenko, O.M. Tarapurova, A.V. Velychko, K.V. Rachenko

SI «Institute of Pediatrics, Gynecology and Obstetrics NAMS of Ukraine», Kyiv, Ukraine

Quantitative changes of sex chromosomes compatible with postnatal development and diagnosed sometimes only during adolescence.

Purpose - the analysis of the results of prenatal cytogenetic diagnosis of quantitative changes of gonosomes in fetuses of high-risk pregnant women.

Patients and methods. Prenatal ultrasound examination of 4354 fetuses of high-risk pregnant women was performed, followed by fetal karyotyping. For cytogenetic analysis of biopsy samples a direct method of processing the villi was used and for fetal blood — halfmicromethod.

Results. A total of $46(1.06 \%)$ cases with quantitative changes of gonosomes were identified. Monosomy X was the most frequently diagnosed -26 (56.52\%) cases, another honosome anomalies were: X chromosome trisomy - $11(23.91 \%), X X Y$ karyotype $-6(13.04 \%), Y$ chromosome dysomy - $3(6.52 \%)$ cases Conclusions. The absence of one of gonosomes cause congenital malformations 9 times more frequently, than the presence of extra $X$ or $Y$ chromosome. Key words: karyotype, fetus, gonosomes, prenatal diagnosis.

Сведения об авторах:

Гордиенко Ирина Юрьевна - д.мед.н., проф., зав. отделением медицины плода ГУ «ИПАГ НАМН Украины».

Адрес: г. Киев, ул. П. Майбороды, 8; тел. (044) 483-92-39; e-mail: VMP @i.ua.

Никитчина Татьяна Витальевна - к.биол.н., ст.н.сотр. отделения медицины плода ГУ «ИПАГ НАМН Украины».

Адрес: г. Киев, ул. П. Майбороды, 8; тел. (044) 483-92-39.

Ващенко Оксана Алексеевна - м.н.сотр. отделения медицины плода ГУ «ИПАГ НАМН Украины».

Адрес: г. Киев, ул. П. Майбороды, 8; тел. (044) 483-92-39.

Тарапурова Елена Николаевна - к.мед.н., вед.н.сотр. отделения медицины плода ГУ «ИПАГ НАМН Украины».

Адрес: г. Киев, ул. П. Майбороды, 8; тел. (044) 483-92-39.

Величко Андрей Васильевич - н.сотр. отделения медицины плода ГУ «ИПАГ НАМН Украины».

Адрес: г. Киев, ул. П. Майбороды, 8; тел. (044) 483-92-39.

Раченко Катерина Владимировна - лаборант первой категории отделения медицины плода

ГУ «ИПАГ НАМН Украины». Адрес: г. Киев, ул. П. Майбороды, 8; тел. (044) 483-92-39.

Статья поступила в редакцию 12.05.2015 г. 


\title{
І.А. Жабченко, Г.Є. Яремко, І.С. Ліщенко, О.М. Дзюба, Т.М. Коваленко Ехографічні особливості фетоплацентарного комплексу жінок із переношеною та пролонгованою вагітністю
}

\author{
ДУ «Інститут педіатрії, акушерства і гінекології НАМН України», м. Київ, Україна
}

\author{
PERINATOLOGIYA I PEDIATRIYA.2015.2(62):25-28;doi10.15574/PP.2015.62.25
}

\begin{abstract}
Мета - встановити перинатальні ризики в жінок із переношеною та пролонгованою вагітністю за даними ультразвукового та допплерівського дослідження плода і фетоплацентарного комплексу.

Пацієнти та методи. Антенатально напередодні пологів проведено ехографічне дослідження фетоплацентарного комплексу у 54 вагітних із переношеною та пролонгованою вагітністю і у 22 жінок із фізіологічною гестацією.

Результати. Отримані результати комплексного ультразвукового моніторингу стану плода та фетоплацентарного комплексу напередодні пологів свідчать, що ознаки плацентарної диссфункції виявлено у 100\% вагітних із переношеною вагітністю та у $82 \%$ жінок із пролонгованою гестацією, що втричі вище, ніж у жінок із доношеною вагітністю (31\%). Результати дослідження свідчать про перинатальні ризики вже після 40 тиж. гестації у жінок із пролонгованою вагітністю.

Висновки. Консервативно-очікувальна тактика 3 проведенням ультразвукового моніторингу стану плода та фетоплацентарного комплексу при вагітності терміном понад 40-41 тиж. дала змогу завершити вагітність самостійними пологами в 74\% обстежених із переношеною вагітністю та пролонгованою гестацією і народити живих дітей із задовільною оцінкою за шкалою Апгар. Антенатальний ехографрічний моніторинг змін у фетоплацентарному комплексі дозволив виявити перинатальні ризики у вагітних із переношеною вагітністю та обрати адекватну тактику ведення вагітності та пологів.
\end{abstract}

Ключові слова: ехографія, переношена, пролонгована вагітність, плацентарна диссфункція, плід.

\section{Вступ}

$\Pi$ рогрес у сучасній перинатології призвів до необхідності виділення нових проблем, пов'язаних із гестаційним процесом та антенатальною охороною плода, оскільки на сучасному етапі існує тенденція до збільшення кількості вроджених захворювань, детермінованих морфофункціональними порушеннями у фетоплацентарній системі. Серед цих проблем значне місце посідає плацентарна дисфункція (ПД), що, як правило, супроводжується дистресом і затримкою внутрішньоутробного росту плода та є одним із найбільш частих і впливових чинників перинатальної захворюваності та смертності. Загальновизнано, що ПД - це симптомокомплекс, який супроводжує практично всі ускладнення вагітності.

Частота ПД у пацієнток із прееклампсією становить 66,3\%, з переношеною вагітністю (ПВ) - 36,3\%, із невиношуванням в анамнезі - 46\%, із вірусним та бактеріальним інфікуванням - 50-55\% [2].

Високий відсоток ПД при ПВ свідчить про те, що ця патологія залишається серйозною проблемою сучасного акушерства.

Частота ПВ у популяції становить 8-10\% і не має тенденції до зниження. Водночас, перинатальна смертність при ПВ сягає 1,9\%, а неонатальна захворюваність - 29,0\%, що в 6 разів вище, ніж при доношеній вагітності. Це пов'язано з низькою стійкістю плода до гіпоксії внаслідок більшої зрілості головного мозку та зменшенним надходженням до нього кисню через морфологічні зміни в плаценті при ПВ. У результаті підвищується частота синдрому меконіальної аспірації та дистрес-синдрому плода в пологах, які обумовлюють високий рівень перинатальної захворюваності та смертності. Смертність при меконіальній аспірації досягає 60\%, а перенесена гіпоксія призводить до перинатальних уражень центральної нервової системи, які становлять 60-80\% від усіх захворювань нервової системи дитячого віку [2, 6, 15].

За даними ретроспективного аналізу історій пологів, проведеного в ДУ «Інститут педіатрії, акушерства і гінекології НАМН України» за 2008-2012 рр., перебіг вагітності і пологів у жінок із переношуванням ускладнюється ПД (45\%), гострим дистресом плода (19\%), аномаліями пологової діяльності (24\%), несвоєчасним вилиттям амніотичної рідини - AP (33\%), які обумовлюють високу частоту абдомінального розродження (40\%), значний відсоток пологового травматизму (45\%) та незадовільний стан плода при народженні (23\%).

У дослідженнях останніх років значна увага надається порушенню функції плаценти при ПВ, яким пояснюється таке явище, як дистрес плода. Зміни, що спостерігаються в плаценті при ПВ, є вторинними, однак у подальшому вони можуть відігравати важливу роль у стероїдогенезі, стані плода та розвитку пологової діяльності. При ПВ порушується рівновага гормональних і гуморальних систем організму жінки, що, своєю чергою, впливає на формування пологової домінанти та своєчасне настання пологів [3, 13].

Велике значення для антенатальної диференційної діагностики пролонгованої вагітності та ПВ мають дані, отримані за допомогою ультразвукового дослідження (УЗД). Ехоскопічна діагностика стану плода та навколоплодового середовища при ПВ має принципове значення для вибору терміну і методів розродження та поліпшення перинатальних наслідків. На теперішній час накопичено певний досвід ультразвукової діагностики ПВ, що дає змогу з високим ступенем вірогідності діагностувати дану патологію.

Ехоскопічні ознаки ПВ такі: виражені структурні зміни в плаценті (петрифікати, кісти); прогресуюче маловоддя; відсутність приросту біометричних параметрів плода; потовщення кісток черепу плода; ознаки хронічного дистресу плода. Найбільш достовірною ознакою оцінки росту плода та визначення терміну вагітності є біпарієтальний розмір (БПР) голівки плода. При ПВ немає суттєвого збільшення БПР після 40 тиж. вагітності, тоді як при пролонгованій вагітності він прогресивно зростає. При ехографічному зображенні голівки у переношеного плода спостерігається потовщення кісток черепу, тоді як ця ознака відсутня при пролонгуванні вагітності. При ПВ, у противагу пролонгованій, маса плода після 42 тиж. вагітності не збільшується, що обумовлене дисфункцією плаценти $[5,7]$.

У структурі перинатальної захворюваності та смертності при ПВ одне з провідних місць займає патологія функції дихання при народженні, яка проявляється 
у вигляді двох основних дистрес-синдромів - дихальної недостатності та аспірації навколоплодовими водами за умов переношування. При ПВ у плода виникає симптомокомплекс «перезрілості», основними патогенетичними механізмами якого є прогресуюче старіння плаценти, розвиток плацентарної дисфункції, маловоддя i, як наслідок, дистресу плода. Ці процеси призводять до несвоєчасного виникнення дихальних рухів плода в анте- та інтранатальному періодах, наслідком чого можуть бути аспірація навколоплодовими водами та асфіксія плода. Дистрес плода при запізнілих пологах зустрічається у 3-8 разів частіше, ніж при своєчасних [5].

На думку більшості авторів, порушення життєдіяльності плода при ПВ, насамперед, пов'язане зі змінами в плаценті, що підтверджено гістологічними та гістохімічними дослідженнями $[7,16]$.

Невідповідність ступеня зрілості плаценти гестаційному терміну супроводжується високим ризиком розвитку перинатальних ускладнень. Найбільш часто при розладах у системі мати-плаценти-плід відзначаються такі ознаки, як випередження ступеня зрілості плаценти відносно терміну гестації та гіпоплазія плаценти, що розцінюється як прогностично несприятливі ознаки щодо стану плода $[1,10]$.

Істотне значення для визначення ПД має кількісне визначення об'єму навколоплодових вод. Джерелом вод є ультрафільтрат плазми крові матері, амніотичні оболонки і нирки плода, що продукують 600-800 мл сечі на добу Поява маловоддя пов'язана як із порушенням продукції вод, так і зі зниженням секреції фетальної сечі внаслідок розладів функції нирок плода.

Маловоддя, яке найбільш точно діагностується при ехографічному обстеженні, визначається шляхом підрахунку амніотичного індексу, що в нормі має перевищувати 8. Зниження рівня АР наприкінці вагітності потребує активної акушерської тактики. Вираженість маловоддя корелює 3 негативними перинатальними наслідками та є раннім симптомом ПВ. Забарвлення амніотичної рідини в зелений або жовтий колір свідчить, головним чином, про дистрес плода та необхідність термінового втручання $[11,13]$.

Остаточно діагноз ПВ підтверджують після пологів шляхом оцінки та огляду новонародженого і виявлення ознак перезрілості, а також за наявності макроскопічних змін у плаценті. При пролонгованій вагітності із вказаних ознак наявні тільки великі розміри плода, ознаки перезрілості відсутні $[8,13]$.

Отже, враховуючи те, що при біохімічному, гормональному, функціональному, морфологічному, цитологічному та інших дослідженнях при доношеній та пролонгованій вагітності статистично достовірної різниці багатьох показників не отримано, є підстави розглядати пролонговану вагітність, як своєрідний фізіологічний стан. Слід підкреслити, що патогномонічних ознак переношеного плода немає, а є синдром, на основі якого можна діагностувати ПВ. Усі перераховані методи дослідження, з різним ступенем вірогідності, дозволяють оцінити ступінь зрілості плода, його функціональний стан, функцію матково-плацентарної системи. На основі цих даних, враховуючи хронологічне переношування, можна встановити діагноз ПВ чи пролонгованої вагітності $[8,13]$.

Mema роботи - встановити перинатальні ризики в жінок із ПВ та пролонгованою вагітністю за даними УЗД та допплерівського дослідження плода і фетоплацентарного комплексу.

\section{Матеріали та методи дослідження}

3 метою розробки прогностичних критеріїв перинатальних наслідків, алгоритму обстеження та тактики розродження ми провели проспективне комплексне УЗД у 76 вагітних, яких розподілили на три групи: 1-а група (основна) 20 вагітних із терміном гестації 42-43 тиж., в яких відбулися запізнілі пологи; 2-а група (порівняння) - 34 вагітні із терміном гестації 40-41 тиж.; 3-я група (контрольна) - 22 жінки 3 доношеною (39-40 тиж.) неускладненою вагітністю та терміновими пологами. Ехографію плода та фетоплацентарного комплексу провели за допомогою ультразвукового діагностичного приладу Simens ACUS0N X300.

Комплексне УЗД напередодні терміну пологів включало фетометрію, плацентографію, плацентометрію, оцінку кількості та якості навколоплодових вод. Відповідність результатів фетометрії порівнювали з нормативним для даного терміну гестації. Структуру плаценти оцінювали як відповідну їі стану в нормі у випадку, коли ступінь їі зрілості і товщина відповідала терміну вагітності, були відсутні патологічні включення в її структурі, а розташування плаценти було нормальним [14]. За віком та паритетом групи обстежених жінок були репрезентативними.

\section{Результати дослідження та їх обговорення}

При інтерпретації даних ультразвукової ехографії ми виходили з того, що отримана інформація відображає стан фетоплацентарної системи та її компенсаторних реакцій на момент огляду, оскільки фетометричні дані, структура плаценти та об'єм навколоплодових вод визначаються, як «маркери стабільності фетоплацентарної системи». На думку деяких дослідників, гіпоплазія та передчасне «старіння» плаценти є результатом глибоких біологічних порушень у трофобласті, а гіперплазія та деструктивні зміни можуть бути ознакою інфекційних процесів $[4,9,12]$.

При аналізі даних фетометрії ми звернули увагу на відповідність БПР голівки плода терміну вагітності. За нашими даними, прогресуюче збільшення БПР голівки плода з 9,2 см у 40 тиж. вагітності до 9,5 см у 41-42 тиж. гестації спостерігалось у 60,0\% жінок 1-ї групи та у $82,0 \%$ жінок 2-ї групи. Суттєвого збільшення БПР голівки плода напередодні пологів при динамічному УЗД не було у 40,0\% жінок 1-ї групи та у 18,0\% вагітних із пролонгованою вагітністю, що може свідчити про ознаки перезрілості в плода. У вагітних 3-ї групи даний показник відповідав нормативним для даного терміну гестації.

За даними деяких авторів, про ПВ при УЗД свідчать такі ехографічні ознаки: плацента III ступеня зрілості

Ультразвукові ознаки плацентарної дисфункції в обстежених вагітних, абс. (\%)

Таблиия

\begin{tabular}{|l|c|c|c|}
\hline \multicolumn{1}{|c|}{ Показник } & \multicolumn{3}{|c|}{ Група обстежених вагітних } \\
\cline { 2 - 4 } & $\mathbf{1 - a}(\mathbf{n = 2 0})$ & $\mathbf{2 - a}(\mathbf{n = 3 4 )}$ & $\mathbf{3 - я}(\mathbf{n = 2 2})$ \\
\hline ІІІ ступінь зрілості плаценти з петрифікатами & $6(30,0)$ & $8(23,5)$ & $5(22,7)$ \\
\hline Маловоддя (АІ<8) & $5(25,0)$ & $6(17,6)$ & $2(9,0)$ \\
\hline Гіпоплазія плаценти & $5(25,0)$ & $7(20,6)$ & - \\
\hline Підвищена ехогенність амніотичної рідини & $4(20,0)$ & $4(11,8)$ & - \\
\hline Усього & $20(100,0)$ & $25(73,5)$ & $7(31,8)$ \\
\hline
\end{tabular}


3 петрифікатами; маловоддя; підвищена ехогенність навколоплодових вод. На наявність пролонгованої вагітності вказують такі ознаки: зрілість плаценти II-III ступеня та нормальна кількість вод. Крім того, про ПВ може свідчити прогресуюча гіпоплазія плаценти. Прогностично несприятливим для плода щодо розвитку перинатальних ускладнень $€$ швидке зменшення кількості АР. Результати проведеної ехографічної оцінки плаценти та навколоплодових вод в обстежених вагітних представлені в таблиці.

За наведеними даними, у 100\% вагітних із ПВ мали місце ті чи інші ознаки ПД. Поєднання таких УЗ-ознак, як маловоддя, III ступінь зрілості плаценти та підвищення ехогенності АР, спостерігалося у 75,0\% цих жінок. У жінок 2-ї групи з пролонгованою вагітністю теж виявлялись значні зміни у фетоплацентарному комплексі. Так, поєднання маловоддя, перезрілості плаценти та підвищеної ехогенності АР відмічалося у 53\% жінок із пролонгованою вагітністю, що свідчить про ознаки ПД вже на 41-му тижні гестації. У жінок групи контролю ознаки ПД були лише в третини обстежених.

Проведена УЗ плацентометрія виявила прогресуюче зменшення товщини плаценти у 25,0\% вагітних 1-ї групи та у $20 \%$ жінок 2-ї групи. Середня товщина плаценти в цих жінок становила 2,7 $\pm 0,07$ см, а в решти жінок 1-ї та 2-ї групи та групи контролю $-3,9 \pm 0,08$ см і $3,71 \pm 0,04$ см відповідно $(\mathrm{p}<0,05)$. Така різниця в товщині плаценти свідчить про порушення іiі функції, оскільки гіпоплазія плаценти є прогностичною ознакою ПД.

На особливу увагу заслуговували 7 (12,9\%) вагітних, які народили дітей з ознаками перезрілості, тобто де можна думати про реальне ПВ. У цих жінок відбулись запізніли пологи в 42-43 тиж. гестації. Самостійно народили $5(71,4 \%)$ жінок, із них пологи були ускладнені у 3 $(42,8 \%)$ вагітних, а патологічні - у $2(28,6 \%)$. Оперативне розродження проведено у $2(28,6 \%)$ вагітних.

За даними ехографії, антенатально суттєвого збільшення БПР голівки плода не спостерігалось у 5 (71,4\%) жінок, ознаки плацентарної дисфункції (кальциноз, гіпоплазію та III ступінь зрілості) діагностувалися в 6 (85,7\%) вагітних, маловоддя та підвищена ехогенність АР - у 3 (42,8\%) обстежених, меконіальні води - у 3 (42,8\%) жінок.

Консервативно-очікувальна акушерська тактика 3 проведенням ультразвукового моніторингу стану плода та функціональної системи мати-плацента-плід після 41 тиж. гестації дала змогу завершити вагітність самостійними пологами у $74 \%$ жінок із переношуванням/пролонгуванням вагітності та у 83\% обстежених групи контролю.

Абдомінальне розродження проводилося в кожної третьої жінки з ПВ (30\%) та в кожної четвертої - 3 пролонгованою гестацією, ці показники майже вдвічі вищі, ніж у вагітних групи контролю (16,6\%). Слід зазначити, що кожна друга операція кесаревого розтину виконувалася за ургентними показаннями (гострий дистрес плода в пологах).

Перинатальних втрат не було. Переважна більшість новонароджених народилась із задовільною оцінкою за шкалою Апгар. Макросомія плода спостерігалась у 35\% новонароджених від жінок із ПВ, що майже вдвічі вище порівняно 3 немовлятами, народженими від жінок 2-ї групи та групи контролю.

\section{Висновки}

Таким чином, отримані результати ехографії свідчать про високий відсоток ПД у жінок із пролонгованою вагітністю та про розвиток морфофункціональних змін різного ступеня тяжкості у фетоплацентарному комплексі вже на 41-му тижні гестації, що, своєю чергою, відображається на компенсаторних можливостях плода та $є$ маркером можливих перинатальних ризиків у цих жінок.

Комплексний антенатальний ультразвуковий моніторинг стану плода та фетоплацентарного комплексу в жінок групи ризику щодо розвитку ПВ дає змогу вчасно виявити перинатальні проблеми та обрати адекватну тактику ведення вагітності й пологів.

\section{ЛIТЕРАТУРА}

1. Глуховец Б.И. Патология последа / Б.И. Глуховец, Н.Г. Глуховец. СПб., 2002. $-218 \mathrm{c}$.

2. Игнатко И.В. Профилактика плацентарной недостаточности у беременных группы высокого риска / И.В. Игнатко, М.В. Рыбин, В.Д. Дуболазов // Вопросы гинекологии, акушерства и перинатологии. - 2006. - Т. 5, № 1. - С. 11-20.

3. Милованов А.П. Корреляционные связи морфологических и функциональных показателей плаценты и новорожденного при нормальной доношенной, пролонгированной и истинно переношенной беременности / А.П. Милованов, М.В. Федорова // Архив патологии. - 2011. - № 3. - С. 50-53.

4. Милованов А.П. Патология системы мать-плацента-плод / А.П. Милованов. - М.: Медицина, 1999. - 447 с.

5. Омаров Н.С. Патогенез и дифференциальная диагностика переношенной и пролонгированной беременности / Н.С. Омаров, М.С. Асилятилова // Жур. Медицина. Наука и практика. - Махачкала. -2007 . - № 3. - С. 176-186.

6. П'ятикоп-Черняєва О.В. Патогенетичні механізми формування неврологічної перинатальної патології при переношуванні вагітності / О.В. П'ятикоп-Черняєва, В.В. Лазуренко, О.В. Мерцалова // Український вісник психоневрології. - 2010. - Т. 18, Вип. 4. - С. 31-33.

7. Переношенная беременность / А.Н. Стрижаков, И.В. Игнатко, Е.В. Тимохина, М.В. Рыбин. - М.: Изд. дом «Династия», 2006. - 145 с.

8. Резніченко Г.І. Переношена вагітність і запізнілі пологи / Г.І. Резніченко. - Запоріжжя: Паритет, 1998. - С. 180-181.

9. Сафонова І.М. Ультразвукова характеристика фетоплацентарного комплексу та особливостей біофізичного профілю плода та жінок із запальними захворюваннями нирок наприкінці III триместру вагітності / І.М. Сафонова, І.С. Лук`янова // Здоровье женщины. - 2009. № 1 (37). - С. 119-121.

10. Сидорова И.С. Фетоплацентарная недостаточность / И.С. Сидорова, И.О. Макаров. - М.: Знание, 2000. - С. 124-126.

11. Сичинова Л.Г. Течение беременности и родов при маловодии / Л.Г. Сичинова, Н.Б. Горюшина, В.А. Устинова // Акуш. гинекол. 2003. - № 2. - С. 25-28.

12. Торчинов А.М. Состояние фетоплацентарного комплекса по данным эхографии при применении препаратов кальция во время беременности / А.М. Торчинов, Г.Л. Доронин // Здоровье женщины. -2009 . - № 2(38). - С. 88.

13. Чернуха Е.А. Переношенная и пролонгированная беременность / Е.А.Чернуха. - М., 2007. - C. 17-19.

14. Grannum P. Placenta maturity staging in the prediction of fetal and neonatal outcomes / P. Grannum, P. Bernowitz, G. Hibbins // Amer. G. Obstet. Gynecol. - 1979. - Vol. 133, № 8. - P. 915-922.

15. Olesen A.W. Prenatal risk indicators of a prolonged pregnancy / A.W. Olesen, J.G. Westergaard // The Danish Birth Cohort 1998-2001 // Acta Obstet.Gynecol.Scand. - 2006. - Vol. 85 (11). - P. 41.

16. Yoder B.A. Changing obstetric practices associated with decreasing incidences of meconium aspiration syndrome / B.A. Yoder // J. Odstet. Gynecol. - 2002. - Vol. 99. - P. 431. 
Эхографические особенности фетоплацентарного комплекса женщин с переношенной и пролонгированной беременностью И.А. Жабченко, А.Е. Яремко, И.С. Лищенко, Е.Н. Дзюба, Т.Н. Коваленко

ГУ «Институт педиатрии, акушерства и гинекологии НАМН Украины», г. Киев, Украина

Цель - установить перинатальные риски у женщин с переношенной и пролонгированной беременностью по данным ультразвукового и допплеровского исследования плода и фетоплацентарного комплекса.

Пациенты и методы. Антенатально накануне родов проведено эхографическое исследование фетоплацентарного комплекса в 54 беременных с переношенной и пролонгированной беременностью и у 22 женщин с физиологической гестацией.

Результаты. Полученные результаты комплексного ультразвукового мониторинга состояния плода и фетоплацентарного комплекса накануне родов свидетельствуют, что признаки плацентарной дисфункции выявлены у 100\% беременных с переношенной беременностью и у $82 \%$ женщин с пролонгированной гестацией, что в три раза выше, чем у женщин с доношенной беременностью (31\%). Результаты исследования свидетельствуют о перинатальных рисках уже после 40 нед. гестации у женщин с пролонгированной беременностью.

Выводы. Консервативно-ожидательная тактика с проведением ультразвукового мониторинга состояния плода и фетоплацентарного комплекса при беременности сроком свыше 40-41 нед. позволила завершить беременность самостоятельными родами у 74\% обследованных с переношенной беременностью и пролонгированной гестацией и родить живых детей с удовлетворительной оценкой по шкале Апгар. Антенатальный эхографический мониторинг изменений в фетоплацентарном комплексе позволил выявить перинатальные риски у беременных с переношенной беременностью и выбрать адекватную тактику ведения беременности и родов.

Ключевые слова: эхография, переношенная, пролонгированная беременность, плацентарная диссункция, плод.

PERINATOLOGIYA I PEDIATRIYA.2015.2(62):25-28;doi10.15574/PP.2015.62.25

Echographic features fetoplacental complex of women with post-term pregnancy, and prolonged

I.A. Zhabchenko, A.E. Yaremko, I.S. Lischenko, E.N. Dziuba, T.N. Kovalenko

$\mathrm{SI}$ «Institute of pediatrics, obstetrics and gynecology NAMS of Ukraine», Kiev, Ukraine

Objective - to establish perinatal risk in women with post-term pregnancy, and prolonged by ultrasound and Doppler fetal and fetoplacental complex.

Patients and methods. Before delivery of antenatal echographic study conducted fetoplacental complex in 54 pregnant women with post-term and prolonged pregnancy and 22 women with physiological gestation.

Results. The results of complex ultrasonic monitoring fetal and fetoplacental complex before birth show that signs of placental dysfunction were found in $100 \%$ of pregnant women with post-term pregnancy, and $82 \%$ of women with prolonged gestation, which is three times higher than that of women with full-term pregnancy $(31 \%)$. The findings suggest that perinatal risk after 40 weeks. gestation in women with prolonged pregnancy.

Conclusions. Conservative - ozhidatelnaya tactics to conduct the ultrasound monitoring fetal and fetoplacental unit in pregnancy for a period of over $40-41$ weeks. will complete a pregnancy separate genera in $74 \%$ of patients with post-term pregnancy, and prolonged gestation and birth of children living with satisfactory Apgar scores. Antenatal echographic monitoring of changes in fetoplacental complex revealed perinatal risk in pregnant women with term pregnancy and choose the adequate tactics of pregnancy and childbirth.

Key words: ultrasound, post-term, prolonged pregnancy, placental dysfunction, fruit.

Сведения об авторах:

Жабченко И.А. - д.мед.н, зав. отделения патологии беременности и родов ГУ «ИПАГ НАМН Украины».

Адрес: г. Киев, ул. П. Майбороды, 8; тел. (044) 483-80-59.

Яремко Г.Е. - к.мед.Н., ст.н.сотр. отделения патологии беременности и родов ГУ «ИПАГ НАМН Украины».

Адрес: г. Киев, ул. П. Майбороды, 8; тел. (044) 483-80-59.

Лищенко И.С. - н.сотр. отделения патологии беременности и родов ГУ «ИПАГ НАМН Украины».

Адрес: г. Киев, ул. П. Майбороды, 8; тел. (044) 483-80-59.

Дзюба О.М. - к.мед.н., ст.н.сотр. отделения патологии беременности и родов ГУ «ИПАГ НАМН Украины».

Адрес: г. Киев, ул. П. Майбороды, 8; тел. (044) 483-80-59.

Коваленко Т.М. - к.н. физ.восп., ст.н.сотр. отделения патологии беременности и родов ГУ «ИПАГ НАМН Украины».

Адрес: г. Киев, ул. П. Майбороды, 8; тел. (044) 483-80-59.

Статья поступила в редакцию 1.04.2015 г. 


\title{
I.I. Редько \\ Клініко-імунологічні особливості перебігу внутрішньоутробних вірусних інфекцій у новонароджених
}

\author{
ДЗ «Запорізька медична академія післядипломної освіти МОЗ України», м. Запоріжжя, Україна
}

PERINATOLOGIYA I PEDIATRIYA.2015.2(62):29-31;doi10.15574/PP.2015.62.29

\begin{abstract}
Мета - вивчити клініко-імунологічні особливості перебігу внутрішньоутробних вірусних інфекцій у новонароджених.
Пацієнти та методи. Обстежено 834 матері та їхні хворі новонароджені 3 підозрою на внутрішньоутробну інфекцію. Основну групу склали 224 новонароджених з внутрішньоутробними вірусними інфекціями, контрольну - 30 здорових новонароджених. На підставі етіологічної верифікації визначено вірусологічні варіанти та основні клінічні форми внутрішньоутробних вірусних інфекцій, вивчено стан гуморальної та клітинної ланок імунітету, зміни інтерферонового статусу в гострий період інфекцій.

Результати. Встановлено, що при етіологічній верифікації внутрішньоутробних вірусних інсекцій переважали мікст-срорми. У гострий період внутрішньоутробних вірусних інсекцій відмічено зниження відносного вмісту СДЗ+, СД4+, СД19+, коефріцієнта супресії, функціональної активності нейтрофрілів, десріцит інтерферонового статусу при всіх клінічних формах мікст-фрорм внутрішньоутробних вірусних інфекцій.

Висновки. Зміни показників гуморальної та клітинної ланок імунітету, інтерфероновий статус залежать від клінічної та етіологічної фрорми інфекції. Найбільш тяжке ураження імунної системи спостерігається при мікст-вірусно-TORCH-інфеекціях.

Ключові слова: внутрішньоутробні вірусні інфекції, новонароджені, імунітет.
\end{abstract}

\section{Вступ}

$\mathbf{B}^{\text {Україні, незважаючи на досягнуті успіхи в удоско- }}$ $\mathbf{B}_{\text {наленні перинатальної допомоги вагітним і ново- }}$ народженим (НН), залишаються високими рівні перинатальної та неонатальної смертності, захворюваності НН, а серед причин захворюваності - значна питома вага внутрішньоутробних вірусних інфекцій (BВI) [1, 2, 3].

На сьогодні найбільш вивченими інфекціями у вагітних, плодів та НН є бактеріальні інфекції, вірусні інфекції групи TORCH та інфекції, що передаються статевим шляхом $[4,5,6]$. Питання про системне вивчення ВBI у НH залишаються відкритими, оскільки не до кінця вивчені. Бракує даних про поглиблене вивчення імунної відповіді у НH із різними клінічними варіантами перебігу ВВI, що обумовлює затримання специфічного лікування.

Mema роботи - вивчити клініко-імунологічні особливості перебігу ВВI у НH.

\section{Матеріали та методи дослідження}

Протягом раннього неонатального періоду проведено клініко-лабораторне обстеження 834 матерів та їхніх хворих НН із підозрою на ВВI.

Критеріями включення в обстеження були дані анамнезу: перенесена жінкою гостра респіраторна вірусна інфекція, реактивація TORCH-інфекцій під час даної вагітності; за даними ультразвукового обстеження - матково-плацентарна інфекція під час вагітності, передчасні пологи; з боку дитини: клінічні маркери - народжені 3 малою масою тіла (недоношені, внутрішньоутробна гіпотрофія, затримка внутрішньоутробного розвитку), респіраторний дистрес-синдром, вроджена пневмонія, клінічні прояви респіраторної інфекції у перші 3 доби життя (риніт, кон'юнктивіт, фарингіт, бронхіт), неврологічна симптоматика 3 народження, ранній жовтяничний синдром. Критеріями виключення з обстеження були: супутня тяжка патологія (вроджені або спадкові аномаліï), гестаційний вік менше 25 тижнів та більше 41 тижня.

Серед загальної кількості обстежених ВВІ верифіковані у 708 (84,9\%) хворих НН. Предметом поглибленого дослідження була група з 224 хворих НН із ВВI (31,6\%). Контрольну групу склали 30 здорових НН.

Застосовано загальноклінічні методи та спеціального дослідження. Клінічне спостереження включало визначення стану дитини при народженні, реєстрацію розладів ранньої неонатальної адаптації, аналіз факторів перина- тального ризику, виявлення ранніх специфічних і неспецифічних клінічних симптомів інфекцій.

Діагноз ВВI верифіковано на підставі клініко-анамнестичних даних і загальноприйнятих методів обстеження. Етіологічна верифікація ВВІ проведена в перші 3 доби життя при госпіталізації дитини в неонатологічне відділення пологових будинків або у відділення реанімації та в їхніх матерів після пологів. Специфічна діагностика вроджених грипу, парагрипу, аденовірусної та респіраторно-синцитіальної інфекцій проведена за допомогою методів прямої імунофлюоресценції, імунохроматографічного аналізу, серодіагностики (парні сироватки в реакції пасивної гемаглютинаціі) та на підставі результатів гістологічного та цитологічного дослідження послідів. Матеріалом для обстеження у дітей та матерів були змиви та зіскоби з носоглотки, кров із пуповинної та периферійної вен.

Специфічна діагностика вродженої ентеровірусної інфекції проведена за допомогою культурального методу 3 використанням курячих ембріонів та модифікованої реакції зв'язування комплементу із застосуванням політа моновалентних ентеровірусних діагностичних сироваток на імуноферментному аналізаторі. Матеріалом для обстеження в дітей та матерів були кров із пуповинної та периферійної вен, фекалії.

Специфічна діагностика інфекцій групи TORCH проведена методом імуноферментного аналізу та полімеразної ланцюгової реакції. Матеріалом для обстеження в дітей були кров, сеча, слина та ліквор, у матерів - кров.

Бактеріологічне обстеження НН та їхніх матерів проведено дворазово при надходженні дитини до відділення реанімації або до неонатального відділення пологового будинку та в динаміці перебування в стаціонарі. Матеріалом для бактеріологічного дослідження в дітей були фекалії, змиви з носоглотки, гній, кров, ліквор, у матерів змиви з носоглотки, виділення з піхви.

Оцінка імунного статусу включала дослідження вмісту сироваткових IgG, A, М у плазмі крові методом простої радіальної імунодифузії в агарі за Mancini G. et al. (1965), вміст фракцій лімфоцитів СД3+, СД4+, СД8+, СД16+, СД19+, СД25+ - методом моноклональних антитіл (ВМУ, Вітебськ, Білорусь); за допомогою тесту відтворення нітросинього тетразолію (НСТ-тест), визначення індексу завершеності фагоцитозу, фагоцитарного числа, індексу активації нейтрофілів. 
Кількісне визначення інтерферонів-альфа (IФН- $\alpha)$ та гама $(\gamma)$ проведено методом ІФА на фотометрі-аналізаторі SUNRISE (TECAN, Австрія) з використанням IФА тестсистем «Гамма-ІФН-ІФА» (ЗАО «Вектор-Бест», Росія).

Статистична обробка отриманих результатів здійснена з обчисленням параметричних і непараметричних критеріїв. Крім традиційного аналізу одномірних розподілів, проведено системний кореляційний аналіз. Статистичний аналіз здійснено з використанням пакету програм Statistiса 6.0 для персональних комп'ютерів.

\section{Результати дослідження та їх обговорення}

Проведене дослідження засвідчило, що серед загальної кількості обстежених НН із підозрою на вроджену інфекцію ВВІ виявилися у $224(31,6 \%)$. Серед них доношених було 132 (58,9\%), недоношених - 92 (41,1\%). Усі обстежені НН за станом здоров'я потребували лікування та догляду у відділеннях інтенсивної терапії та реанімації пологових будинків або в неонатологічних відділеннях дитячих лікарень.

Серед 224 дітей з ВВI спостерігалися: мікст-вірусні інфекції - у 77 (34,4\%), вірусно-бактеріальні інфекції у $62(27,7 \%), \quad$ мікст-вірусно-TORCH-інфекції у $53(23,6 \%)$, моновірусні інфекції - у 32 (14,3\%). У дітей з ВВI при верифікації етіологічного збудника вірус грипу А визначався у $15,6 \%$, парагрипу - у 20,5\%, аденовірус у $40,6 \%$, респіраторно-синцитіальний вірус у $27,2 \%$, ентеровіруси - у $48,2 \%$, цитомегаловірус у $56,5 \%$, вірус простого герпесу - у $22,6 \%$.

Чітке уявлення про клінічні варіанти перебігу BВI у НН дав аналіз результатів дослідження в групах хворих із моно- та мікст-формами інфекцій.

При моноінфекціях перебіг захворювання характеризувався середнім ступенем тяжкості у більшості випадків $(71,9 \%)$ у вигляді обструктивного бронхіту, ринофарингіту, кон'югаційної жовтяниці затяжного перебігу, гіпоксичної кардіоміопатії та виявлялася найменша чисельність недоношених дітей (6,2\%). Летального завершення захворювання не зареєстровано.

При мікст-вірусних інфекціях недоношені становили 45,5\%. У більшості (74,3\%) недоношених захворювання мало тяжкий перебіг із перших годин життя за рахунок респіраторного дистрес-синдрому, внутрішньоутробної пневмонії, гіпоксично-ішемічного та інфекційного ушкодження центральної нервової системи, ураження серцевосудинної системи: вроджені міокардити $(9,1 \%)$, гіпоксичні та інфекційні кардіоміопатії. У більшості доношених при мікст-вірусних інфекціях захворювання мало перебіг середнього ступеня тяжкості з ураженням дихальних шляхів (бронхіт, ринофарингіт) і тяжкий перебіг у 21,4\% - у вигляді вродженої вогнищевої пневмонії, інфекційної та гіпоксичної кардіоміопатії, гіпоксично-інфекційного ураження центральної нервової системи. Летальне завершення захворювання зареєстровано у 3,9\% недоношених дітей.

При мікст-вірусно-бактеріальних інфекціях визначалася найбільша питома вага недоношених $(51,6 \%)$ і переважно тяжкий перебіг захворювання у хворих НН. У недоношених захворювання мало тяжкий перебіг із перших годин життя за рахунок респіраторного дистрес-синдрому, вродженої пневмонії (68,7\%), інфекційного міокардиту $(25,0 \%)$ та інфекційно-гіпоксичного ушкодження центральної нервової системи- дифузний набряк головного мозку, внутрішньошлуночкові крововиливи II-III ступеня. При зазначеному варіанті перебігу BВI відмічався найвищий рівень летальності (11,3\%).
Характерним для перебігу мікст-вірусно-TORCHінфекцій було домінування уражень центральної нервової системи, у тому числі ізольованих церебральних форм (у 22,6\%), зумовлених цитомегаловірусом, вірусом простого герпесу і токсоплазмозом; гепатобіліарної системи у вигляді гепатиту (у 16,9\%) у сполученні з ураженням органів дихання. Летальність у даній групі становила $3,4 \%$ у недоношених дітей.

За даними результатів дослідження, у дітей з ВBI визначалися різного ступеня тяжкості варіанти ушкодження ланок гуморального та клітинного імунітету, зміни інтерферонового статусу.

При моноінфекціях відмічалися відхилення в показниках Т-клітинної ланки імунітету, але без статистично значущої різниці порівняно з контрольною групою, статистично значуще підвищення показників НСТ-тесту спонтанного $(27,6 \pm 11,4 \%$ проти $5,6 \pm 1,4 \%$ контрольної групи, $\mathrm{p}<0,05)$ на тлі зниження продукції ІФН- $\alpha(4,5 \pm 6,8$ пг/мл проти 4,88 $\pm 2,9$ пг/мл контрольної групи, $\mathrm{p}<0,05)$.

У дітей з мікст-вірусними інфекціями спостерігалося більш виражене ушкодження імунної системи зі статистично значущою різницею 3 контрольною групою зі зниженням відносного вмісту СД3+ $(55,6 \pm 5,5 \%$ проти $61,2 \pm 3,1 \%$ контрольної групи, $\mathrm{p}<0,05)$, СД $4+(37,3 \pm 5,8 \%$ проти $38,1 \pm 2,7 \%$ контрольної групи, $\mathrm{p}<0,05)$, коефіцієнта супресії $(1,42 \pm 0,4$ проти $2,0 \pm 0,2$ контрольної групи, $\mathrm{p}<0,05)$ на фоні збільшення відносної кількості клітин із маркерами активації СД16+ (22,3 $\pm 7,0 \%$ проти $17,1 \pm 1,9 \%$ контрольної групи, $\mathrm{p}<0,05)$, СД $25+(23,9 \pm 6,4 \%$ проти $19,3 \pm 2,2 \%$ контрольної групи, $\mathbf{p}<0,05)$, підвищення НСТ-тесту спонтанного (27,2 $211,3 \%$ проти $20,6 \pm 4,4 \%$ контрольної групи, $\mathbf{p}<0,05)$ та зниження НСТ-тесту стимульованого $(24,9 \pm 2,8 \%$ проти $33,8 \pm 7,0 \%$ контрольної групи, $\mathrm{p}<0,05)$ на тлі зниження рівня ІФН- $\alpha$ $(1,2 \pm 0,65$ пг/мл проти 4,88 22,9 пг/мл контрольної групи, $\mathrm{p}<0,05)$ та $\gamma(6,9 \pm 8,9$ пг/мл проти $7,1 \pm 3,0$ пг/мл контрольної групи, $\mathrm{p}<0,05)$.

У всіх дітей з вірусно-бактеріальними інфекціями мали місце значні зміни в імунній системі зі статистично значущим зниженням відносного вмісту СД $3+(54,8 \pm 5,5 \%$ проти $61,2 \pm 3,1 \%$ контрольної групи, $\mathrm{p}<0,05)$, СД $4+(35,0 \pm 3,7 \%$ проти $38,1 \pm 2,7 \%$ контрольної групи, $\mathbf{p}<0,05)$, СД19+ $(22,4 \pm 7,0 \%$ проти $24,3 \pm 4,4 \%$ контрольної групи, $\mathrm{p}<0,05)$ та коефіцієнта супресії $(1,4 \pm 0,2$ проти $2,0 \pm 0,2$ контрольної групи, $\mathrm{p}<0,05)$ на тлі активації маркерів клітинних реакцій: СД16+ (18,1 $\pm 9,6 \%$ проти $17,1 \pm 1,9 \%$ контрольної групи, $\mathrm{p}<0,05)$, СД25+ $(21,1 \pm 6,0 \%$ проти $19,3 \pm 2,2 \%$ контрольної групи, $\mathrm{p}<0,05)$ на тлі зниження продукції ІФН- $\alpha(2,3 \pm 4,3$ пг/мл проти 4,88 $\pm 2,9$ пг/мл контрольної групи, $\mathrm{p}<0,05)$. Найбільш виражені зміни імунного статусу мали діти з генералізованим перебігом захворювання.

У хворих із мікст-вірусно-TORCH-інфекціями спостерігалося найбільш тяжке ушкодження клітинної та гуморальної ланок імунітету зі зниженням відносної та абсолютної кількості СД3+ (53,8 $\pm 4,5 \%$ проти $61,2 \pm 3,1 \%$ контрольної групи, $\mathbf{p}<0,05)$, СД $4+(33,3 \pm 4,0 \%$ проти $38,1 \pm 2,7 \%$ контрольної групи, $\mathrm{p}<0,05)$, СД $19+(19,5 \pm 4,1 \%$ проти $24,3 \pm 4,4 \%$ контрольної групи, $<<0,05)$, коефіцієнта супресії $(1,47 \pm 0,2$ проти $2,0 \pm 0,2$ контрольної групи, $\mathrm{p}<0,05), \operatorname{IgG}(3,6 \pm 1,1$ г/л проти $6,6 \pm 0,8$ г/л контрольної групи, $\mathrm{p}<0,05), \operatorname{IgA}(0,02 \pm 0,17$ г/л проти $0,33 \pm 0,15$ г/л контрольної групи, $\mathrm{p}<0,05), \operatorname{IgM}(0,47 \pm 0,4$ г/л проти $0,42 \pm 0,2$ г/л контрольної групи, $\mathrm{p}<0,05)$ на тлі менш вираженої активації маркерів клітинних реакцій: СД16+ (17,4 $\pm 5,5 \%$ проти $17,1 \pm 1,9 \%$ контрольної групи, p<0,05), СД25+ (20,8 $\pm 11,8 \%$ проти $19,3 \pm 2,2 \%$ контрольної 
групи, $\mathrm{p}<0,05)$ та низький рівень IФН- $\alpha(1,23 \pm 2,1$ пг/мл проти $4,88 \pm 2,9$ пг/мл контрольної групи, $\mathbf{p}<0,05)$ та $\gamma(3,2 \pm 4,9$ пг/мл проти 7,1 $\pm 3,0$ пг/мл контрольної групи, $\mathrm{p}<0,05)$ зі статистично значущою різницею з показниками не тільки контрольної групи, але й з показниками ізольованих та інших мікст-вірусних інфекцій.

\section{Висновки}

При вірусологічній верифікації внутрішньоутробних вірусних інфекцій спостерігається перевага мікст-форм $(85,4 \%)$.

Клінічні форми вроджених вірусних інфекцій у новонароджених такі: генералізована $(4,5 \%)$, церебральна $(5,4 \%)$, вісцеральна $(74,0 \%)$, локалізована $(5,4 \%)$, субклінічна $(10,7 \%)$. Найбільш несприятливий перебіг захворювання відмічається при вірусно-бактеріальних інфекціях і мікст-вірусно-TORCH-інфекціях у недоношених.
Реакція імунної системи при вроджених вірусних інфекціях супроводжується змінами клітинної та гуморальної ланок імунітету. Спостерігається зниження відносного вмісту СД3+, СД4+, СД19+, коефіцієнта супресії, зниження функціональної активності нейтрофілів (ФЧН, НСТ-тесту стимульованого) та збільшення відносноі кількості клітин із маркерами активації (СД16+, СД25+). Найбільш тяжке ушкодження імунної системи відмічається при мікст-вірусно-ТORCH-інфекціях.

У гострий період BBI спостерігається дефіцит інтерферонового статусу. Ступінь вираженості цих змін залежить від клінічної форми інфекції. Зниження рівня ІФН- $\alpha$ відмічається при всіх клінічних формах інфекції. Найбільше зниження ІФН- $\alpha$ має місце при вірусноTORCH-інфекціях. Дефіцит IФН- $\gamma$ відзначається при вірусно-TORCH- та при мікст-вірусних інфекціях. Найбільше підвищення прозапальних цитокінів спостерігається при вірусно-бактеріальних інфекціях.

\section{ЛІТЕРАТУРА}

1. Внутриутробные инфекции: диагностика, лечение, профилактика / А.Л. Заплатников, Н.А. Коровина, М.Ю. Корнева, А.В. Чебуркин // Лечащий врач. - 2005. - № 8. - С. 45-49.

2. Екимова Е.В. Некоторые инфекции тORCH-комплекса (обзор литературы) / Е.В. Екимова, С.М. Муллабаева, М.Л. Алексеева // Проблемы репродукции. - 2007. - № 4. С. $12-20$.

3. Могилевкина И.А. Перинатальные инфекции (научно-доказательные подходы к оказанию помощи) / И.А. Могилевкина, Н.В. Гребельная, Н.Я. Жилка // Мистецтво лікування. - 2006. № 5-7. - C. $35-38$.
4. Особливості імунної відповіді у новонароджених з вродженою пневмонією / Т.К. Знаменська, О.І. Жданович, Т.М. Килимник, B.О. Счастлива // Неонатологія, хірургія та перинатальна медицина. 2012. - T. II, № 2 (4). - C. 18-22.

5. Особливості клініко-імунологічної адаптації новонароджених, матері яких інфіковані вірусом герпесу 2 типу / Т.К. Знаменська, О.А. Писарєв, О.А. Пояркова [та ін.] // Матеріали I з'їзду неонатологів України, м. Одеса, 24-25 жовтня 2007 р. - Одеса, 2007. - С. 46-47.

6. Tregoning J.S. Respiratory Viral Infections in Infants: Causes, Clinical Symptoms, Virology, and Immunology / J.S. Tregoning, J. Schwarze // Clin. Microbiol. Rev. - 2010. - Vol. 23, № 1. - P. 74-98.

\section{Клинико-иммунологические особенности течения внутриутробных вирусных инфекций у новорожденных И.и. Редько \\ ГЗ «Запорожская медицинская академия последипломного образования МЗ Украины», г. Запорожье, Украина \\ Цель - изучить клинико-иммунологические особенности течения внутриутробных вирусных инфекций у новорожденных. \\ Пациенты и методы. Обследованы 834 матери и их больные новорожденные с подозрением на внутриутробную инфекцию. Основную группу соста- вили 224 новорожденные с внутриутробными вирусными инсекциями, контрольную - 30 здоровых новорожденных. На основе этиологической верификации определены вирусологические варианты и основные клинические формы внутриутробных вирусных инфекций, изучено состояние гуморального и клеточного звеньев иммунитета, изменения интерферонового статуса в острый период инфекции. \\ Результаты. Установлено, что при этиологической верифрикации внутриутробных вирусных инсекций преобладали микст-формы. В острый период внутриутробных вирусных инфекций отмечено снижение относительного содержания СД3+, СД4+, СД19+, коэффициента супрессии, функциональ- ной активности нейтрофилов, дефицит интерферонового статуса при всех клинических формах инфекции.}

Выводы. Изменения показателей гуморального и клеточного звеньев иммунитета, интерферонового статуса зависят от клинической и этиологической форм инфекции. Наиболее тяжелое поражение иммунной системы наблюдается при микст-вирусно-TORCH-инфекциях.

Ключевые слова: внутриутробные вирусные инсекции, новорожденные, иммунитет.

PERINATOLOGIYA I PEDIATRIYA.2015.2(62):29-31;doi10.15574/PP.2015.62.29

Clinico-immunological characteristics of the course congenital viral infections in newborns

I.I. Redko

Zaporozhye Medical Academy of Postgraduate Education, Zaporozhye, Ukraine

Purpose. To study the clinico-immunological characteristics of the course congenital viral infections in newborns.

Patients and methods. Generally examined 834 woman and their sick newborns suspiciously on congenital viral infections. The main group consisted of 224 newborns with congenital viral infections, control group - 30 healthy newborns. On the base of etiological verification determine virological options and main clinical forms of congenital viral infections, the condition of humoral and cellular immunity, interferon status in acute period of infections is studied.

Results. Found, that at congenital viral infections predominate mixt-forms. In acute deseases we have established an reduction CD3+, CD4+, CD19+, suppression factor, functional activity neutrophils, deficit of interferon status at clinical forms of congenital viral infections in newborns.

Conclusion. Change the performance of humoral and cellular immunity, interferon status depend from clinical and etiological forms of intentions. The severe affection of immunity systems to detect of mixt-viral-TORCH-infections.

Key words: congenital viral infections, newborns, immunity.

Сведения об авторах:

Редько Ирина Ивановна - к.мед.н., доц. каф. педиатрии и неонатологии с курсом амбулаторной педиатрии ГЗ «ЗМАПО МЗ Украины». Адрес: г. Запорожье, ул. Комарова, 12; тел. (0612) 96-16-70.

Статья поступила в редакцию 20.03.2015 г. 


\title{
В.В. Подольський, А.Л. Каграманян, Вл.В. Подольський
}

\section{Клініко-епідеміологічна та соціологічна характеристика жінок фертильного віку з порушеннями репродуктивного здоров'я}

\author{
ДУ «Інститут педіатрії акушерства і гінекології НАМН України», м. Київ, Україна
}

PERINATOLOGIYA I PEDIATRIYA.2015.2(62):32-37;doi10.15574/PP.2015.62.32

Мета - визначити клініко-епідеміологічну та соціологічну характеристику жінок фертильного віку із порушеннями репродуктивного здоров'я. Пацієнти та методи. Створено спеціальну програму досліджень, розроблено і надруковано анкету «Вивчення стану репродуктивного здоров'я жінок фертильного віку - мешканок сільськогосподарського регіону України». За модель такого регіону обрано Бориспільський район Київської області. За допомогою анкетування виявлено 220 жінок із найбільш поширеними порушеннями репродуктивного здоров'я. 3 урахуваннях цих порушень були виокремлені три групи: I група - 80 (36,3\%) жінок із хронічними запальними захворюваннями статевих органів, II група - 70 (31,8\%) жінок із безпліддям, III група - 70 (31,8\%) жінок із порушенням менструального циклу.

Результати. Найбільш часті порушення спостерігалися в I групі, частота яких становила: хронічний вагініт — 26,25\%, хронічний сальпінгоофорит — $27,1 \%$, хронічний тазовий перитоніт - 15,7\%; безпліддя - 31,8\%. Найбільш часті причини, які призводили до безпліддя, такі: порушення овуляції — $52,5 \%$, трубно-перитонеальний фрактор - 15,2\%, чоловічий фрактор - 13,5\%.

Серед порушень репродуктивного здоров'я $(31,8 \%)$ у жінок найбільш часто виявлялись ациклічні маткові кровотечі - $34,3 \%$, менометрорагія — $33,75 \%$, гіперполіменорея - 23,75\%.

Висновки. Проведені дослідження дали змогу проаналізувати і виділити значущість медико-соціальних факторів у порушенні порушенні репродутивного здоров'я жінок, мешканок сільськогосподарського регіону України.

Ключові слова: клініко-епідеміологічні дослідження, жінки фертильного віку, хронічні запальні захворювання статевих органів, порушення менструального циклу, безпліддя.

\section{Вступ}

己е репродуктивне здоров'я (Р3). Показником нормального стану РЗ є адекватний рівень народжуваності та здоров'я майбутніх поколінь, що $з$ огляду на демографічну ситуацію, яка склалася, є проблемою національного значення для України $[4,6]$.

Здоров'я населення - показник добробуту держави, тому його збереження є завданням державного рівня.

Збереження P3 жінки тісно пов'язане 3 якістю iï життя, є актуальною медичною та соціальною проблемою внаслідок його вирішального впливу на здоров'я нації в цілому та необхідністю виправлення загрозливої демографічної ситуації в Україні. Водночас в Україні останніми роками спостерігається складна соціальноекономічна ситуація. У скрутному становищі перебуває система охорони здоров'я, насамперед у сільських регіонах $[1,2]$.

В Україні, де зростає безробіття, поширюється бідність народу, загострюються екологічні проблеми, посилюється соціальна напруга та політична нестабільність, склалась тяжка ситуація щодо здоров'я жінок і дітей. Масштаби втрат здоров'я жінок значні і протягом останніх років продовжують зростати [8]. Це підтверджують поодинокі клініко-епідеміологічні дослідження стану РЗ жінок фертильного віку (ЖФВ) у взаємозв'язку з вивченням їх соціального, екологічного, побутового середовища, проведені в нашій країні, зокрема, в ДУ «ППАГ НАМН України» $[3,5,7]$.

Клініко-епідеміологічні дослідження стану здоров'я, у тому числі репродуктивного, проведені серед мешканок типового сільськогосподарського регіону. Попередні дослідження показали, що зайнятість жінок у сільському господарстві України, незважаючи на соціальні та економічні зміни, залишається високою. У зв'язку з цим з'явилася необхідність оцінити умови життя і праці жінок та вивчити фактори ризику, які можуть впливати на стан їхнього здоров'я, зокрема репродуктивного, з метою розробки ефективних профілактичних заходів [5, 7].

Багатофакторний підхід до вивчення здоров'я й патології населення, у тому числі окремих професійних груп, може бути реалізований на основі проведення епідеміологічних досліджень. При цьому доцільно весь комплекс досліджень здійснювати на тих самих територіях для того, щоб простежити можливу динаміку як якості навколишнього середовища, так і динаміку досліджуваної патології. Це дасть змогу визначити питоме значення кожного фактора в розвитку загальної репродуктивної патології жіночих контингентів обстежуваних територій і обгрунтувати відповідні профілактичні заходи [3].

Mema роботи - визначити клініко-епідеміологічну та соціологічну характеристику ЖФВ із порушеннями РЗ.

\section{Матеріали та методи дослідження}

Перед клініко-епідеміологічними дослідженнями здійснено значний підготовчий етап, протягом якого створено спеціальну програму досліджень, розроблено і надруковано анкету «Вивчення стану репродуктивного здоров'я жінок фертильного віку - мешканок сільськогосподарського регіону України». За модель такого регіону обрано Бориспільський район Київської області.

Анкета представлена у вигляді надрукованої в друкарні брошури обсягом 127 сторінки, включає понад 700 параметрів, які характеризують стан соматичного здоров'я, особливості РЗ ЖФВ і фактори ризику. Побудова запитника і склад питань розроблені так, що на них може дати відповідь жінка з будь-яким рівнем освіти і соціального стану. Окремі розділи анкети присвячені лікарському інтерв'ю і результатам загальноклінічних і спеціальних досліджень жінок.

Анкети роздавались ЖФВ для заповнення, після чого дослідниками вносилась в анкети інформація з медичної документації з лікувальної установи (у разі, якщо жінка зверталась по медичну допомогу) та після цього жінки запрошувались на бесіду і огляд лікаря-гінеколога. Далі заповнені анкети оброблялися, а інформація вводилася в пам'ять комп'ютера за допомогою спеціальної програми MSACCESS.

\section{Результати дослідження та їх обговорення}

Результати досліджень показали, що в популяції ЖФВ, мешканок сільськогосподарського регіону Украї- 
Розподіл обстежених жінок фертильного віку, мешканок сільськогосподарського регіону, за віком, абс. (\%)

\begin{tabular}{|c|c|c|c|}
\hline \multirow{2}{*}{ Вік (роки) } & \multicolumn{3}{|c|}{ Група жінок фертильного віку } \\
\cline { 2 - 4 } & $\mathbf{I}(\mathbf{n}=\mathbf{8 0})$ & $\mathbf{I I}(\mathbf{n}=\mathbf{7 0})$ & III $(\mathbf{n}=\mathbf{7 0})$ \\
\hline $15-19$ & $22(27,8)$ & $1(1,43)$ & $25(27,1)$ \\
\hline $20-25$ & $20(25,0)$ & $14(20,0)$ & $9(12,7)$ \\
\hline $26-30$ & $21(26,25)$ & $26(37,1)$ & $5(7,1)$ \\
\hline $31-35$ & $7(8,75)$ & $21(30,0)$ & $6(8,5)$ \\
\hline $36-40$ & $5(6,25)$ & $7(10,0)$ & $4(5,7)$ \\
\hline $41-45$ & $4(5,0)$ & $1(1,43)$ & $2(2,8)$ \\
\hline $46-49$ & $1(1,25)$ & - & \\
\hline
\end{tabular}

Розподіл жінок фертильного віку, мешканок сільськогосподарського регіону, за сімейним станом, абс. (\%)

\begin{tabular}{|l|c|c|c|}
\hline \multicolumn{1}{|c|}{ Сімейний стан } & \multicolumn{2}{|c|}{ Група жінок фертильного віку } \\
\cline { 2 - 4 } & $\mathbf{I ~ ( n = 8 0 )}$ & II (n=70) & III (n=70) \\
\hline Благополучна родина & $25(31,25)$ & $37(51,4)$ & $18(25,7)$ \\
\hline Неблагополучна родина & $27(33,75)$ & $11(15,7)$ & $13(18,5)$ \\
\hline Неповна сім'я & $25(31,25)$ & $5(7,1)$ & $13(18,5)$ \\
\hline Батьки, які були судимі & $3(3,75)$ & $7(10,0)$ \\
\hline
\end{tabular}

ни, виявлено 220 жінок із найбільш поширеними порушеннями РЗ, які були у вигляді хронічних запальних захворювань статевих органів (ХЗЗСО), безпліддя та порушення менструального циклу (ПМЦ). Це дало змогу розподілити ЖФВ із порушенням РЗ на три групи: I група становила 80 (36,3\%) жінок із ХЗЗСО, II група - 70 (31,8\%) жінок із безпліддям, III група - 70 (31,8\%) жінок із ПМЦ.

Для порівняння слід зазначити, що аналогічні порушення Р3 у жінок, мешканок промислового регіону України, становили: ХЗЗСО - 82\%, безпліддя - 27\%, ПМЦ - 36\%.

При дослідженні виявлено, що в жінок із ХЗЗСО середній вік становив $15-19$ років - $22(27,8 \%)$, у жінок із безпліддям він складав 26-30 років - 26 (37,1\%), а в жінок із ПМЦ він дорівнював 20-25 років 25 (35,7\%), (табл. 1).

За сімейним станом серед обстежених жінок ми отримали показники, наведені в таблиці 2.

3 наведеної таблиці 2 видно, що в I групі зустрічались жінки 3 неблагополучної родини - 27 (33,75\%), у II та III групах було відповідно 36 (51,4\%) і 37 (52,8\%) жінок з благополучної родини.

За рівнем освіти групи жінок розподілились таким чином: серед жінок I групи мали вищу освіту 9 (11,25\%) осіб, незакінчену вищу освіту - 16 (20,0\%), професійнотехнічну -36 (45,0\%), середню - 16 (20,0\%), середню незакінчену -3 (3,75\%). Жінки II групи переважно мали професійно-технічну освіту -37 (52,8\%), а також були з вищою та середньою освітою - відповідно 11 (15,7\%) i $11(15,7 \%)$. Жінки III групи переважно мали професійнотехнічну освіту - $44(62,8 \%)$ і незакінчену середню освіту $1(1,43)$, (табл. 3$)$.

За соціальним станом обстежених жінок дані відображені в таблиці 4.

3 наведених даних таблиці 4 видно, що за соціальним станом у I групі переважали жінки-робітниці $21(26,25 \%)$, службовці - 19 (23,75\%), безробітні $14(17,5 \%)$, домогосподарки - 15 (18,75\%), студентки - 11 (13,75\%). У II групі переважали також жінки-робітниці $23(32,9 \%)$ і домогосподарки - 18 (25,7\%), службовці - 16 (22,8\%), безробітні - 13 (18,6\%), найменше було студентів 7 (10,0\%). Серед жінок III групи більшість жінок були службовцями - 23 (32,8\%) та робітницями - 18 (25,7\%).

При аналізі даних щодо соматичної захворюваності в обстежених жінок I та II груп передусім звертає на себе увагу висока кількість алергічних проявів - 27 (33,75\%), захворювань органів травлення - 19 (23,75\%), захворювань нирок - 11 (13,75\%). У жінок III групи найчастіше спостерігалися захворювання крові - $18(25,7 \%)$, органів травлення - 16 (22,8\%) та алергічні прояви - 15 (21,4\%), (табл. 5).

В усіх трьох групах найнижчим показником соматичної захворюваності був цукровий діабет (відповідно I група $-1(1,25 \%)$, II група $-3(4,3 \%)$, III група $3(4,3 \%))$ і захворювання серцево-судинної системи (відповідно 4 (5,0\%), 2 (2,8\%) та 5 (7,1\%)).

Таблиия 3

Розподіл жінок фертильного віку, мешканок сільськогосподарського регіону, за освітою, абс. (\%)

\begin{tabular}{|l|c|c|c|c|c|}
\hline \multirow{2}{*}{ Група } & \multicolumn{4}{|c|}{ Кількість жінок фертильного віку за рівнем освіти } \\
\cline { 2 - 6 } & вища & незакінчена вища & $\begin{array}{c}\text { професійно- } \\
\text { технічна }\end{array}$ & середня & незакінчена середня \\
\hline I $(\mathrm{n}=80)$ & $9(11,25)$ & $16(20,0)$ & $36(45,0)$ & $16(20,0)$ & $3(3,75)$ \\
\hline II $(\mathrm{n}=70)$ & $11(15,7)$ & $7(10,0)$ & $37(52,8)$ & $11(15,7)$ & $4(5,7)$ \\
\hline II $(\mathrm{n}=70)$ & $10(14,3)$ & $6(8,5)$ & $44(62,8)$ & $9(12,8)$ & $1(1,43)$ \\
\hline
\end{tabular}

Таблиия 4

Розподіл жінок фертильного віку, мешканок сільськогосподарського регіону, за соціальним станом, абс. (\%)

\begin{tabular}{|c|c|c|c|c|c|}
\hline \multirow{2}{*}{ Група } & \multicolumn{5}{|c|}{ Кількість жінок фертильного віку за соціальним станом } \\
\cline { 2 - 6 } & студентки & службовці & робітниці & домогосподарки & безробітні \\
\hline $\mathrm{I}(\mathrm{n}=80)$ & $11(13,75)$ & $19(23,75)$ & $21(26,25)$ & $15(18,75)$ & $14(17,5)$ \\
\hline $\mathrm{II}(\mathrm{n}=70)$ & $7(10,0)$ & $16(22,8)$ & $23(32,9)$ & $18(25,7)$ & $13(18,6)$ \\
\hline $\mathrm{III}(\mathrm{n}=70)$ & $14(20,0)$ & $23(32,8)$ & $18(25,7)$ & $8(11,5)$ & $7(10,0)$ \\
\hline
\end{tabular}


Таблиия 5

Соматична захворюваність у жінок фертильного віку, мешканок сільськогосподарського регіону, абс. (\%)

\begin{tabular}{|c|c|c|c|}
\hline \multirow{2}{*}{ Форма захворювання } & \multicolumn{3}{|c|}{ Група жінок фертильного віку } \\
\hline & $I(n=80)$ & II $(n=70)$ & III $(n=70)$ \\
\hline Серцево-судинної системи & $4(5,0)$ & $2(2,8)$ & $5(7,1)$ \\
\hline Органів травлення & $19(23,75)$ & $14(20,0)$ & $16(22,8)$ \\
\hline Нирок & $11(13,75)$ & $16(22,8)$ & $6(8,5)$ \\
\hline Алергічні прояви & $27(33,75)$ & $23(328)$ & $15(21,4)$ \\
\hline Цукровий діабет & $1(1,25)$ & $3(4,3)$ & $3(4,3)$ \\
\hline Органів дихання & $7(8,25)$ & $4(5,7)$ & $7(10,0)$ \\
\hline Крові & $11(13,75)$ & $8(11,4)$ & $18(25,7)$ \\
\hline
\end{tabular}

Характер менструальної функції в жінок фертильного віку,

Таблиия 6 мешканок сільськогосподарського регіону, абс. (\%)

\begin{tabular}{|c|c|c|c|}
\hline \multirow{2}{*}{ Менструальна функція } & \multicolumn{3}{|c|}{ Група жінок фертильного віку } \\
\hline & $I(n=80)$ & II $(n=70)$ & III $(n=70)$ \\
\hline Менархе до 15 років & $69(86,25)$ & $62(88,5)$ & $63(90,0)$ \\
\hline Менархе від 15 років & $11(13,75)$ & $8(11,4)$ & $7(10,0)$ \\
\hline Цикл 21-25 днів & $15(18,75)$ & $11(15,7)$ & $14(20,0)$ \\
\hline 26-28 днів & $42(52,5)$ & $39(55,7)$ & $43(61,4)$ \\
\hline 29-35 днів & $43(53,75)$ & $20(2,8)$ & $13(18,5)$ \\
\hline Нерегулярні менструації & $43(53,75)$ & $51(72,8)$ & $65(92,8)$ \\
\hline Крововтрата мізерна & $27(33,75)$ & $23(32,8)$ & $26(51,4)$ \\
\hline Крововтрата помірна & $49(61,25)$ & $33(47,1)$ & $35(50,0)$ \\
\hline Крововтрата значна & $4(5,0)$ & $14(20,0)$ & $9(12,8)$ \\
\hline Біль виражений & $58(72,5)$ & $47(67,1)$ & $36(51,4)$ \\
\hline
\end{tabular}

Підвищений рівень соматичної захворюваності в жінок цих груп не тільки впливає на стан РЗ до настання вагітності, але і може стати негативним фоном, який приводить до розвитку ускладнень вагітності і пологів, а в деяких випадках впливає на патологічний післяпологовий період.

Аналізуючи дані щодо соматичного анамнезу ЖФВ, мешканок сільськогосподарського регіону, виявлено, що всі жінки в дитинстві розвивалися нормально: вік менархе становив у середньому $12,4 \pm 4,1$ року і в усіх обстежених жінок був до 15 років включно (табл. 6).

Особлива увага при обстежені жінок приділялася характеру менструальної функції та клінічному перебігу менструації. Група жінок із ХЗЗСО мала такі показники: нормальне менархе - 69 (86,25\%), пізнє менархе - 11 (13,75\%), нерегулярний МЦ - у 43 (53,75\%); за характером крововтрати: крововтрата мізерна - 27 (33,75\%), крововтрата помірна 49 (61,25\%), крововтрата значна - 4 (5,0\%); тривалість МЦ цикл 21-25 днів - 15 (18,75\%); цикл 26-28 днів 42 (52,5\%); м29-35 днів - у 43 (53,75\%), виражений біль супроводжувались у 58 (72,5\%) випадках.

Група жінок із безпліддям мала такі показники: нормальне менархе - 62 (88,5\%), пізнє менархе - 8 (11,4\%), нерегулярний МЦ - у 51 (72,8\%); за характером крововтрати: крововтрата мізерна - 23 (32,8\%), крововтрата помірна - 33 (47,1\%), крововтрата значна - $14(20,0 \%)$, тривалість МЦ: $21-25$ днів - 14 (20,0\%), цикл 26-28 днів $39(55,7 \%)$, цикл $29-35$ днів - 20 (2,8\%), виражений біль у $47(67,1 \%)$ випадків (табл. 6$)$
У жінок із ПМЦ нормальне менархе зустрічалось у $63(90,0 \%)$, пізнє - в 7 (10,0\%), тривалість МЦ 25-28 днів зустрічалась у $43(61,4 \%)$, нерегулярний МЦ у $65(92,8 \%)$, виражений біль - у $36(51,4 \%)$.

Протягом життя гінекологічні оперативні втручання були в анамнезі в I групі у $64(80,0 \%)$ жінок, у II групі у $53(75,7 \%)$, у III групі - у $56(80,0 \%)$, із них відповідно: операції при доброякісних кістах яєчників у $13(16,25 \%)$, у $16(22,8 \%)$ і в $19(27,1 \%)$, з приводу позаматкової вагітності - у 7 (8,75\%), у 4 (5,7\%) і у $3(4,3 \%)$, апоплексія яєчників - у $3(3,75 \%)$, в $1(1,4 \%)$ і в $1(1,4 \%)$, 3 приводу ерозії шийки матки в I групі - у 41 (51,25\%), у II групі - у 32 (45,7\%), у III групі - у 33 (47,1\%). Xiрургічні операції становили: видалення апендиксу в I групі $16(20,0 \%)$, у II групі - $17(24,3 \%)$, у III групі $14(20,0 \%)$, (табл. 7$)$.

у всіх обстежених жінок вивчалися показники загального та спеціального (акушерсько-гінекологічного) анамнезу, проводились загально-клінічні аналізи та гінекологічні обстеження стану органів репродуктивної системи. Результати досліджень дали змогу встановити особливості гінекологічної захворюваності і стану Р3 обстежених жінок (табл. 8 і 9).

Найбільшу групу становили жінки з ерозією шийки матки, які розподілилися між групами таким чином: серед жінок I групи - 51,25\%, серед жінок II групи - 31,4\%, серед жінок III групи - 32,8\%. Другим за значенням параметром, що характеризує ПРЗ обстежених жінок, були

Перенесені гінекологічні та хірургічні операції в анамнезі в жінок фертильного віку,

Таблиия 7 мешканок сільськогосподарського регіону, абс. (\%)

\begin{tabular}{|c|c|c|c|c|c|}
\hline $\begin{array}{c}\text { Група жінок } \\
\text { фертильного віку }\end{array}$ & $\begin{array}{c}\text { Апоплексія } \\
\text { яєчника }\end{array}$ & $\begin{array}{c}\text { Доброякісна } \\
\text { кіста } \\
\text { яєчників }\end{array}$ & $\begin{array}{c}\text { Операція 3 приводу } \\
\text { позаматкової } \\
\text { вагітності }\end{array}$ & $\begin{array}{c}\text { Апен- } \\
\text { дектомії }\end{array}$ & $\begin{array}{c}\text { 3 приводу ерозії } \\
\text { шийки матки }\end{array}$ \\
\hline $\mathrm{I}(\mathrm{n}=80)$ & $3(3,75)$ & $13(16,25)$ & $7(8,75)$ & $16(20,0)$ \\
\hline$I I(n=70)$ & $1(1,4)$ & $16(22,8)$ & $4(5,7)$ & $17(24,3)$ & $32(51,25)$ \\
\hline$I I I(n=70)$ & $1(1,4)$ & $19(27,1)$ & $3(4,3)$ & $14(20,0)$ \\
\hline
\end{tabular}


Гінекологічна захворюваність у жінок фертильного віку,

мешканок сільськогосподарського регіону, абс. (\%)

\begin{tabular}{|c|c|c|c|}
\hline \multirow{2}{*}{ Гінекологічна патологія } & \multicolumn{3}{|c|}{ Група жінок фертильного віку } \\
\hline & $I(n=80)$ & II $(n=70)$ & III $(n=70)$ \\
\hline Ерозія шийки матки & $41(51,25)$ & $22(31,4)$ & $23(32,8)$ \\
\hline Лейоміома матки & $2(2,5)$ & $3(4,3)$ & $1(1,4)$ \\
\hline Гіперпластичні процеси ендометрію & $8(8,0)$ & $5(7,1)$ & $6(8,5)$ \\
\hline Кісти яєчників & $13(16,25)$ & $16(22,8)$ & $19(27,1)$ \\
\hline Генітальний ендометріоз & $4(5,0)$ & $4(5,7)$ & $2(2,8)$ \\
\hline Синдром полікістозних яєчників & $2(2,5)$ & $10(14,2)$ & $6(8,5)$ \\
\hline Передменструальний синдром & $3(3,75)$ & - & $3(4,3)$ \\
\hline Штучні аборти & $7(8,75)$ & $8(11,4)$ & $10(14,2)$ \\
\hline Аномалії розвитку статевих органів & - & 2 & - \\
\hline
\end{tabular}

Стан репродуктивного здоров'я в жінок фертильного віку,

мешканок сільськогосподарського регіону, абс. (\%)

\begin{tabular}{|c|c|c|c|}
\hline \multirow{2}{*}{ Гінекологічна патологія } & \multicolumn{3}{|c|}{ Група жінок фертильного віку } \\
\hline & $I(n=80)$ & II (n=70) & III ( $(n=70)$ \\
\hline Невиношування вагітності & $17(21,25)$ & $8(11,4)$ & $7(10,0)$ \\
\hline Штучні аборти & $7(8,75)$ & $8(11,4)$ & $10(14,2)$ \\
\hline Перинатальна смертність & $3(3,75)$ & $1(1,4)$ & $1(1,4)$ \\
\hline Материнська смертність & - & - & - \\
\hline Онкологічні та передракові захворювання & $13(16,25)$ & $3(4,3)$ & $7(10,0)$ \\
\hline Соматична захворюваність & $14(17,5)$ & $13(18,5)$ & $10(14,2)$ \\
\hline Захворювання, перенесені в дитинстві & $20(25,0)$ & $26(37,1)$ & $23(32,8)$ \\
\hline Венеричні захворювання & $6(7,5)$ & $11(15,7)$ & $12(17,1)$ \\
\hline
\end{tabular}

Таблиия 10

Частота різних форм хронічних запальних захворювань статевих органів у жінок фертильного віку, мешканок сільськогосподарського регіону, абс. (\%)

\begin{tabular}{|c|c|c|c|}
\hline \multirow{2}{*}{ Гінекологічна патологія } & \multicolumn{3}{|c|}{ Група жінок фертильного віку } \\
\hline & $I(n=80)$ & II $(\mathbf{n = 7 0 )}$ & III $(n=70)$ \\
\hline Хронічний вульвіт & $17(21,25)$ & $12(17,1)$ & $10(14,3)$ \\
\hline Хронічний вагініт & $21(26,25)$ & $16(22,9)$ & $12(18,1)$ \\
\hline Хронічний цервіцит & $14(17,5)$ & $7(10,0)$ & $19(27,1)$ \\
\hline Хронічна запальна хвороба матки & $7(8,75)$ & $5(7,1)$ & $12(17,1)$ \\
\hline Хронічний сальпінгоофорит & $14(17,5)$ & $19(27,1)$ & $13(18,5)$ \\
\hline Хронічний тазовий перитоніт & $7(8,75)$ & $11(15,7)$ & $4(5,7)$ \\
\hline
\end{tabular}

кісти яєчників (відповідно по групах - 16,25\%, 22,8\% i $27,1 \%)$.

3 наведених у таблиці 9 даних видно, що у ЖФВ, мешканок сільськогосподарського регіону, спостерігалися різні ПРЗ.

Інші нозологічні одиниці розподілилися таким чином: захворювання, перенесені в дитинстві, в I групі спостерігалися у $20(25,0 \%)$ жінок, у II групі - у $26(37,1 \%)$, у III групі - у $23(32,8 \%)$; невиношування вагітності відповідно в $17(21,25 \%), 8(11,4 \%)$ і $7(10,0 \%)$, соматична захворюваність - відповідно в 14 (17,5\%), 13 (18,5\%) і $10(14,2 \%)$, онкологічні та передракові захворювання відповідно в $13(16,25 \%), 3$ (4,3\%) і 7 (10,0\%), штучні аборти - відповідно в 7 (8,75\%), 8 (11,4\%) і 10 (14,2\%), венеричні захворювання - відповідно в 6 (7,5\%), $11(15,7 \%)$ і $12(17,1 \%)$ жінок.

Ці дані переконливо вказали на незадовільний стан Р3 у ЖФВ, мешканок сільськогосподарського регіону.

Частота різних форм ХЗЗСО у ЖФВ, мешканок сільськогосподарського регіону, наведена в таблиці 10.

Характерними клінічними симптомами при ураженні нижніх відділів урогенітальних органів у жінок I групи з ХЗЗСО були свербіж, виділення, печія, дизуричні симптоми - відповідно 21,25\%, 26,25\% і 17,5\%, у II групі відповідно 17,1\%, 22,9\% і 10,0\%, у ІІІ групі - відповідно $14,3 \%, 18,1 \%$ i $27,1 \%$.

Таблиия 11

Порушення менструального циклу в жінок фертильного віку, мешканок сільськогосподарського регіону, абс. (\%)

\begin{tabular}{|c|c|c|c|}
\hline \multirow{2}{*}{$\begin{array}{c}\text { Характер порушення } \\
\text { менструального циклу }\end{array}$} & \multicolumn{3}{|c|}{ Група жінок фертильного віку } \\
\hline & I (n=80) & II $(n=70)$ & III $(\mathbf{n = 7 0 )}$ \\
\hline Менометрорагія & $27(33,75)$ & $9(12,8)$ & $11(15,7)$ \\
\hline Гіперменорея & $19(23,75)$ & $17(24,3)$ & $16(22,9)$ \\
\hline Ациклічні маткові кровотечі & $18(22,5)$ & $13(18,5)$ & $24(34,3)$ \\
\hline \multicolumn{4}{|l|}{ Аменорея: } \\
\hline - первинна & $1(1,25)$ & $8(11,4)$ & $1(1,4)$ \\
\hline - вторинна & $7(8,75)$ & $14(20,0)$ & $10(14,3)$ \\
\hline \multicolumn{4}{|l|}{ Олігоменорея: } \\
\hline - первинна & $5(6,25)$ & $8(11,4)$ & $6(8,5)$ \\
\hline - вторинна & $3(3,75)$ & $1(1,4)$ & $2(2,8)$ \\
\hline
\end{tabular}


Таблиия 12

Структура безплідності в жінок фертильного віку, мешканок сільськогосподарського регіону, абс. (\%)

\begin{tabular}{|l|c|c|}
\hline \multicolumn{1}{|c|}{ Структура безплідності } & Первинна безплідність (n=59) & Вторинна безплідність (n=11) \\
\hline Порушення овуляції & $31(52,5)$ & $4(36,7)$ \\
\hline Трубний генез & $9(15,2)$ & $2(18,2)$ \\
\hline Матковий генез & $2(3,4)$ & $1(9,1)$ \\
\hline Шийковий генез & - & - \\
\hline Імунологічний генез & $1(0,7)$ & - \\
\hline Урогенітальна інфекція & $3(5,1)$ & $2(18,2)$ \\
\hline Ендометріоз & $4(6,7)$ & $1(9,1)$ \\
\hline Міома матки & $1(0,7)$ & $1(9,1)$ \\
\hline Чоловічий фактор & $8(13,5)$ & - \\
\hline
\end{tabular}

При захворюваннях верхнього відділу найчастішими клінічними ознаками були періодичний біль унизу живота: у I групі - $14(17,5 \%)$, у II групі - $19(27,1 \%)$, у III групі - $13(18,5 \%)$.

Ураження урогенітальних органів із поєднанням нижнього і верхнього рівнів у жінок I групи виявлено у $35(43,75 \%)$, II групи - у 35 (50,0\%), III групи - у 31 (44,3\%) випадку.

Дані щодо ПМЦ наведено в таблиці 11.

Порушення менструального циклу за характером були такі. У I групі жінок менометрорагія спостерігалася у 27 (33,75\%) жінок, гіперменорея - у 19 (23,75\%), ациклічні маткові кровотечі - у 18 (22,5\%), аменорея первинна - в $1(1,25 \%)$, аменорея вторинна - у 7 (8,75\%), олігоменорея первинна - у 5 (6,25\%), вторинна - у $3(3,75 \%)$ У II групі гіперменорея відмічалася у 17 (24,3\%) жінок, аменорея вторинна - у 14 (20,0\%), ациклічні маткові кровотечі - у 14 (20,0\%), менометрорагія - у $9(12,8 \%)$, олігоменорея первинна - у 8 (11,4\%). У III групі переважна кількість жінок були з ациклічними матковими кровотечами - 24 (34,3\%), гіперменорея зустрічалась у $16(22,9 \%)$, менометрорагія - в $11(15,7 \%)$, аменорея у $22(31,4 \%)$, олігоменорея - в $11(15,7 \%)$ випадках.

Структура безплідності у ЖФВ, мешканок сільськогосподарського регіону, наведена в таблиці 12.

У групі жінок із первинною безплідністю переважали такі види ускладнень: порушення овуляції - у 31 (52,5\%), безплідність трубного генезу - у 9 (15,2\%), чоловічий фактор - у 9 (15,2\%), ендометріоз - у 4 (6,7\%).

При вторинній безплідності на першому місці були порушення овуляції - 4 (36,7\%), урогенітальні інфекції -
2 (18,2\%). Безплідність трубного генезу зустрічалась у $2(18,2 \%)$ жінок.

Таким чином, у результаті комплексного дослідження стану репродуктивної системи, проведеного серед ЖФВ, мешканок сільськогосподарського регіону, виявлено, що найчастіше зустрічаються ХЗЗСО, безпліддя, як первинне, так і вторинне і ПМЦ. Виявлені порушення потребують подальшого дослідження для визначення оптимальних шляхів їх профілактики і лікування.

\section{Висновки}

Проведені дослідження дали змогу надати клініко-епідеміологічну та соціологічну характеристику ЖФВ, мешканок сільськогосподарського регіону України, та з'ясувати в них найбільш часті порушення РЗ.

Найчастіші порушення Р3 спостерігалися в групі з ХЗЗСО (36,3\%), частота яких становила: хронічний вагініт - $26,25 \%$, хронічний сальпінгоофорит $-27,1 \%$, хронічний тазовий перитоніт - 15,7\%; безпліддя $-31,8 \%$. Найбільш часті причини, які призводили до безпліддя, такі: порушення овуляції - 52,5\%, трубно-перитонеальний фактор - 15,2\%, чоловічий фактор - 13,5\%.

Серед ПМЦ $(31,8 \%)$ у ЖФВ найбільш часто виявлялись ациклічні маткові кровотечі - 34,3\%, менометрорагія $-33,75 \%$, гіперполіменорея $-23,75 \%$.

Проведені дослідження дали змогу проаналізувати i виділити значущість медико-соціальних факторів у порушенні РЗ ЖФВ, мешканок сільськогосподарського регіону України, що сприятиме в подальшому розробці системи заходів для профілактики та корекції порушень РЗ у цього контингенту жінок.

\section{ЛIТЕРАТУРА}

1. Антипкін Ю.Г. Репродуктивне здоров'я жінок як важлива складова покращення демографічної ситуації / Ю.Г. Антипкін // Журнал АМН України. - 2007. - Т. 13. - С. 476-485.

2. Гойда Н.Г. Репродуктивне здоров'я: стратегія, принципи, український досвід / Н.Г. Гойда, Н.Я. Жилка, Н.Є. Єнікеєва // Репродуктивное здоровье женщины. - 2004. - № 4 (20). - С. 31-34.

3. Динамика здоровья женщин, занятых в сельском хозяйстве Украины / Ю.И. Кундиев, А.Н. Каракашян, М.В. Крыжановская [и др.] // Медицина труда и промышленная экология. - 2000. № 4. - C. 5-9.

4. Жилка Н.Я. Стан репродуктивного здоров'я населення в Україні / Н.Я. Жилка // Матеріали до круглого столу «Проблеми репродуктивного здоров'я та шкільна освіта». Київ, 2003. - С. 5-35.
5. Особенности состояния репродуктивного здоровья женщин фертильного возраста - жительниц сельскохозяйственного региона / В.В. Подольский, В.В. Тетерин, В.Л. Дронова [та ін.] // Здоровье женщины. -2005 . - № 1 (21). - С. 178-183.

6. Подольский В.В. Репродуктивное здоровье женщины - важнейшая проблема современности / В.В. Подольский // Здоровье женщины. 2003. - № 1 (13). - С. 100-102.

7. Система організаційних заходів спрямованих на покращення репродуктивного здоров'я жінок фертильного віку, мешканок сільськогосподарського регіону / В.В. Подольський, В.Л. Дронова, Л.М. Піотрович [та ін.] // Актуальні питання педіатрії, акушерства та гінекології. - 2008. - № 1. - С. 27-30.

8. Чайка В.К. Основи репродуктивної медицини: практ. керівництво / В.К. Чайка. - Донецьк, 2001. - 607 с. 
Клинико-эпидемиологическая и социологическая характеристика женщин фертильного возраста с нарушениями репродуктивного здоровья В.В. Подольский, А.Л. Каграманян, Вл.В. Подольский

ГУ «Институт педиатрии, акушерства и гинекологии НАМН Украины», г. Киев, Украина Цель - определить клинико-эпидемиологическую и социологическую характеристику женщин фертильного возраста с нарушениями репродуктивного здоровья.

Пациенты и методы. Создана специальная программа исследований, разработана и напечатана анкета «Изучение состояния репродуктивного здоровья женщин фертильного возраста - жительницы сельскохозяйственного региона Украины». В качестве модели такого региона выбран Бориспольский район Киевской области. С помощью анкетирования выявлено 220 женщин с наиболее распространенными нарушениями репродуктивного здоровья. С учетом этих нарушений были выделены три группы: I группа - 80 (36,3\%) женщин с хроническими воспалительными заболеваниями половых органов, II группа - 70 (31,8\%) женщин с бесплодием, III группа - 70 (31,8\%) женщин с нарушением менструального цикла. Результаты. Наиболее частые нарушения наблюдались в I группе, частота которых составляла: хронический вагинит - 26,25\%, хронический сальпингоофорит - 27,1\%, хронический тазовый перитонит - 15,7\%; бесплодие - 31,8\%\%. Наиболее частые причины, которые приводили к бесплодию: нарушение овуляции - 52,5\%, трубно-перитонеальный фактор - 15,2\%, мужской фрактор - 13,5\%. Среди нарушений репродуктивного здоровья $(31,8 \%)$ у женщин наиболее часто оказывались ациклические маточные кровотечения - 34,3\%, менометроррагия - 33,75\%, гиперполименорея - 23,75\%

Выводы. Проведенные исследования позволили проанализировать и выделить значимость медико-социальных фракторов в нарушении репродуктивного здоровья женщин, жительниц сельскохозяйственного региона Украины.

Ключевые слова: клинико-эпидемиологические исследования, женщинь.

PERINATOLOGIYA I PEDIATRIYA.2015.2(62):32-37; doi10.15574/PP.2015.62.32

Clinico-epidemiological and sociological characteristics of women of childbearing

age with impaired reproductive health

V.V. Podolsky, A.L. Ghahramanyan, VI.V. Podolsky

SI «Institute of Pediatrics, Obstetrics and Gynecology NAMS of Ukraine», Kiev, Ukraine

Objective - to determine the clinical and epidemiological and sociological characteristics of women of childbearing age with reproductive disorders

Patients and methods. A special program of research, designed and printed questionnaire «Study of the reproductive health of women of childbearing age a resident of the agricultural region of Ukraine.» As a model of the selected region Boryspil district of Kyiv region. With the survey found 220 women with the most common reproductive disorders. In view of these violations have been divided into three groups: Group I - 80 ( $36.3 \%)$ of women with chronic inflammatory diseases of the genital organs, II group - $70(31,8 \%)$ of the women with infertility, III group - $70(31,8 \%)$ women with menstrual irregularities.

Results. The most frequent violations were observed in the I group, the frequency of which was chronic vaginitis - $26.25 \%$, chronic salpingo $27.1 \%$, chronic pelvic peritonitis - 15.7\%; Infertility $-31.8 \% \%$. The most frequent reasons that lead to infertility: ovulatory failure $-52.5 \%$, tuboperitoneal factor - 15.2\%, male factor - 13.5\%. Among reproductive disorders (31.8\%) women were often the most acyclic uterine bleeding $34.3 \%$, menometrorrhagia - $33.75 \%$, giperpolimenoreya $-23.75 \%$.

Conclusions. The research allowed to analyze and highlight the importance of medical and social factors in violation of women's reproductive health, women living in the agricultural region of Ukraine.

Сведения об авторах:

Подольский Василий Васильевич - д.мед.н., проф., руководитель отделения проблем здоровья женщины фертильного возраста ГУ «ИПАГ НАМН Украины». Адрес: г. Киев, ул. П. Майбороды, 8; тел. (044) 483-80-67.

Каграманян Армине Людвиковна - місце роботи: акушер-гинеколог «Дружньої клініки до молоді».

Адрес: г. Киев, ул. Владимирская, 43. Заочный аспирант ГУ «ИПАГ НАМН Украины».

Подольський Владимир Васильевич - к.мед.н., руководитель научной группы, ст.н.с., зав. отделения проблем здоровья женщины фертильного возраста ГУ «ИПАГ НАМН Украины». Адрес: г. Киев, ул. П. Майбороды, 8; тел. (044) 483-80-67.

Статья поступила в редакцию 5.04.2015 г. 


\section{В.С. Березенко, О.В. Царьова \\ Клініко-параклінічні аспекти перебігу хронічного вірусного гепатиту С у дитячому віці}

дУ «Інститут педіатрії, акушерства і гінекології НАМН України», м. Київ, Україна Обласна інфрекційна клінічна лікарня, м. Запоріжжя, Україна

PERINATOLOGIYA I PEDIATRIYA.2015.2(62):38-42;doi10.15574/PP.2015.62.38

Мета - вивчити особливості перебігу хронічного вірусного гепатиту С у дітей залежно від тривалості хвороби, генотипу вірусу та вірусного навантаження.

Пацієнти та методи. Обстежено 50 дітей з хронічним вірусним гепатитом С віком 3-18 років. Усім хворим проведено клінічне, лабораторне та інструментальне обстеження. Методом полімеразної ланцюгової реакції визначено генотип вірусу та вірусне навантаження. Фіброз печінки оцінено за індекcom APRI. Клінічний перебіг хронічного вірусного гепатиту C оцінено за представленістю клінічних і лабораторних синдромів протягом усього періоду захворювання, що дало змогу виділити три варіанти - безсимптомний, стабільно активний та рецидивний перебіг. Проведено статистичний аналіз отриманих даних.

Результати. Хронічний вірусний гепатит С у дітей характеризується переважно безсимптомним перебігом або 3 мінімальною клінічною симптоматикою, з низькою і мінімальною активністю гепатиту, або незміненими показниками трансаміназ. У 56\% обстежених — горизонтальний шлях інфікування (трансфузії крові та її препаратів, хірургічні маніпуляції). Встановлено, що у хворих із високим вірусним навантаженням превалює активний перебіг гепатиту. Зі збільшенням тривалості хвороби ї̈ перебіг стає більш агресивним. У дітей з активним хронічним вірусним гепатитом С і тривалістю хвороби понад 10 років за показниками індексу APRI фіброз печінки є більш виразним. Тривалість хвороби та активність гепатиту є предикторами прогресування фріброзу печінки.

Висновки. Встановлено прямий кореляційний зв'язок між величиною вірусного навантаження та активністю хронічного вірусного гепатиту С у дітей. Тривалість і активність гепатиту є предикторами прогресування фіброзу печінки в дитячому віці.

Ключові слова: діти, хронічний вірусний гепатит С, клініка, перебіг, тривалість хвороби, генотип вірусу, вірусне навантаження, фріброз.

\section{Вступ}

$\mathbf{Z}$ ронічний гепатит (ХГ) є актуальною клінічною проХблемою медицини у всьому світі. Важливість цієї патології визначається як її поширеністю, так і тяжкими наслідками прогресуючого перебігу хвороби - фіброз, цироз печінки та гепатоцелюлярна карцинома (ГЦК). Вважається, що 80-95\% захворювань на ХГ і цироз мають вірусну етіологію. У світі налічується близько 170-210 млн (близько 2,5\% населення земної кулі), інфікованих вірусом гепатиту C (HCV), крім того, 3-4 млн інфікуються щороку [6]. Гострий гепатит C закінчується хронізацією процесу у 75-85\% випадків, що більш ніж у 15 разів перевищуе аналогічний показник при гепатиті $\mathrm{B}$. За прогнозами, у 2010-2019 рр. від захворювань печінки, пов'язаних із ХГС загине майже 166 тис. осіб, у т.ч. 27200 - від ГЦК [7]. ХГС є актуальною проблемою і в педіатрії. У США та Свропі інфікування дітей HCV становить від $0,05-0,36 \%$ до 1,8\% [11]. Основним шляхом інфікування дітей вірусом гепатиту C y розвинених країнах є перинатальний. Ризик передачі HCV від матері до дитини знаходиться в межах 4,7-6,7\% [16, 18]. За даними Московської I.А. (2007), генотип та вірусне навантаження HCV у матері (більш ніж 1 млн коп./мл) відносяться до факторів підвищеного ризику перинатальної трансмісії [4]. Наявність у матері ко-інфекції $\mathrm{HIV} / \mathrm{HCV}$ підвищує шанси передачі $\mathrm{HCV}$ від матері до дитини на $90 \%$ порівняно з моноінфекцією $\mathrm{HCV}$, у таких хворих частота вертикальної передачі становить 20\% [12, 13]. Інфікування дітей HCV може відбуватись унаслідок контакту з інфікованою кров'ю у разі проведення медичних, хірургічних процедур, переливання крові та іiї компонентів, споживання ін'єкційних наркотиків, пірсінгу, татуювання та ін. У країнах, які розвиваються, превалює горизонтальний шлях інфікування гемотрансфузії та інфузії компонентів крові [17]. Існують ризики сімейно-побутової передачі $\mathrm{HCV}$-інфекції. Ризик передачі HCV від дитини до дитини в одній сім'ї становить $31 \%$, від матері до дитини - 23\%, від батька до дитини $12 \%$ [10]. Загальна інфікованість дітей вірусом гепатиту C, які знаходяться в онкогематологічному стаціонарі, становить $35-40 \%$. ХГ у цих дітей вважається первинно-хронічним у 80-90\% [3]. За даними різних авторів, ХГС у дітей має переважно м'який безсимптомний перебіг із незначним підвищенням рівня трансаміназ [1, 2, 4].

За даними літератури, прогресування фіброзу печінки в дітей з ХГС є повільнішим, ніж у дорослих. Формування цирозу печінки має місце у 1,8\% дітей з ХГС протягом

Таблиия 1

Характеристика обстежених дітей 3 хронічним гепатитом $\mathrm{C}(\mathrm{n}=50)$

\begin{tabular}{|l|c|}
\hline \multicolumn{1}{|c|}{ Показник } & Абс. (\%) \\
\hline Стать: & \\
- хлопчики & $28(56,0)$ \\
- дівчатка & $22(44,0)$ \\
\hline Вік, роки: & \\
- -5-5 & $3(6,0)$ \\
$-6-9$ & $11(22,0)$ \\
$-10-18$ & $36(72,0)$ \\
\hline Генотип вірусу HCV: & \\
- 1-й генотип & $32(64,0)$ \\
- 3-й генотип & $15(30,0)$ \\
- не типується & $3(6,0)$ \\
\hline Тривалість захворювання, роки: & \\
- <5 & $16(32,0)$ \\
- 5-10 & $14(28,0)$ \\
- >10 & $20(40,0)$ \\
\hline Шлях інфікування: & \\
- трансфузії крові та препаратів крові: & $20(40,0)$ \\
а. онкогематологічна патологія & $9(18,0)$ \\
б. в інших випадках & $11(22,0)$ \\
- оперативні втручання & $8(16,0)$ \\
- вертикальний & $6(12,0)$ \\
- сімейний контакт & $11(22,0)$ \\
- невідомий & $5(10,0)$ \\
\hline Активність ХГС: & \\
- нормальний рівень трансаміназ & $19(38,0)$ \\
- мінімальна & $16(30,0)$ \\
- низька & $14(28,0)$ \\
- помірна & $1(2,0)$ \\
\hline
\end{tabular}


9 років, порівняно з 20\% у дорослих за такий же проміжок часу [15]. Сьогодні немає єдиної точки зору на залежність виразності фіброзу в дітей з ХГС від тривалості хвороби, активності гепатиту, шляху інфікування, генотипу вірусу тощо $[9,14,15,19]$. Прогресуванню гепатиту, який викликаний HCV-інфекцією, в дітей значною мірою сприяє супутня патологія (мікстгепатити, онкогематологічні захворювання, ожиріння) [15].

Mema - вивчити особливості перебігу ХГС у дітей залежно від тривалості хвороби, генотипу вірусу та вірусного навантаження.

\section{Матеріали та методи дослідження}

Обстежено 50 дітей з ХГС віком 3-18 років. Характеристика обстежених хворих представлена в таблиці 1. Клінічний перебіг ХГС у дітей з нормальними показниками трансаміназ і відсутністю клінічної симптоматики протягом усього періоду спостереження розцінено як безсимптомний; ХГС, перебіг якого характеризувався стабільно підвищеними показниками АЛТ (>1,5 норми), - як стабільно активний; перебіг ХГС, при якому періоди підвищених показників трансаміназ чергувалися з нормальним величинами, - як рецидивний.

Для верифікації діагнозу, згідно із сучасними протоколами, усім хворим проведено клінічне, лабораторне та інструментальне обстеження. Вірусна етіологія ХГС підтверджена наявністю маркерів вірусу С методами ІФА та ПЛР. Ступінь активності процесу оцінено за рівнем АЛТ мінімальна активність характеризувалась підвищенням АЛТ до 2 норм, низька - до 5 норм, помірна - до 9 норм, висока - більш ніж 9 норм [5]. Усім хворим проведено визначення генотипу вірусу та вірусного навантаження. Вірусне навантаження оцінено як низьке при показниках PHK HCV у сироватці крові <600 $000 \mathrm{MO}$ /мл, а високе $>600000 \mathrm{MO} /$ мл. Стадія фіброзу оцінена за індексом APRI (APRI=ASTx100/(верхня межа AST)/тромбоцити $(10 \& \& \& 9 / \pi)$.

Отримані дані опрацьовані статистично з використанням пакету програм Statistica 6.1. Загально статистичний аналіз включав обчислення медіани (Mе) та інтерквартальних інтервалів (UQ-LQ). Проведено оцінку значущості середніх відмінностей у незалежних вибірках за критерієм Манна-Уїтні. Для номінальних змінних взаємозв'язок розраховано за допомогою критерію Пірсона $\left(\chi^{2}\right)$; відмінності вважались статистично значущими при $\mathrm{p}<0,05$. Для оцінки напряму, сили та значущості кореляційного зв'язку між різними ознаками використано непараметричні кореляційні аналізи Тау Кендалла і коефіцієнт Спірмена.

\section{Результати дослідження та їх обговорення}

За результатами проведеного дослідження (табл. 1), розподіл хворих за статтю був практично однаковим із незначною перевагою хлопців (56\%). Серед хворих на ХГС переважали (94\%) діти шкільного віку. Тривалість хвороби визначалась відповідно до терміну ймовірного інфікування і у $40 \%$ дітей становила $>10$ років, відсоток дітей з ХГС, які хворіли $<5$ років та $5-10$ років, був приблизно однаковим (32\% і 28\% відповідно). Середня тривалість інфікування ХГС у дітей дорівнювала 8,5 року (Me 8,5 [5-12,5]).

Детальний аналіз анамнезу хвороби дав змогу встановити шлях інфікування у 90\% хворих на ХГС. Провідним шляхом зараження в обстежених дітей були хірургічні втручання та гемотрансфузії і інфузії препаратів крові $(56 \%)$. У 9 (18\%) обстежених нами дітей інфікування
HCV відбулось під час лікування 3 приводу гострого лімфобласного лейкозу. На момент обстеження вони знаходились у ремісії лейкозу. Середня тривалість ХГС у цих дітей становила 9,3 року, а проміжок між початком онкогематологічного захворювання і проведенням даного аналізу - 10,1 року. Реціпієнтами крові та її компонентів було 40\% дітей. У 6 (12\%) хворих мав місце вертикальний шлях передачі збудника від інфікованої матері. В 11 (22\%) дітей з ХГС були сімейні контакти з хворими на гепатит C.

Гострий початок захворювання з хронізацією процесу в подальшому спостерігався у 6 (12\%) хворих дітей, які отримували препарати крові. Переважно захворювання перебігало як первинно-хронічне і діагностувалося випадково при профілактичному обстеженні або з приводу інших захворювань.

У всіх обстежених нами хворих дітей у сироватці крові методом ПЛР виявлено RNA HCV. У більшості 32 (64\%) дітей з ХГС - мав місце 1-й генотип вірусу, a 18 (36\%) дітей мали 3-й генотип. За показниками трансаміназ мінімальна та низька ступінь активності ХГС діагностувалася у 15 (30\%) і 14 (28\%) випадках відповідно. Лише в 1 дитини з 3-м генотипом спостерігалася помірна активність ХГС. У 19 (38\%) хворих на ХГС дітей не виявлено клінічних та біохімічних ознак гепатиту, що пов'язано з особливостями вірусу гепатиту C, а саме, його мінливістю зі швидким утворенням мутантних штамів і можливістю персистенції в циркулюючих макрофагах, які є недосяжними для імунного контролю [8].

За нашими даними, 23 (46\%) дитини з ХГС мали супутні захворювання органів травлення (хронічний панкреатит, хронічний гастрит, дискінезію жовчно-вивідних шляхів та ін.), які частіше зустрічались у дітей шкільного віку, ніж у молодших (у 21 (91,3\%) та 2 (8,7\%) відповідно, $\mathrm{p}<0,05)$. Патологія з боку ендокринної системи (високорослість, відставання у зрості, гіпертиреоз, гіпотиреоз) спостерігалася у 13 (26\%) дітей. У 18\% мав місце лімфобласний лейкоз у періоді ремісії. У всіх обстежених оцінювався фізичний та статевий розвиток. Затримка статевого розвитку спадково-конституційного типу відмічалася в 1 хлопчика підліткового віку. Більшість дітей мали гармонійний розвиток (IMT становив Me 19,4 [17,8-22,3]). Надлишкова маса та ожиріння I ступеня (85-95 перцентелів) спостерігалися у 4 (8\%) дітей, виразний дефіцит маси (3-10 перцентелів) - у 5 (10\%) дітей.

У клінічній картині захворювання у 28 (56\%) обстежених дітей мав місце астеновегетативний синдром (підвищена втомлюваність, емоційна лабільність тощо), в основі якого лежать хронічна неспецифічна інтоксикація, зумовлена ендотоксикозом та вегетативними розладами. Больовий синдром, виявлений у 18 (36\%) дітей з ХГС, 3 нашої точки зору, пов'язаний із супутньою патологією шлунково-кишкового тракту, яка мала місце в цих хворих. Жовтушність склер відмічалася у 6 (12\%) хворих, підвищення рівня білірубіну було переважно за рахунок непрямої фракції. У 5 з них мала місце супутня хвороба Жильбера. Враховуючи те, що в більшості обстежених дітей за показниками трансаміназ ХГС перебігав із мінімальною та низькою активністю гепатиту, ми оцінювали виразність клінічних симптомів і синдромів залежно від наявності (31 (62\%) випадок) чи відсутності (19 (38\%) випадків) активного гепатиту. Прояви ендогенної інтоксикації та малі печінкові знаки зустрічалися дещо частіше при активному гепатиті $-15(48,4 \%)$, ніж при неактивному $-6(31,6 \%)$. Лише у хворих з активним гепатитом мав місце мезенхімально-запальний синдром, 
Представленість клінічних синдромів та симптомів у дітей з хронічним гепатитом С залежно від генотипу, вірусного навантаження і тривалості хвороби, абс. (\%)

\begin{tabular}{|c|c|c|c|c|c|c|c|}
\hline \multirow{3}{*}{$\begin{array}{c}\text { Симптоми } \\
\text { та активність }\end{array}$} & \multicolumn{2}{|c|}{$\begin{array}{l}\text { Генотип } \\
\text { вірусу }\end{array}$} & \multicolumn{2}{|c|}{$\begin{array}{c}\text { Вірусне } \\
\text { навантаження, МО/мл }\end{array}$} & \multicolumn{3}{|c|}{$\begin{array}{c}\text { Тривалість } \\
\text { хвороби (років) }\end{array}$} \\
\hline & 1-й & 3-й & $>600000$ & $<600000$ & $<5$ & $5-10$ & $>10$ \\
\hline & $n=32$ & $n=18$ & $n=18$ & $n=32$ & $n=16$ & $n=14$ & $n=20$ \\
\hline Відсутність скарг & $13(41)$ & $5(33)$ & $4(22)$ & $14(44)$ & $6(38)$ & $8(57)$ & $4(20)^{\star \star}$ \\
\hline Астеновегетативний & $18(56)$ & $5(33)$ & $10(56)$ & $14(44)$ & $6(38)$ & $6(43)$ & $12(60)$ \\
\hline Диспепсичний & $7(22)$ & $4(27)$ & $4(22)$ & $10(31)$ & $3(19)$ & $4(29)$ & $7(35)$ \\
\hline Больовий абдомінальний & $12(38)$ & $5(33)$ & $3(17)$ & $15(47)^{*}$ & $3(19)$ & $6(43)$ & $9(45)$ \\
\hline Малі печінкові знаки & $3(9)$ & $1(7)$ & $1(6)$ & $4(13)$ & - & $2(14)$ & $3(15)$ \\
\hline Збільшення печінки & $10(31)$ & $6(40)$ & $2(11)$ & $15(47)^{*}$ & $3(19)$ & $5(36)$ & $9(45)$ \\
\hline
\end{tabular}

Примітки: * - відмінність достовірна (р<0,05) між групами з високим і низьким вірусним навантаженням при больовому абдомінальному синдромі $\left(\chi^{2}=4,56\right)$, збільшенні печінки $\left(\chi^{2}=6,57\right) ; * *$ - відмінність достовірна $(\mathrm{p}<0,05)$ між тривалістю хвороби 5-10 років і $>10$ років при відсутності скарг $\left(\chi^{2}=4,97\right)$.

Частота дітей з різною активністю хронічного гепатиту С залежно від генотипу, вірусного навантаження і тривалості хвороби, абс. (\%)

\begin{tabular}{|c|c|c|c|c|c|c|c|}
\hline \multirow{3}{*}{$\begin{array}{c}\text { Активність } \\
\text { гепатиту }\end{array}$} & \multicolumn{2}{|c|}{ Генотип } & \multicolumn{2}{|c|}{$\begin{array}{c}\text { Вірусне } \\
\text { навантаження, Мо/мл }\end{array}$} & \multicolumn{3}{|c|}{$\begin{array}{c}\text { Тривалість } \\
\text { хвороби (років) }\end{array}$} \\
\hline & 1-й & $3-\check{n}$ & $>600000$ & $<600000$ & $<5$ & $5-10$ & $>10$ \\
\hline & $n=32$ & $n=18$ & $n=18$ & $n=32$ & $n=16$ & $n=14$ & $\mathbf{n}=\mathbf{2 0}$ \\
\hline $\begin{array}{l}\text { Нормальний рівень } \\
\text { трансаміназ }\end{array}$ & $14(28)$ & 7 (39) & $2(11)$ & $17(53)^{*}$ & $8(50)$ & $4(29)$ & 7 (35) \\
\hline $\begin{array}{l}\text { Низька та мінімальна } \\
\text { активність }\end{array}$ & $18(36)$ & $10(55)$ & $15(83)$ & $15(47)^{*}$ & $8(50)$ & $10(71)$ & $12(60)$ \\
\hline Помірна активність & - & $1(6)$ & $1(6)$ & - & - & - & $1(5)$ \\
\hline
\end{tabular}

Примітка: *- відмінність достовірна (p<0,05) між високим і низьким вірусним навантаженням при нормальних показниках трансаміназ $\left(\chi^{2}=8,63\right)$, мінімальній і низькій активності $\left(\chi^{2}=6,38\right)$.

Частота різних варіантів перебігу хронічного гепатиту С у дітей з різною тривалістю хвороби

\begin{tabular}{|c|c|c|c|}
\hline \multirow{3}{*}{ Перебіг хвороби } & \multicolumn{3}{|c|}{ Тривалість хвороби (років) } \\
\hline & $<5$ & $5-10$ & $>10$ \\
\hline & $n=16$ & $n=14$ & $\mathrm{n}=\mathbf{2 0}$ \\
\hline Безсимптомний & $11(69)$ & $6(43)$ & $5(25)^{*}$ \\
\hline Стабільно активний & $3(19)$ & $7(50)$ & $9(45)$ \\
\hline Рецидивний & $2(12)$ & $1(7)$ & $6(30)$ \\
\hline
\end{tabular}

Примітка: *- відмінність вірогідна $(\mathbf{p}<0,05)$ між групами з тривалістю хвороби $<5$ років

$\mathrm{i}>10$ років при безсимптомному перебігу $\left(\chi^{2}=6,89\right)$.

що проявлялось підвищенням тимолової проби та $\gamma$-глобулінів у 5 (10\%) дітей.

Аналіз клінічної симптоматики залежно від генотипу вірусу, вірусного навантаження та тривалості гепатиту (табл. 2) показав, що вірогідної відмінності клінічних проявів гепатиту залежно від генотипу вірусу не було, водночас, у дітей з 3-м генотипом мала місце тенденція до збільшення частоти проявів астеновегетативного синдрому. Достовірно більшою була кількість дітей у групі 3 низьким вірусним навантаженням із проявами больового абдомінального синдрому, що пов'язано із супутньою патологією органів травлення, яка більш представлена в пацієнтів цієї групи. Більша частота дітей з проявами помірної гепатомегалії до 1-1,5 см за даними УЗД при високому вірусному навантаженні не може бути пов'язана з цим фактором, оскільки в даній групі були хворі з онкогематологічною патологією.

Звертає на себе увагу те, що зі збільшенням тривалості гепатиту достовірно зменшується кількість дітей з відсутністю скарг і зростає - 3 клінічними проявами хвороби (симптоми астеновегетативного синдрому, гепатомегалія, малі печінкові знаки). За нашими даними, у дітей з активним гепатитом із більшою частотою (11 $(36,6 \%)$ випадків) зустрічався диспепсичний синдром, ніж при неактивному

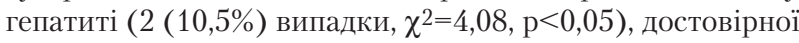
відмінності в частоті астеновегетативного синдрому між групами з активним гепатитом та хворими з нормальними показниками трансаміназ не виявлено (відповідно 15 (48\%) і 7 (36\%) дітей, $\mathrm{p}>0,05)$.

Аналіз взаємозв'язку активності ХГС в обстежених дітей (табл. 3) з факторами вірусу та тривалістю хвороби показав, що у хворих із високим вірусним навантаженням превалював активний перебіг гепатиту. Такого взаємозв'язку з тривалістю гепатиту не встановлено.

За результатами кореляційного аналізу встановлено прямий зв'язок середньої сили між активністю гепатиту та вірусним навантаженням $(\mathrm{R}=0,43, \mathrm{p}<0,05)$. Кореляції між генотипом HCV та активністю гепатиту, між активністю гепатиту та тривалістю хвороби не виявлено.

Аналіз клінічних варіантів перебігу ХГС залежно від тривалості гепатиту (табл. 4) показав, що зі збільшенням тривалості хвороби кількість дітей із безсимптомним перебігом гепатиту достовірно зменшувалася, водночас зростала частота рецидивного перебігу.

Прогресування ХГС визначається темпами формування та прогресування фіброзу, яке в обстежених нами 
Показники індексу APRI у дітей з хронічним гепатитом C

Таблиия 5 з різним вірусним навантаженням та активністю хвороби, Me (LQ-UQ)

\begin{tabular}{|c|c|c|c|c|c|}
\hline \multirow{4}{*}{ APRI } & \multicolumn{2}{|c|}{ Вірусне навантаження, МО/мл } & \multicolumn{3}{|c|}{ Активність хвороби } \\
\cline { 2 - 6 } & $<600000$ & $>600000$ & неактивний & мінімальна, низька & помірна \\
\cline { 2 - 6 } & $\mathrm{n}=18$ & $\mathrm{n}=32$ & $\mathrm{n}=19$ & $\mathrm{n}=30$ & 0,87 \\
& 0,51 & 0,88 & 0,45 & {$[0,52-1,02]$} & 1,1 \\
\hline
\end{tabular}

Показники індексу APRI у дітей з різною тривалістю

Таблиия 6 та перебігом хронічного гепатиту C, Me (LQ-UQ)

\begin{tabular}{|c|c|c|c|c|c|c|}
\hline \multirow{4}{*}{ APRI } & \multicolumn{3}{|c|}{ Перебіг хвороби } & \multicolumn{3}{|c|}{ Тривалість хвороби (років) } \\
\hline & безсимптомний & $\begin{array}{l}\text { стабільно } \\
\text { активний }\end{array}$ & рецидивний & $<5$ & $5-10$ & $>10$ \\
\hline & $\mathbf{n}=\mathbf{2 2}$ & $n=19$ & $n=9$ & $\mathrm{n}=16$ & $\mathrm{n}=14$ & $\mathbf{n}=\mathbf{2 0}$ \\
\hline & $\begin{array}{c}0,45 \\
{[0,21-0,7]}\end{array}$ & $\begin{array}{c}0,9 \\
{[0,51-1,06]}\end{array}$ & $\begin{array}{c}0,83 \\
{[0,5-1,03]}\end{array}$ & $\begin{array}{c}0,5 \\
{[0,4-0,68]}\end{array}$ & $\begin{array}{c}0,54 \\
{[0,45-1,03]}\end{array}$ & $\begin{array}{c}0,94^{*} \\
{[0,42-1,06]}\end{array}$ \\
\hline
\end{tabular}

Примітка: * - відмінність вірогідна $(\mathrm{p}<0,05)$ між групами з тривалістю хвороби $<5$ років $\mathrm{i}>10$ років.

дітей оцінювалось непрямим маркером фіброзу - індексом APRI. Аналіз показника індексу APRI у дітей з різними варіантами перебігу ХГС, генотипом вірусу, активністю гепатиту та тривалістю хвороби показав (таблиці 5 і 6 ), що в дітей 3 тривалістю ХГС $>10$ років виразність фіброзних змін у печінці була вірогідно вищою (індекс APRI у дітей з ХГС з тривалістю хвороби $<5$ років і $>10$ років відповідно становив $0,5[0,4-0,68]$ та $0,94[0,42-1,06], \mathrm{p}<0,05)$.

Проведений кореляційний аналіз (коефіцієнт Спірмена) показав наявність прямої помірної сили кореляції між індексом APRI та тривалістю хвороби $(\mathrm{R}=0,309, \mathrm{p}<0,05)$, між індексом APRI та активністю процесу $(\mathrm{R}=0,459$, p<0,05). Кореляції між індексом APRI і генотипом і вірусним навантаженням не встановлено.

\section{Висновки}

Хронічний гепатит С у дітей характеризується переважно безсимптомним перебігом із мінімальною симптоматикою, низькою і мінімальною активністю гепатиту. Частота активних форм гепатиту з тривалістю хвороби має тенденцію до зростання.

Вірусне навантаження $є$ фактором, який впливає на активність запального процесу в печінці у дітей з ХГС.

У дітей з ХГС тривалість хвороби та активність гепатиту є предикторами прогресування фіброзу печінки.

\section{ЛІТЕРАТУРА}

1. Березенко В.С. Клініко-патогенетичні особливості фіброгенезу печінки при хронічних гепатитах у дітей та шляхи його медикаментозної корекції: автореф. дис. ... д.мед.н.: 14.01.10 / В.С. Березенко; ДУ «Інститут педіатрії, акушерства і гінекології АМН України». Київ, 2007. - 37 с.

2. Денисова М.Ф. Научно-практические приоритеты детской гепатологии / М.Ф. Денисова // Сучасна гастроентерологія. - 2009. № 6 (50). - С. 115-118.

3. Крамарев С.А. Современные возможности лечения хронических вирусных гепатитов у детей / С.А. Крамарев, И.В. Шпак, Л.А. Большакова // Здоровье ребенка. - 2007. - № 4 (7). - С. 120-122.

4. Московская И.А. Болезни печени у детей / И.А. Московская; ред. М.Я. Студеникина. - Тула: Гриф и К, 2007. - 536 с.

5. Учайкин В.Ф. Вирусные гепатиты от А до TTV у детей / В.Ф. Учайкин, Н.И. Нисевич, Т.В. Чередниченко. - М.: Новая волна, 2003. - 432 с.

6. Alter M.J. Epidemiology of hepatitis C virus infection / M.J. Alter //World J. Gastroenterol. - 2007. - Vol. 13 (17). - P. 2436-2441.

7. Averhoff F.M. Global burden of hepatitis C: considerations for healthcare providers in the United States / F.M. Averhoff, N. Glass, D. Holtzman // Clin. Infect. Dis. - 2012. - Vol. 55. - P. 5-10.

8. Bach $\mathrm{N}$. The histological features of chronic hepatitis $\mathrm{C}$ and autoimmune chronic hepatitis: A comparative analysis / N. Bach. S.N. Trung, F. Schaffner // Hepatology. - 1992. - Vol. 15. - P. 572-577.
9. Chronic Hepatitis C in Children / M. Abdel-Hady, S.K. Bunn, J. Sira [et al.] // J. Viral Hepat. - 2011. - Vol. 18 (10). - P. 536-540.

10. Dissection of familian correlations in hepatitis $C$ virus (HCV) seroprevalence suggests intrafam transmission and genetic predisposition to infection / S. Plancoulaine, M.K. Mohamed, N. Arafa [et al.] // Gut. - 2008. - Vol. 57. - P. 1268-1274.

11. El-Shabrawi M.H. Burden of pediatric hepatitis C / M.H. El-Shabrawi, N.M. Kamal // World J. Gastroenterol. - 2013. Vol. 19 (44). - P. 7880-7888.

12. Gonzales-Peralta R.P. Treatment of chronic hepatitis $C$ in children / R.P. Gonzales-Peralta // Pediatr. Transpl. - 2004. - Vol. 8. - P. 639-643.

13. Impact of maternal HIV coinfection on the vertical transmission of hepatitis C virus: a meta-analysis / C.B. Polis, S.N. Shah, K.E. Johnson [et al.] // Clin. Infect. Dis. - 2007 - Vol. 44 (8). - P. 1123-1131.

14. Jhaveri R. Diagnosis and Management of Hepatitis $C$ Virus-infected Children / R. Jhaveri, G. Weinberg, C. Woods // The Pediatric Infectious Disease J. - 2011. - Vol. 30, № 11. - P. 983-985.

15. Mortada H-S. Burden of pediatric hepatitis / H-S. Mortada, M.K. Neglaa // World J. Gastroenterol. - 2013. - № 19 (44). P. 7880-7888.

16. Mother-to-child transmission of hepatitis $C$ virus: evidence for preventable peripartium transmission / D.M. Gibb, R.L. Goodall, D.T. Dunn [et al.] // Lancet. - 2000. - Vol. 356 (9233). - P. 304-307. 
17. Regino P. Gonzales-Peralta Treatment of chronic hepatitis $C$ in children / Regino P. Gonzales-Peralta // Pediatr. Transplantation. 2004. - № 8. - P. 639-643

18. Risk factors for perinatal transmission of hepatitis $\mathrm{C}$ virus $(\mathrm{HCV})$ and the natural history of HCV infection acquired in infancy / E.E. Mast,
L.Y. Hwang, D.S. Seto [et al.] // J. Infect. Dis. - 2005. - Vol. 192 (11). P. $1880-1889$.

19. Slowik M.K. Hepatitis $B$ and $C$ viruses in infants and young children. / M.K. Slowik, R. Jhaveri // Semin. Pediatr. Infect Dis. - 2005. Vol. 16. - P. 296-305.

\section{Клинико-параклинические аспекты течения хронического вирусного гепатита С в детском возрасте \\ В.С. Березенко, А.В. Царева \\ ГУ «Институт педиатрии, акушерства и гинекологии НАМН Украины», г. Киев, Украина \\ Областная инфекционная клиническая больница, г. Запорожье, Украина}

Цель - изучить особенности течения хронического вирусного гепатита С у детей в зависимости от продолжительности болезни, генотипа вируса и вирусной нагрузки.

Материалы и методы. Обследовано 50 детей с хроническим вирусным гепатитом С в возрасте 3-18 лет. Всем больным проведено клиническое, лабораторное и инструментальное обследование. Методом полимеразной цепной реакции определены генотип вируса и вирусная нагрузка. Фиброз печени оценен с помощью индекса APRI. Клиническое течение хронического вирусного гепатита С оценено по наличию клинических и лабораторных синдромов на протяжении всего периода заболевания, что позволило выделить три варианта - бессимптомное, стабильно активное и рецидивирующее течение. Проведен статистический анализ полученных данных.

Результаты. Хронический вирусный гепатит С у детей характеризуется преимущественно бессимптомным течением или с минимальной клинической симптоматикой, с низкой и минимальной активностью гепатита, или неизменными показателями трансаминаз. У 56\% обследованных — горизонтальный путь инфиццирования (транссфузии крови и ее компонентов, хирургические вмешательства). Установлено, что у больных с высокой вирусной нагрузкой преобладает активное течение гепатита. При увеличении продолжительности болезни ее течение становится более агрессивным. У детей с активным хроническим вирусным гепатитом С и длительностью болезни более 10 лет по показателям индекса APRI фриброз печени более выражен. Длительность болезни и активность гепатита - предикторы прогресса фриброза печени.

Выводы. Установлена прямая корреляционная связь между вирусной нагрузкой и активностью хронического вирусного гепатита С у детей. Длительность и активность гепатита - предикторы прогресса фиброза печени в детском возрасте.

Ключевые слова: дети, хронический вирусный гепатит С, клиника, течение, продолжительность болезни, генотип вируса, вирусная нагрузка, фиброз.

PERINATOLOGIYA I PEDIATRIYA.2015.2(62):38-42;doi10.15574/PP.2015.62.38

Clinical and paraclinical aspects of chronic hepatitis $\mathbf{C}$ in children

V.S. Berezenko, O.V. Tsaryova

SI «Institute of Pediatrics, Obstetrics and Gynecology NAMS of Ukraine», Kyiv, Ukraine

Regional Hospital of Infectious Diseases, Zaporizhzhya, Ukraine

Purpose - to study the peculiarities of chronic hepatitis $C$ in children, depending on the duration of the disease, genotype and viral load.

Materials and methods. The study involved 50 children with chronic hepatitis $C$ aged 3-18 years. All patients underwent clinical, laboratory and instrumental examination. The genotype and viral load were defined by polymerase chain reaction. Liver fibrosis was assessed using the index APRI. The clinical course of chronic hepatitis $\mathrm{C}$ was evaluated by the presence of clinical and laboratory syndromes throughout the entire period of the disease, which made it possible to identify three options - asymptomatic, active and relapsing course. The statistical analysis of the data was made.

Results. chronic hepatitis C in children is characterized to be predominantly asymptomatic or with minimal clinical symptoms, with low and minimal activity of hepatitis or transaminase rates unchanged. $56 \%$ of the survey had the horizontal route of infection (transfusion of blood and its components, surgical intervention). It was found that patients with a high viral load had predominantly active course of hepatitis. Children with active chronic hepatitis $\mathrm{C}$ and duration of the disease more than 10 years in terms of APRI index had the more pronounced course of liver fibrosis. The duration of the disease and active hepatitis are the progress predictors of liver fibrosis.

Conclusions. There is a correlation between viral load and chronic hepatitis C activity in children. The duration of HCV and active hepatitis are the progress predictors of liver fibrosis in children.

Key words: children, chronic hepatitis C, the clinic, the duration of the disease, genotype, viral load, fibrosis.

Сведения об авторах:

Березенко Валентина Сергеевна - д.мед.н., руководитель отделения детской гепатологии, учений секретарь ГУ «ИПАГ НАМН Украины». Адрес: г. Киев, ул. П. Майбороды, 8; тел. (044) 483-80-26.

Царева Елена Викторовна - врач-ординатор Запорожской областной инфекционной клинической больницы. Адрес: г. Запорожье, бул. Гвардейский, 142; тел. (061) 224-07-84. Заочный аспирант ГУ «ИПАГ НАМН Украины».

Статья поступила в редакцию 11.05 .2015 г. 


\title{
В.М. Дудник, Т.Г. Король \\ Інструментальні маркери ендотеліальної дисфункції при пурпурі Шенлейн-Геноха в дітей
}

Вінницький національний медичний університет імені М.І. Пирогова, м. Вінниця, Україна

PERINATOLOGIYA I PEDIATRIYA.2015.2(62):43-46;doi10.15574/PP.2015.62.43

\begin{abstract}
Мета — визначити інструментальні маркери ендотеліальної диссункції при пурпурі Шенлейн—Геноха в дітей.
Пацієнти та методи. Під спостереженням знаходилось 123 дитини з пурпурою Шенлейн—Геноха віком 1-18 років (середній вік становив 6,44ะ0,18 року). Враховуючи особливість перебігу пурпури Шенлейн-Геноха та клінічних проявів, проведено розподіл хворих залежно від форми (шкірна, шкірносуглобова, змішана та змішана з ураженням нирок) та активності захворювання. Для визначення наявності ендотеліальної дисфункції здійснено оцінку структурних змін та функціонального стану судинного ендотелію сонних і плечових артерій за допомогою ультразвукової допплерографії на ультразвуковому сканері «Philips HDII XE» у В-режимі датчиком лінійного формату в частотному діапазоні 5-15 МГц у стані спокою.

Результати та висновки. Встановлено, що в дітей, хворих на пурпуру Шенлейн-Геноха, достовірно частіше зустрічалася шкірна та шкірно-суглобова форма захворювання - відповідно 49 (39,8\%) та 57 (46,3\%), із переважанням II ступеня активності. За результатами ультразвукової допплерографії сонних та плечових артерій встановлено, що в пацієнтів, які мали максимальну активність захворювання, виявлено структурні зміни та порушення функціонального стану ендотелію у вигляді збільшення товщини комплексу інтима-медіа сонної артерії та плечової артерії, що перевищували в 1,3-1,5 разу аналогічні показники практично здорових дітей. Відмічено порушення гемодинамічних характеристик кровотоку по плечових артеріях

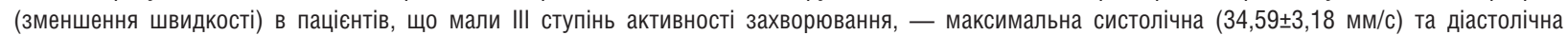

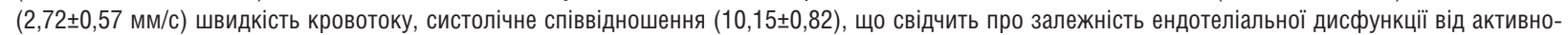
сті пурпури Шенлейн-Геноха.
\end{abstract}

Ключові слова: пурпура Шенлейн-Геноха, діти, ендотеліальна дисфункція, ультразвукова допплерографрія.

\section{Вступ}

Пурпура Шенлейн-Геноха (ПШГ) належить до групи первинних системних васкулітів iз переважним пошкодженням судин мікроциркуляторного русла [1, 2]. Патологічний процес виникає на фоні пошкодження судинної стінки, а саме ендотелію, якому притаманна секреторна, бар'єрна, гемостатична та вазомоторна функції [3], саме з цієї причини діагностика ендотеліальної дисфункції (ЕД) є важливою метою для визначення перспектив розвитку захворювання і терапевтичної тактики. Зміни рівня медіаторів і компонентів ендотеліоцитів відображають активацію клітин та пошкодження ендотеліального шару, тому не повною мірою можуть виступати як показники ЕД [5]. Існуючі методи дослідження стану судинного ендотелію поділяються на групи, які включають оцінку лабораторних маркерів ЕД та неінвазивні методи аналізу показників ендотелійзалежної вазодилятації (ЕЗВД) сонних (СА) і плечових артерій (ПА) за допомогою ультразвукової допплерографії. Застосування ультразвукової допплерографії СА та ПА з метою визначення змін діаметра судин і швидкості кровотоку вважається загальновизнаним інструментальним методом діагностики ЕД [2], що дає змогу визначати маркери ЕД при ПШГ у дітей.

Mema роботи - визначити інструментальні маркери ЕД при ПШГ у дітей.

\section{Матеріали та методи дослідження}

Для досягнення поставленої мети обстежено 123 дитини $з$ ПШГ віком 1-18 років (середній вік становив

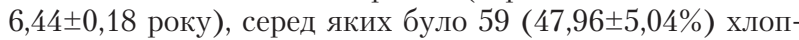
чиків і $64(52,03 \pm 4,99 \%)$ дівчинки. Враховуючи особливість перебігу ПШГ і клінічних проявів, проведено розподіл пацієнтів за формою (шкірна, шкірно-суглобова, змішана та змішана з ураженням нирок) й активністю захворювання. До контрольної групи увійшло 30 практично здорових дітей. Усім дітям з основної групи проведено клінічні та загальнолабораторні обстеження. За допомогою ультразвукової допплерографії на ультразвуковому сканері «Philips HDII XE» у В-режимі датчиком лінійного формату в частотному діапазоні 5-15 МГц у стані спокою оцінено діаметр судин, товщину комплексу інтимамедіа (КІМ) СА та ПА і показник ЕЗВД ПА для визначення ступеня прояву ЕД. За даними тесту ЦелермаєраСоренсена оцінено ЕЗВД [5]. Визначено товщину КІМ CA на відстані 2 см від біфуркації в діастолічну фазу, а КІМ ПА - у середній третині плеча. Оцінено швидкісні показники кровотоку: максимальну систолічну (Vps) та діастолічну (Ved) швидкість кровотоку, середню швидкість кровотоку (ТАMX), час прискорення (AT), середню в часі максимальну швидкість кровотоку (TAV), систолічне співвідношення (S/D), індекс периферичного опору (RI) та індекс пульсації (PI). Статистичну обробку отриманих нами результатів проведено в пакеті «STATISTICA 6.1».

\section{Результати дослідження та їх обговорення}

Серед обстежених дітей шкірний синдром зустрічався в усіх пацієнтів, хворих на ПШГ: слабо виражений у 13 (10,6\%), помірний - у 54 (43,9\%), інтенсивний у 56 (45,5\%) дітей. Такий синдром був провідним у діагностиці захворювання. Суглобовий синдром різної інтен-

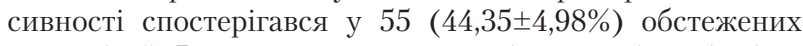
нами дітей. Встановлено, що достовірно частіше відмічалася шкірна та шкірно-суглобова форма захворювання відповідно 49 (39,8\%) та 57 (46,3\%) дітей. Найрідше зустрічалась змішана форма 3 ураженням нирок -

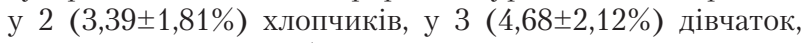
а змішана форма без ураження нирок виявлялася

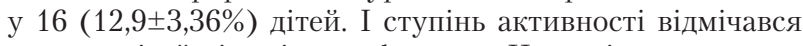
лише в дітей зі шкірною формою, II ступінь переважав при шкірно-суглобовій формі та спостерігався

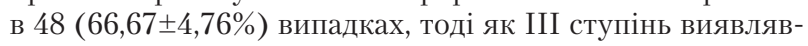


ся майже порівну при шкірно-суглобовій, змішаній та змішаній формах з ураженням нирок.

Порівнюючи діаметр СА у дітей різних вікових груп, встановлено, що найбільший діаметр СА був у дітей пубертатного віку $-7,41 \pm 0,82$ мм та 7,37 $\pm 0,84$ мм відповідно справа і зліва, що на 11-14\% більше порівняно з показниками практично здорових дітей. Порівнюючи товщину КІМ СА у дітей різного віку виявлено, що найбільше потовщення спостерігалось у дітей пубертатного віку, хворих на ПШГ, та становило 0,72 $\pm 0,20$ мм справа та $0,71 \pm 0,21$ мм зліва, що в 1,6 разу більше порівняно з показниками дітей контрольної групи. Аналіз результатів ультразвукової допплерографії ПА показав, що діаметр ПА у дітей пубертатного віку був на $22 \%$ більшим відносно показників практично здорових дітей. Крім цього, отримані нами результати дали змогу констатувати, що товщина КІМ ПА у всіх вікових групах була більшою порівняно 3 показниками практично здорових дітей: 1-3 роки - на $7 \%, 4-7$ років - на 44\%, $8-12$ років - на $44 \%, 13-18$ років на $72 \%$. Ці зміни можуть свідчити на користь ЕД при ПШГ і характеризуватись як предиктори запального процесу і ремоделювання судинного ендотелію.

Аналіз швидкісних показників кровотоку по ПА засвідчив, що середні значення Vps, Ved та S/D були достовірно нижчими в дітей, хворих на ПШГ різних вікових груп, порівняно з показниками практично здорових дітей. Водночас, слід відмітити, що показники TAMX і TAV в групі дітей віком 4-7 років були на $10-20 \%$ нижчими порівняно 3 показниками практично здорових дітей та становили $12,67 \pm 1,51 \mathrm{~mm} / \mathrm{c}$ i $12,34 \pm 1,53 \mathrm{~mm} / \mathrm{c}$ та $6,26 \pm 1,04 \mathrm{~mm} / \mathrm{c}$ і 6,08土1,09 мм/с відповідно справа і зліва. Вірогідної різниці в середніх показниках RI у обстежених дітей нами не виявлено. Тоді як показник PI у дітей основної групи різного віку був удвічі нижчим за аналогічний показник у практично здорових дітей. Аналіз змін гемодинамічних характеристик кровотоку по ПА може свідчити про структурні зміни судинної стінки, збільшення іiі жорсткості та підвищення загального периферичного опору судин у дітей, хворих на ПШГ.

Аналіз структурних змін і функціонального стану СА і ПА та швидкісних характеристик кровотоку залежно від ступеня активності ПШГ показав, що діаметр СА був достовірно меншим у дітей з III ступенем активності, що на $8-11 \%$ було меншим порівняно із середнім діаметром

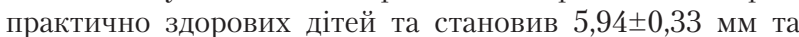

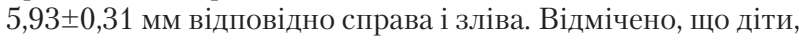
хворі на ПШГ, мали потовщення КІМ СА в 1,3-1,5 разу більше порівняно 3 показниками практично здорових дітей, але найбільш вираженим воно було при максимальному ступені активності та дорівнювало $0,65 \pm 0,24$ мм і 0,66 $\pm 0,23$ мм відповідно справа і зліва (табл. 1).

Нами виявлено тенденцію до потовщення КІМ ПА при мінімальній активності, яка набувала високих значень при максимальній активності захворювання - на 35-45\% більше порівняно з показником практично здорових дітей. Водночас, нами не відмічено прямої залежності звуження діаметра ПА від активності захворювання (табл. 2).

При аналізі швидкісних характеристик кровотоку по ПА нами відмічено достовірне сповільнення Vps , яке спостерігалось в усіх дітей, хворих на ПШГ, але більш вираже-

Показники ультразвукової допплерографії сонної артерії

Таблиия 1 залежно від активності захворювання в обстежених дітей

\begin{tabular}{|c|c|c|c|c|c|}
\hline \multicolumn{2}{|c|}{ Показник } & I ступінь & II & III & Здорові діти \\
\hline \multirow{2}{*}{ d CA (Mм) } & $\Pi$ & $6,09 \pm 0,79$ & $6,16 \pm 0,79$ & $5,94 \pm 0,33^{*}$ & $6,66 \pm 1,03$ \\
\hline & $\pi$ & $6,07 \pm 0,78$ & $6,17 \pm 0,78$ & $5,93 \pm 0,31^{*}$ & $6,44 \pm 0,89$ \\
\hline \multirow{2}{*}{$\begin{array}{l}\text { KIM CA } \\
(\mathrm{mm})\end{array}$} & $\Pi$ & $0,56 \pm 0,22$ & $0,63 \pm 0,28^{*}$ & $0,65 \pm 0,24^{*}$ & $0,44 \pm 0,28$ \\
\hline & $\pi$ & $0,57 \pm 0,17$ & $0,64 \pm 0,26^{*}$ & $0,66 \pm 0,23^{*}$ & $0,43 \pm 0,31$ \\
\hline
\end{tabular}

Примітка: *p $<0,05$ - різниця вірогідна між групами обстежених дітей.

Таблиия 2

Показники ультразвукової допплерографії плечової артерії залежно від активності захворювання в обстежених дітей

\begin{tabular}{|c|c|c|c|c|c|}
\hline \multicolumn{2}{|c|}{ Показник } & І ступінь & II & III & Здорові діти \\
\hline \multirow{2}{*}{$\mathrm{d} \sqcap A$} & $\Pi$ & $2,99 \pm 0,64$ & $3,07 \pm 0,72$ & $2,96 \pm 0,38$ & $3,24 \pm 1,05$ \\
\hline & $\pi$ & $2,98 \pm 0,61$ & $2,98 \pm 0,75$ & $2,91 \pm 0,37$ & $3,19 \pm 0,96$ \\
\hline \multirow{2}{*}{$\begin{array}{l}\text { KIM ПA } \\
(\mathrm{mm})\end{array}$} & $\Pi$ & $0,44 \pm 0,26$ & $0,52 \pm 0,28$ & $0,55 \pm 0,26$ & $0,38 \pm 0,03$ \\
\hline & $\pi$ & $0,42 \pm 0,26$ & $0,49 \pm 0,33$ & $0,50 \pm 0,24$ & $0,37 \pm 0,03$ \\
\hline \multirow{2}{*}{ Vps } & $\Pi$ & $44,30 \pm 2,89^{*}$ & $38,6 \pm 2.93^{*}$ & $34,59 \pm 3,18^{*}$ & $62,39 \pm 4,13$ \\
\hline & $\pi$ & $41,98 \pm 2,81^{*}$ & $37,7 \pm 2,95^{*}$ & $34,07 \pm 3,14^{*}$ & $58,23 \pm 4,38$ \\
\hline \multirow{2}{*}{ Ved } & $\Pi$ & $2,99 \pm 0,73$ & $2,94 \pm 0,94$ & $2,72 \pm 0,57$ & $3,32 \pm 1,73$ \\
\hline & л & $2,99 \pm 0,65$ & $2,86 \pm 0,94$ & $2,82 \pm 0,60$ & $3,11 \pm 1,49$ \\
\hline \multirow{2}{*}{ TAMX } & $\Pi$ & $15,74 \pm 1,65$ & $13,61 \pm 1,82$ & $12,21 \pm 1,83^{*}$ & $15,79 \pm 2,90$ \\
\hline & л & $14,97 \pm 1,62$ & $13,37 \pm 1,87$ & $11,71 \pm 1,66^{*}$ & $13,47 \pm 2,43$ \\
\hline \multirow{2}{*}{ AT } & $\Pi$ & $0,03 \pm 0,008$ & $0,03 \pm 0,008$ & $0,03 \pm 0,008$ & $0,05 \pm 0,01$ \\
\hline & л & $0,03 \pm 0,008$ & $0,03 \pm 0,008$ & $0,03 \pm 0,008$ & $0,05 \pm 0,01$ \\
\hline \multirow{2}{*}{ TAV } & $\Pi$ & $7,79 \pm 1,15$ & $6,79 \pm 1,3$ & $5,79 \pm 1,1^{*}$ & $7,80 \pm 2,07$ \\
\hline & л & $7,42 \pm 1,14$ & $6,69 \pm 1,3$ & $5,62 \pm 0,99^{*}$ & $6,62 \pm 1,71$ \\
\hline \multirow{2}{*}{$S / D$} & $\pi$ & $15,79 \pm 2,51^{*}$ & $15,02 \pm 3,14^{*}$ & $13,15 \pm 2,33^{*}$ & $33,61 \pm 4,80$ \\
\hline & $\pi$ & $14,42 \pm 1,98^{*}$ & $14,37 \pm 2,52^{*}$ & $12,89 \pm 2,29^{*}$ & $30,72 \pm 4,12$ \\
\hline \multirow{2}{*}{ RI } & $\Pi$ & $0,93 \pm 0,04$ & $0,92 \pm 0,04$ & $0,91 \pm 0,04$ & $0.94 \pm 0,20$ \\
\hline & $\pi$ & $0,92 \pm 0,04$ & $0,92 \pm 0,04$ & $0.92 \pm 0,04$ & $0.94 \pm 0,20$ \\
\hline \multirow{2}{*}{$\mathrm{Pl}$} & $\pi$ & $2,61 \pm 0,34^{*}$ & $2,68 \pm 1,04^{*}$ & $2,61 \pm 0,33^{*}$ & $5,70 \pm 2,02$ \\
\hline & $\pi$ & $2,59 \pm 0,31^{*}$ & $2,63 \pm 0,56^{*}$ & $2,72 \pm 0,35^{*}$ & $4.94 \pm 1,58$ \\
\hline
\end{tabular}

Примітка: ${ }^{*}-\mathrm{p}<0,05$ - різниця вірогідна між групами обстежених дітей. 
Показники ультразвукової допплерографії сонної артерії залежно від форми захворювання в обстежених дітей

\begin{tabular}{|c|c|c|c|c|c|c|}
\hline \multicolumn{2}{|c|}{ Показник } & Шкірна & $\begin{array}{c}\text { Шкірно- } \\
\text { суглобова }\end{array}$ & Змішана & $\begin{array}{c}\text { Змішана } 3 \\
\text { ураженням нирок }\end{array}$ & Здорові діти \\
\hline \multirow{2}{*}{ d CA (MM) } & $\Pi$ & $6,15 \pm 0,80$ & $6,07 \pm 0,71$ & $6,22 \pm 0,80$ & $5,85 \pm 0,24$ & $6,66 \pm 1,03$ \\
\hline & Л & $6,16 \pm 0,79$ & $6,07 \pm 0,71$ & $6,20 \pm 0,81$ & $5,82 \pm 0,26$ & $6,44 \pm 0,89$ \\
\hline \multirow{2}{*}{ KIM CA (mm) } & $\Pi$ & $0,59 \pm 0,26$ & $0,63 \pm 0,24^{*}$ & $0,65 \pm 0,23^{*}$ & $0,61 \pm 0,21^{*}$ & $0,44 \pm 0,28$ \\
\hline & Л & $0,60 \pm 0,26$ & $0.64 \pm 0,24^{*}$ & $0,65 \pm 0,23^{*}$ & $0,64 \pm 0,24^{*}$ & $0,43 \pm 0,31$ \\
\hline
\end{tabular}

Примітка: * $-\mathrm{p}<0,05$ - різниця вірогідна між групами обстежених дітей.

ні порушення були при максимальній активності захворювання, що в 1,7 разу повільніше порівняно з показником Vps

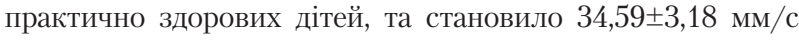

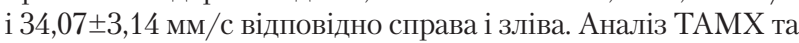
TAV свідчив, що у хворих із максимальною активністю дані показники були достовірно зниженими на 14-26\% порівняно $з$ показниками практично здорових дітей. Також нами встановлено достовірне зниження S/D у дітей, хворих на ПШГ: при мінімальній активності - у 2,1 разу, а при максимальній - у 2,5 разу $(\mathrm{p}<0,05)$. Аналіз показника PI засвідчив, що в дітей, хворих на ПШГ, спостерігалось його зниження в 2,2 разу порівняно з результатами практично здорових дітей, але нами не відмічено залежності РI від активності захворювання. Виявлені нами зміни показників швидкісного кровотоку можуть свідчити про підвищення загального периферичного опору судин, яке більш характерне для максимальної активності захворювання.

Аналіз структурних змін та функціонального стану ендотелію СА залежно від форми захворювання показав, що достовірне потовщення КІМ СА спостерігалось при

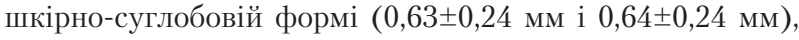
змішаній формі $(0,65 \pm 0,23$ мм справа і зліва) та змішаній формі з ураженням нирок $(0,61 \pm 0,21$ мм і $0,64 \pm 0,24$ мм) відповідно справа і зліва порівняно з показником КІМ СА

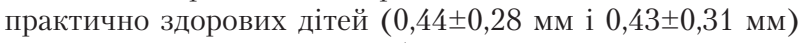
відповідно справа і зліва (табл. 3).

Аналізуючи структурні зміни судинного ендотелію та швидкісні характеристики кровотоку по ПА залежно від форми захворювання, нами зареєстровано потовщення

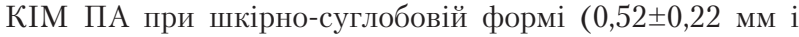

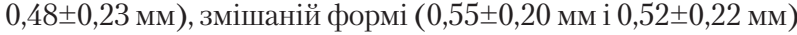
та змішаній формі 3 ураженням нирок $(0,52 \pm 0,21$ мм

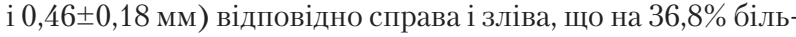
ше відносно показників практично здорових дітей.

Швидкісні характеристики кровотоку по ПА (табл. 4) дали змогу судити про підвищення загального периферичного опору судини, але суттєво не відрізнялись залежно від форми захворювання.

Однак слід зазначити, що при змішаній формі з ураженням нирок спостерігались виражені зміни: Vps -

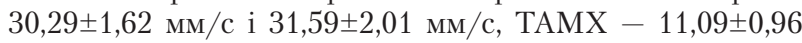
(в 1,4-2 рази менше порівняно 3 показниками дітей контрольної групи), АT - 0,03 $\pm 0,008, \mathrm{TAV}-5,54 \pm 0,67$ (в 1,4-1,7 разу менше відповідно), S/D - 10,15 $\pm 0,82$ i $11,16 \pm 0,79$ (в 2,7-3,3 разу менше відповідно), PI -

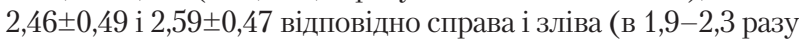
менше відповідно).

\section{Висновки}

Інструментальними маркерами ендотеліальної дисфункції у дітей, хворих на ПШГ, є діаметр СА і ПА та товщина КІМ СА і КІМ ПА, котрі залежать від віку пацієнтів та активності захворювання. У дітей пубертатного віку товщина КIM CA і ПА на 57-72\% більша за аналогічні показники в дітей інших вікових груп та практично здорових, що може свідчити про наявність запального процесу і ремоделювання судинного русла.

При зростанні активності ПШГ спостерігається потовщення КIM СА та ПА (в 1,3-1,5 разу) порівняно 3 показниками практично здорових дітей, що свідчить про

Показники ультразвукової допплерографії плечової артерії

Таблиия 4 залежно від форми захворювання в обстежених дітей

\begin{tabular}{|c|c|c|c|c|c|c|}
\hline \multicolumn{2}{|c|}{ Показник } & \multirow{2}{*}{$\begin{array}{c}\text { Шкірна } \\
3,06 \pm 0,67\end{array}$} & \multirow{2}{*}{$\begin{array}{c}\begin{array}{c}\text { Шкірно- } \\
\text { суглобова }\end{array} \\
3.02 \pm 0,68 \\
\end{array}$} & \multirow{2}{*}{$\begin{array}{c}\text { 3мішана } \\
3,12 \pm 0.64\end{array}$} & \multirow{2}{*}{$\begin{array}{c}\text { Змішана } 3 \\
\text { ураженням нирок } \\
2,85 \pm 0,36\end{array}$} & \multirow{2}{*}{$\begin{array}{c}\text { Здорові діти } \\
3,24 \pm 1,05\end{array}$} \\
\hline & $\Pi$ & & & & & \\
\hline dIIA & Л & $3,05 \pm 0,67$ & $2.92 \pm 0,72$ & $3.07 \pm 0,64$ & $2,82 \pm 0,37$ & $3,19 \pm 0,96$ \\
\hline \multirow{2}{*}{$\mathrm{KIM} \sqcap \mathrm{A}(\mathrm{mm})$} & $\Pi$ & $0,47 \pm 0.28$ & $0,52 \pm 0,22^{*}$ & $0,55 \pm 0,20^{*}$ & $0,52 \pm 0,21^{*}$ & $0,38 \pm 0,03$ \\
\hline & Л & $0,45 \pm 0,26$ & $0.48 \pm 0,23^{*}$ & $0,52 \pm 0,22^{*}$ & $0,46 \pm 0,18^{*}$ & $0,37 \pm 0,03$ \\
\hline \multirow{2}{*}{ Vps } & $\Pi$ & $43,27 \pm 2,91^{*}$ & $36,75 \pm 2,96^{*}$ & $38,32 \pm 3.11^{*}$ & $30,29 \pm 1,62^{*}$ & $62,39 \pm 4,13$ \\
\hline & Л & $41,97 \pm 2,87^{*}$ & $35,87 \pm 2,87^{*}$ & $37,05 \pm 3.04^{*}$ & $31,59 \pm 2,01^{*}$ & $58,23 \pm 4,38$ \\
\hline \multirow{2}{*}{ Ved } & $\Pi$ & $2,99 \pm 0,67$ & $2,97 \pm 0.96$ & $2,60 \pm 0,62$ & $2,98 \pm 0,88$ & $3,32 \pm 1,73$ \\
\hline & Л & $2,96 \pm 0,64$ & $2,88 \pm 0,98$ & $2,81 \pm 0,59$ & $2,84 \pm 0,79$ & $3,11 \pm 1,49$ \\
\hline \multirow{2}{*}{ TAMX } & $\Pi$ & $15,38 \pm 1,66$ & $13,17 \pm 1,83$ & $13,39 \pm 1,86$ & $11,09 \pm 0,96^{*}$ & $15,79 \pm 2,90$ \\
\hline & Л & $14,95 \pm 1,64$ & $12,74 \pm 1,85$ & $12,87 \pm 1,86$ & $11,09 \pm 0,96^{*}$ & $13,47 \pm 2,43$ \\
\hline \multirow[b]{2}{*}{ AT } & $\Pi$ & $0,03 \pm 0,008$ & $0,03 \pm 0,008$ & $0,03 \pm 0,008$ & $0,03 \pm 0,008$ & $0,05 \pm 0,01$ \\
\hline & Л & $0,03 \pm 0,008$ & $0,03 \pm 0,008$ & $0,03 \pm 0.008$ & $0,03 \pm 0,008$ & $0,05 \pm 0,01$ \\
\hline \multirow{2}{*}{ TAV } & $\Pi$ & $7,56 \pm 1,16$ & $6,57 \pm 1,30$ & $6,42 \pm 1,25$ & $5,54 \pm 0,67^{*}$ & $7,80 \pm 2,07$ \\
\hline & Л & $7,36 \pm 1,14$ & $6,39 \pm 1,29$ & $6,22 \pm 1,26$ & $5,54 \pm 0.67^{*}$ & $6,62 \pm 1,71$ \\
\hline \multirow{2}{*}{$S / D$} & $\Pi$ & $15,13 \pm 2,34^{*}$ & $13,82 \pm 2,55^{*}$ & $15,31 \pm 2,33^{*}$ & $10,15 \pm 0,82^{*}$ & $33,61 \pm 4,80$ \\
\hline & Л & $14,52 \pm 2,37^{*}$ & $13,44 \pm 2,39^{*}$ & $14,44 \pm 2,29^{*}$ & $11,16 \pm 0.79^{*}$ & $30,72 \pm 4,12$ \\
\hline \multirow{2}{*}{ RI } & $\Pi$ & $0,93 \pm 0,14$ & $0,92 \pm 0,14$ & $0,92 \pm 0,14$ & $0.90 \pm 0,15$ & $0.94 \pm 0,20$ \\
\hline & Л & $0,92 \pm 0.14$ & $0,92 \pm 0,14$ & $0.93 \pm 0,14$ & $0.91 \pm 0,13$ & $0.94 \pm 0,20$ \\
\hline \multirow{2}{*}{ PI } & $\Pi$ & $2,60 \pm 0,35^{*}$ & $2,55 \pm 0,60^{*}$ & $2.67 \pm 0,72^{*}$ & $2,46 \pm 0,49^{*}$ & $5,70 \pm 2,02$ \\
\hline & Л & $2,59 \pm 0,36^{*}$ & $2,60 \pm 0,57^{*}$ & $2,73 \pm 0,71^{*}$ & $2,59 \pm 0,47^{*}$ & $4.94 \pm 1,58$ \\
\hline
\end{tabular}

Примітка: * ${ }^{*}<0,05$ - різниця вірогідна між групами обстежених дітей. 
вплив активності захворювання на структурний стан судинного ендотелію.

Існує залежність не лише структурних змін судинного ендотелію, але й гемодинамічних характеристик кровото- ку від активності захворювання, а саме, сповільнення кровотоку Vps (в 1,7 разу), S/D (в 1,2-2,5 разу), що може свідчити про вплив активності ПШГ на жорсткість і загальний периферичний опір судин.

\section{ЛІТЕРАТУРА}

1. Бережний В.В. Педіатрія: національний підручник В.В. Бережний. - Київ, 2013. - С. 906-910.

2. Визначення ендотеліальної дисфункції судин у хворих на цироз печінки з портальною гіпертензією та гепаторенальним синдромом II типу / Є.С. Сірчак, Х.В. Футько, В.І. Русин, Е.І. Архій // Світ медицини та біології. - 2010. - № 2. - С. 155.

3. Признаки гиперкоагуляции и акимвации фибринолиза у больных у больных гранулематозом Вегенера и пурпурой Шенлейн-Геноха / Л.А. Стрижаков, Е.П. Чегаева, О.Г. Кривошеев [и др.] // Клиническая медицина. - 2012. - № 5. - С. 43-45.
4. Третьякова О.С. Пурпура Шенлейн-Геноха у детей: клинико-диагностические подходы / О.С. Третьякова // Дитячий лікар. - 2011. № 5. - C. 8-15.

5. Minchali R.D. Transport across the endothelium: regulation of endothelial permeability / R.D. Minchali, A.B. Malik // Handb. Exp. Pharmacol. 2006. - Vol. 176 (1). - P. 107-144.

6. Non-invasive detection of endothelial dysfunction in children and adult at risk of atherosclerosis / D. Celermajer, K. Sorensen, V. Gooch [et al.] // Lancet. - 1992. Vol. 340. - P. 1111-1115.

\section{Инструментальные маркеры эндотелиальной дисфункции при пурпуре Шенлейн-Геноха у детей В.М. Дудник, Т.Г. Король}

Винницкий национальный медицинский университет имени М.И. Пирогова, г. Винница, Украина

Цель - определить инструментальные маркеры эндотелиальной дисфункции при пурпуре Шенлейн-Геноха у детей.

Пациенты и методы. Под наблюдением находилось 123 ребенка с пурпурой Шенлейн—Геноха в возрасте 1-18 лет (средний возраст составлял 6,44ะ0,18 года). Учитывая особенности течения пурпуры Шенлейн—Геноха и клинических проявлений, проведено распределение больных в зависимости от фрормы (кожная, кожно-суставная, смешанная и смешанная с поражением почек) и активности заболевания. Для определения наличия эндотелиальной диссрункции проведена оценка структурных изменений и функционального состояния сосудистого эндотелия сонных и плечевых артерий с помощью ультразвуковой допплерографии на ультразвуковом сканере «Philips HDII XE» в B-режиме датчиком линейного формата в частотном диапазоне 5-15 МГц в состоянии покоя.

Результаты и выводы. Установлено, что у детей с пурпурой Шенлейн-Геноха достоверно чаще встречается кожная и кожно-суставная фрорма заболевания - соответственно 49 (39,8\%) и 57 (46,3\%) детей, с преобладанием II степени активности. По результатам ультразвуковой допплерографии сонных и плечевых артерий установлено, что у пациентов, которые имели максимальную активность заболевания, выявлены структурные изменения и нарушения функционального состояния эндотелия - толщина комплекса интима-медиа сонной и плечевой артерий в 1,3-1,5 раза больше аналогичных показателей практически здоровых детей. Отмечены нарушения гемодинамических характеристик кровотока по плечевым артериям (уменьшение скорости) у пациентов с III степенью активности заболевания - максимальная систолическая $(34,59 \pm 3,18$ мм/с) и диастолическая $(2,72 \pm 0,57$ мм/с) скорость кровотока, систолическое соотношение $(10,15 \pm 0,82)$, что свидетельствует о зависимости эндотелиальной диссфункции от активности пурпуры Шенлейн-Геноха.

Ключевые слова: пурпура Шенлейн—Геноха, дети, эндотелиальная дисфункция, ультразвуковая допплерография.

PERINATOLOGIYA I PEDIATRIYA.2015.2(62):43-46; doi10.15574/PP.2015.62.43

Instumentalni markers of endothelial dysfunction in Schonlein-Henoch purpura in children

V.M. Dudnyk, T.G. Korol

Vinnytsia National Medical University, Vinnytsia, Ukraine

Purpose - to determine the instrumental markers of endothelial dysfunction in Schonlein-Genoch purpura in children.

Patients and methods. 123 children with Schonlein-Henoch purpura aged 1 to 18 years (mean age $6.44 \pm 0.18$ years) were under the supervision. Given the current feature SHP and clinical manifestations organized distribution of patients depending on the form (skin, skin-articular, mixed and blended with renal disease) and disease activity. To determine the presence of endothelial dysfunction, an assessment of structural changes and functional state of the vascular endothelium of the carotid artery and brachial using Doppler ultrasound scanner in «Philips HDII XE» in B-mode sensor linear format in the frequency range from 5 to $15 \mathrm{MHz}$ at rest .

Results and conclusions. Found that in children with SHP was significantly more common skin and skin — articular form of the disease - 49 (39.8\%) and $57(46.3 \%)$ children, respectively, with a predominance of II degree of activity. As a result of Doppler ultrasound of the carotid artery and brachial we found that patients who had maximum activity of the disease, and found structural changes of the functional state of the endothelium - the IM thickness CA and BA 1.3-1.5 times more than in healthy children. Reported violations hemodynamic characteristics of blood flow in the brachial artery (deceleration) patients had grade III disease activity — Vps $(34.59 \pm 3.18 \mathrm{~mm} / \mathrm{s})$, Ved $(2.72 \pm 0.57 \mathrm{~mm} / \mathrm{s}), \mathrm{S} / \mathrm{D}(10.15 \pm 0.82)$, indicating a dependence on the activity of endothelial dysfunction Schonlein-Henoch purpura.

Key words: Schonlein—Henoch purpura, children, endothelial dysfunction, Doppler ultrasound.

Сведения об авторах:

Дудник Вероника Михайловна - д.мед.н., проф., зав. каф. педиатрии №2 Винницкого НМУ им. М.И. Пирогова.

Адрес: г. Винница, ул. Пирогова М.І, 46; e-mail: dudnykv@mail.ru.

Король Татьяна Григорьевна - ассистент каф. педиатрии №2 Винницкого НМУ им. М.И. Пирогова.

Адрес: г. Винница, ул. Пирогова М.I, 46; e-mail: tanya.korol.75@mail.ru.

Статья поступила в редакцию 11.04.2015 г. 


\section{Л.О. Левадна \\ До проблеми прорізування зубів у дітей}

Національний медичний університет імені О.О. Богомольця, м. Київ, Україна

PERINATOLOGIYA I PEDIATRIYA.2015.2(62):47-51;doi10.15574/PP.2015.62.47

Мета - виявити основні зміни в організмі дитини, які супроводжують прорізування молочних зубів.

Пацієнти та методи. При обстеженні дітей використовувалися дані анамнезу та лабораторна діагностика. Спостерігалося 30 дітей віком від 6 місяців до 2 років, в яких прорізувалися молочні зуби.

Результати. Установлено, що в більшості дітей виявлявся симптомокомплекс прорізування молочних зубів, який включав підвищення температури тіла, послаблення випорожнень, нежить. Окрім того, у всіх обстежених дітей відмічались слинотеча, плаксивість, порушення сну, неспокій, зниження апетиту. Такі явища переважно спостерігалися в дітей, які мали патологічний перебіг антенатального та інтранатального періодів. При оцінці лабораторних даних у дітей у загальному аналізі крові виявлялося підвищення ШОЕ в межах 15-17 мм/год у 12 (60\%) дітей, лейкоцитоз зі зсувом лейкоцитарної формули вліво - у 10 (50\%) дітей, лімфоцитоз - у 8 (40\%) дітей. Такі зміни пов'язані, ймовірніше, з особливостями фрункціонування та становлення імунної системи. Усі діти, батьки яких звернулися стосовно скарг у своїх дітей на нежить, були оглянуті ЛоР-лікарем, який не виявив жодної гострої патології з боку даної системи.

Висновки. Прорізування зубів є фрізіологічним процесом і в більшості дітей не викликає жодних серйозних ускладнень та скарг. Діти з будь-якими скаргами в період прорізування зубів повинні бути оглянуті лікарем для виключення патології та для ії своєчасного лікування.

Ключові слова: діти, зуби, синдром прорізування.

\section{Вступ}

$\prod$ еріод прорізування молочних зубів є досить та їі батьків, який спричиняє багато тривог. Дотепер не тільки серед батьків, але й серед частини медичних працівників існує думка, що саме прорізування зубів може обумовлювати, крім болю, набряклість ясен, слинотечу, лихоманку, діарею тощо.

Зазвичай дитина віком до 1 року має 8 різців, а приблизно до 3 років у неї завершується прорізування всіх 20 молочних зубів. Незначні відхилення від цих термінів не мають викликати тривогу, оскільки цей процес дуже індивідуальний і залежить від багатьох факторів: характеру харчування матері під час вагітності, якості споживаної води, раціону харчування самої дитини, клімато-географічної зони. Особливу роль відіграє спадковість, оскільки існує генетичний зв'язок між тим, як і коли з'являються зуби в дітей та їхніх найближчих родичів (особливо по лінії матері)

Хоча прорізування зубів - це природний фізіологічний процес, майже всі діти в цей період відчувають дискомфорт і занепокоєння, стають вередливими. Серед педіатрів сьогодні існує практично одностайна думка, що симптоми прорізування зубів не є специфічними для даного стану.

Peretz B. et al. [14] спостерігали в клініці 585 дітей (145 - 3 прорізуванням зубів, $357-$ контрольна група поза періодом прорізування) віком 6-30 місяців і показали, що у 40\% дітей основної групи прорізування зубів було безсимптомним, а у $60 \%$ мав місце хоча б один із таких симптомів: слинотеча $(32 \%)$, лихоманка $>38,0^{\circ} \mathrm{C}$ (25\%), діарея (35\%). Водночас, у 93\% дітей контрольної групи спостерігалися такі ж ознаки.

Cunha R.F. et al. [13], проаналізувавши карти огляду 1813 дітей віком 0-3 років у стоматологічній клініці, повідомили, що 95\% дітей мали свербіж ясен і дратівливість, пов'язані з прорізуванням зубів.

Swann I.L. [11], оглянувши 50 дітей, що надійшли в лікарню зі скаргами батьків на симптоми прорізування зубів, встановив, що у 48 з них (96\%) не було відхилень у стані здоров'я, але в двох випадках діагностовано важкі інфекції, в тому числі у одного малюка - бактеріальний менінгіт.

Tighe M. [15] провів мета-аналіз 21 статті щодо прорізування зубів (глибина опрацювання - 1966-2006) і лише в 6 роботах виявив повідомлення про на наявність системних симптомів, які могли бути пов'язані з прорізуванням зубів, однак ці симптоми могли бути зумовлені іншими причинами.

Одне 3 найбільших на сьогодні проспективних досліджень, де протягом 7 місяців спостерігали за 125 немовлятами, починаючи з віку 4 місяців до 1 року, виконали Macknin M.L. et al. [12]. Встановлено, що такі симптоми, як бажання гризти/кусати різні предмети, слинотеча, висипання на обличчі, дратівливість і підвищення температури тіла (у всіх $<38,3^{\circ} \mathrm{C}$ ) відзначалися значно частіше за 4 дні до появи зуба, у день прорізування і через 3 дні після цього, що дало змогу авторам назвати це «8-денне вікно» періодом прорізування. Вони підкреслили, що діарея, кашель, блювання, лихоманка $>38,5^{\circ} \mathrm{C}$ не пов'язані 3 прорізуванням зубів, а найчастіше обумовлені інфекцією. У даному проспективному дослідженні автори не виявили симптомів, які можуть «пророкувати» прорізування зубів.

До переліку симптомів, які асоціюються з прорізуванням зубів або приєднанням інтеркурентних захворювань, на тлі яких відбуватиметься ця подія, слід додати ряд анатомо-фізіологічних особливостей дітей грудного та раннього віку: стан імунної системи (дозрівання протиінфекційного імунітету закінчується до 1,5-3 років, коли завершується переорієнтація імунної відповіді з Th-2 на Th-1 тип імунного реагування; висока проліферативна активність лімфоцитів із переважанням фракції наївних лімфоцитів, незавершений фагоцитоз, зниження вмісту антитіл, отриманих дитиною внутрішньоутробно від матері, низька продукція секреторного компонента IgA та ін.); нестабільність складу біоценозу слизової оболонки порожнини рота, бронхів і легенів; будова тубарного апарату тощо $[1,4,5]$.

Ознаки та симптоми, які часто приписуються прорізуванню зубів [2, 7, 8, 12, 14, 16], такі:

- надмірне слиновиділення;

- пероральне висипання;

- бажання гризти різні тверді предмети або тримати пальці в роті;

- збудження;

- розлад кишечнику, включаючи діарею, запори, рідкі випорожнення;

- кишкові кольки;

- кашель, нежить;

- потирання вух, щоки; 
- почервоніння обличчя;

- лихоманка не вище $38^{\circ} \mathrm{C}$;

- запалення / набряклість ясен;

- зниження апетиту / відмова від рідини;

- нездужання;

- пронизливий плач;

- хворобливість і набряклість рота;

- неприємний запах сечі;

- проблеми з диханням, включаючи нежить, бронхоспазм, гіперемію та інфекції горла;

- середній отит;

- первинний герпетичний гінгівостоматит;

- виражене занепокоєння;

- тривалий плач;

- судоми;

- шкірне висипання;

- порушення сну, безсоння;

- блювання;

- втрата ваги.

Як вже зазначалося раніше, діагноз прорізування зубів - це діагноз виключення.

Розвиток зубів починається ще в утробі матері з 6-го тижня вагітності, коли в яснах плода розвиваються зачатки зубів.

Усупереч поширеному переконанню, що зуби повинні прорізуватись в якийсь певний термін і в строгій послідовності, насправді не існує жодних жорстких термінів і чіткого порядку появи зубів у дітей. Поява зубів, як і інші параметри розвитку дитини (набір ваги, зростання у висоту, закриття тім'ячка), дуже варіює залежно від особливостей організму дитини та їі батьків.

Наприклад, зуби можуть прорізатися в новонародженої дитини (приблизно 1 дитина з 2000 малюків народжується вже з одним або двома зубами) або, рідко, можуть взагалі бути відсутніми до віку 15-16 місяців і більше.

У переважної більшості дітей перші зуби з'являються в 4-7 місяців, тому невеликі відхилення від цього терміну не повинні турбувати батьків.

Багато фахівців вважають, що існує генетичний зв'язок між тим, як і коли з'являються зуби в батьків (особливо в матері) і в їхніх дітей. Тому, якщо в батьків зуби з'явилися пізно, існує велика ймовірність того, що і в дітей зуби також з'являться пізніше, ніж в їхніх однолітків.

Як правило, зуби з'являються в такому порядку: першими прорізуються різці (верхні і нижні), потім - перші великі корінні зуби (верхні і нижні), тоді - ікла (верхні i нижні) i, нарешті, другі великі корінні зуби (верхні і нижні). До 3-річного віку дитина повинна мати повний ряд $з 20$ зубів, які не мають випадати приблизно до 6 років, коли будуть готові прорізуватись постійні зуби.

Прорізування зубів починається, за середньостатистичними даними, 36 місяців. Сучасна тенденція до прорізування знижує ці терміни, і в дітей інколи зуби прорізуються раніше, приблизно з $4-5$ місяців. Але в який би час зуб не прорізувався, у дитини спостерігається так званий «синдром прорізування зубів». Синдром це збірне поняття, яке включає симптоми, відповідні саме цьому процесу. Симптоми - це явища, які можуть виникати під час прорізування, тривати певний час і приносити багато неприємностей не тільки самому малюкові, але і його батькам. У період прорізування зубів у малюка може спостерігатися лихоманка, примхливість, зниження апетиту, запалення ясен, послаблення стільця, підвищена стомлюваність, зміна настрою.
Думки лікарів щодо того, чи викликає прорізування зубів такі симптоми, як діарея, нежить, вологий кашель і підвищення температури тіла, різняться.

Незважаючи на те, що в певних випадках зв'язок між погіршенням стану дитини і появою зубів практично очевидний, більшість лікарів не включають підвищення температури тіла, нежить, кашель і діарею до списку можливих проявів прорізування зубів. Таке ставлення має логічне пояснення: у багатьох випадках прорізування зубів у дітей може тривати перші 2-3 роки життя і збігається з періодом найбільшого ризику різних інфекцій, у зв'язку з чим неправильно і небезпечно «списувати» кожен епізод температури, кашлю, діареї або нежиті на прорізування зубів.

Проте нетривале підвищення температури, нежить, незначна діарея і вологий кашель на тлі прорізування зубів можливі і спостерігаються досить часто.

Такі провісники, як зниження апетиту, примхливість, можуть з'явитися раніше за явні прояви прорізування зубів. За такими ознаками іноді можна запідозрити наближення прорізування.

Втрата апетиту, пов'язана з небажанням травмувати ясна і провокувати неприємні відчуття в місці прорізування такі, як бажання гризти/кусати різні предмети біль, слинотеча. Саме з цієї причини дитина, свідомо оберігаючи себе, намагається не травмувати і не дратувати запалені ясна.

Підвищення температури може приводити до стомлюваності дитини, такі діти потребують додаткового сну вдень і підвищеної уваги.

Зміна настрою так само властива дітям у такий складний для них період, і часом ця зміна занадто різка. При затиханні неприємних відчуттів у дитини повертається гарний настрій, нормалізується апетит, однак частіше синдром прорізування зберігається на весь час, поки зуби з'являться в порожнині рота. Після прорізування коронки зуба всі симптоми поступово зникають, і стан дитини стабілізується.

Підвищення температури під час прорізування зубів пов'язане 3 виділенням значної кількості біологічно активних речовин у зоні росту зуба. У більшості випадків підвищення температури при прорізуванні зубів не перевищує $38,5^{\circ} \mathrm{C}-39^{\circ} \mathrm{C}$ і триває не більше $1-2$ днів.

Послаблення випорожнень під час прорізування зубів пояснюється сильним слиновиділенням (дитина проковтує багато слини) і прискоренням перистальтики кишечнику. Випороження на тлі прорізування зубів, як правило, водянисті, не частіші ніж 2-3 рази на добу, і такі ознаки тривають не більше 1-3 днів.

При прорізуванні верхніх різців та іклів можуть бути виділення з носу, але вони не в'язкі, а їх колір і консистенція нагадують воду. Нежить під час прорізування зубів пояснюється підвищеним виділенням слизу залозами порожнини носа. Нежить на тлі прорізування зубів не дуже рясний і триває не більше 3-4 днів.

Запалення ясен обумовлено фізіологічним процесом проходження молочного зуба в товщі щелепи і розриву ясна для його становлення в порожнині рота. При прорізуванні малюк може відчувати шквал відчуттів і в більшості випадків не зовсім приємних. Постійне роздратування і тиск зсередини викликає відчуття печіння, іноді поколювання. Постійний свербіж так само супроводжує малюка на всьому протязі прорізування зубів. Саме ці відчуття пояснюють прагнення малюка все гризти, як би «чухати» ясна всіма предметами, які трапляються під руку.

У порожнині рота є фактори, які стабілізують запалення і допомагають організму відновитися. Це звичайно слиновиділення, яке під час прорізування зубів виникає 
в значній кількості. У складі слини присутній лізоцим, який має протизапальну і антибактеріальну дію. Саме цей фермент стабілізує стан у порожнині рота і не тільки в момент прорізування зубів, він певною мірою попереджує розвиток карієсу і запальних захворювань.

Предмети, які дитина тягне до рота, зазвичай не зовсім чисті, і слина певною мірою дезінфікує їх та протистоїть впливу мікроорганізмів.

Вологий кашель під час прорізування зубів пояснюється скупченням у горлі слини, що виділяється в значній кількості під час прорізування. Вологий кашель у цей період не частий, посилюється в положенні дитини лежачи і минає протягом 2-3 днів.

Як зазначалося вище, якщо в дитини з'явилися такі симптоми, як лихоманка, сильний нежить, діарея або інші ознаки захворювання, які тривають понад 1-2 днів, дитина потребує огляду лікарем, тому що ці симптоми можуть бути викликані таким серйозним захворюванням, як запалення середнього вуха, харчове отруєння, вірусна інфекція тощо. Відомо, що організм маленької дитини ще не здатний справлятися з багатьма хворобами, тому за явних ознак захворювання краще зайвий раз звернутися до лікаря, ніж звернутися занадто пізно.

3 усіх вищеописаних проявів прорізування зубів слід лікувати лише лихоманку і тільки в разі іiї підвищення понад $38,5^{\circ} \mathrm{C}$. Нежить, кашель або діарея викликані прорізуванням зубів, не потребують жодного лікування.

Нами обстежено 20 дітей віком від 6 місяців до 2 років (основна група), в яких прорізувалися ті чи інші молочні зуби. Причиною звернення до поліклініки були скарги батьків на підвищення температури тіла, послаблення випорожнень, нежить. Окрім того, у всіх обстежених дітей відмічались слинотеча, плаксивість, порушення сну, неспокій, зниження апетиту. Водночас, ми спостерігали 10 дітей віком від 9 місяців до 1 року (група порівняння), в яких також прорізувалися зуби, однак без будь-яких скарг батьків.

Усі діти, як основної, так і порівняльної груп, були оглянуті ЛОР-лікарем, а також були проведені лабораторні обстеження - загальний аналіз крові, загальний аналіз сечі, копрограма.

Преморбідний фон обстежених дітей був обтяжений такими факторами, як загроза переривання вагітності у $14(66,7 \%)$, гестоз першої та другої половини у 7 (33,3\%), анемія під час вагітності - у 10 (50\%), екстрагенітальна патологія (хронічний тонзиліт, міопія, хронічний бронхіт), а також хворобами матері під час вагітності (гострі респіраторні вірусні інфекції - ГРВІ з підвищенням температури до фебрильних цифр, гострий бронхіт, гострий пієлонефрит) і генітальною патологією. У дітей групи порівняння дані значно відрізнялися: лише у 5 (50\%) жінок була діагностована під час вагітності анемія легкого ступеня.

У 3 матерів дітей основної групи під час пологів відмічалося крайове відшарування плаценти, що призвело до народження дітей шляхом кесаревого розтину, у 5 (25\%) дітей під час народження спостерігалася асфіксія першого ступеня, у 2 (10\%) дітей діагностувалася кефалогематома. У матерів дітей порівняльної групи пологи мали фізіологічний перебіг.

У 2 (10\%) жінок основної групи під час вагітності була травма живота, що призвела до відшарування плаценти, внутрішньоутробної гіпоксії, передчасних пологів та народження дитини із затримкою внутрішньоутробного розвитку.

Особливості перебігу вагітності та пологів наведено в таблиці 1.

Особливості перебігу вагітності та пологів
\begin{tabular}{|l|c|c|}
\hline \multicolumn{1}{|c|}{ Показник } & $\begin{array}{c}\text { Основна } \\
\text { група (n=20) }\end{array}$ & $\begin{array}{c}\text { Група } \\
\text { порівняння } \\
(\mathbf{n = 1 0 )}\end{array}$ \\
\hline $\begin{array}{l}\text { Загроза переривання } \\
\text { вагітості }\end{array}$ & 14 & 0 \\
\hline Гестоз & 7 & 0 \\
\hline Анемія під час вагітності & 10 & 5 \\
\hline Кесарський розтин & 3 & 0 \\
\hline Асфріксія першого ступеня & 5 & 0 \\
\hline Пологова травма & 2 & 0 \\
\hline $\begin{array}{l}\text { Передчасні пологи } \\
\text { (недоношеність) }\end{array}$ & 2 & 0 \\
\hline
\end{tabular}

Таблиия 2

Особливості анамнезу дітей першого року життя

\begin{tabular}{|l|c|c|}
\hline \multicolumn{1}{|c|}{ Показник } & $\begin{array}{c}\text { Основна } \\
\text { група (n=20) }\end{array}$ & $\begin{array}{c}\text { Група } \\
\text { порівняння } \\
(\mathbf{n = 1 0 )}\end{array}$ \\
\hline Природне вигодовування & 15 & 10 \\
\hline ГРВІ & 18 & 2 \\
\hline Реакція на вакцинацію & 4 & 0 \\
\hline
\end{tabular}

Таблиия 3

Супутня патологія в досліджуваних дітей

\begin{tabular}{|l|c|c|}
\hline \multicolumn{1}{|c|}{ Показник } & $\begin{array}{c}\text { Основна } \\
\text { група } \\
(\mathbf{n = 2 0 )}\end{array}$ & $\begin{array}{c}\text { Група } \\
\text { порівняння } \\
(\mathbf{n = 1 0 )}\end{array}$ \\
\hline Пренатальна енцефалопатія & 5 & 0 \\
\hline Фебрильні судоми & 1 & 0 \\
\hline Дисплазія кульшових суглобів & 2 & 0 \\
\hline
\end{tabular}

15 (75\%) дітей основної групи знаходились на природному вигодовуванні, а 5 (25\%) - на штучному вигодовуванні з народження. Усі діти групи порівняння знаходились на природному вигодовуванні.

18 (90\%) дітей основної групи на першому році життя хворіли на ГРВІ понад 5-6 разів, майже у всіх перебіг захворювання мав затяжний характер. Тільки у 2 (20\%) дітей порівняльної групи на першому році життя було ГРВI.

Усі діти, як основної, так і групи порівняння, були вакциновані згідно з календарем. У 4 (20\%) дітей основної групи відмічалася реакція на вакцинацію у вигляді підвищення температури до фебрильних цифр протягом 2 днів після вакцинації та місцево поствакцинальний інфільтрат. У дітей групи порівняння не відмічалася реакція на вакцинопрофілактику. Особливості анамнезу дітей першого року життя наведено в таблиці 2.

5 (25\%) обстежуваних дітей основної групи знаходились під наглядом невролога з приводу пренатальної енцефалопатії, а 1 (5\%) дитина мала в анамнезі фебрильні судоми. $2(10 \%)$ дитини основної групи спостерігаються ортопедом із приводу дисплазії кульшових суглобів. У дітей групи порівняння супутньої патології не виявлено (табл. 3).

При оцінці лабораторних даних у дітей основної групи в загальному аналізі крові відмічалося підвищення ШОЕ в межах 15-17 мм/год у 12 (60\%) дітей, лейкоцитоз зі зсувом лейкоцитарної формули вліво - у 10 (50\%) дітей, лімфоцитоз - у 8 (40\%) дітей. Лімфоцитоз спостерігався у дітей основної групи, які мали прояви алергічного або лімфатичного діатезу. Серед дітей групи порівняння лише 1 дитина мала прояви алергічного діатезу. У 3 (15\%) дітей основної групи та в 1 (5\%) дитини групи порівняння діагностувалася анемія першого ступеня. Дані гемограми подано в таблиці 4.

У всіх дітей, як основної, так і групи порівняння, у загальному аналізі сечі зміни не спостерігалися. При 
Дані гемограми обстежуваних дітей

\begin{tabular}{|l|c|c|}
\hline \multicolumn{1}{|c|}{ Показник } & $\begin{array}{c}\text { Основна } \\
\text { група } \\
\text { (n=20) }\end{array}$ & $\begin{array}{c}\text { Група } \\
\text { порівняння } \\
\text { (n=10) }\end{array}$ \\
\hline $\begin{array}{l}\text { Підвищення ШОЕ } \\
(15-17 \text { мм/год) }\end{array}$ & 12 & 0 \\
\hline $\begin{array}{l}\text { Лейкоцитоз зі зсувом } \\
\text { лейкоцитарної формули вліво }\end{array}$ & 10 & 0 \\
\hline Лімфоцитоз & 8 & 0 \\
\hline Анемія першого ступеня & 3 & 1 \\
\hline
\end{tabular}

Дані копрологічного обстеження в спостережуваних дітей

\begin{tabular}{|l|c|c|}
\hline \multicolumn{1}{|c|}{ Показник } & \multicolumn{1}{|c|}{$\begin{array}{c}\text { Основна } \\
\text { група }(\mathbf{n = 2 0 )}\end{array}$} & $\begin{array}{c}\text { Група } \\
\text { порівняння } \\
(\mathbf{n = 1 0 )}\end{array}$ \\
\hline Нестійкі випорожнення & 20 & 2 \\
\hline Наявність слизу & 20 & 0 \\
\hline Поодинокі лейкоцити & 20 & 0 \\
\hline $\begin{array}{l}\text { Неперетравлена } \\
\text { клітковина }\end{array}$ & $\begin{array}{c}20 \text { (у великій } \\
\text { кількості) }\end{array}$ & $\begin{array}{c}2 \text { (у невеликій } \\
\text { кількості) }\end{array}$ \\
\hline $\begin{array}{l}\text { Збільшена кількість } \\
\text { м'язових волокон } \\
\text { та крохмалю }\end{array}$ & 20 & 0 \\
\hline
\end{tabular}

копрологічному дослідженні у всіх дітей основної групи виявлялися такі зміни, як наявність слизу, поодинокі лейкоцити, а також у вигляді значної кількості неперетравленої клітковини, збільшення кількості м'язових волокон і крохмалю. Лише у 2 (10\%) дітей порівняльної групи відмічалися нестійкі випорожнення, а в копрограмі - незначна кількість неперетравленої клітковини (табл. 5).

Усі діти основної групи були оглянуті ЛОР-лікарем у зв'язку зі скаргами батьків на нежить у дитини. 3 боку носоглотки гостра патологія не виявлялася. Лише в 1 (5\%) дитини основної групи відмічалося збільшення аденоїдних вегетацій першого ступеня.

Отже, прорізування зубів у дітей є складним періодом в їхньому житті. Діти з будь-якими проявами нездужання мають бути оглянуті лікарем. Тривалі підвищення температури, нежить, діарея потребують виключення захворювань у дитини [3].

Лікарі та батьки маленьких пацієнтів повинні мати раціональні, а не конфліктуючі поради, тому необхідно підтримувати i заохочувати подальші дослідження з питань прорізування зубів із метою розробки єдиної тактики щодо догляду за немовлятами в цей відповідальний період.

\section{Висновки}

Зазвичай до 1 року дитина має 8 різців, а приблизно до 3 років прорізуються всі 20 молочних зубів. Незначні відхилення від цих термінів не повинні викликати тривогу, оскільки цей процес дуже індивідуальний і залежить від багатьох факторів: характеру харчування матері під час вагітності, якості споживаної води, раціону харчування самої дитини, клімато-географічної зони. Особливу роль відіграє спадковість, оскільки існує генетичний зв'язок між тим, як і коли з'являються зуби в дітей та їхніх найближчих родичів (особливо по лінії матері).

Прорізування зубів є фізіологічним процесом і в більшості дітей не викликає жодних серйозних ускладнень і скарг. Однак у деяких дітей прорізування зубів відображається на самопочутті, що проявляється запаленням ясен, «сверблячим» болем, підвищеним слиновиділенням, порушенням характеру випорожнень. Нерідко підвищується температура тіла, дитина стає примхливою та плаксивою, погано спить. Такі явища переважно спостерігаються в дітей, які мали патологічний перебіг антенатального та інтранатального періодів.

Незначні зміни в загальному аналізі крові (у вигляді підвищення ШОЕ, лейкоцитозу зі зсувом лейкоцитарної формули вліво або лімфоцитозу, анемії першого ступеня) у дітей із синдромом прорізування зубів, імовірніше, пов'язані з особливостями функціонування та становлення імунної системи і кровотворної системи в цей віковий період та особливостями конституції.

Діти з будь-якими скаргами в період прорізування зубів повинні бути оглянуті лікарем для виключення патології та для іiї своєчасного лікування.

\section{ЛIТЕРАТУРА}

1. Богомильский М.Р. Детская оториноларингология / М.Р. Богомильский, В.Р. Чистякова. - М.: ГЭОТАР-Медиа, 2001.

2. Ashley M.P. It's only teething... a report of the myths and modern approaches to teething / M.P. Ashley // BDJ. - 2001. - Vol. 191 (1). P. 4-8.

3. Bennett H.J. The teething virus / H.J. Bennett, D.S. Brudno // Pediatr. Infect. Dis. - 1986. - Vol. 5. - P. 399-401.

4. Bousquet J. Prevention of recurrent respiratory tract infections in children using a ribosomal immunotherapeutic agent. A clinical review / J. Bousquet, A. Fiocchi // Pediatric. Drugs. - 2006. - Vol. 8 (4). P. $235-243$.

5. de Martino M. The child with recurrent respiratory infections: normal or not? / M. de Martino, S. Balloti // Pediatric Allergy and Immunology. 2007. - Vol. 18 (suppl. 18). - P. 13-18, ISSN 0905-6157.

6. FDA Drug Safety Communication: Reports of a rare, but serious and potentially fatal adverse effect with the use of over-the-counter (OTC) benzocaine gels and liquids applied to the gums or mouth. - U.S. FDA (Food and Drug Administration). April 7, 2011.

7. Markman L. Teething: facts and fiction / L. Markman // Pediatr. Rev. 2009. - Vol. 30 (8). - e59-e64.

8. McDonald R.E. Eruption of the teeth: local, systemic and congenital factors that influence the process / R.E. McDonald, D.R. Avery, J.A. Dean // In: Dentistry for the child and adolescent / J.A. Dean, R.E. McDonald, D.R. Avery (Eds). - 9th ed. - St Louis: Mosby, 2010. - P. 155-176.

9. McIntyre G.T. Teething troubles? / G.T. Mclntyre, G.M. McIntyre // BDJ. 2002. - Vol. 192 (5). - P. 251-255.

10. Paediatric homoeopathy in general practice: where, when and why? / S. Ekins-Daukes, P.J. Helms, M.W. Taylor [et al.] // Br. J. Clin. Pharmacol. - 2005. - Vol. 59 (6). - P. 743-749.

11. Swann I.L. Teething complications, a persisting misconception / I.L. Swann // Postgrad Med J. - 1979. - Vol. 55. - P. 24-25. 
12. Symptoms associated with infant teething: a prospective study M.L. Macknin, M. Piedmonte, J. Jacobs, C. Skibinski // Pediatrics. 2000. - Vol. 104. - P. 747-752.

13. Systemic and local teething disturbances: prevalence in a clinic for infants / R.F. Cunha, D.M. Pugliesi, L.D. Garcia [et al.] // J. Dent. Child. - 2004. - Vol. 71. -P. 24-26.

14. Systemic manifestations during eruption of primary teeth in infants / B. Peretz, D. Ram, L. Hermida [et al.] // J. Dent. Child. - 2003. Vol. 70. - P. 170-173.
15. Tighe M. Does a teething child need serious illness excluding? / M. Tighe // Arch. Dis. Child. - 2007. Vol. 92. - P. 266-273.

16. Tsang A.K.L. Teething, teething pain and teething remedies / A.K.L. Tsang // Int. Dent. (Aus. Ed.). - 2010. Vol. 5 (4). - P. 14-28.

17. Wake M. Teething and tooth eruption in infants: a cohort study / M. Wake, K. Hesketh, J. Lucas // Pediatrics. - 2000. - Vol. 106. P. $1374-1378$.

\section{К проблеме прорезывания зубов у детей \\ Л.А. Левадная}

Национальный медицинский университет имени А.А. Богомольца, г. Киев, Украина

цель - определить основные изменения в организме ребенка, которые сопровождают прорезывание молочных зубов.

Пациенты и методы. При обследовании детей использовались данные анамнеза и лабораторная диагностика. Наблюдалось 30 детей в возрасте от 6 месяцев до 2 лет, у которых прорезывались молочные зубы.

Результаты. Установлено, что у большинства детей был выявлен симптомокомплекс прорезывания молочных зубов, который включал повышение температуры тела, послабление стула, насморк. Кроме того, у всех обследованных детей наблюдалось слюнотечение, плаксивость, нарушение сна, беспокойство, снижение аппетита. Данные явления отмечались у детей, которые имели патологическое течение антенатального и интранатального периодов. При оценке лабораторных данных у детей в общем анализе крови выявлялось повышение С0Э в пределах 15-17 мм/час у 12 (60\%) детей, лейкоцитоз со сдвигом лейкоцитарной формулы влево - у 10 (50\%) детей, лимфоцитоз - у 8 (40\%) детей. Эти изменения связанные, больше всего, с особенностями функционирования и становления иммунной системы. Все дети, родители которых обратились относительно жалоб у своих детей на насморк, были осмотрены ЛОР-врачом, который не обнаружил никакой острой патологии со стороны данной системы.

Выводы. Прорезывание зубов является физиологическим процессом и в большинства детей не вызывает никаких серьезных осложнений и жалоб. Дети с любыми жалобами в период прорезывания зубов должны быть осмотрены врачом для исключения патологии и ее своевременного лечения. Ключевые слова: дети, зубы, синдром прорезывания.

\section{PERINATOLOGIYA I PEDIATRIYA.2015.2(62):47-51;doi10.15574/PP.2015.62.47 \\ The problem of teeth eruption \\ L.0. Levadna \\ National Bogomolets O.O. medical university, Kyiv, Ukraine}

Purpose - to reveal changes in the child's organism accompanying the process of milk teeth eruption

Patients and methods. During examining the patients anamnesis data and laboratory diagnostics have been used. 30 children aged from 6 months to 2 years with milk teeth eruption have been included into the investigation.

Results. The complex of milk teeth eruption symptoms including body temperature increase, diarrhoeal manifestations and running nose signs has been estimated in the majority of patients. Salivation, tearfulness, anxiety and appetite disorders have been found out besides. Such manifestations have been mainly marked in children with pathological course of antenatal and intranatal periods. Increased ESR (within 15-17 mm/h) in $12(60 \%)$ patients, leukocytosis with a left shift in $10(50 \%)$ patients and lymphocytosis in $8(40 \%)$ patients have been detected. All these changes are more likely to be connected with the peculiarities of immune system functioning and formation. All the children with a running nose signs have been examined by otolaryngologist who didn't reveal any acute pathology of this system.

Conclusion. Milk teeth eruption is a physiological process and doesn't cause any severe complications and complains. All children with any complaints in the period of milk teeth eruption should be examined by pediatrician for excluding the probable pathology and its timely treatment.

Key words: children, milk teeth, milk teeth eruption syndrome.

Сведения об авторах:

Левадная Людмила Александровна - к.мед.н., доц. каф. педиатрии №1 НМУ им. А.А. Богомольца.

Адрес: г. Киев, ул. М. Коцюбинского, 8а; тел. (044) 465-17-89.

Статья поступила в редакцию 29.04.2015 г. 


\author{
Л.В. Квашніна, В.П. Родіонов
}

\title{
Клінічний досвід використання препарату «Фурасол» (обполіскувач, порошок) виробництва АT "Олайнфарм/JSC "Olainfarm"” (Латвія) в лікуванні загострень хронічного тонзиліту та/або фарингіту в дітей
}

ДУ «Інститут педіатрії, акушерства і гінекології НАМН України», м. Київ, Україна

PERINATOLOGIYA I PEDIATRIYA.2015.2(62):52-55

\begin{abstract}
Мета - підвищити ефективність лікування запальних захворювань рото- та носоглотки (загострень хронічного фраринготонзиліту) в дітей шляхом місцевого застосування препаратів фурагіну розчинного (препарат «Фурасол»).

Пацієнти та методи. Проведено дослідження мікробного спектру носоглотки та загального аналізу крові у 20 дітей різного віку із загостренням хронічного фаринготонзиліту, під впливом локальної монотерапії препаратом фрурагіну розчинного (препарат «Фурасол»).

Результати. Установлено, що загострення хронічного тонзиліту та/або фарингіту у дітей здебільшого викликаються мікробними асоціаціями грамнегативної та грампозитивної мікросрлори. Ерадикації патогенів та нормалізації мікробіоценозу носоглотки сприяє ополіскувач «Фурасол», який, за відсутності побічної, токсичної та алергічної дії, має виражені протимікробні та протизапальні властивості, такі самі або й вищі за властивості антибіотиків in vitro.

Висновки. Зроблено висновки про перспективність застосування фурасолу для профілактики загострень у дітей з хронічною патологією органів зіву та дітей, які часто хворіють, для проведення профілактичних заходів у періоди сезонних спалахів гострих респіраторних вірусних інфекцій.
\end{abstract} Ключові слова: діти, запальні захворювання носоглотки, мікробіоценоз носоглотки, нітрофурани, препарат «Фурасол»

\section{Вступ}

3а даними багатьох дослідників однією з найпоши-

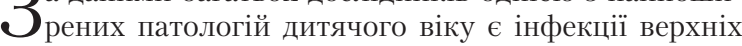
дихальних шляхів, які викликають запалення горла (фарингіт, тонзиліт), гортані (ларингіт) та надгортанника (епіглотит) $[1,2,4,8]$. Провідним симптомом при цьому, як правило, $є$ гострий біль у горлі, з приводу якого хворі звертаються до лікаря. Етіологічним чинником у цих випадках можуть бути як віруси, так і бактеріальна або мікотична флора $[1,8]$. Особливо це стосується хронічного тонзиліту (XТ) (шифр J35 за МКХ-10), поширеність якого в дитячому віці досягає 16,9\% [5]

Відомо, що значна кількість хворих на декомпенсовану форму ХT підлягає оперативному лікуванню, але в постопераційному періоді, як правило, у них розвивається компенсаторний хронічний фарингіт, загострення якого теж потребує лікування. Така структура захворюваності обмежує застосування антибіотиків при захворюваннях горла, з точки зору на можливість розвитку мультирезистентних бактеріальних штамів.

Альтернативою системній антибіотикотерапії захворювань рото- та носоглотки є місцеве лікування антисептиками. Стандартна антисептична терапія базується на використанні препаратів із широким антибактеріальним спектром, які доступні у вигляді спреїв, пастилок для розсмоктування або розчинів для полоскання горла. Серед таких препаратів в останні роки інтерес викликає відомий у клінічній практиці фурагін розчинний, який поєднує широкий спектр антибактеріальної дії з імуномодулюючими властивостями, що доведено науковими дослідженнями $[5,7,9]$. Сучасною формою цього препарату є препарат «Фурасол», антисептичні властивості якого характеризуються низьким ступенем розвитку резистентності мікрофлори до препарату при високому ступені бактерицидної дії. Антибактеріальна дія фурасолу відбувається шляхом пригнічення ензимних систем бактеріальної флори. Крім того, «Фурасол» поліпшує фагоцитоз та лейкопоез, покращує імунний статус організму порівняно 3 іншими нітрофуранами [9]. За необхідності використання антибіотиків, «Фурасол» проявляє виражений синергізм із ними [9]. Застосування фурасолу на слизових оболонках не викликає подразнення або болю, що робить препарат привабливим для лікування дітей. Водночас, щодо застосування препарату в педіатрії обмаль наукових робіт. Такі властивості препарату спонукали нас до вивчення можливостей застосування фурасолу в лікуванні патології рото- та носоглотки в дітей різного віку.

Мета роботи - підвищити ефективність лікування запальних захворювань рото- і носоглотки (загострень хронічного тонзиліту, фарингіту) та рівня дитячого здоров'я шляхом місцевого застосування препаратів фурагіну розчинного (препарат «Фурасол»).

\section{Матеріали та методи дослідження}

Під клінічним спостереженням перебувало 36 дітей у віці 6-14 років, в яких діагностували хронічний тонзиліт (компенсовану або субкомпенсовану форми, які не потребують оперативного втручання) або фарингіт. На момент дослідження всі діти мали стадію загострення хвороби (гіперемію мигдаликів, лакунарний вміст гнійного характеру, гіперплазію лімфоїдної тканини задньої стінки глотки, регіонарний лімфаденіт, підвищення температури, погане самопочуття).

Усім дітям до та після лікування, крім клінічного огляду та розгорнутого загального аналізу крові, проводили ультразвукове дослідження регіонарних лімфовузлів і вивчення мікробного пейзажу носоглотки, для чого вміст мазка з поверхні мигдаликів та порожнини носоглотки сіяли на кров'яний агар, жовтково-сольовий бульйон, середовища Сабуро та Ендо. За відсутності первинного росту, через 6 діб робили пересів на цукровий бульйон, звідки, через 24 години, робили мазки, які фарбували за Грамом і вивчали під мікроскопом з імерсією.

Вивчення чутливості виділеної з зіву флори до антибіотиків проводили за допомогою специфічних дисків, у т.ч. $з$ фурасолом, навантаженням 300 мкг/диск.

Лікування проводили, згідно з інструкцією виробника, шляхом полоскання розчином фурасолу, приготовленим ex tempore, 3-4 рази на добу (залежно від віку дитини), протягом трьох діб. У подальшому діти знаходились під наглядом педіатра протягом 30 діб.

Статистичну обробку отриманих результатів досліджень здійснювали за допомогою стандартних комп'ютерних пакетів програми STATISTICA для Windows. 
Зміни мікробно-вірусного пейзажу верхніх відділів дихальних шляхів у дітей із загостренням хронічного тонзилофарингіту під впливом препарату “Фурасол» (\%)

\begin{tabular}{|l|c|c|}
\hline \multicolumn{1}{|c|}{ Мікрофлора } & Група дітей із загостренням хронічного тонзиліту та/або фарингіту(n=36) \\
\cline { 2 - 3 } & до корекції & \multicolumn{2}{c|}{ під впливом фурасолу } \\
\hline S. epiderm. & $20,2 \pm 1,0$ & $19,0 \pm 1,0$ \\
\hline Str. viridans & $60,8 \pm 1,9$ & $3^{*}, 1 \pm 0.5^{*}$ \\
\hline Str. agalact. & $9,4 \pm 2,2$ & $0^{*}$ \\
\hline K. pneum. & $11,6 \pm 1,8$ & $7,3 \pm 2,0$ \\
\hline S. aureus & $42,9 \pm 1,7$ & $23,0 \pm 4,0^{*}$ \\
\hline Str. faecium & $9,0 \pm 1,1$ & $8^{*}, 0 \pm 1,8$ \\
\hline Str. pyogenes & $11,6 \pm 1,4$ & $6^{*}, 9 \pm 1,2^{*}$ \\
\hline Moraxella catarhalis & $38,0 \pm 2,0$ & $0^{*}$ \\
\hline Candida & $40,1 \pm 1,5$ & $23,2 \pm 2,2^{*}$ \\
\hline
\end{tabular}

Примітка: * - різниця достовірна між показниками до та після прийому препарату $(\mathrm{p}<0,05)$.

\section{Результати дослідження та їх обговорення}

Як показали раніше проведені нами дослідження, верхні відділи дихальних шляхів навіть здорових дітей несуть високе мікробно-вірусне навантаження, яке не має тенденції до самосанації [2, 3]. Під час загострення хронічного тонзиліту (фарингіту) в групі обстежених дітей ситуація значно погіршується за рахунок патогенної флори.

Як видно з таблиці 1, в обстежених дітей до лікування частіше (60,8\%) зустрічався Str. viridans. На другому місці був золотистий стафілокок $S$. aureus (42,9\%), на третьому Candida (40,1\%) та Moraxella catarhalis (38,0\%). Значно рідше в мазках із зіву виявлялися Str. faecium і K. pneum. У значної кількості (48\%) пацієнтів спостерігалася комбінація мікроорганізмів. Найчастіше (39\%) це було сполучення $S$. aureus та Str. viridians. Значно рідшим $(9,0 \%)$ було сполучення асоціації цих мікробів із Moraxella catarhalis.

Відомо, що різні види стрепто-, стафілококів, лактобактерій та гриби роду Candida типові для нормального складу мікрофлори рото- та носоглотки $[3,5,8]$. Проте при ослабленні локального або загального імунітету вони можуть бути чинником інфекційних захворювань. Особливо це стосується таких представників мікробного пейзажу, як Str. viridans, S. aureus, Str. pyogenes, K. pneum. тощо. Якщо носійство сапрофітної, умовно-патогенної або патогенної мікрофлори в організмі дитини без клінічних проявів інфекції не викликає імунної відповіді, то персистенція вірусного або мікробного агента завжди носить характер імунокомпрометованого статусу та потребує формування імунологічної толерантності $[3,9]$. Причому виникає не лише загальний імунологічний дисбаланс, але й імунодефіцит місцевого імунітету. У більшості обстежених нами дітей спостерігалися асоційовані форми бактеріальної контамінації носоглотки плазмо-гемокоагулюючими стафілококами, грибами роду Candida та стрептококами, що засвідчило активну колонізацію органів зіву обстежених дітей патогенними мікроорганізмами i, безумовно, потребувало санації.

Вивчення чутливості виділеної із зіву флори до антибіотиків за допомогою специфічних дисків, у т.ч. з фурасолом, навантаженням 300 мкг/диск (рис.), показало практично стовідсоткову чутливість найбільш типових патогенів до препарату «Фурасол», тоді як чутливість до антибіотиків пеніцилінової та, навіть, цефалоспоринової групи була нижчою. Цей факт можна пояснити тим, що за останні роки безконтрольне застосування антибіотиків привело до формування числених антибіотикорезистентних штамів. Водночас, препарати нітрофуранового ряду застосовувались значно рідше, ніж у минулому.

Після застосування препарату «Фурасол» в якості лікувального заходу відмічалася нормалізація спектру мікрофлори, яка контамінувала носоглотку обстежених дітей. Причому зміни відбулися як в якісному складі мікробів, так і в їх кількості. Під впливом фурасолу частота виявлення асоціацій умовно-патогенних бактерій знизилась 3 48\% до 14\%. Зменшилась кількість дітей, які мали в носоглотці $S$. aureus (з $42 \%$ до $23 \%$ ), гриби роду Candida (з 40\% до 23\%), Str. viridians (з 60\% до 31\%).

У клінічній картині перебігу хвороби в обстежених дітей спостерігалися зниження лихоманки до субфебрильних цифр або нормалізація температури на 2-3-й день лікування, зникнення болю при ковтанні та гіперемії зіву, поліпшення самопочуття. Спостерігаючи за цією групою дітей протягом 30 діб, ми відмітили зменшення роз-

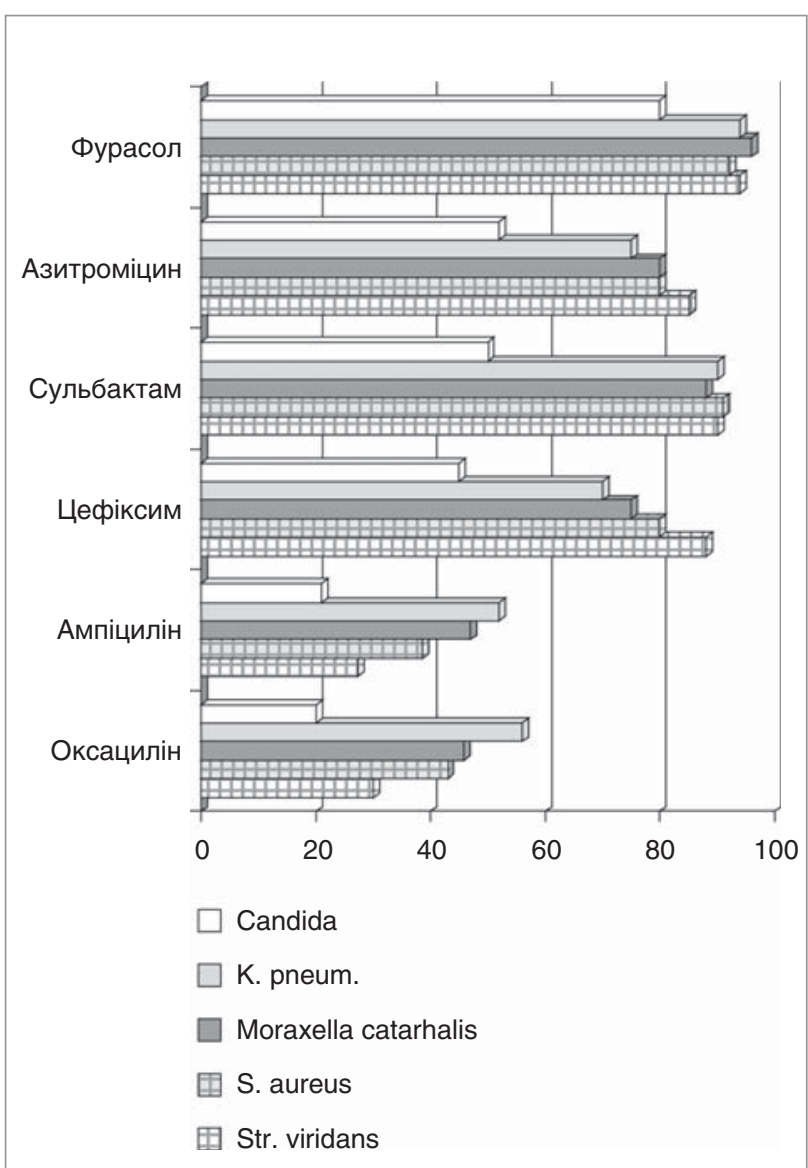

Pис. Чутливість in vitro мікробіоти носоглотки в дітей до антибіотиків та препарату «Фурасол» $(\%)$ 
Загальний аналіз крові в дітей із загостренням хронічного тонзилофарингіту під впливом препарату “Фурасол"

\begin{tabular}{|c|c|c|}
\hline \multirow{2}{*}{ Гемограма } & \multicolumn{2}{|c|}{ Група дітей (n=36) } \\
\hline & до корекції & під впливом фурасолу \\
\hline Гемоглобін, г/л & $125,6 \pm 2,27$ & $126,00 \pm 1,63$ \\
\hline Еритроцити, $10^{12 / \pi}$ & $4,05 \pm 0,06$ & $4,20 \pm 0,04$ \\
\hline Кольоровий показник & $0,93 \pm 0,01$ & $0,93 \pm 0,01$ \\
\hline Лейкоцити, $10^{9 / \pi}$ & $8,93 \pm 0,32$ & $6,00 \pm 0,50^{*}$ \\
\hline ШОЕ, мм/год. & $18,64 \pm 0,65$ & $9,42 \pm 0,55^{*}$ \\
\hline Тромбоцити, $10^{9 / \pi}$ & $264,27 \pm 8,66$ & $260,87 \pm 20,87$ \\
\hline Еозинофіли, \% & $2,27 \pm 0,44$ & $2,73 \pm 0,98^{*}$ \\
\hline Паличкоядерні нейтрофіли, \% & $6,21 \pm 0,44$ & $2,00 \pm 0,01^{*}$ \\
\hline Сегментоядерні нейтрофіли, \% & $62,55 \pm 1,42$ & $45,50 \pm 0,86^{*}$ \\
\hline Лімфоцити, \% & $43,82 \pm 1,31$ & $43,00 \pm 1,08$ \\
\hline Моноцити, \% & $3,09 \pm 0,48$ & $3,70 \pm 0,48$ \\
\hline
\end{tabular}

Примітка: * - різниця достовірна між показниками до та після прийому препарату $(\mathrm{p}<0,05)$.

мірів лімфатичних вузлів (передньо-задньошийних та підщелепних), які нормалізувалися до третього тижня спостережень. Слід відмітити, що в жодному випадку в дітей не було рецидивів захворювання або інтеркурентних хвороб, що, на нашу думку, дає змогу рекомендувати «Фурасол» для профілактики захворювань органів носоглотки в епідемічні періоди. Оцінюючи ефективність будь-якого препарату, завжди викликають інтерес механізми його дії, як прямі, так і опосередковані.

Під впливом фурасолу спостерігалися зміни в обстежених дітей у загальному аналізі капілярної крові (табл. 2).

Як видно з таблиці 2, у дітей, які полоскали зів препаратом «Фурасол», достовірно знизилися показники загального лейкоцитозу зі зсувом уліво, показник ШОЕ та кількість паличкоядерних нейтрофілів, що свідчить про зменшення запального процесу аж до його ліквідації. Така направленість дії фурасолу, на нашу думку, пов'язана зі зменшенням мікробно-вірусного навантаження на дитячий організм та протизапальними властивостями фурагіну розчинного.

У процесі клінічного спостереження ми в жодному випадку прийому препарату «Фурасол» не виявили будьякої побічної, токсичної або алергічної дії. Іншої патології за час спостереження у всіх дітей також не було.

\section{Висновки}

Запальні захворювання горла в дітей (загострення хронічного тонзиліту та/або фарингіту) здебільшого викликаються мікробними асоціаціями грамнегативної та грампозитивної мікрофлори, що потребує протимікробної терапіï.

Ерадикації патогенів сприяє препарат «Фурасол», який поліпшує мікробіоценоз носоглотки в дітей з патологією органів зіву без застосування антибіотиків.

Чутливість мікрофлори зіву в дітей in vitro до препарату «Фурасол» така сама або і вища за чутливість до антибіотиків пеницилінової, цефалоспоринової та макролідної груп.

За відсутності побічної, токсичної та алергічної дії, «Фурасол» має виражені протимікробні та протизапальні властивості і, в застосованій формі вживання (ополіскувач) та дозах, сприяє не лише нормалізації вищезазначених порушень, але й підвищує резистентність дитячого організму до патогенних чинників.

Застосування фурасолу може бути перспективним для профілактики загострень у дітей з хронічною патологією органів зіву та дітей, які часто хворіють, у періоди ремісії для проведення профілактичних заходів під час сезонних спалахів гострих респіраторних вірусних інфекцій.

\section{ЛIТЕРАТУРА}

1. Антипкін Ю.Г. Сучасні погляди на етіопатогенез, клініко-діагностичні та лікувально-профілактичні особливості перебігу запального процесу при неспецифічних захворюваннях органів дихання у дітей / Ю.Г. Антипкін, Т.Г. Надточій // Перинатология и педиатрия. 2011. - № 1 (45). - С. 18-23.

2. Імунорезистентність та мікробний пейзаж носоглотки як один із критеріїв загальної адаптації у здорових дітей молодшого віку / В.В. Матвійчук, Л.В. Квашніна, В.П. Родіонов [та ін.] // Перинатология и педиатрия. - 2009. - № 1 (37). - С. 58-62.

3. Квашніна Л.В. Імунокорекція негативних впливів мікрофлори носоглотки на імунорезистентність здорових дітей молодшого віку / Л.В. Квашніна, В.П. Родіонов, В.В. Матвійчук // Перинатология и педиатрия. - 2009. - № 3 (39). - С. 74-77.

4. Крючко Т.А. Проблема тонзиллита в педиатрической практике / Т.А. Крючко, О.Я. Ткаченко, Т.В. Шпехт // Здоровье ребенка. 2010. - № 1 (22). - С. 79-82.
5. Лайко А.А. Дитяча оториноларингологія / А.А. Лайко. Київ: Логос, 2004. - 899 с.

6. Мельников О. Современные подходы к консервативной терапии хронического тонзиллита / О. Мельников, Д. Заболотная. Київ: ООО «Вістка», 2012. - 36 с.

7. Порівняння ефективності препаратів місцевої дії в лікуванні гострого фарингіту у дітей / Н.А. Бєлих, Н.А. Плугатаренко, І.В. Губіна, В.В. Головін // Перинатология и педиатрия. - 2013. № 1 (53). - С. 49-53.

8. Юлиш Е. И. Хронический тонзиллит у детей / Е. И. Юлиш // Здоровье ребенка. - 2009. - № 6. - С. 26-28.

9. Яшан А.И. Влияние лечения препаратом «Фурасол» на соотношение субпопуляций лимфоцитов периферической крови и нёбных миндалин, эффективность его применения при хроническом тонзиллите / А.И. Яшан, М.И. Герасимюк, Н.И. Красий // Оториноларингология (Восточная Европа). - 2014. - № 3 (16). -С. 2-11. 


\author{
Клинический опыт применения препарата «Фурасол» (ополаскиватель, порошок) \\ производства AO “Олайнфарм/JSC "Olainfarm" (Латвия) в лечении обострений хронического тонзиллита \\ и/или фарингита у детей
}

Л.в. Квашнина, В.П. Родионов

ГУ «Институт педиатрии, акушерства и гинекологии НАМН Украины», г. Киев, Украина

Цель - повысить эффективность лечения воспалительных заболеваний носоглотки (обострений хронического фаринготонзиллита) у детей путем местного применения препаратов фурагина растворимого (препарат «Фурасол»).

Пациенты и методы. Проведено исследование микробного спектра носоглотки и общего анализа крови у 20 детей разного возраста с обострением хронического фраринготонзиллита, под действием локальной монотерапии препаратом фурагина растворимого (препарат «Фурасол»).

Результаты. Установлено, что обострения хронического тонзиллита и/или фарингита у детей чаще всего вызываются микробными ассоциациями грамотрицательной и грамположительной микросрлоры. Эрадикации патогенов и нормализации микробиоценоза носоглотки способствует препарат «Фурасол», который, при отсутствии побочного, токсического и алергизирующего действия, имеет выраженные противомикробные и противовоспалительные свойства, сопоставимые или превышающие in vitro действие антибиотиков.

Выводы. Сделаны выводы относительно перспективности применения фурасола для профилактики обострений у детей с хронической патологией органов зева и часто болеющих детей для проведения профилактических мероприятий в периоды сезонных вспышек острого респираторного вирусного заболевания.

Ключевые слова: дети, воспалительные заболевания носоглотки, микробиоценоз носоглотки, нитрофураны, препарат «Фурасол».

PERINATOLOGIYA I PEDIATRIYA.2015.2(62):52-55

The clinical experience with the drug «Furasol» (powder for solution for rinsing) production of JSC «Olainfarm / JSC "Olainfarm" (Latvia) in the treatment of exacerbations of chronic tonsillitis and / or pharyngitis in children L.V. Kvashnina, V.P. Rodionov

SI «Institute of Pediatrics, Gynecology and Obstetrics NAMS of Ukraine», Kyiv, Ukraine

Purpose - to improve the effectiveness of the treatment of inflammatory diseases of the nasopharynx (exacerbations of chronic faringotonzillita) in children by topical medications furagin soluble (drug «Furasol»).

Patients and methods. A study of the microbial spectrum of the nasopharynx and the general analysis of blood from 20 children of different ages, with exacerbation of chronic faringotonzillita, under the influence of local monotherapy furagin soluble (drug «Furasol»).

Results. It was found that the aggravation of chronic tonsillitis and / or pharyngitis in children is most often caused by microbial associations Gram-negative and Gram-positive microorganisms. Eradication of pathogens and contributes to normalization microbiocenosis nasal drug «Furasol» which, in the absence of collateral, toxic and alergiziruyuschego action has expressed anti-microbial and anti-inflammatory properties comparable to or exceeding the in vitro effect of antibiotics.

The conclusions regarding the prospects for the use of furasola prevention of exacerbations in children with chronic pathology of throat and sickly children to carry out preventive measures during seasonal outbreaks of SARS.

Key words: children, inflammatory diseases of the nasopharynx, nasal microbiocenosis, nitrofurans, the drug «Furasol».

\title{
Сведения об авторах:
}

Квашнина Людмила Викторовна - д.мед.н., проф., зав. отделением медицинских проблем здорового ребенка и преморбидных состояний ГУ «ИПАГ НАМН Украины». Адрес: г. Киев, ул. Майбороды, 8, тел. (044) 483-90-56.

Родионов Владимир Петрович - к.мед.н., вед. науч. сотр. отделения медицинских проблем здорового ребенка и преморбидных состояний ГУ «ИПАГ НАМН Украины». Адрес: г. Киев, ул. Майбороды, 8, тел. (044) 483-80-67.

Статья поступила в редакцию 14.05.2015 г. 


\title{
О.П. Сорочан, І.О. Вороньжев, І.О. Крамний Променеві та морфоклінічні аспекти діагностики пневмоній та їх ускладнень у новонароджених з малою масою тіла (огляд літератури)
}

\author{
Харківська медична академія післядипломної освіти, м Харків, Україна
}

\author{
PERINATOLOGIYA I PEDIATRIYA.2015.2(62):56-61;doi10.15574/PP.2015.62.56
}

\begin{abstract}
Резюме. В огляді літератури наведені сучасні погляди на проблему гострих запальних захворювань легень у новонароджених, особливо в дітей 3 екстремально низькою масою тіла. Детально викладені питання епідеміології гострих запальних захворювань (особливо пневмоній та їх ускладнень) у новонароджених дітей з екстремально малою масою тіла, особливості патоморфології даного ряду захворювань, найхарактерніші клінічні ознаки у цього контингенту хворих з даними лабораторно-інструментальних методів, а також всебічно висвітлені проблеми діагностики цих захворювань за допомогою променевих методів, таких як: рентгенографія, комп'ютерна томографрія, ультразвукова діагностика. Викладені питання диференційної діагностики.
\end{abstract}

Ключові слова: рентгенографія, новонароджені з екстремально малою масою тіла, запальні захворювання легенів.

\section{Вступ}

$\mathrm{O}$ танніми роками проблема гострих запальних захворювань у новонароджених широко вивчається загалом дитячих лікарів усього світу. До запальних захворювань легень у новонароджених відносяться: пневмонії (специфічні, неспецифічні), бронхіт (гострий, обструктивний), бронхіоліт. Із цього переліку найтяжчою та найнебезпечнішою є пневмонія. 3 01.01.2007 р. Україна перейшла на критерії реєстрації перинатального періоду відповідно до рекомендацій ВООЗ, зокрема, передчасні пологи реєструються з повних 22 тижнів вагітності, новонароджена дитина з 500 г маси тіла при народженні [19]. Із того ж часу почала формуватися законодавча база щодо тактики ведення та аспектів виходжування цих дітей.

Слід зазначити, що рівень захворюваності дітей цієі категорії перевищує в 3 рази такий серед новонароджених 3 масою тіла при народженні $\geq 2500$ г, тому що саме діти 3 малою масою тіла при народженні мають підвищений ризик порушення адаптації та розвитку патологічних станів [14]. Захворюваність контингенту дітей, що народилися з масою 500-1500 г, своєю чергою, в багато разів вища, ніж у новонароджених 3 масою 1500-2500 г. Слід констатувати, що на сьогоднішній день визначається позитивна динаміка серед виживання контингенту народжених з дуже малою та екстремально малою масою тіла, але ці рівні, на жаль, досить низькі [26].

Запальні захворювання легень входять до п'яти основних причин захворюваності і смертності цих дітей, що обумовлюється не лише самим запальним процесом, а переважно появою ускладнень. Найбільш значущими з них є:

I. Легеневі ускладнення: гостра дихальна недостатність; ексудативний плеврит та/або емпієма плеври; абсцес легень.

II. Позалегеневі ускладнення: інфекційно-токсичний шок; сепсис [16].

Не останню роль відіграє стан здоров'я матерів та їній вік. Серед жінок у пізньому дітородному віці недоношені діти зустрічаються на $11 \%$ частіше, але вік не відіграє значної ролі в частоті їх захворюваності на запальні процеси легень. Також процент недоношених залежить від супутньої патології [17, 27].

Відповідно до МКХ-10 виділяють:

P07 - Розлади, пов'язані з вкороченням терміну вагітності і малою масою тіла при народженні, що не класифікуються в інших рубриках.

Р07.0 - Екстремально мала маса тіла при народженні $(<999$ г).

Р07.1 - Інші випадки малої маси тіла при народженні $(1000-2499$ г).
Р07.2 - Крайня незрілість (термін вагітності менше 28 повних тижнів або менше 196 плодових днів).

Епідеміологія. У багатьох країнах світу ця проблема досліджується впродовж багатьох років. Україна в цьому питанні ще не має великого досвіду, але рухається в цьому напрямку [9]. Питома вага передчасних пологів в Україні становить близько 5\%. Водночас, 10-12\% новонароджених в Україні мають масу тіла при народженні <2500,0 г [18]. Так, якщо у 2007 р. в Україні народилося живими 2270 новонароджених з масою тіла 500-1499 г (0,48\%), з них 915 малюків з масою тіла 500-999 г, то у 2010 р. таких дітей народилося 3616 (0,73\%), з них 1141 дитина з масою тіла 500-999 г та 23 дитини з масою тіла $<500$ г [9, 14].

Для прикладу: у 2011 р. в Пермському краї Російської Федерації зареєстровано такі дані - народилося 36099 дітей, з них 1975 (5,5\%) недоношених, серед недоношених 227 (11,5\%) народилися 3 дуже низькою масою тіла, 95 (4,8\%) - з екстремально низькою масою тіла [4].

3 літератури відомо, що пневмонія в новонароджених взагалі викликається тими самими збудниками, що i в дорослих: стрептококами групи B, E. coli, коагулазонегативними стафілококами, синьогнійною паличкою, ентерококами, різними вірусами, пневмоцистами, хламідіями, мікоплазмою, цитомегаловірусом, грибковою флорою та ін. [8, 15].

Щодо поширеності пневмоній серед новонароджених дітей у вітчизняній літературі дуже мало даних. Частота пневмоній у новонароджених в Росії становить 1,0-1,5\% для доношених і 10-15\% для недоношених [7]. На розтині у мертвонароджених пневмонії виявлялися у 15-38\%, у тих, що народилися живими і померли в ранньому неонатальному періоді, - у 20-32\% [32]. Також є дані лише по окремих формах пневмонії: так, наприклад, частота цитомегаловірусної пневмонії зареєстрована в 2-10\% серед усіх інфікованих цитомегаловірусом (ЦМВ), і це становило 13,8\% усіх пневмоній при розтинах дітей, померлих до 1 року [25].

Патоморфологія. Патоморфологічні зміни при пневмонії в новонароджених дітей більш виражені, ніж у дітей інших вікових груп. Уся тканина легені реагує дифузним судинним набряком i набряком альвеол незалежно від розмірів пневмонічного вогнища, що $€$ наслідком підвищеної проникності судинної стінки. Ексудат в альвеолах зазвичай не містить слизу, а складається із серозної рідини з великою кількістю лейкоцитів і змертвілих клітин альвеолярного епітелію. При великій кількості останнього пневмонія приймає форму так званої десквамативної, описаної у свій час Булем [29].

Для вогнищевих пневмоній раннього дитячого віку досить характерний серозно-геморагічний ексудат зі 
значною кількістю лімфоїдних клітин. Також особливістю пневмонії новонароджених, здебільшого недоношених, $€$ залучення в процес інтерстиціальної тканини, що приводить до потовщення альвеолярних перегородок у результаті інфільтрації фібробластами і макрофагами [29]. Макроскопічно легеня при бронхопневмонії може виглядати по-різному, залежно від характеру основного процесу - дрібно-вогнищевого, великовогнищевого або зливного. Поряд із дрібними і великими вогнищами бронхопневмонії, які виступають над поверхнею розрізу легені у вигляді зернистих утворень сірувато-червоного і сірувато-жовтого кольору (у більш пізній стадіï), є і темні синювато-червоні ділянки тканини, яка спалася (ателектази). Мікроскопічно виявляються обмежені вогнища некрозу різного розміру і форми [23].

Зазвичай, як при внутрішньоутробній пневмонії, так і при тій, що виникла після народження, на поверхні розтину легені виявляються здебільшого симетрично розташовані вогнища круглої або овальної форми. Навколо них визначається безповітряна темно-червона легенева тканина. Усі ці зміни надають вид «строкатої» або «мармурової» легені [40]. Патоморфологічні зміни при ЦМВ-пневмонії подібні вищевикладеним, і після розвитку інтерстиціальної пневмонії приєднується дифузний персистувальний альвеоліт, що в подальшому призводить до масивного фіброзу. При пневмоцистній пневмонії внутрішньоклітинний паразит викликає масивну інфільтрацію стінок альвеол плазматичними клітинами. Унаслідок цього стінки альвеол стовщуються у 10-20 разів, утворюється альвеолярно-капілярний блок, що призводить до тяжкої дихальної недостатності. Колібацилярна пневмонія перебігає зазвичай, як дрібновогнищева або зливна, можливе утворення булл, абсцесів, некрозів легеневої тканини. Також важливою рисою пневмонії в дітей є тенденція до поширення процесу, навіть через міжчасткову плевру, з причини ії недорозвинення.

Клінічна картина. У зв'язку з тим, що пневмонії новонароджених можуть викликатися різними збудниками, їх клінічна картина може дещо різниться. Для дітей 3 масою тіла $<1000$ г серед збудників перше місце посідають стрептококи групи В із такими клінічними проявами: лихоманка або гіпотермія, артеріальна гіпотонія, здуття живота, блідість шкіри і слизових оболонок, летаргія 3 перших хвилин життя. При будь-яких варіантах розвитку зазвичай має місце тахіпное, напади апное, шумне дихання, блідість або ціаноз. За даними літератури, летальність при ранньому початку стрептококової В-інфекції становить $20-55 \%$ [23, 28].

Перебіг пневмонії в більшості новонароджених має свої особливості, до яких відносяться: домінування загальних симптомів, дихальної недостатності й токсикозу; вираженість гіпоксемії і гіперкапнії; змішаного респіраторно-метаболічного ацидозу, які спостерігаються довго, хоча на початку пізніх неонатальних пневмоній внаслідок гіпервентиляції і при супутній діареї, через втрату електролітів, може бути і алкалоз [24].

Для колібацилярних пневмоній типовим є виражений токсикоз із порушеннями центральної нервової системи (ЦНС): неспокій, відригування, блювання, погане смоктання, зниження маси тіла, м'язова гіпертонія, але гіпорефлексія, артеріальна гіпотензія. Шкірні покриви бліді, спостерігається анемія. Температура тіла фебрильна або субфебрильна. Напади ціанозу. Розширення меж відносної серцевої тупості, приглушення тонів серця Велика кількість хрипів у легенях, чіткі перкуторні дані. Прогноз при раціональній терапії частіше сприятливий, але перебіг хвороби дуже тривалий, що потребує тривалої штучної вентиляції легень (ШВЛ), інтенсивної антибіотикотерапії та пасивної імунотерапії.

Пневмонія, обумовлена синьогнійною паличкою, найчастіше є вторинною інфекцією, одним із проявів сепсису. Типові некротичні зміни шкіри, виражені явища інтоксикації з гальмуванням ЦНС - загальмованість, млявість, відригування, блювання, зниження м'язового тонусу і рефлексів, кома. Температура тіла частіше нормальна або субфебрильна, у багатьох дітей розвивається гіпотермія, в крові анемія, лейкопенія, нормальна або помірно прискорена ШОЕ. Пневмонія зазвичай деструктивна 3 великою кількістю дрібних абсцесів, виділенням великої кількості слизово-гнійного або гнійного мокротиння зеленуватого кольору зі специфічним запахом. Часті геморагічні явища, не завжди обумовлені ДВС-синдромом. Прогноз для життя частіше несприятливий [39].

Вірусні пневмонії також є достатньо частою патологією в новонароджених і дітей раннього віку. Так, наприклад, серед досліджених дітей в одному з дитячих шпиталів [3] вірусна пневмонія спостерігалася майже в половині випадків запальних захворювань легень, 3 яких найчастішою була гостра пневмонія, викликана аденовірусом. За даними деяких авторів [14], у дітей респіраторно-синцитіальний вірус посідає перше місце серед вірусних збудників пневмоній.

Не слід забувати про особливості перебігу пневмоній на фоні зниженого імунітету, до яких відносяться пневмоцистні, хламідійні, мікоплазмові та цитомегаловірусні. Клінічна картина їх може бути різною і залежить від великої кількості факторів: ступеня зниження імунної відповіді, віку дитини, ступеня зрілості організму, виду збудника і т.д. [42, 43].

При гострій дихальній недостатності, як прояві респіраторного дистрес-синдрому (РДС), у недоношених рано з'являються периорбітальний і периоральний ціаноз, участь допоміжної мускулатури в акті дихання, зневоднення, зменшення маси тіла. Токсикоз і дихальна недостатність у недоношених дуже рідко супроводжуються іритативними змінами; типовими є ознаки пригнічення ЦНС: млявість, адинамія, зниження м'язового тонусу i рефлексів (зокрема, раннє зникнення смоктального і ковтального рефлексу), відригування, блювання, зниження маси тіла. Характерне для них порушення ритму дихання, напади апное, періодичне дихання типу ЧейнСтокса та ін. Лихоманка в недоношених буває не завжди, можлива гіпотермія. Набагато більша частота ускладнень, як легеневих (пневмоторакс, ателектази, плеврит тощо), так і позалегеневих (отит, парез кишечнику, гемодинамічні розлади, декомпенсований ДВС-синдром, геморагічний синдром через тромбоцитопатії та/або тромбоцитопенії, гіпотрофія, склерема, недостатність надниркових залоз, метаболічні порушення). 3 метаболічних порушень у недоношених із пневмоніями реєструються змішаний ацидоз, гіпоглікемія, гіпербілірубінемія, гіпокальціємія, гіпонатріємія, гіпокаліємія. Крім того, у них більша частота появи при пневмонії пінистих виділень із рота внаслідок низької резорбційної здатності легеневої тканини, а також більша частота застійних явищ у легенях (з цієї ж причини в них частіше вислуховуються крепітувальні хрипи при пневмонії) [24, 36].

y недоношених набагато частіше пневмонія ускладнюється синдромом персистуючого фетального кровообігу, а після тривалої ШВЛ - синдромом відкритої артеріальної протоки. 3 іншого боку, у них частіше 
зустрічаються порушення периферичного кровообігу набряковий синдром, периорбітальний і акроціаноз, мармуровий малюнок шкіри, сіруватий іiі колір, похолодіння кистей і стоп [42]. Перенесена пневмонія - сприятливий чинник для розвитку ранньої анемії недоношених та рахіту. У недоношених частіше, ніж у доношених, зустрічаються аспіраційні пневмонії через схильність до відригування. Частою і навіть типовою є послідовність подій: РДС - пневмонія - сепсис, на відміну від доношених, у яких легені виключно рідко є «вхідними воротами» інфекції при сепсисі. Висока частота поєднання пневмонії 3 іншими захворюваннями (з внутрішньочерепними геморагіями, кишковою колі-інфекцією, гемолітичною хворобою новонароджених та ін.). Більша, ніж у доношених, тривалість нестійкого клінічного стану хворих перебігу хвороби, частота віддалених наслідків - бронхолегеневої дисплазії, що призводять до рецидивних бронхолегеневих захворювань [26, 32].

Ексудативний плеврит на початку захворювання проявляється пітливістю вночі, субфебрильною температурою, млявістю. У розпал захворювання з'являються такі симптоми: 1) вимушене положення на ураженому боці; 2) задишка; 3) серцебиття. При об'єктивному обстеженні на боці ураження спостерігається відставання рухів грудної клітки, міжреберні проміжки згладжені. На боці ураження перкуторно відзначається тупість, яка зі збільшенням випоту починає поширюватись вище і у вертикальному положенні утворює дугоподібну лінію лінію Соколова-Дамуазо. Емпієма плеври при об'єктивному обстеженні не має особливих відмінностей. Вона перебігає зі значним підвищенням температури, профузним потовиділенням. Динаміка при ексудативному плевриті син- або метапневмонічної природи становить 14-28 діб, при емпіємі довша і після себе залишає значні зміни у вигляді злук і шварт [24].

Абсцеси легень виникають досить рідко [38], і лише половина з них є вторинними. Характерне їх формування для стафілококових пневмоній, рідше - для синьогнійної інфекції. Розвиваються в дітей зі зниженими імунітетом. Клінічно можна виказати підозру на формування абсцесу при затяжному перебігу пневмонії, наявності лейкоцитозу протягом 1 місяця з переважанням молодих форм. Підтвердити діагноз можна за допомогою рентгенологічного методу [35].

РДС зазвичай передує пневмонії в цих дітей, інколи можлива одночасна поява цих процесів.

Рентгенологічні ознаки. Слід зазначити, що відповідно до рекомендацій [15], кожний випадок пневмонії повинен бути підтверджений рентгенологічно. Виділяють у дітей чотири види пневмоній: вогнищеву, сегментарну, крупозну та інтерстиціальну [19]. Вогнищеві пневмонії у фазу розпалу в доношених дітей характеризуються наявністю одного або декількох осередків запального характеру, розмірами від 0,3-0,5 см до 1,5-2,0 см. 3 нашої точки зору, виділення таких розмірів вогнищевих тіней для недоношених новонароджених є недоцільним, оскільки розмір у 2 см для дитини з екстремально малою масою тіла може мати частка. На жаль, дані про особливості рентгенологічного перебігу пневмоній у дітей 3 ектремально низькою масою тіла у вітчизняній та іноземній літературі практично відсутні, ця проблема є малоабо зовсім не вивченою. Форма вогнищ частіше кругла або овальна, більш інтенсивна в центрі, контури зазвичай нечіткі, легеневий малюнок на цьому фоні не визначається. Процес легко переходить на сусідній сегмент, але, доходячи до міжчасткової плеври, може зупинитися.
При цьому може визначатися потовщення останньої, або навіть спостерігатися невелика кількість плеврального випоту $[3,13,20]$. У дітей до 1 року пневмонічні вогнища локалізуються переважно в задніх, прилеглих до хребта відділах легень (II, VI і Х сегменти) [22].

Деякі автори виділяють також стадії пневмоній у недоношених новонароджених за рентгенологічними даними: 1 ст. (інфільтрації) - затемнення легеневої тканини без чітких контурів і меж, частіше в периферичних відділах сегментів (або обмежене міжсегментарними перегородками); 2 ст. (розсмоктування) - протяжність та інтенсивність інфільтрації зменшується, посилення легеневого малюнка на фоні підвищеної пневматизації тканини легені; 3 ст. (інтерстиціальних змін) - інфільтративні зміни відсутні, виявляються інтерстиціальні зміни у вигляді сітчастої деформації легеневого малюнка [2].

За рентгенологічними даними, частота двобічних пневмоній переважає однобічні і відповідно становить $57,3 \%$ та 42,7\%. До того ж пацієнти 3 двобічним процесом виходять із цього стану набагато повільніше та з більшою кількістю ускладнень (42,9\% проти 19,2\%). За викладеними в літературі проблемами немає єдиної точки зору, деякі автори зазначають, що більш характерними для цих хворих є ділянки здуття легеневої тканини, інші ж стверджують, що для них більш типовою є наявність ателектазів (часткових, або розсіяних), особливо в недоношених новонароджених[1, 21].

ШВЛ-асоційовані пневмонії посідають важливе місце в захворюваності цих дітей, при цьому одні автори зазначають, що осередкові тіні мають місце лише в 5-7\% цих пневмоній, і не можна погодитися з твердженням цих авторів, що пневмонії проявляються деформацією легеневого малюнка та зниженням вентиляції легеневих полів, оскільки головною ознакою пневмонії $є$ наявність інфільтрації. Інші ж дослідники вважають, що рентгенологічна картина не відрізняється від осередкових пневмоній, а різниця полягає лише в тяжкості й тривалості останніх $[3,14]$.

Окремі автори навіть намагаються виділяти характерні симптомокомплекси і проводити порівняння перебігу пневмонії в дітей з різною масою тіла при народженні та наявністю чи відсутністю затримки внутрішньоутробного розвитку (ЗВУР) із РДС. Вони вказують на чітку залежність між подібністю рентгенологічної картини пневмонії в недоношених дітей та різних ступенів РДС. Таким чином, зазначають, що зміни при пневмонії в доношених дітей без ЗВУР подібні до І ступеня РДС, тобто має місце міліарна плямистість, обмежені неоднорідні затемнення низької інтенсивності, слабко виражена повітряна бронхограма. У доношених зі ЗВУР картина схожа на I-II ступінь РДС - зниження пневматизації, грубі ділянки ущільнення легеневої тканини $\mathrm{i}$ «повітряні бронхограми». А в недоношених дітей ознаки нагадували II-III ступені РДС - значне зниження пневматизації, нечіткість легенево-діафрагмальної та легенево-серцевої межі, чіткі «повітряні бронхограми» [21]. Інші ж дослідники вважають за недоцільне проводити порівняння цих станів, тому що доволі часто вони перебігають одночасно, або РДС утруднює діагностику пневмонії в недоношених новонароджених [6, 12].

У деяких працях науковці порівнюють наявність і поширеність рентгенологічних змін легень у трьох групах хворих: недоношені діти з пневмонією, недоношені діти з РДС, недоношені діти з РДС і пневмонією. Цілком логічно, що найбільш поширені ураження легеневої тканини зміни спостерігаються при поєднанні РДС 
та пневмонії, в 2 рази менший обсяг займає ураження при наявності самого лише РДС і в 4 рази менше - при наявності лише пневмонії. Інші автори вважають, що оцінка рентгенологічних змін лише за об'ємом ураження не $є$ показовою і має грунтуватися на комплексі показників [1, 10, 16].

Пневмонія може перебігати і як осередково-зливна. При стафілококових пневмоніях нерідко можуть приєднуватися деструктивні явища, які на рентгенограмах виглядають як ділянки просвітлення. При неускладненому перебігу на фоні антибактеріальної терапії через 3-4 доби інфільтративні явища поступово зникають, а на 7-10-ту добу вже визначається лише посилення легеневого малюнка. При стафілококових пневмоніях перебіг більш тривалий, особливо в дітей з малою масою тіла, і достатньо часто ускладнюється вогнищами деструкції, що рентгенологічно виявляється порожнинами просвітлення на фоні суцільної інфільтрації [12, 22].

Характерні ознаки має хламідійна пневмонія, яка рентгенологічно проявляється наявністю смугастих затемнень по ходу сегментарних бронхів. Інші автори вказують на те, що для неї притаманна емфізема та двобічна дифузна інфільтрація. Але все ж остаточний діагноз підтверджується за допомогою лабораторних досліджень [4, 13].

Пневмоцистна пневмонія (пневмоцистоз) також має свої характерні рентгенологічні особливості у вигляді так званої «ватної легені», тобто наявності великої кількості осередкових тіней, осередків здуття легеневої тканини, корені нечіткі, можливі ателектази [13].

Сегментарна пневмонія являє собою більш поширений процес, що займає декілька сегментів. У патологічний процес залучаються бронхи, на відміну від вогнищевої, при якій уражається лише паренхіма. На рентгенограмі виявляється гомогенне затемнення одного або кількох сегментів, нерідко трикутної форми, межі частіше чіткі і дещо втягнуті (оскільки у новонароджених дуже часто присутній ателектатичний компонент), йдуть по міжсегментарних перегородках. Цей вид пневмонії перебігає більш торпідно і має схильність до фіброзної трансформації з розвитком обмеженого пневмофіброзу. Динаміка більш тривала, перебігає до 2-3 тижнів [11].

Крупозна пневмонія обумовлена частіше пневмококом. Різниця в порівнянні з сегментарною лише за клінічними ознаками. Взагалі крупозна пневмонія характеризується такими ознаками, як вибухання меж осередку інфільтрації, чіткими контурами в межах міжчасткових плевральних листків, значним розширенням кореня на боці ураження. Єдиною рисою, яка спостерігається і в дітей, є ознака Флейшнера (наявність просвітків повітряних бронхів на фоні гомогенної інфільтрації). Усі ці ознаки характерні для дітей старшого віку або для дорослих, а в новонароджених нерідко має місце атипова рентгенологічна картина без характерних особливостей. «Позитивною» рисою є швидка динаміка після призначення антибіотикотерапії і перебіг без ускладнень [12].

Вірусні пневмонії, за даними деяких авторів, завжди починаються як інтерстиціальні, надалі до цих ознак приєднуються вогнищеві тіні, які інколи переходять у великі фокуси, які не відповідають межам часток або сегментів, частіше локалізуються в периферичних відділах. Динаміка тривала $-3-6$ тижнів, спочатку зникають вогнища інфільтрації, легеневий малюнок нормалізується пізніше. Розпад не є характерним, може спостерігатися лише при приєднанні бактеріальної флори [30].

Пневмонії на фоні зниженого імунітету можуть проявлятися по-різному, як різновид будь-якої форми
3 вищеперерахованих, мають тривалий перебіг і яскраву рентгенологічну картину (значна кількість вогнищевих тіней зливного характеру зі схильністю до розпаду), яка не завжди відповідає тяжкості клінічної картини. Слід зазначити, що в таких дітей завжди в тій чи іншій мірі є порушення імунного статусу, тому при проведенні діагностики важливо про це не забувати. Дуже характерний розвиток ускладнень, таких як плеврит, емпієма чи абсцедування [22].

Поява ускладнення пневмонії у вигляді ексудативного плевриту достовірно визначається за допомогою променевих методів діагностики. Рентгенологічно в дитини виявляється кількість рідини 20-30 мл (залежно від віку дитини), а менша кількість може виявлятися за допомогою ультразвукової діагностики (УЗД) або комп'ютерної томографії (КТ). Встановити характер рідини, що знаходиться в плевральній порожнині, майже не можливо. За даними деяких авторів, при емпіємі рідина має більш косий рівень і більшу інтенсивність, але ці показники $є$ відносними і за їх допомогою впевнено підтвердити діагноз не можливо. Абсцеси також достатньо добре виявляються за допомогою рентгенографії, або хоча б їх можна передбачити і далі використовувати більш точні методи [31, 34].

Ультразвукова діагностика теж посідає своє місце в діагностиці здебільшого різних ускладнень, таких як плеврити, емпієми та абсцеси. Ї̈ї перевагою є відсутність променевого навантаження, але, наприклад, у встановленні пневмонії вона не завжди є інформативною, особливо при розташуванні вогнищ далеко від плащової зони. Існують дослідження окремих авторів [37], які переконують у перевазі УЗД над рентгенографією за інформативністю, особливо в дітей, посилаючись на те, що майже завжди вогнища інфільтрації розвиваються в часточці і широкою основою звернені до плеври. За їхніми даними, інформативність становить 93-100\% і навіть інколи пневмонія діагностується тільки на УЗД [5]. Але переважна більшість все ж віддає перевагу рентгенографії [11, 16, 23].

Комп'ютерна томографія на сьогоднішній день $€$ провідним методом серед променевих і в багатьох ситуаціях може допомогти уточнити діагноз. Обстеження цих дітей ускладнене i, за даними [35], близько у половини новонароджених не вдається використати цей метод (або за технічними причинами, або протипоказаннями різного характеру). Обстеження виконується при обов'язковій седації пацієнтів, що в їхньому віці є вкрай небажаним [31]. Ще не слід забувати, що променеве навантаження при цьому методі в 250-3000 разів вище, ніж при звичайній рентгенографії, i, за даними [41], на 1000 онкологічних захворювань у дітей при проведенні КТ індукованих випадків онкопатології у віці до 10 років 2 випадки, у віці до 15 років - 3 випадки.

Проводилися порівняльні дослідження за інформативністю УЗД та КТ у визначенні різних ускладнень пневмонії, і жоден із методів не отримав переваги, даючи приблизно однакові результати [33].

Магнітно-резонансна томографія має свої складнощі в дослідженні легень навіть у дорослих і потребує більш досконалої апаратури, а в новонароджених дітей іï виконання дуже складне. Воно потребує спеціального устаткування (і що є характерним - розмір цього устаткування повинен ідеально підходити пацієнту) і загального наркозу, який для них є дуже шкідливим, особливо з огляду на тяжкий стан цих дітей [7].

\section{Висновки}

Таким чином, променева та клініко-морфологічна діагностика пневмоній та їх ускладнень у новонародже- 
них з малою масою тіла залишається однією з актуальних проблем сучасної медицини. Серед променевих методів досліджень рентгенографія органів грудної клітки все ж залишається методом дослідження першої черги для вия- влення запальних захворювань легень у новонароджених дітей з низькою масою тіла у зв'язку з її великою інформативністю і доступністю, особливо з огляду на той факт, що кількість цих дітей невпинно зростає.

\section{ЛIТЕРАТУРА}

1. Аряев Н.Л. Детская пульмонология / Н.Л. Аряев. - Київ: Здоров'я 2005. -605 c.

2. Волянюк Е.В. Врожденная пневмония у недоношенных новорожденных: особенности этиологии, диагностики и лечения / Е.В. Волянюк, А.И. Сафина // Практическая медицина. - 2011. № 5 (11). - С. 18-22.

3. Волянюк Е.В. ИВЛ-ассоциированная пневмония у недоношенных новорожденных / Е.В. Волянюк, А.И. Сафина, А.Г. Габдулхакова // Практическая медицина. - 2012. - № 7 (12). - С. 1-5.

4. Воротынцева Н.С. Рентгенологическая динамика изменений в легочной ткани у детей с низкой и экстремально низкой массой тела при рождении / Н.С. Воротынцева, С.Г. Воротынцев // Променева діагностика, променева терапія. - 2014. - № 1-2. - С. 53-57.

5. Григорян В.Р. Ультразвуковая диагностика как альтернативный метод исследования заболеваний легких у детей / В.Р. Григорян // Матер. 8 Всероссийского національного конгресса лучевых диагностов и терапевтов «Радиология 2014. - М., 2014. C. 204-205.

6. Зміни органів грудної клітки у новонароджених: пос. / І.О. Вороньжев, І.О. Крамний, О.П. Сорочан, С.В. Лімарєв. - Харків, 2014. - С. 31-56.

7. Значение инструментальных методов диагностики врожденных образований легких в перинатологии / В.О. Панов, Н.И. Кохно, Ю.И. Кучеров, А.И. Волобуев // Радиология практика. - 2006. - № 4. - С. 6-15.

8. Информационный бюллютень. - 2013. - № 331. - Режим доступа http://www.who.int/mediacentre/factsheets/fs331/ru. Название с экрана.

9. Катамнез детей, рожденных с очень низкой и экстремально низкой массой тела / Н.Б. Мерзлова, Ю.В. Курносов, Л.Н. Винокурова, В.И. Батурин // Современная перинатология: организация, технологии и качество: Материалы I Междунар. Конгр. по перинат. Мед. и VI Ежегодного Конгресса специалистов перинатальной медицины. - М., 2011. - С. 10.

10. Клименко Т.М. Внутриутробные пневмонии у недоношенных новорожденных: ранняя и дифференциальная диагностика / Т.М. Клименко, Л.А.Левченко // Неонатологія, хірургія та перинатальна медицина. - 2011. - № 2 (т. 1). - С. 25-30.

11. Крамний І.О. Рентгенологічна характеристика змін легень при гострих бронхолегеневих захворювань у немовлят / І.О. Крамний, І.О. Вороньжев, І.С. Лобода // Український радіолог. журнал. 2007. - № 3. - С. 257-259.

12. Крамной И.Е. Рентгенологическая характеристика острых пневмоний и их осложнений у новорожденных / И.Е. Крамной, И.А. Вороньжев, В.Ю. Гребенюк // Проблеми мед. науки та освіти. - 2010. - № 4. - С. 39-40.

13. Кривопустов С.П. Пневмония новорожденных: особенности диагностики и лечения / С.П. Кривопустов // Здоров'я України. 2008. - № 18/1. - С. 32-33.

14. Моніторинг стану здоров'я матері та дитини: аналіт. стат. довідн. на колегію МОЗ України за 2007 рік / МОЗ України, Центр медичної статистики; гол. ред. В.М. Князевич. - Київ, 2008. - 35 с.

15. Моніторинг стану здоров'я матері та дитини MATRIX - BABIES: аналіт.-стат. дов. / МОЗ України, ДЗ Центр медичної статистики; гол. ред. О. В. Аніщенко. — Київ, 2011. - 48 с.
16. Педіатрична рентгенологія: керівництво / М.І. Спузяк, І.О. Крамний, О.П. Шармазанова [та ін.]; за заг. ред. проф. М.І. Спузяка і доц. І.О. Крамного. - Т. 1. - Харків: Цифрова друкарня № 1, 2013. - С. 59-105.

17. Про затвердження клінічного протоколу з Первинної реанімаційної допомоги новонародженим: наказ МОЗ України від 08.06.2007 p. № 312 [Електронний документ]. - Режим доступу: http://www.moz.gov.ua. - Назва з екрана.

18. Про затвердження клінічного протоколу надання допомоги новонародженій дитині 3 дихальними розладами: наказ МОЗ України від 21.08.2008 р. № 484 [Електронний документ] Режим доступу: http://www.moz.gov.ua. - Назва з екрана.

19. Про затвердження протоколу медичного догляду за новонародженою дитиною з малою масою тіла при народженні: наказ МОЗ України від 29.08.2006 р. № 584 [Електронний документ]. Режим доступу: http://www.moz.gov.ua. - Назва з екрана.

20. Рентгенодіагностика гострих захворювань органів дихання у дітей / М.О. Бортний, І.О. Вороньжев, І.О. Крамний, Р.Ю. Чурилін; за ред. І.О. Крамного. - Харків: Крокус, 2006. - 172 с.

21. Рентгенологические варианты развития пневмонии у недоношенных детей / М.Н. Абдуллаева, Г.М. Мардыева, М.Ю. Ашурова [и др.] // Матер. IV Всероссийского Национального Конгресса лучевых диагностов и терапевтов «Радиология 2010». - М., 2010. - С. 7.

22. Спузяк М.І. Рентгенодіагностика захворювань органів дихання у новонароджених / М.І. Спузяк, І.О. Крамний, І.О. Вороньжев // Радіологічний вісник. - 2009. - № 3 (32). - С. 18-29.

23. Струков А.И. Патологическая анатомия: учебник / А.И. Струков, В.В. Серов. - М.: Медицина, 1995. - С. 567-580.

24. Шабалов Н.П. Неонатология: учебное пос. / Н.П. Шабалов. М.: МЕДпресс-информ, 2004. - Т. 1, 2. - С. 507-583.

25. Шахгильдян В.И. Клинико-лабораторная характеристика, патоморфологические особенности, диагностика и лечение цитомегаловирусной пневмонии / В. И. Шахгильдян, О.А.Тишкевич, О. Ю. Шипулина // Инфекционные болезни. - 2008. - Т. 2, № 1. C. $73-80$.

26. Шунько Є.Є. Діти з дуже малою масою тіла: сучасні проблеми організації медичної допомоги, інтенсивної терапії та виходжування / Є.Є. Шунько, О.С. Яблонь // Жіночий лікар. - 2007. - № 4. - С. 7-13.

27. Яворський П.В. Оптимізація лікувально-профілактичної допомоги новонародженим з малою масою тіла / П.В. Яворський // Буковинський мед. вісник. - 2010. - № 1 (53). - Т. 14. - С. 98-100.

28. Acute interstitial pneumonia / D. Bouros, A.C. Nicholson, V. Polychronopoulos, R.M. du Bois // Eur. Respir. J. - 2013. - Vol. 15 (2). - P. 412-418.

29. Alcon A. Pathophysiology of pneumonia / A. Alcon, N. Fabregas, A. Torres // Clin. Chest. Med. - 2008. - Mar.; vol. 26 (1). - P. 39-46.

30. Atomic force microscopic investigation of respiratory syncytial virus infection in HEp-2 cells / P.M. Tiwari, E. Eroglu, S. Boyoglu-Barnum [et al.] // J. Microsc. - 2014. - Jan.; Vol. 253 (1). - P. 31-41. doi: 10.1111/jmi.12095. Epub 2013 Nov 19.

31. Baert A.L. Pediatric Chest Imaging / A.L. Baert, M. Knauth, K. Sartor //Berlin: Springer-Verlag Berlin Heidelberg, 2008 - 2nd ed. - P. 417-440.

32. Cevey-Macherel M. Etiology of community-acquired pneumonia in hospitalized children based on WHO clinical guidelines / M. CeveyMacherel, A. Galetto-Lacour, A. Gervaix // Eur. J. Pediatr. - 2009. P. $168 .-$ P. 1429 
33. Comparison of ultrasound and CT in the evaluation of pneumonia complicated by parapneumonic effusion in children / J. Kurian, T.L. Levin, B.K. Han [et al.] // AJR. Am. J. Roentgenol. 2009. - Dec.; Vol. 193 (6). - P. 1648-1654.

34. Focal necrotizing pneumonia is a distinct entity from lung abscess / H. Seo, S.I. Cha, K.M. Shin [et al.] / Respirology. - 2013. Oct.; Vol. 18 (7). - P. 1095-1100.

35. Intra and interobserver reliability of the interpretation of high-resolution computed tomography on the lungs of prematureinfants / M.C. Boechat, R.R. Mello, M.V. Dutra [et al.] // Sao Paulo Med. J. 2010. - May; Vol. 128 (3). - P. 130-136.

36. Lucaya J. High-resolution CT of the lung in children. technique, indications, anatomy, features of lung disease, and clinical application / Lucaya J.Le Pointe // In: Lucaya J., Strife J.L., editors. Pediatric chest imaging: Chest imaging in infants and children. - Berlin: Springer Verlag, 2002. - P. 55-92.

37. Lung ultrasound in pediatric pneumonia. The persistent need of chest X-rays / D. Catalano, M. Sperandeo, M.C. Sacco, G. Trovato // Pediatric. Pulmonology (Impact Factor: 2.38) - 2013. - Vol. 10.
38. Pediatric lung abscess: a retrospective review of 23 cases / C.C. Yen, R.B. Tang, S.J. Chen, T.W. Chin // J. Microbiol. Immunol. Infect. - 2009. - Feb.; Vol. 37 (1). - P. 45-49.

39. Rudan I. Epidemiology and etiology of childhood pneumonia / I. Rudan, C. Boschi-Pinto, Z. Biloglav // Bull. WHO. - 2008. - Vol. 86. - P. 408.

40. Singh Y.D. Pathophysiology of Community Acquired Pneumonia / Y.D. Singh // Supplement to Japi. - 2012. - Jan.,Vol. 60.

41. The predicted increased cancer risk associated with a single computed tomography examination for calculus detection in pediatric patients compared with the natural cancer incedents / L.R. Kuhns, W.J. Oliver, E. Christodoulou, M.M. Goodsitt // Pediatr. Emerg. Care. - 2011. Apr.; Vol. 27 (4). - P. 345-350.

42. Unsuspected Pneumocystis carinii pneumonia at presentation of severe primary immunodeiciency / J.E. Berrington, T.J. Flood, M. Abinun [et al.] // Arch. Dis. Child. - 2009. - Vol. 82. - P. 144-147.

43. Virus detection in bronchoalveolar lavage fluid of 122 children with severe pneumonia / L.Y. Xie, L.L. Zhong, B. Zhang [et al.] // Zhonghua Shi Yan He Lin Chuang Bing Du Xue Za Zhi. - 2013. Apr.; Vol. 27 (2). - P. 95-97.

\section{Лучевые и морфоклинические аспекты диагностики пневмоний и их осложнений у новорожденных с низкой массой тела}

\section{А.П. Сорочан, И.А. Вороньжев, И.Е. Крамной}

Харьковская медицинская академия последипломного образования, г Харьков, Украина

Резюме. В обзоре литературы приведены современные взгляды на проблему острых воспалительных заболеваний легких у новорожденных детей, особенно у детей с экстремально низкой массой тела. Освещены вопросы актуальности и эпидемиологии проблемы острых воспалительных заболеваний (особенно пневмоний и их осложнений) у новорожденных детей с экстремально малой массой тела, особенности патоморфологии данного ряда заболеваний, наиболее характерные клинические признаки у этого контингента больных с изложением данных лабораторноинструментальных методов, а также всесторонне рассмотрены проблемы диагностики этих заболеваний при помощи лучевых методов, таких как: рентгенография, компьютерная томография, ультразвуковая диагностика. Изложены вопросы диффференциальной диагностики.

Ключевые слова: рентгенография, новорожденные с экстремально малой массой тела, воспалительные заболевания легких.

PERINATOLOGIYA I PEDIATRIYA.2015.2(62):56-61;doi10.15574/PP.2015.62.56

Radiologcal, morphological and clinical data in diagnostics pneumonia and it complications in low birth weight infants O.P. Sorochan, I.O. Voron'zev, I.O. Kramniy

Kharkiv Medical Academy of Postgraduate Education, Kharkiv, Ukraine

Summary. A review of literature with the contemporary views on the problem of acute inflammatory lung disease in newborns, particularly in children with extremely low birth weight. Detail highlights the relevance and epidemiology problems of acute inflammatory diseases in newborns with extremely low birth weight. Pathomorphological features of inflammatory lung diseases, particular qualities of clinic in this population. Also completely investigates problem of diagnostics of either diseases using radiological methods, such as chest X-ray, computed tomography, ultrasound diagnostics.

Key words: chest X-ray, extremely low birth weight infants, inflammatory lung disease.

\section{Сведения об авторах:}

Сорочан Алексей Павлович - клин. ординатор каф. рентгенологии и детской рентгенологии ХМАПО

Адрес: г. Харьков, ул. Корчагинцев, 58; тел. (057) 725-24-71; e-mail: sorochanop@gmail.com.

Вороньжев Игорь Александрович - проф. каф. каф. рентгенологии и детской рентгенологии ХМАПО.

Адрес: г. Харьков, ул. Корчагинцев, 58; тел. (057) 725-24-71.

Крамный Иван Емельянович - доц. каф. рентгенологии и детской рентгенологии ХМАПО.

Адрес: г. Харьков, ул. Корчагинцев, 58; тел. (057) 725-24-71.

Статья поступила в редакцию 4.04.2015 г. 


\title{
В.М. Дудник, 0.0. Зборовська \\ Предиктори розвитку серцевої недостатності в дітей з вродженими вадами серця після оперативної корекції
}

Вінницький національний медичний університет імені М.І. Пирогова, м. Вінниця, Україна

\author{
PERINATOLOGIYA I PEDIATRIYA.2015.2(62):62-65;doi10.15574/PP.2015.62.62
}

Мета - дослідити предиктори серцевої недостатності в дітей з вродженими вадами серця після оперативної корекції, оцінивши показники тканинної допплерограсії та вмісту галектину-3 в сироватці крові.

Пацієнти та методи. Обстежено 184 дитини з вродженими вадами серця після радикальної корекції (середній вік обстежених становив 9,54 0,36 року). Тривалість післяопераційного катамнезу дорівнювала від 1 місяця до 15,3 року. Усім дітям проведено тканинну допплерографію з визначенням міокардіальних швидкостей та вмісту галектину-3 у сироватці крові.

Результати. Встановлено, що підвищення вмісту галектину-3>6,21 нг/мл збільшувало шанси на клінічну маніфестацію СН в 1,89 разу (95\% Cl 1,094-4,491). Клінічні прояви серцевої недостатності в пацієнтів із вродженими валами серця супроводжувались зниженням систолічних міокардіальних швидкостей обох шлуночків, зокрема, зростали шанси на зниження S`мк<7,7 cm/c та S`тк<9,4 cm/c (0R=3,056; 95\% Cl 1,119-8,350 та OR=3,560; 95\% Cl 1,236-10,252 відповідно).

Висновки. Клінічна маніфестація серцевої недостатності в пацієнтів із вродженими вадами серця після оперативної корекції обумовлювалася зниженням систолічних міокардіальних швидкостей обох шлуночків, а також підвищенням вмісту в сироватці крові маркера фріброзоутворення галектину-3.

Ключові слова: вроджені вади серця, діти, серцева недостатність.

\section{Вступ}

В роджені вади серця (ВВС) є найбільш поширеною Заномалією розвитку в дітей і зустрічаються 3 частотою до $30 \%$ від усіх вроджених вад розвитку. На сьогодні серцеві вади є лідерами серед причин дитячої смертності від вроджених аномалій, а їх питома вага серед усіх зареєстрованих причин смерті в дитячому віці становить 14,2\%. Народжуваність дітей з ВВС, за різними статистичними даними, варіює в межах 1\% [4, 7]. Актуальність проблеми ВВС зумовлена не лише їх поширеністю, але й тим, що розвиток кардіохірургії у світі i, зокрема, в Україні, сприяє прогресивному збільшенню кількості дітей після оперативної корекції приблизно на $5 \%$ у рік [5]. Серед захворювань серцево-судинної системи головними показником, який визначає наслідки оперативної корекції, є серцева недостатність (CH) [2, 3]. Відомо, що після оперативної корекції ВВС через 1 рік 90\% пацієнтів відповідає першому функціональному класу NYHA, а через 10 років - лише 56\%. Тому на сьогодні активно вивчаються інструментальні та біохімічні маркери, що є предикторами розвитку міокардіальної дисфункції [4]. Для діагностики СН, крім клінічних проявів, необхідним є об'єктивне підтвердження аномальної скоротливої здатності шлуночків. Метод тканинної допплерографії (ТД) дає змогу оцінити поздовжній рух стінок лівого (ЛШ) і правого шлуночків (ПШ) у різні фази серцевого циклу, робота яких порушується при патологічних станах насамперед у міокарді [6].

Більшість відомих біомаркерів СН (тропоніни, креатинфосфокіназа, міокардіальна фракція, мозковий натрійуретичний пептид) є наслідком патологічного процесу, а не причиною патологічного пошкодження міокарда [1]. Саме $з$ цієї причини активно вивчається роль інших біологічних факторів, які відіграють предикторну роль у процесах ремоделювання міокарда та розвитку міокардіальної дисфункції. Так, білок сімейства S-лектинів галектин-3 є одним із потужних предикторів ремоделювання міокарда, оскільки бере участь у багатьох фізіологічних і патологічних процесах, серед яких запалення і фіброз $\epsilon$ ключовими та сприяють розвитку й прогресуванню патофізіологічних механізмів при $\mathrm{CH}$ [8]. Біологічна дія галектину-3 реалізується через сприяння міграції макро- фагів, проліферації фібробластів і синтезу колагену в кардіоміоцитах [9].

Mema роботи - визначити предиктори $\mathrm{CH}$ у дітей з ВВС після оперативної корекції, оцінивши показники ТК та вмісту галектину-3 в сироватці крові.

\section{Матеріали та методи дослідження}

Нами обстежено 184 дитини з ВВС після радикальної корекції у віці від 1 місяця до 18 років (середній вік обстежених становив 9,54 $\pm 0,36$ року). Тривалість післяопераційного катамнезу дорівнювала від 1 місяця до 15,3 року. Верифікація діагнозу ВВС та СН проведена згідно з наказом МОЗ України від 19.07.2005 р. № 362 «Про затвердження Протоколів діагностики та лікування кардіоревматологічних хвороб у дітей» 3 урахуванням класифікації СН для пацієнтів дитячого віку Бєлоконь Н.О. (1987 р.) Залежно від типу гемодинамічних порушень хворі були розподілені на три групи: діти з ВВС зі збагаченням малого кола кровообігу (МКК); 3 ВВС із гіповолемією МКК; діти з ВВС зі збідненням системного кровообігу. Група серцевих аномалій зі збагаченням МКК була представлена дефектами міжпередсердної та міжшлуночкової перетинки, зі збідненням МКК тетрадою Фалло та подвійним відходженням магістральних судин від ПШ (тетрадний тип), а група дітей з ВВС із збідненням системного кровообігу була сформована з пацієнтів, прооперованих із приводу коарктації аорти та вродженого стенозу аорти.

Матеріали дослідження відповідали основним біоетичним нормам Гельсінської декларації, прийнятої Генеральною асамблеєю Всесвітньої медичної конвенції, Конвенції Ради Європи про права людини та біомедицини (1977р.).

Для оцінки систолічної та діастолічної функції міокарда всім пацієнтам проведено ехокардіографію (Exо-КГ) на апараті «Philips HD11 XE» датчиком от 3,5 до 7 МГц, з дотриманням правил, регламентованих Американською асоціацією ехокардіографії (Guidelines and Standards for Performance of a Pediatric Echocardiogram: A Report from the Task Force of the Pediatric Council of the American Society of Echocardiography, 2006). Ультразвукове дослідження (УЗД) проведено з використанням В- i 
Ехокардіографічні показники систолічної функції міокарда лівого шлуночка

Таблиия 1

в обстежених дітей залежно від клінічних проявів серцевої недостатності

\begin{tabular}{|c|c|c|c|c|}
\hline \multirow{2}{*}{ Показник } & \multicolumn{3}{|c|}{ Діти з ВВС, n=184 } & \multirow{2}{*}{ Здорові діти, n=40 } \\
\hline & CH 0 cт., $n=20$ & CH I CT., n=138 & CH II cT., n=26 & \\
\hline$\Phi B, \%$ & $64,40 \pm 0,85^{*}$ & $65,41 \pm 0,50^{*}$ & $62,62 \pm 1,18^{*}$ & $69,03 \pm 0,64$ \\
\hline $\mathrm{S}_{\mathrm{MK},}, \mathrm{CM} / \mathrm{C}$ & $8,40 \pm 0,29^{*}$ & $8,15 \pm 0,32^{*}$ & $7,66 \pm 0,11^{* ; * *}$ & $9,85 \pm 0,28$ \\
\hline $\mathrm{S}_{\text {мшп, }, \mathrm{CM} / \mathrm{C}}$ & $7,18 \pm 0,25^{*}$ & $6,45 \pm 0,08^{* ; * *}$ & $6,54 \pm 0,16^{* ; * *}$ & $7,93 \pm 0,13$ \\
\hline
\end{tabular}

Примітки: $1 .{ }^{*}-\mathrm{p}<0,05$ - різниця вірогідна відносно показників здорових дітей; ** - $<0,05$ - різниця вірогідна відносно показників дітей з ВВС без клінічних проявів СН

Ехокардіографічні показники систолічної функції міокарда правого шлуночка

Таблиия 2 в обстежених дітей залежно від клінічних проявів серцевої недостатності

\begin{tabular}{|c|c|c|c|c|}
\hline \multirow{2}{*}{ Показник } & \multicolumn{3}{|c|}{ Діти з ВВС, n=184 } & \multirow{2}{*}{ Здорові діти, n=40 } \\
\hline & CH 0 ст., $n=20$ & CH I CT., $n=138$ & CH II CT., $n=26$ & \\
\hline TAPSE, cM & $1,49 \pm 0,07^{*}$ & $1,46 \pm 0,03^{*}$ & $1,56 \pm 0,07^{*}$ & $2,14 \pm 0,03$ \\
\hline $\mathrm{S}_{\mathrm{TK}}^{\prime} \mathrm{CM} / \mathrm{C}$ & $10,71 \pm 0,45^{*}$ & $9,58 \pm 0,13^{* ; * *}$ & $9,55 \pm 0,34^{* ; * *}$ & $12,8 \pm 0,17$ \\
\hline
\end{tabular}

Примітки: * - $<0,01$ - різниця вірогідна відносно показників здорових дітей; ** $-\mathrm{p}<0,05-$ різниця вірогідна відносно показників дітей з ВВС без клінічних проявів $\mathrm{CH}$.

М-режимів, допплер-Ехо-КГ і ТД в імпульсно-хвильовому режимі. Для оцінки систолічної функції ЛШ визначено фракцію викиду (ФВ) за формулою Teichholz L. та пікову систолічну міокардіальну швидкість руху латеральної частини фіброзного кільця мітрального клапана $\left(\mathrm{S}_{\text {мк, }} \mathrm{cm} / \mathrm{c}\right)$ та на рівні базальної частини міжшлуночкової

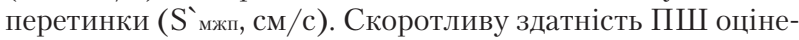
но шляхом визначення амплітуди руху площини фіброзного кільця тристулкового клапану (TAPSE, см), а також за піковою систолічною міокардіальною швидкістю руху латеральної частини фіброзного кільця тристулкового клапану ( $\left.\mathrm{S}_{\text {тк, }} \mathrm{cm} / \mathrm{c}\right)$. Вміст галектину-3 у сироватці крові визначено імуноферментним методом за набором «Human Galectin-3» (Platinum ELISA; eBioscience, Bender MedSystems, Австрія) відповідно до інструкції фірми-виробника. Рівні галектину-3 розподілено за допомогою статистичного методу поділу варіаційних рядів на квартилі: I квартиль - менше 5,62 нг/мл, II квартиль 5,62-6,21 нг/мл, III квартиль - 6,22-7,73 нг/мл, IV квартиль - понад 7,73 г/мл.

До контрольної групи увійшло 40 здорових дітей, яким виконано весь спектр клінічного, лабораторного та інструментального досліджень.

Статистична обробка отриманих результатів проведена за допомогою програми IBM SPSS Statistics, версія 20 (2013 р.) із застосуванням параметричних і непараметричних методів оцінки отриманих результатів. Для кожної групи показників вирахувано середне арифметичне $(\mathrm{M})$, середнє квадратичне відхилення $(\sigma)$, середню помилку (m). Достовірність різниці між середніми значеннями оцінена за таблицею критеріїв Стьюдента для непараметричних показників. Різниця була достовірною при $\mathrm{p}<0,05$. Оцінка ступеня впливу факторних ознак проведена за показником відношення шансів (OR) із довірчим інтервалом (СI) 95\%.

\section{Результати дослідження та їх обговорення}

Встановлено, що серед дітей з ВВС після оперативної корекції клінічна маніфестація СН спостерігалась у 164 $(89,13 \pm 2,30 \%)$ дітей. У переважної більшості відмічалась

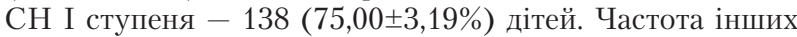
ступенів СН була достовірно меншою $(\mathrm{p}<0,01)$ і становила 14,13 $\pm 2,57 \%$ для СН IIA, клінічні прояви СН не виявлялися у $10,87 \pm 2,29 \%$ хворих.
Слід зазначити, що зниження ФВ відмічалось лише у 20 дітей з ВВС (10,87\%). На відміну від неї, при оцінці систолічної функції міокарда за даними Тд виявлялося зниження швидкісних показників поздовжньої скоротливості ЛШ у $141(76,63 \pm 3,12 \%)$ хворого. Так, показник $\mathrm{S}_{\text {мк }}$ у хворих дітей був достовірно нижчим $(\mathrm{p}<0,01)$ порівняно зі здоровими - відповідно 7,81 $\pm 0,10 \mathrm{~cm} / \mathrm{c}$ та 9,85 $\pm 0,28$ cм/с. Зокрема, у дітей з ВВС зі збідненням системного кровообігу швидкість S`мк була меншою за показники здорових дітей в 1,51 разу $(\mathrm{p}<0,01)$.

За даними ТД, зниження швидкісних показників поздовжньої скоротливості ПШ відмічалось у 133 (72,28\%) дітей. Зокрема, спостерігалися зміни показника $\mathrm{S}_{\text {тк }}$

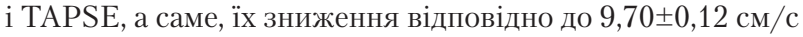
i 1,48 $\pm 0,02 \mathrm{~cm} / \mathrm{c}$, що на 31,96\% і 44,59\% було меншим, ніж у здорових дітей. Аналіз зазначених показників залежно від гемодинамічного типу ВВС показав, що найбільші відмінності спостерігалися при вадах серця, що супроводжувалися порушенням кровообігу в МКК. Так, при ВВС зі збагаченням МКК TAPSE був в 1,51 разу достовірно меншим $(1,42 \pm 0,02 \mathrm{~cm}, \mathrm{p}<0,01)$, а $\mathrm{S}_{\text {тк }}^{\prime}-$ в 1,33 разу $(9,62 \pm 0,11 \mathrm{~cm} / \mathrm{c}, \mathrm{p}<0,01)$ порівняно зі здоровими дітьми. Своєю чергою, вади зі збідненням МКК супроводжувалися зменшенням TAPSE в 1,67 разу $(1,28 \pm 0,03$ см,

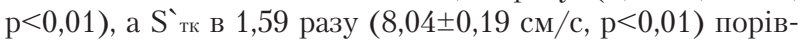
няно з групою здорових дітей і достовірно відрізнялися від показників при інших типах вад серця $(\mathrm{p}<0,01)$.

Проводилось дослідження показників скоротливої функції міокарда обох шлуночків серця залежно від наявності та ступеня вираженості клінічних проявів СН. Нами встановлено, що в групі хворих дітей Ехо-КГ показники

Таблиия 3

Аналіз відношення шансів (OR) розвитку серцевої недостатності в дітей з вродженими вадами серця після оперативної корекції залежно від інструментальних показників систолічної функції міокарда шлуночків

\begin{tabular}{|l|c|c|}
\hline \multicolumn{1}{|c|}{ Показник } & OR & CI $\mathbf{9 5 \%}$ \\
\hline$\Phi B<60 \%$ & 2,490 & $0,315-19,670$ \\
\hline$S^{\prime}{ }_{\text {мк }}<7,7 \mathrm{~cm} / \mathrm{c}$ & $\mathbf{3 , 0 5 6}$ & $\mathbf{1 , 1 1 9 - 8 , 3 5 0}$ \\
\hline $\mathrm{S}^{\prime}{ }_{\text {мшп }}<6,5 \mathrm{~cm} / \mathrm{c}$ & 2,048 & $0,777-5,394$ \\
\hline TAPSE $<1,4 \mathrm{~cm}$ & 0,838 & $0,330-2,130$ \\
\hline $\mathrm{S}^{\prime}{ }_{\mathrm{TK}}<9,4 \mathrm{~cm} / \mathrm{c}$ & $\mathbf{3 , 5 6 0}$ & $\mathbf{1 , 2 3 6 - 1 0 , 2 5 2}$ \\
\hline
\end{tabular}




\section{Вміст галектину-3 в сироватці крові залежно від ступеня серцевої недостатності в дітей}

Таблиия 4 з вродженими вадами серця після оперативної корекції

\begin{tabular}{|c|c|c|c|c|}
\hline \multirow{2}{*}{ Показник } & \multicolumn{3}{|c|}{ Діти з ВBC, n=184 } & \multirow{2}{*}{ Здорові діти, n=40 } \\
\hline & CH 0 CT., $n=20$ & CH I CT., $n=138$ & CH II CT., $n=26$ & \\
\hline Галектин-3, нг/мл & $6,59 \pm 0,43^{*}$ & $6,98 \pm 0,23^{*}$ & $7,66 \pm 0,26^{* \cdot * *}$ & $4,17 \pm 0,17$ \\
\hline
\end{tabular}

Примітки: * - p <0,01 - різниця вірогідна відносно показників здорових дітей; ** - $<0,05$ - різниця вірогідна відносно показників дітей без клінічних

систолічної функції міокарда ЛШ були достовірно нижчими за показники здорових дітей при всіх ступенях $\mathrm{CH}$, а також у тих випадках, коли клінічно не відмічались ознаки СН $(\mathrm{p}<0,01)$. Зокрема, слід зазначити, що швидкісні показники контрактильної функції міокарда ЛШ за даними ТД поступово знижувались у міру прогресування СН. Так, міокардіальні швидкості $S_{\text {мк }}^{\prime}(7,66 \pm 0,11$ см с) i $\mathrm{S}_{\text {мшп }}(6,54 \pm 0,16 \mathrm{~cm} / \mathrm{c})$ у дітей $3 \mathrm{BBC}$ i CH II ст. були на $9,7 \%$ і 9,8\% зниженими порівняно з подібними показниками у пацієнтів із ВBC, які не мали клінічних проявів СН $(8,40 \pm 0,29 \mathrm{~cm} / \mathrm{c}$ і 7,18 $\pm 0,25 \mathrm{~cm} / \mathrm{c}$ відповідно) $(\mathrm{p}<0,05)$ (табл. 1).

Показник TAPSE достовірно відрізнявся від показників здорових дітей при всіх ступенях СН $(\mathrm{p}<0,01)$ Так, при СН I ступеня амплітуда TAPSE зменшувалась в 1,47 разу $(1,46 \pm 0,03$ см), а при $\mathrm{CH}$ II ступеня в 1,37 разу $(1,56 \pm 0,07$ см $)$ порівняно з показником здорових дітей $(2,14 \pm 0,03$ см). Слід зазначити, що в дітей, в яких клінічно не діагностувалися CH, TAPSE також був достовірно меншим за показник здорових дітей в 1,44 разу $(1,49 \pm 0,07$ см, p<0,01). При аналізі даних ТД спостерігалася чітка тенденція зниження систолічної швидкості $\mathrm{S}_{\mathrm{T}}$ у мірі прогресування клінічних проявів СН у дітей з ВВС після оперативної корекції. Навіть за відсутності клінічних проявів $\mathrm{CH}$ у хворих дітей швидкість $\mathrm{S}^{\prime}{ }_{\text {тк }}$ була достовірно меншою за показник здорових дітей в 1,20 разу $(10,71 \pm 0,45 \mathrm{~cm} / \mathrm{c}$ та $12,8 \pm 0,17 \mathrm{~cm} / \mathrm{c}$ відповідно, $\mathrm{p}<0,01)$. Своєю чергою, швидкість $\mathrm{S}^{`}$ тк при СН I $(9,58 \pm 0,13 \mathrm{~cm} / \mathrm{c})$ та II ступенів $(9,55 \pm 0,34 \mathrm{~cm} / \mathrm{c})$ відрізнялась від результатів здорових дітей в 1,34 разу $(\mathrm{p}<0,01)$, а також була достовірно меншою за показники дітей з ВВС без клінічно діагностованої СН ( $<0,05)$, (табл. 2).

У дітей з ВВС після оперативної корекції, за даними ТД, зниження систолічних швидкостей руху фіброзних кілець атріовентрикулярних клапанів підвищувало шанси на розвиток $\mathrm{CH}$ в $3,05-3,56$ разу $\left(\mathrm{S}_{\text {мк }}<7,7 \mathrm{~cm} / \mathrm{c}\right.$ : $\mathrm{OR}=3,056 ; 95 \%$ CI 1,119-8,350; $\mathrm{S}_{\text {тк }}<9,4: \quad \mathrm{OR}=3,560$; 95\% CI 1,236-10,252), (табл. 3).

У всіх дітей з ВВС вміст галектину-3 в сироватці крові становив 7,04 $\pm 0,21$ (нг/мл) і достовірно перевищував показники здорових дітей $(4,17 \pm 0,17$ нг/мл) $(\mathrm{p}<0,01)$. Аналіз змін його рівня залежно від гемодинамічного типу вади серця встановив його достовірне підвищення в 1,36-2,02 разу при всіх типах ВBC $(\mathrm{p}<0,01)$ Проте при ВВС зі збідненням системного кола кровообігу рівень галектину-3 перевищував подібний при вадах зі збідненням МКК на $48,00 \%(\mathrm{p}<0,01)$.

При аналізі показників вмісту галектину-3 у сироватці крові залежно від ступеня СН спостерігалася чітка тенденція до збільшення його рівня в міру прогресування клінічних проявів $\mathrm{CH}$ у дітей з ВВС після оперативної корекції. Навіть при відсутності клінічних ознак декомпенсації серцевої діяльності у хворих дітей рівень галектину-3 вже був достовірно вищим за показник здорових дітей в 1,58 разу $(6,59 \pm 0,43$ нг/мл та $4,17 \pm 0,17$ нг/мл, $\mathrm{p}<0,01$ ), (табл. 4).

Відповідно при I та II ступенях СН сироватковий рівень галектину-3 перевищував даний показник у здорових дітей в 1,67 та 1,84 разу $(\mathrm{p}<0,01)$. Крім того, при $\mathrm{CH}$ II ступеня рівень галектину-3 достовірно перевищував (на $16,24 \%, p<0,05)$ аналогічний показник у дітей з ВBC без клінічних ознак $\mathrm{CH}$, а шанси на його зростання понад 6,21 нг/мл збільшувались майже вдвічі ( $\mathrm{OR}=1,889 ; 95 \%$ CI 1,094-4,491).

\section{Висновки}

У 72,28-76,63\% дітей з ВВС спостерігалося зниження показників поздовжньої скоротливості ЛШ та ПШ відповідно, причому зміна спектра ТК ЛШ у систолу випереджала інші показники його глобальної скоротливості, а саме, зниження пікової систолічної міокардіальної швидкості $\left(\mathrm{S}_{\text {мк }}\right)$ реєструвалося в 7,05 разу частіше, ніж падіння ФВ.

При оцінці контрактильної функції ПШ спостерігалися паралельні зміни показників $\mathrm{S}_{\text {тк }}$ i TAPSE, а саме, ix зниження відповідно на 31,96\% і 44,59\% порівняно з групою здорових дітей.

Аналіз вмісту галектину-3 у сироватці крові показав його підвищення в 1,36-2,02 разу при всіх гемодинамічних типах $\mathrm{BBC}(\mathrm{p}<0,01)$ порівняно зі здоровими дітьми, особливо помітне при збідненні системного кровообігу. У міру прогресування СН зростав рівень галектину-3 в $1,67-1,84$ разу $(\mathrm{p}<0,01)$ порівняно зі здоровими дітьми, а шанси на його зростання понад 6,21 нг/мл навіть за відсутності клінічних ознак декомпенсації серцевої діяльності збільшувалися майже удвічі $(\mathrm{OR}=1,889 ; 95 \% \mathrm{CI}$ $1,094-4,491)$.

\section{ЛITEPATУРA}

1. Вашакидзе 3.С. Галектин-3 - новый биомаркер сердечной недостаточности, воспаления и фиброза / З.С. Вашакидзе, В.И. Целуйко, Т.Р. Брегвадзе // Серцева недостатність. 2011. - № 3. - С. 73-76.

2. Гончарь М.О. Систолічна і діастолічна функція серця у дітей з септальними дефектами до і після оперативної корекції /
М.О. Гончарь, Г.С. Сенаторова // Современная педиатрия. 2010. - № 3. - С. 166-169

3. Гончарь М.О. Стан міокарда в дітей із природженими вадами серця у віддалений період після хірургічної корекції / М.О. Гончарь // Здоровье ребенка. - 2010. - № 3. C. 42-44. 
4. Зиньковский М.Ф. Врожденные пороки сердца / М.Ф. Зиньковский; ред. акад. А.Ф. Возианова. - Киев: Книга Плюс, 2009. - 1170 с.

5. Педіатричні аспекти ведення дітей з природженими вадами серця / ред. проф. Волосовець О.П. - Тернопіль: ТДМу, 2008. - 176 с.

6. Поташов С.В. Современная тканевая доплерография в клинической практике: возможности и области применения / С.В. Поташев // Серцева недостатність. - 2011. - № 2. - С. 2-13.

7. Birth Prevalence of Congenital Heart Disease Worldwide / van der Linde Denise, Elisabeth E. M. Konings,
Maarten A. Slager // JACC. - 2011. - № 58. P. 2241-2247.

8. David A. Morrow Galectin-3 in Cardiovascular Disease / David A Morrow, Michelle L. O'Donoghue // Journal of the Am. College of Cardiology. - 2012. - № 14. - P. 1257-1258.

9. Galectin-3, a Marker of Cardiac Fibrosis, Predicts Incident Heart Failure in the Community / Jennifer E. Ho, Chunyu Liu, Asya Lyass [et al.] // Journal of the Am. College of Cardiology. - 2012. № 14. - P. $1249-1256$.

\section{Предикторы развития сердечной недостаточности у детей с врожденными пороками сердца после оперативной коррекции В.М. Дудник, О.А. Зборовская}

Винницкий национальный медицинский университет имени М.И. Пирогова, г. Винница, Украина Цель - исследовать предикторы сердечной недостаточности у детей с врожденными пороками сердца после оперативной коррекции путем оценки показателей тканевой допплерограсии и содержания галектина-3 в сыворотке крови.

Пациенты и методы. Обследовано 184 ребенка с врожденными пороками сердца после радикальной коррекции (средний возраст обследованных составлял 9,54ะ0,36 года). Продолжительность послеоперационного катамнеза составляла от 1 месяца до 15,3 года. Всем детям проведена тканевая допплерография с определением миокардиальных скоростей и определялось содержание галектину-3 в сыворотке крови.

Результаты. Повышение содержания галектину-3>6,21 нг/мл увеличивало шансы на клиническую манифестацию сердечной недостаточности в 1,89 раза (95\% Cl 1,094-4,491). Клинические проявления сердечной недостаточности у пациентов с врожденными пороками сердца сопровождались снижением систолических миокардиальных скоростей обоих желудочков, а именно, увеличивались шансы на снижение S`мк<7,7 см/с и S`тK<9,4 cм/с (OR=3,056; 95\% Cl 1,119-8,350 и 0R=3,560; 95\% Cl 1,236-10,252 соответственно).

Выводы. Клиническая манифестация сердечной недостаточности у пациентов с врожденными пороками сердца после оперативной коррекции обусловливалась снижением систолических миокардиальных скоростей обоих желудочков, а также повышением содержания в сыворотке крови маркера фриброзообразования галектина-3.

Ключевые слова: врожденные пороки сердца, дети, сердечная недостаточность.

PERINATOLOGIYA I PEDIATRIYA.2015.2(62):62-65; doi10.15574/PP.2015.62.62

Predictors of the development of the heart failure in children with congenital heart defects after the surgical correction V.M. Dudnyk, 0.0. Zborovska

Pirogov National Medical University, Vinnytsia, Ukraine

Purpose - estimated predictors of the development of the heart failure in children with congenital heart defects after the surgical correction due to the evaluation of the results of the tissue doplerography and content of galectin-3 in serum.

Patients and methods. Checked 184 patients with congenital heart defects after the surgical correction with the average age of them $9.54 \pm 0.36$ years. Duration of the postoperative katamnesis was from 1 month up to 15.3 years. All children were provided with tissue doplerography with evaluation of the myocardial speeds and content of the galectin-3 in serum.

Results. Found that increased content of galectin-3 $>6,21 \mathrm{ng} / \mathrm{ml}$ increased risk of the clinical manifestation of the heart failure in 1.89 times $(95 \% \mathrm{Cl}$ 1.094-4.491).Clinical presentation of the heart failure appeared due to changes of the systolic function of the both ventricles, especially were increased risks of the decreasing of $S^{\prime}{ }^{\prime} \mathrm{mv}<7,7 \mathrm{~cm} / \mathrm{C}$ and $\mathrm{S}^{\prime} \mathrm{tv}<9,4 \mathrm{~cm} / \mathrm{c}(\mathrm{OR}=3.056 ; 95 \% \mathrm{Cl} 1.119-8.350$ and $0 \mathrm{R}=3.560 ; 95 \% \mathrm{Cl} 1.236-10.252$, in accordance).

Conclusions. Clinical presentation of the heart failure in patients with congenital heart defects after the surgical correction was caused with systolic disorders of the both ventricles, and as well increasing of the marker of the fibrotic process galectin-3.

Key words: congenital heart defects, children, heart failure.

Сведения об авторах:

Дудник Вероника Михайловна - д.мед.н., проф., зав. каф. педиатрии №2 Винницкого НМУ им. М.И. Пирогова.

Адрес: г. Винница, ул. Пирогова М.I, 46; e-mail: dudnykv@mail.ru.

Зборовская Ольга Александровна - ассистент каф. каф. педиатрии №2 Винницкого НМУ им. М.И. Пирогова.

Адрес: г. Винница, ул. Пирогова М.I, 46; e-mail: olga-zborovskaya@mail.ru.

Статья поступила в редакцию 30.03.2015 г. 


\title{
В.Б. Ніколаєнко, Т.А. Полук, Л.І. Омельченко
}

\section{Особливості дебюту ювенільного псоріатичного артриту (клінічний випадок)}

\author{
ДУ «Інститут педіатрії акушерства і гінекології НАМН України», м. Київ, Україна
}

\author{
PERINATOLOGIYA I PEDIATRIYA.2015.2(62):66-70;doi10.15574/PP.2015.62.66
}

Резюме. Стаття присвячена проблемам діагностики псоріатичного артриту в дітей у дебюті захворювання. Описано особливості ураження шкіри та суглобів при різних клінічних варіантах перебігу захворювання. Наведено найбільш інформативні діагностичні критерії ювенільного псоріатичного артриту. Представлено клінічний випадок ювенільного псоріатичного артриту із системним варіантом дебюту та атиповим ураженням шкіри. Ключові слова: ювенільний псоріатичний артрит, дебют, діти.

$\mathrm{C}$ воєчасна діагностика псоріатичного артриту (ПсА) у дітей (код за МКХ-10 М 09.0 - юнацький артрит при псоріазі) становить одну з найбільш актуальних проблем педіатричної ревматології. Особливі труднощі виникають у ситуаціях, коли суглобовий синдром випереджає появу шкірних змін або при атипових шкірних проявах псоріазу [2, 3].

Псоріаз виявляється у 1-2\% пацієнтів (за деякими даними, до 6\%) і вважається одним із найбільш поширених шкірних захворювань, посідаючи серед хронічних дерматозів друге місце після атопічного дерматиту. Він може зустрічатись навіть у новонароджених і грудних дітей. Протягом останнього десятиліття зростає рівень захворюваності серед дітей молодшого шкільного віку [9].

Етіопатогенез псоріазу остаточно не вивчений, але більшість дослідників визнає мультифакторний тип успадкування 3 неповною пенетрантністю гену. До найбільш частих тригерних факторів відносять інфекційні захворювання (гострі респіраторні вірусні інфекції ГРВІ, ангіни, вітряну віспу, кір), емоційно-психологічні стреси, вплив несприятливих чинників зовнішнього середовища (гіперінсоляцію, переохолодження) [5, 6].

У дітей ураження локалізуються практично в тих самих ділянках тіла, що й у дорослих, однак у них набагато частіше (30\% та 5,6\% випадків відповідно) залучається шкіра обличчя [7]. Висипання можуть бути на чолі й щоках, супроводжуватися почервонінням шкіри, поширюватись на повіки і вуха. Можлива локалізація уражень на слизових оболонках роту з десквамацією епітелію та появою своєрідних плям на язиці («географічний язик»), на долонях і підошвах - 3 розвитком гіперкератозу, у складках шкіри (пахвових, пахвинних, шийних) і навколопупковій області (у немовлят), у третини дітей виявляються «наперсткоподібні» зміни нігтів на руках і ногах. Найчастіше ураження шкіри в дітей при псоріазі локалізуються на ліктях, колінах, попереку і волосистій частині голови, у 30\% випадків висипання супроводжуються свербежем. У дітей часто спостерігається феномен Кюбнера, що полягає в появі псоріатичних висипань у ділянках травмування або подразнення шкіри.

Можливий розвиток універсальної псоріатичної еритродермії (ексфоліативного дерматиту) або еритеми, яка часто на початку захворювання ховається у волосистій частині голови, міжсідничній складці. Псоріатична еритродермія та пустульозний псоріаз характеризуються тяжким перебігом із наявністю соматичних уражень і резистентністю до традиційного лікування [4].

У кожного третього-п'ятого пацієнта псоріаз ускладнюється специфічним артритом, із них 6-7\% дітей до 16 років, при цьому в більшості хворих відсутня чітка хронологічна залежність між ураженням шкіри та суглобів.
У 15-25\% пацієнтів, переважно в дітей, шкірні прояви виникають лише через рік після дебюту артриту [5]. Частота ювенільного ПсА становить до 5\% від загального числа дітей, хворих на хронічні артрити [7]. За даними десятирічного реєстру ДУ «ППАГ НАМН України», ювенільний ПсА спостерігається у $2 \%$ пацієнтів.

Псоріатичний ювенільний артрит виникає переважно у віці 9-12 років, у дівчаток у 2 рази частіше, ніж у хлопчиків. Клініка та перебіг ПсА мають багато спільного 3 повільно прогресуючим варіантом ювенільного хронічного артриту [8]. За класифікаціями Європейської протиревматичної ліги (EULAR) та Міжнародної ліги ревматологічних асоціацій (ILAR), ПсА у дітей відносять до ювенільного ідіопатичного артриту (ЮІА).

У дебюті ПсА частіше відмічається ураження одного або небагатьох, асиметрично розташованих крупних суглобів із нерізкими змінами їхньої форми та незначним порушенням функції. Лише в незначної кількості пацієнтів артрит перебігає гостро з вираженим набряком суглобів. Для ПсА типовим є ураження дистальних міжфалангових суглобів кистей, міжфалангового суглоба I пальця та проксимального міжфалангового суглоба $\mathrm{V}$ пальця кистей, а також трьох суглобів одного й того самого пальця кисті або стопи («вісьове ураження») 3 ураженням сухожилків і вираженою періостальною реакцією [9]. Також характерним є розвиток сакроілеїту, як правило, одностороннього. Суглобовому синдрому притаманна наявність різкого «морфінного» болю, що посилюється при найменшому русі, навіть за відсутності вираженого синовіїту [6].

Шкіра над ураженими суглобами може мати характерний синюшно-багровий відтінок. Чітко визначаються зміни периартикулярних тканин, особливо помітні при ураженні дистальних міжфалангових суглобів кистей: вони стають щільними, напруженими, рожевого кольору; пальці мають вигляд «ковбасок» або «редисок». Рідше розвивається акроостеоліз.

При генералізованому процесі можуть залучатися інші суглоби, з вираженою різкою болючістю, дефігурацією, локальною гіперемією шкіри та зменшенням обсягу рухів. Ранкова скутість, тендосиновіїти відмічаються рідко.

На рентгенограмах суглобів виявляється остеопороз, можуть спостерігатися ознаки кістково-хрящової деструкції в поєднанні зі склеротичними змінами, крайовими виростами, вогнищевим ущільненням кісткової структури, остеолізом кінцевих фаланг тощо. Одночасно виявляються остеодеструктивні та остеопроліферативні процеси. Може відмічатися передчасне закриття зон росту.

Відхилення в даних лабораторного дослідження відповідають ступеню вираженості суглобових і вісцеральних проявів. Для периферичної крові характерні нормаль- 
на або збільшена швидкість осідання еритроцитів (ШОЕ), залежно від ступеня активності артриту, непостійний і невисокий нейтрофільоз, анемія, диспротеїнемія зі зменшенням вмісту альбумінів і гіпергамаглобулінемією. Для III ступеня активності характерне значне підвищення IgA та імунних комплексів у крові. Ревматоїдний і антинуклеарний фактори в крові визначаються рідко. Частота виявлення HLA-B27-антигену при ПсА становить приблизно $25 \%$.

За даними літератури [1, 2, 8], особливості перебігу дитячого ПсА такі:

- висока частота неспецифічних шкірних уражень: ексудативних або пустульозних форм, універсальної псоріатичної еритродермії (ексфоліативного дерматиту) або простої еритеми, яка ховається у волосистій частині голови, міжсідничній складці;

- дебют захворювання з моноолігоартриту суглобів кистей і в подальшому - розповсюдження на інші суглоби; у третини дітей початок хвороби нагадує гострий напад подагри;

- лінійне (аксіальне) ураження всіх суглобів одного пальця кистей або стоп з ураженням сухожилків і вираженою периостальною реакцією;

- менш агресивний перебіг, менш виражені функціональні порушення;

- рідке залучення грудинно-ключичних, скронево-нижньощелепних і кульшових суглобів;

- можливе відставання в рості хворої кінцівки у зв'язку з ушкодженням ростової зони;

- можливий розвиток у дебюті виражених системних проявів (лихоманки, гепатоспленомегалії, лімфаденопатіі).

Діагноз ПсА у дітей встановлюється на основі характерних симптомів: ураження дистальних міжфалангових суглобів і/або типове «вісьове ураження» суглобів кистей рук, асиметричне ураження суглобів, раннє ураження суглобів стоп, у тому числі великого пальця; біль у п'ятках (підп'ятковий бурсит); рецидивний перебіг артриту, односторонній сакроілеїт, характерні рентгенологічні зміни (особливо в ділянці кінцьових фаланг, відсутність епіфізарного остеопорозу, негативний ревматоїдний фактор (РФ) і наявність антигену HLA-B27 в крові. Діагноз стає більш вірогідним за наявності псоріазу в найближчих родичів пацієнта і визначеним - при виявленні типових для псоріазу змін шкіри i/або нігтів (при цьому слід враховувати незначність висипань та їх незвичайну локалізацію). Наявність типових елементів псоріазу остаточно підтверджує діагноз ювенільного ПсА.

Рідкісним для дитячого віку $є$ розвиток вісцеритів, які супроводжуються лихоманкою (інколи інтермітуючого характеру, з ознобом і проливним потом, що нагадуе картину сепсису), явищами інтоксикації, виснаженням, міозитами з вираженими міалгіями, розвитком міоатрофій. Розвиваються трофічні зміни придатків шкіри з утворенням трофічних виразок, пролежнів, посиленим випадінням волосся. Характерні лімфаденопатія, збільшення печінки з помірними порушеннями функціі; поліневрит, синдром Рейно, дифузний гломерулонефрит, ураження міокарда (міокардит, міокардіодистрофія), рідко - перикардит чи клапанні ураження; у поодиноких хворих (переважно в ANA-позитивних) - увеїт [3].

Принципи лікування ПсА в дітей ті самі, що в дорослих, із застосуванням нестероїдних протизапальних препаратів (перевага надається препаратам per os, оскільки ін'єкції можуть викликати місцеве загострення шкірного псоріазу - феномен Кюбнера), сульфасалазину (особливо при ураженні хребта), глюкокортикоїдів (внутрішньосуглобове введення, системне - при високій активності суглобового синдрому, розвитку вісцеритів, при ураженні шкіри за типом пустульозного псоріазу чи універсальної еритродермії), метотрексату. Хінолінові похідні (делагіл, плаквеніл) і купреніл не рекомендуються для лікування, оскільки часто викликають загострення шкірного процесу. Ефективними методами терапії тяжких, системних форм ПсА є плазмосорбція, поліензимотерапія (вобензим) [9].

Перебіг ПсА у дорослих затяжний з періодичними хвилями загострення, у дитячому віці менш агресивний: стійкої ремісії вдається досягнути у 20-50\% пацієнтів, хронічний артрит розвивається у $25 \%$, інвалідизація у 10\% хворих. За даними літератури, прогноз захворювання менш сприятливий у пацієнтів із первинним ураженням суглобів, у них частіше трапляються генералізовані форми ураження зі швидко прогресуючим перебігом i розвитком тяжкого ерозивного артриту. Фактори ризику тяжкого перебігу такі: значна кількість залучених у запальний процес суглобів, значне підвищення ШОЕ, поєднання ПсА зі спондилітом. Менш сприятливий прогноз захворювання при наявності вісцеритів, головним чином у зв'язку з можливим розвитком амілоїдозу [4].

Як приклад особливостей дебюту та діагностики ювенільного ПсА наводимо власне спостереження випадку захворювання 3 вираженими системними ураженнями і неспецифічними шкірними проявами псоріазу. Дівчинка Л., 13 років, уперше була госпіталізована на стаціонарне лікування в дитячу районну лікарню за місцем проживання в березні 2013 р. зі скаргами на лихоманку, загальну скутість, неможливість самостійно пересуватися у зв'язку з інтенсивним болем у суглобах, набряками кистей, наявністю висипань на обличчі, тулубі та кінцівках.

3 анамнезу хвороби відомо, що скарги на підвищення температури тіла до фебрильних цифр, біль і припухлість у суглобах, слабкість з'явились за 2 тижні до госпіталізації в клініку. Був встановлений діагноз ГРВІ, амбулаторно отримувала противірусну, антибактеріальну терапію. Незважаючи на проведене лікування, стан продовжував погіршуватися, через сильний біль у кінцівках дівчинка перестала самостійно пересуватися, у зв'язку з чим була госпіталізована в стаціонар за місцем проживання.

3 анамнезу відомо, що дитина народжена від першої вагітності, яка перебігала із загрозою переривання та кровотечею в терміні 9-12 тиж., з приводу чого мати лікувалася в стаціонарі. Пологи перші, термінові, фізіологічні. Маса тіла при народженні становила 4250 г, зріст -51 см. Дитина знаходилася на грудному вигодовуванні до 4,5 міс. Ранній анамнез - без особливостей, дівчинка росла та розвивалась відповідно до віку. Профілактичні щеплення проводились до даного захворювання. У п'ять років перенесла вітряну віспу. На харчову, побутову, медикаментозну алергію не страждала. Травм і операцій не було. Спадковість за ревматичними захворюваннями не обтяжена.

На момент госпіталізації у стаціонар за місцем проживання стан дитини був розцінений як тяжкий, обумовлений больовим, суглобовим, інтоксикаційним, гіпертермічним, шкірним синдромами. Самостійно не пересувалася, всі рухи різко болючі. Температура тіла $38,8^{\circ} \mathrm{C}$, артеріальний тиск (АТ) - 120/75 мм рт. ст. Дитина гіперстенічної тілобудови, задовільного харчування (вага - 65 кг, зріст - 157 см). Шкірні покриви бліді, на тулубі, верхніх і нижніх кінцівках, на обличчі відмічалися множинні плямисто-папульозні висипання рожевого кольору (фото 2, 3), екскоріації внаслідок вираженого свербежу шкіри. Променевозап'ясткові, п'ястно-фалан- 
гові суглоби кистей, колінні, гомілковостопні суглоби набряклі, спостерігалося локальне підвищення температури над вказаними суглобами, активні та пасивні рухи в них різко болючі. Болючість при рухах у шийному відділі хребта. Кисті рук набряклі. М'язовий тонус дещо знижений. Дихання через ніс вільне. Видимі слизові блідорожеві, чисті, піднебінні мигдалики гіпертрофовані до II ступеня. Язик обкладений білим нальотом, вологий. Пальпувалися передньошийні лімфовузли до 0,5-0,8 cм, еластичні, безболісні. У легенях вислуховувалося везикулярне дихання з обох боків, перкуторно без особливостей. Межі серця відповідали віковим нормативам. Тони серця задовільної звучності, тахікардія, що відповідає гіпертермії - 98-100 уд./хв, вислуховувався систолічний шум на верхівці серця. Зміни з боку травного тракту не виявлені. Фізіологічні відправлення не порушені.

При обстеженні в загальному аналізі крові анемії не було, відмічався лейкоцитоз - 19,8х106/л - 12,0х106/л 3 паличкоядерним зсувом, токсична зернистість нейтрофілів, підвищення ШОЕ до $46-19$ мм/год. Згортання крові не порушене. Біохімічний аналіз крові: загальний білок - 59-66 г/л, аланінамінотрансфераза (АЛТ) 19-50 MO/л, аспартатамінотрансфераза (АСТ) 25-46 МО/л, тимолова проба - 1-2 од., білірубін загальний - 8,0-8,6 мкмоль/л, КФК-МВ - 8,6 (норма до 25), сечовина - 3,96-6,64 ммоль/л, креатинін 0,062-0,067 ммоль/л. Гострофазові показники крові: РФ та антистрептолізин-о (АСЛ-О) негативні, С реактивний білок (СРБ) позитивний (48-6 мг/л). Аутоантитіла: LE-клітини не виявлені; антитіла до мітохондрій 13,638 од/мл (норма <10); антинуклеарні антитіла виявлені; антитіла до циклічного цитрулінованого пептиду 0,5 (норма <3); антитіла до дволанцюгової ДНК $1,4 \mathrm{IU} / \mathrm{ml}$, антитіла до одноланцюгової ДНК $-5,54 \mathrm{IU} / \mathrm{ml}$ (норма $<20$ ); антитіла до Јо-1 $-2,508$ (норма $<5,5$ ), циркулюючі імунні комплекси (ЦК) у межах норми. Аналізу крові на ієрсиніоз, псевдотуберкульоз, лептоспіроз негативний. Аналіз крові на Chlamydia pneumoniae (IgM) позитивний (13,96 за норми до 9,0). Аналіз крові на стерильність - немає росту. Загальний аналіз сечі, аналіз сечі за Нечипоренком без патології. В аналізі добової сечі білок не виявлений. Зішкріб на ентеробіоз негативний.

На електрокардіограмі (ЕКГ): ритм синусовий, правильний, частота серцевих скорочень (ЧСС) 100 уд./хв.; нормальне положення електричної вісі серця; прискорення атріовентрикулярної провідності, синдром ранньої реполяризації шлуночків.

Ехокардіографія (ЕхоКГ): порожнини серця в розмірах не збільшені, скороченість лівого шлуночка незначно знижена - фракція викиду - 57\%; пролапс мітрального клапана з мінімальною регургітацією; аортальний, тристулковий клапани, клапан легеневої артерії без особливостей.

Ультразвукове дослідження (УЗД) щитоподібної залози: топіка нормальна, додаткові утвори не виявлені, об'єм лівої долі - 2,8 см³, об'єм правої долі $-2,4 \mathrm{~cm}^{3}$, структура нормальна.

УЗД черевної порожнини: передньо-задній розмір правої долі печінки - 129 мм, ехоструктура однорідна; жовчний міхур із перегином у верхній третині, розмір - 62 мм, стінка нормальна, незначний застій; підшлункова залоза: розміри головки -26 мм, тіла -13 мм, хвоста -20 мм, ехоструктура неоднорідна, дифузні вогнища підвищеної ехогенності; селезінка розміром 94 мм, структура нормальна; нирки: топіка нормальна, права нирка розмірами 92х27 мм, ліва 93х28 мм, поодинокі мікроліти 1-2 мм з обох боків.
На рентгенограмі органів грудної клітки в прямій проекції патологія не виявлена.

Консультована ЛОР-лікарем (передній сухий риніт), неврологом (синдром вегетативної дисфункції).

Встановлений діагноз: Ювенільний ревматоїдний артрит, алергосептичний варіант, суглобово-вісцеральна форма з ураженням шкіри, поліартрит серонегативний, активність III ступеня, функиіональна недостатність (ФН) 0-I ступеня. Вторинна кардіоміопатія. Синусова тахікардія. Пролапс мітрального клапана I ступеня.

Отримане лікування: інфузійна терапія, дексаметазон (4 мг), метилпреднізолон (24 мг/добу), цефтріаксон, сумамед, кокарбоксилаза внутрішньом'язово, диклофенак натрію, панангін, флуконазол, верошпірон, небілет, анаприлін, метотрексат (15 мг/тиж.), фолієва кислота.

Рекомендації при виписці зі стаціонару: спостереження кардіоревматолога, окуліста, продовження прийому метотрексату (15 мг/тиж.), фолієвої кислоти, поступове зниження дози метилпреднізолону до повної відміни, прийом диклофенаку натрію, а при нападі тахікардії застосування анаприліну.

У клініко-діагностичне відділення ДУ «ППА НАМН України» дівчинка була госпіталізована в жовтні 2013 р. зі скаргами на періодичні артралгії, появу близько 1 місяця тому висипань на розгинальній поверхні ліктьових суглобів, періодичний біль у животі, цефалгії.

При госпіталізації в стаціонар стан дівчинки був відносно задовільний. Температура тіла $-36,8^{\circ} \mathrm{C}$. Дитина гіперстенічної тілобудови, кіфотична постава, задовільного харчування (вага -65 кг, зріст -158 см). Шкірні покриви бліді, помірний гіпереластоз, гіпергідроз кистей i стоп, рясні бляшкові висипання над ліктьовими суглобами. Видимі слизові блідо-рожеві, чисті, піднебінні мигдалики гіпертрофовані до II ступеня. Язик обкладений білим нальотом, рожевий, вологий. Зуби сановані. Периферичні лімфовузли не збільшені, еластичні, безболісні при пальпації. Суглоби в момент огляду не набряклі, не гарячі, активні та пасивні рухи у всіх групах суглобів у повному обсязі, безболісні. М'язовий тонус задовільний. У легенях вислуховувалося везикулярне дихання, перкуторно - ясний легеневий звук з обох боків. Межі відносної та абсолютної серцевої тупості відповідали віковій нормі. Тони серця ритмічні, задовільної звучності, вислуховувався м'який систолічний шум над лівими відділами серця, ЧСС -84 уд./хв. Артеріальний тиск $(\mathrm{AT})-110 / 65$ мм рт. ст. При пальпації живота відмічалася помірна болючість у ділянці епігастрію, правого підребер'я, міхурові симптоми негативні. Печінка та селезінка не збільшені. Симптом Пастернацького негативний з обох боків. Фізіологічні відправлення не порушені.

За даними лабораторно-інструментального обстеження:

Загальний аналіз крові: анемії не виявлено, лейкоцити $6,2 \times 10^{9} / л$, лейкоцитарна формула без особливостей, тромбоцити - 339х109/л, ШОЕ - 5 мм/год.

Протеїнограма: загальний білок - 69,7 г/л, альбуміни -

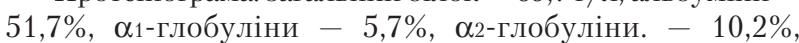
$\beta$-глобуліни - 14,0\%, $\gamma$-глобуліни $-18,4 \%$, альбуміноглобуліновий коефіцієнт $-1,07$.

Біохімічний аналіз крові: АЛТ - $14 \mathrm{MO} / л$, АСТ $20 \mathrm{MO} / л$, тимолова проба - 2,3 од., білірубін 7,2 мкмоль/л, сечовина - 4,76 ммоль/л, креатинін 0,092 ммоль/л, цукор - 4,01 ммоль/л.

Цукрова крива 3 харчовим навантаженням: глюкоза крові натщесерце - 3,76 ммоль/л, через 60 хв після навантаження $-4,78$ ммоль/л, через 120 хв - 3,56 ммоль/л. 
Гострофазові показники запалення: РФ, СРБ, АСЛ-О негативні.

Коагулограма: протромбіновий індекс - 67\%, час рекальцифікації - 100 с, фібриноген загальний 2,2 г/л, фібриноген $\beta(++)$.

Серологічне дослідження сироватки крові методом РНГА з псевдотуберкульозним, кишковоієрсиніозним діагностикумами негативне; реакція Райта і реакція Хеддельсона (бруцелльоз) негативні.

Імунограма: IgG - 11,8 г/л, IgA - 1,21 г/л, IgM 1,2 г/л, ЦІК - 0,041 од.; антинуклеарні антитіла, антифосфоліпідні антитіла, антитіла до одно- та дволанцюгової ДНК не виявлені; при дослідженні крові на HLA В27 результат негативний.

ЕКГ: синусовий ритм, ЧСС -76 уд./хв, вертикальне положення електричної вісі серця: 76 град., помірні обмінні зміни в міокарді. Комп'ютерна кардіоінтервалографія: виражене напруження адаптаційно-пристосувальних механізмів, вегетативна реактивність гіперсимпатикотонічна. ЕхоКГ: розміри порожнин серця не збільшені, гіпертрофії стінок немає, скороченість міокарда дещо знижена, регургітація на мітральному клапані.

УЗД органів черевної порожнини: жовчний міхур не збільшений, вигнутий у ділянці шийки, стінка ущільнена, не потовщена, вміст анехогенний, передньо-задній розмір правої долі - 122 мм, лівої - 50 мм, не збільшена, контури рівні, чіткі, ехогенність паренхіми не змінена, помірне ущільнення стінок внутрішньопечінкових жовчних ходів і судин системи портальної вени, портальна вена 7 мм, без особливостей; підшлункова залоза візуалізується повністю, розмірами $25 \times 17 \times 22$ мм, дифузно збільшена, ехогенність паренхіми незначно рівномірно підвищена, структура однорідна; селезінка не збільшена, структура без особливостей; нирки розташовані типово, не збільшені, ехогенність паренхіми обох нирок не змінена, чашково-мисочкова система помірно ущільнена.

УЗД щитоподібної залози: розташована в типовому місці, контури рівні, чіткі, капсула не ущільнена; ехогенність паренхіми не змінена, структура тканини однорідна; об'єм за Brunn правої долі $-4,2$ см³ $^{3}$, лівої долі -4 см³ $^{3}$ перешийок $-2,8$ мм, загальний об'єм - 8,2 см³ $^{3}$ (норма 8,6 $\mathrm{cm}^{3}$ ); регіонарні лімфовузли не збільшені.

На рентгенограмі кистей (рис. 3): зменшення просвіту всіх суглобових щілин суглобів кистей і променевозап'ясткових суглобів.

На фіброгастродуоденоскопії (ФГдС): езофагеальна ковзка кила стравохідного отвору; рефлюкс-езофагіт, катаральна гастропатія в стадії загострення, дуоденогастральний рефлюкс.

На езофагографії/скопії: стравохід прохідний, туго виповнюється контрастом, має правильну форму і будову; контраст вільно потрапляє в шлунок; кардія сходиться; гастро-езофагеальний рефлюкс не виявлений.

Бактеріальний посів із зіва на патологічну флору: рясний ріст Streptococcus viridans. Визначення антигенів респіраторних вірусів у слизу з носа методом флуоресцентної мікроскопії за COONS: виявлені антигени аденовірусу $(++)$ і вірусу парагрипу $(+++)$.

Аналіз сечі загальний і за Нечипоренком: без патологічних змін.

Копрограма: нейтральний жир (++), слиз у помірній кількості, виявлені яйця аскарид, реакція Грегерсена негативна.

Консультована дерматологом, вставлений діагноз: Псоріаз, бляшкова форма. Оглянута іншими спеціалістами: окулістом (visus OD/OS - 1,0; оптичні середовища, очне дно в нормі; передній відрізок очей не змінений), неврологом (вегетативна дисфункція, спадкова схильність, пубертатний період, цефалгіi), ендокринологом (ендокринної патології не виявлено), ЛОР-лікарем (без патологіi), ортопедом (кіфотична постава), хірургом (езофагеальна ковзка кила стравохідного отвору), дитячим гінекологом (дисменорея, пубертатна олігоменорея).

За анамнестичними і клініко-інструментальними даними: поліартрит тривалістю 7 міс. із залученням у дебюті захворювання міжфалангових і п'ястно-фалангових суглобів кистей («набряк кистей рук» у дебюті захворювання можна розцінити як специфічне «вісьове» ураження суглобів), променевозап'ясткових, колінних, гомілковостопних суглобів, даних рентгенографії суглобів (розвинуте звуження суглобових щілин всіх суглобів кистей і променевозап'ясткових суглобів), ураження шкіри у вигляді бляшок по розгинальній поверхні ліктьових суглобів, ознак ураження серця (за даними ЕКГ, ЕхоКГ), а також за медичними висновками спеціалістів дитині вставлено такий діагноз: Псоріатичний артрит, поліартритичний варіант, кардіоміопатія, бляшкове ураження шкіри в стадї регресії, активність 0-I ступеня, рентгенологічна стадія I, ФН-0. Вегетативна дисфункція, спадкова схильність, пубертатний період, цефалгії. Хронічний гастрит, стадія загострення. Дуодено-гастральний рефлюкс. Функиіональний розлад біліарної системи. Вторинна панкреатопатія. Дисменорея, пубертатна олігоменорея. Аскаридоз.

Отримане лікування: метотрексат (15 мг/тиж.), фолієва кислота (5 мг/тиж.), цинарикс, ескузан, кавінтон, гліцин, вермокс, ентеросгель, преднікарб на уражені ділянки шкіри, ароматерапія, масаж комірцевої зони, лікувальна фізкультура.

Рекомендації при виписці додому: диспансерне спостереження ревматолога, дерматолога, невролога, гастроентеролога, дитячого гінеколога; дотримання режиму дня, обмеження перегляду телепередач; дієта в межах стола № 5; продовження прийому: метотрексату (15 мг/тиж.), фолієвої кислоти, вобензиму, ескузану, кавінтону, гліцину, омезу, мотиліуму, вентеру; рекомендації дерматолога (аєвіт, кальцій Дз-Нікомед, епадол; місцево - преднікарб, карбодерм); рекомендації дитячого гінеколога (дисменорм); контроль ФГДС через 3 міс., контроль ЕхоКГ через 6 міс., масаж спини, лікувальна фізкультура.

Особливістю описаного випадку є розвиток у дівчинки-підлітка псоріатичного поліартриту із системними проявами (лихоманкою, міалгією, кардіопатією, високою активністю за даними лабораторного обстеження, у тому числі виявлення антинуклеарних аутоантитіл) на тлі атипових висипань (плямисто-папульозних на тулубі, верхніх і нижніх кінцівках та на обличчі) в дебюті захворювання, а також поява специфічних бляшкових уражень шкіри (спровокованих інсоляцією в літній період) лише через 6 міс. після дебюту хвороби. Такий перебіг ПсА ускладнив диференціальну діагностику з алергосептичним варіантом ЮІА, але суттєво не вплинув на ефективність лікування, оскільки тактика терапії при цих формах ураження суглобів багато в чому збігається.

Продемонстроване клінічне спостереження підтверджує доцільність при наявності суглобового синдрому, який супроводжується стійкими або рецидивними ураженнями шкіри, проведення диференційної діагностики $з$ ювенільним ПсА. Необхідне уточнення сімейного анамнезу (наявність випадків псоріазу у близьких родичів), виявлення уражень шкіри голови, складок шкіри, нігтів, слизової роту (з обов'язковою консультацією дерматолога), змін шкіри над ураженими суглобами 3 характерним синюшно-багровим відтінком кольору 
та/або ущільненням периартикулярних тканин, наявності різкого «морфінного» болю, ураження дистальних міжфалангових суглобів кистей, «вісьового ураження» пальців, сакроілеїту, визначення характерних рентгенологічних зміни (особливо в ділянці кінцевих фаланг, відсутність епіфізарного остеопорозу), виявлення антигену HLA-B27.

\section{ЛITЕРАТУРA}

1. Бунчук Н.В. Псориатический артрит: ревматология национальное руководство / Н.В. Бунчук, В.В. Бадокин, Т.В. Коротаева; под ред. Е.Л. Насонова, В.А. Насоновой. - М.: ГЭОТАР-Медиа, 2008. - С. 355-366.

2. Казимирко В.К. Ревматология: учебное пос. для врачей в вопросах и ответах / В.К. Казимирко, В.Н. Коваленко. - Донецк: Издатель Заславский, 2009. - С. 351-363.

3. Катеринчук І.П. Артралгія і артрити. Діагностика і лікування при ревматичних захворюваннях / І.П. Катеринчук, В.М. Жадан. Київ, 2007. - С. 88-89.

4. Псориаз и псориатический артрит / В. А. Молочков, В.В.Бадокин, В. И. Альбанова [и др.]. - М.: Тов-во научных изд. КМК; Авторская академия, 2007. -300 c.

5. Сизон О.О. Проблемні питання артропатичного псоріазу / О.О. Сизон, В.І. Степаненко // Здоровье Украины. - 2011. - № 1. - С. 13-30.
6. Сучасні можливості комплексної терапії хворих на класичні та атипові форми псоріазу / В.А. Бочаров, Н.Ю. Резніченко, О.В. Веретельник [та ін.] // Науковий вісник міжнар. гуманітарного університету. 2012. - № 3. - C. 11-24.

7. Чебышева С.Н. Псориатический артрит: руководство по детской ревматологии / С.Н. Чебышева; под ред. Н.А. Геппе, Н.С. Подчерняевой, Г.А. Лыскиной. - М.: ГЭОТАР-Медиа, 2011. - C. 285-299.

8. Clinical comparison of early-onset psoriatic and non-psoriatic oligoarticular juvenile idiopathic arthritis / M.L. Stoll, P.A. Nigrovic, A.C. Gotte, M. Punaro // Clin. Exp. Rheumatol. - 2011. - Vol. 23, № 2. - P. 50-55.

9. Juvenile psoriasis in European and Asian children: similarities and differences / L.Y. Chiam, M.E. de Jager, Y.G. Giam, E.M. de Jong // Br. J. Dermatol. - 2011. - Vol. 164, № 5. - P. 1101-1103.

\section{Особенности дебюта ювенильного псориатического артрита}

В.Б. Николаенко, Т.А. Полук, Л.И. Омельченко

ГУ «Институт педиатрии, акушерства и гинекологии НАМН Украины», г. Киев, Украина

Резюме. Статья посвящена проблемам диагностики псориатического артрита у детей в дебюте заболевания. Описаны особенности поражения кожи и суставов при различных клинических вариантах течения заболевания. Приведены наиболее информативные диагностические критерии ювенильного псориатического артрита. Представлен клинический случай ювенильного псориатического артрита с системным вариантом дебюта и атипичным поражением кожи.

Ключевые слова: ювенильный псориатический артрит, дебют, дети.

\section{PERINATOLOGIYA I PEDIATRIYA.2015.2(62):66-70;doi10.15574/PP.2015.62.66}

Features of juvenile psoriatic arthritis debut

V.B. Nikolaenko, T.A. Poluk, L.I. Omelchenko

SI «Institute of Pediatrics, Gynecology and Obstetrics NAMS of Ukraine», Kyiv, Ukraine

Summary. The article deals with the diagnostuc problems of psoriatic arthritis (PSA) debut in children. The features of skin and joints lesions in different clinical course of disease are described. The most informative diagnostic criteria for juvenile PsA are proposed. A clinical case of system debut of juvenile PsA with atypical skin lesions is represented.

Key words: juvenile psoriatic arthritis, debut, children.

\section{Сведения об авторах:}

Николаенко Виктория Борисовна - к.мед.н., ст.н.сотр. отделения болезней соединительной ткани у детей

ГУ «ИПАГ НАМН Украины». Адрес: г. Киев, ул. Майбороды, 8, тел. (044) 483-61-75.

Полук Тамара Анатольевна - к.мед.н., н.сотр. отделения болезней соединительной ткани у детей

ГУ «ИПАГ НАМН Украины». Адрес: г. Киев, ул. Майбороды, 8, тел. (044) 483-61-75.

Омельченко Людмила Ивановна - д.мед.н., проф., руководитель отделения болезней соединительной ткани у детей ГУ «ИПАГ НАМН Украины». Адрес: г. Киев, ул. Майбороды, 8, тел. (044) 483-61-75.

Статья поступила в редакцию 7.04.2015 г. 


\title{
С.0. Сокольник \\ Значення генеалогічного анамнезу в розвитку шлунково-кишкових кровотеч у дітей, хворих на виразкову хворобу
}

\author{
Буковинський державний медичний університет, м. Чернівці, Україна
}

\author{
PERINATOLOGIYA I PEDIATRIYA.2015.2(62):71-73;doi10.15574/PP.2015.62.71
}

Мета - проаналізувати генеалогічний анамнез у дітей Чернівецької області, хворих на ускладнену шлунково-кишковою кровотечею виразкову хворобу. Пацієнти та методи. Обстежено 78 дітей, хворих на ускладнену шлунково-кишковою кровотечею і неускладнену виразкову хворобу, та 50 здорових дітей віком 7-18 років, які проживають у Чернівецькій області та м. Чернівці. На основі вивчення генеалогічного анамнезу дитини розраховано генеалогічний індекс.

Результати. Ризик виникнення шлунково-кишкової кровотечі при виразковій хворобі зростає у 9,8 разу за наявності даного ускладнення в родичів пробанда. Високий показник генеалогічного індексу по виразковій хворобі в дитини можна розцінювати як предиктор виникнення кровотечі та ї̈ рецидиву. Висновки. У дітей із шлунково-кишковою кровотечею на фроні виразкової хвороби відмічається несприятливий генеалогічний анамнез. Вагомість обтяженого анамнезу у виникненні кровотечі зростає за наявності патології у двох родоводах.

Ключові слова: діти, шлунково-кишкова кровотеча, виразкова хвороба, генеалогічний анамнез, генеалогічний індекс.

\section{Вступ}

$\bigcirc$ дним із важливих факторів у формуванні здоров'я дитини є спостереження та контроль за його розвитком із метою раннього виявлення доклінічних станів та, у разі наявності захворювання, попередження розвитку ускладнень [4]. При цьому слід ураховувати на кожному етапі розвитку дитини дві групи факторів: ті, які зумовлюють здоров'я, і ті, які характеризують здоров'я. До першої групи належать фактори генеалогічного анамнезу, оскільки вони дають змогу прогнозувати ймовірність розвитку патології та визначати групу ризику [2]. Генеалогічний анамнез (збір родоводів) дає змогу прослідкувати ознаку або хворобу в родині із вказівкою на тип спорідненого зв'язку між членами родоводу.

Виразкова хвороба (BX) - генетично детерміноване, мультифакторне захворювання, у розвитку якого велике значення має генетична компонента, що зумовлює клінічну гетерогенність, варіантом якої є розвиток грізного ускладнення захворювання - шлунково-кишкової кровотечі (ШКК) [1], частота виникнення якої в дітей значно зростає останніми роками. Тому з метою виявлення нових факторів схильності до розвитку ШКК при ВХ у дітей перспективним є проведення ретельного генеалогічного аналізу [3, 5].

Mema роботи - проаналізувати генеалогічний анамнез у дітей Чернівецької області, хворих на ускладнену ШКК BX.

\section{Матеріали та методи дослідження}

Ретельне обстеження проведено в 78 дітей, хворих на ускладнену ШКК і неускладнену ВХ, та 50 здорових дітей віком 7-18 років, що проживають у Чернівецькій області та м. Чернівці (після підписання інформованої згоди на участь у дослідженнях). Групи спостереження репрезентативні за віком, статтю та місцем проживання ( $>0,05)$. Верифікація клінічного діагнозу проведена відповідно до протоколів лікування дітей за спеціальністю «Дитяча гастроентерологія». Ступінь тяжкості кровотечі та його стійкість оцінено за класифікацією Forrest S. A. et al. (1974 р., активна кровотеча (FIA, FIB); кровотеча, що відбулася (FIIA, FIIB, FIIC, FIII)) та показниками загального аналізу крові і коагулограми. Хворі діти розподілені на дві клінічні групи (КГ): I КГ (28 дітей) - пацієнти зі ШКК при ВХ різної активності та ступеня тяжкості, які знаходились на лікуванні в хірургічному (12 осіб із кровотечами FI, FIIA, FIIB) та гастроентерологічних (16 осіб без явних ознак кровотечі, однак при ендоскопіч- ному дослідженні діагностовано FIIB, FIIC, FIII; переважна більшість із них звернулася по медичну допомогу на 2-3-тю добу від моменту появи клінічних ознак захворювання) відділеннях дитячих лікарень м. Чернівці, II КГ (50 дітей) - хворі на неускладнену ВХ, які перебували на лікуванні в гастроентерологічних відділеннях лікарень міста.

3 метою виділення значущих факторів виникнення ШКК нами проведено анкетування дітей та їхніх батьків 3 аналізом стажу хвороби, частоти загострення, особливостей клінічного перебігу, наявності ускладнень, ефективності лікування. На основі результатів вивчення генеалогічного анамнезу дитини розраховано загальний генеалогічний індекс (ЗГІ) за патологією шлунковокишкового тракту (ШКТ) та спрямованість обтяженого генеалогічного анамнезу 3 розрахунком генеалогічного індексу (ГІ) за ВХ [2]. Результати дослідження статистично оброблені за допомогою пакетів комп'ютерних програм «Statistica» for Windows 8.0.0. (SPSS I.N.C.; 1989-1997), «STATISTICA V.6.0» (Stat Soft Inc; 1984-1996). Асоціації генеалогічного анамнезу зі схильністю до виникнення ШКК при ВХ оцінено за допомогою аналізу таблиць спряженості з розрахунком критерію $\chi^{2}(\mathrm{df}=1)$ та відношення шансів (ВШ) із використанням генотип-калькулятора.

\section{Результати дослідження та їх обговорення}

За результатами генеалогічного аналізу встановлено, що обтяжений сімейний анамнез по захворюваннях ШКТ спостерігався у 71,8\% дітей, хворих на ВX, що у 2,9 разу більше, ніж у групі здорових дітей, серед яких загальна спадковість за гастроентерологічною патологією становила 24,0\% (ВШ=8,06; ДI=3,57-18,21; $<0,01)$. Серед хворих дітей вірогідно частіше обтяжена спадковість діагностувалася в I КГ (89,3\%), ніж у II КГ $(62,0 \%)$, ВШ=5,11; ДІ=1,35-19,25; $<<0,05$.

У структурі патології ШКТ у родичів у групі хворих, на відміну від здорових, перше місце посіла ВX (51,8\% проти 8,3\%, p<0,01), друге - хронічний гастродуоденіт (26,8\% проти 8,3\%, p>0,05), третє - захворювання гепатобіліарної системи та підшлункової залози (17,8\% проти 50,0\%). Отже, за наявності BX у родичів дітей ризик розвитку патології зростає в 11,8 разу (ВШ=11,8; ДI=1,43-97,72; $<<0,01)$.

Порівняльний аналіз частоти ВХ у родоводі хворих з обтяженим анамнезом виявив вищий показник у пацієнтів I КГ, на відміну від II КГ (68,0\% проти 38,7\%, ВШ=3,37; ДI=1,11-10,19; p<0,05). У сім'ях 9 хворих (у $8(47,0 \%)$ 


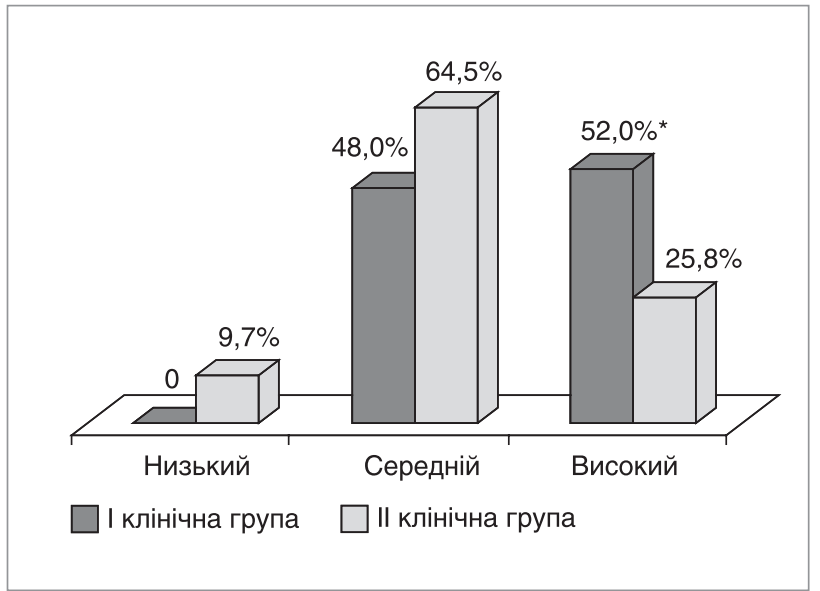

Примітка. * - різниця вірогідна щодо відповідного показника в осіб II клінічної групи, $p<0,05$.

Рис. 1. Показники загального генеалогічного індексу по захворюваннях шлунково-кишкового тракту у хворих дітей

I КГ та у $1(8,3)$ II КГ) був ускладнений ШКК перебіг ВX $(\mathrm{p} \varphi<0,05)$. Враховуючи зазначене, ризик розвитку ШКК у пробандів зростає у 9,8 разу (ВШ $=9,78 ;$ ДI=1,02-93,5; p $<0,05)$ за наявності в сім'ї ускладненої ШКК ВХ.

Аналіз характеру сімейної обтяженості у хворих дітей залежно від лінії успадкування показав переважання захворювань ШКТ по материнській лінії, ніж по батьківській $(57,1 \%$ та 23,2\%, p<0,05). Серед здорових осіб відмічалася така сама закономірність, хоча різниця не вірогідна (58,3\% та $41,7 \%, \mathrm{p}>0,05)$.

Необхідно зазначити важливість обтяженого анамнезу за двома лініями, який простежувався лише в родоводах хворих дітей $(19,6 \%)$ з переважанням у 3,3 разу в пацієнтів I КГ (p?<0,05). Наведені дані свідчать про зростання ризику реалізації патології ШКТ за наявності сімейної обтяженості за двома родоводами.

Слід зазначити, що серед родичів хворих дітей в обох КГ залежно від статі спостерігалося переважання в 1,8 разу хворих жіночої статі в пробандів - хлопчиків, і навпаки, чоловічої статі (в 1,3 разу) у пробандів - дівчаток.

У групі хворих дітей вірогідно частіше виявлялася обтяжена спадковість по захворюваннях ШКТ за двома i більше родичами, ніж у групі здорових $\left(\chi^{2=4,23, p<0,05}\right)$. Причому цей показник у групі дітей із неускладненою ВХ у 2,3 разу менший, ніж в осіб із ШКК $\left(\chi^{2=4,86, p<0,05}\right)$.

Виявлено позитивний кореляційний зв'язок між кількістю хворих із патологією ШКТ родичів і розвитком ВХ $(\mathrm{r}=0,54, \mathrm{p}<0,05)$ та кількістю хворих на ВХ родичів і виникненням ШКК $(\mathrm{r}=0,58, \mathrm{p}<0,05)$.

Для визначення ролі спадковості у виникненні ШКК при ВX визначалася загальна обтяженість анамнезу з розрахунком індексу обтяженості по захворюваннях ШКТ (ЗГІ) та направленість обтяженості генеалогічного анамнезу з розрахунком індексу обтяженості (ГІ) по ВХ.

У цілому по групі хворих дітей ЗГІ становив 0,72 , що характеризує його як несприятливий, тоді як у групі здорових $-0,24$, що розцінюється як сприятливий генеалогічний анамнез.

Несприятливий генеалогічний анамнез $(3 Г \mathrm{I} \geq 0,7)$ не відмічався в жодної здорової дитини, тоді як у групі хворих високі показники діагностувалися у 37,5\% осіб. У переважної більшості хворих на ВХ дітей обтяженість

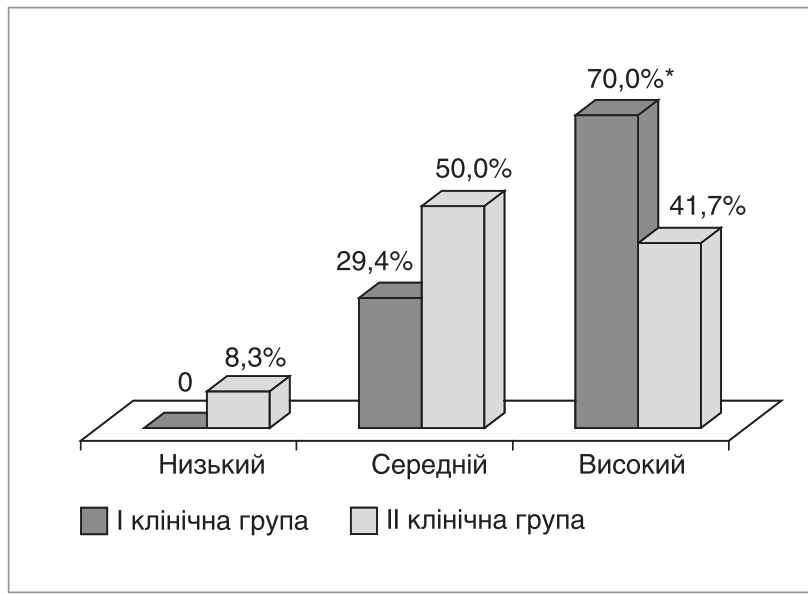

Примітка. * - різниця вірогідна щодо середнього значення генеалогічного індексу в осіб І клінічної групи, p<0,05. Pис. 2. Показники генеалогічного індексу по виразковій хворобі у хворих дітей

за патологією ШКТ знаходилась у межах середніх значень (ЗКІ=0,3-0,6), що розцінюється як умовно сприятливий анамнез. Цей показник у хворих в 1,7 разу вищий, ніж у групі здорових дітей (57,1\% проти 33,3\%, p>0,05).

Порівняльний аналіз показників ЗГІ по захворюваннях ШКТ між I та II КГ показав, що в дітей із ШКК низькі значення $(3 К \mathrm{I}<0,3)$ не виявлялися, тоді як у дітей II КГ вони спостерігалися у $9,7 \%$ осіб (рис. 1 ); середні значення дещо частіше діагностувалися в осіб II КГ (64,5\% проти 48,0\%, p $>0,05)$; високі показники ЗКІ з вірогідно вищою частотою виявлялися в I КГ (52\% проти $25,8 \%$ відповідно, р $<0,05)$.

Розраховано показники ГІ по ВХ у групах хворих дітей (рис. 2). У I КГ низькі значення ГІ по ВХ $(<0,1)$ не відмічалися в жодної дитини, середні $(0,1-0,3)$ - спостерігалися у $29,4 \%$ осіб, високі $(\geq 0,4)$ у 70,6\% пацієнтів; в осіб II КГ низькі значення ГІ по ВХ діагностувалися у 8,3\% хворих, середні - у 50,0\%, високі у 41,7\% пацієнтів. Отже, в дітей із ШКК у цілому генеалогічний анамнез по ВХ можна оцінити як несприятливий, тоді як у хворих на неускладнену ВХ як умовно сприятливий.

Таким чином, вивчення генеалогічного анамнезу дозволяє більш глибоко зрозуміти механізми патогенезу, розробити прогностичні критерії, поліпшити ефективність профілактики, визначити долю генетичних факторів у формуванні захворювання, а проведення аналізу в конкретному регіоні дасть змогу розробити регіональні програми індивідуального медико-соціального забезпечення населення.

\section{Висновки}

Аналіз генеалогічного дослідження дітей, хворих на ВХ неускладнену та ускладнену ШКК, показав, що предикторами реалізації кровотечі є наявність захворювання в родоводі, особливо за двома лініями, та обтяжений анамнез за двома й більше родичами. Високі показники загального генеалогічного індексу та його спрямованість по виразковій хворобі підвищують ризик виникнення ШКК у дитини, хворої на дану патологію.

Перспективи подальших досліджень

У подальшому необхідно провести комплексну оцінку стану здоров'я дітей із ШКК при ВХ із метою визначення найбільш значущих факторів ризику ускладненого перебігу захворювання. 


\section{ЛITEPATУРA}

1. Крылов Н.Н. Кровотечения их верхних отделов пищеварительного тракта: причины, факторы риска, диагностика, лечение / Н.Н. Крылов // Рос. журнал гастроэнтерол., гепатол., колопроктологии. 2011. - № 2. - С. 76-86.

2. Мачулина Л.Н. Комплексная оценка здоровья ребенка: метод. реком. / Л.Н. Мачулина. - Минск: Наука, 1999. - 52 с.

3. Перерва О.В. Вопросы прогнозирования рецидивов желудочно-кишечных кровотечений / О.В. Перерва, Б.А. Сот- ниченко, В.И. Макаров // Тихоокеанский мед. журнал. 2008. - № 4. - С. 87.

4. Резцова Е.Ю. Анализ генеалогического, акушерско-биологического и социального анамнезов дошкольников с речевыми нарушениями / Е.Ю. Резцова, А.М. Черных // Новые исследования. - 2010. T. 1, № 22. - С. 55-62.

5. Сацукевич В.Н. Факторы риска острых осложнений гастродуоденальных язв / В.Н. Сацукевич, Д.В. Сацукевич. - М.: Либерия, 2009. -416 с.

\section{Значение генеалогического анамнеза в развитии желудочно-кишечных кровотечений у детей с язвенной болезнью \\ С.А. Сокольник \\ Буковинский государственный медицинский университет, г. Черновцы, Украина}

Цель - проанализировать генеалогический анамнез у детей Черновицкой области с осложненной желудочно-кишечным кровотечением язвенной болезнью.

Пациенты и методы. Обследовано 78 детей с осложненной желудочно-кишечным кровотечением и неосложненной язвенной болезнью и 50 здоровых детей в возрасте 7-18 лет, проживающих в Черновицкой области и городе Черновцы. На основе изучения генеалогического анамнеза ребенка рассчитан генеалогический индекс.

Результаты. Риск возникновения желудочно-кишечного кровотечения при язвенной болезни увеличивается в 9,8 раза при наличии данного осложнения у родственников пробанда. Высокий показатель генеалогического индекса по язвенной болезни у ребенка можно расценивать как предиктор возникновения кровотечения и его рецидива.

Выводы. У детей с желудочно-кишечным кровотечением на фоне язвенной болезни наблюдается неблагоприятный генеалогический анамнез. Значение отягощенного анамнеза в развитии кровотечения увеличивается при наличии язвенной болезни в двух родословных.

Ключевые слова: дети, желудочно-кишечное кровотечение, язвенная болезнь, генеалогический анамнез, генеалогический индекс.

PERINATOLOGIYA I PEDIATRIYA.2015.2(62):71-73; doi10.15574/PP.2015.62.71

The value of the genealogical history in the development of gastrointestinal bleeding in children with peptic ulcer

S.0. Sokolnyk

Bukovinian State Medical University, Chernivtsi, Ukraine

Purpose - to analyze the genealogical history of the children of Chernivtsi region with complicated gastrointestinal bleeding ulcer.

Patients and methods. The study involved 78 children with complicated gastrointestinal bleeding and uncomplicated peptic ulcer disease and 50 healthy children aged 7-18 years living in Chernivtsi region and the city of Chernivtsi. On the basis of the genealogical history of the child is targeted genealogical index. Results. The risk of gastrointestinal bleeding with ulcers increase of 9.8 times in the presence of this complication with relatives of the proband. The high rate of the genealogical index of peptic ulcer in a child can be regarded as a predictor of bleeding and its recurrence.

Conclusion. Patients with gastrointestinal bleeding against the backdrop of a peptic ulcer is observed adverse genealogical history. Value laden history of bleeding is increased in the presence of peptic ulcer disease in the two lineages.

Key words: children, gastrointestinal bleeding, peptic ulcer, genealogical history, genealogical index.

Сведения об авторах:

Сокольник Сергей Александрович - к.мед.н., докторант, доц. каф. детской хирургии и отоларингологии Буковинского государственного медицинского университета. Адрес: г. Черновцы, ул. М. Пирогова, 26; e-mail: sers-doc@mail.ru.

Статья поступила в редакцию 20.04.2015 г. 


\title{
О.В. Тяжка1, А.О. Горобець1, В.В. Климчук1, Т.А. Богданова2, Л.О. Левадна1 Непереносимість глютена без целіакії: чи є привід замислитися?
}

\author{
1Національний медичний університет імені О.О. Богомольця, м. Київ, Україна \\ $2 Д 3$ «Дорожня клінічна лікарня № 1 станції Київ ДТГО «Південно-Західна залізниця», м. Київ, Україна \\ PERINATOLOGIYA I PEDIATRIYA.2015.2(62):74-76;doi10.15574/PP.2015.62.74
}

\begin{abstract}
Резюме. У статті висвітлюються питання новітніх тенденцій у сфері вивчення глютензалежних захворювань та їх впливу на життя людей. Зокрема, згадується популяризація, особливо в країнах заходу, безглютенового харчування та викликана нею прихильність великої кількості здорових людей аглютеновій дієті, що необґрунтовано та шкідливо. Описується непереносимість глютену без целіакії — одне 3 глютензалежних захворювань, що потребує ретельної диференційної діагностики з целіакією; наводяться особливості його клінічної картини, лабораторно-інструментальної та диференційної діагностики, звертається увага на необхідність вивчення патології в дітей України з огляду на відсутність таких досліджень у вітчизняній педіатричній практиці.
\end{abstract}

Ключові слова: діти, целіакія, глютензалежні захворювання, непереносимість глютена без целіакії.

$\mathrm{O}$ станнє десятиріччя в гастроентерології ознаменувалося стрімким зростанням глютензалежних захворювань і зумовленою ним модою на безглютенове харчування, яка впевнено набирає обертів переважно в західних країнах. Популяризація аглютенових продуктів, яка стала одним із сучасних трендів, що активно обговорюється в засобах масової інформації і відомим чи не в кожній родині, призвела до розповсюдження випадків, коли людина вдається до безглютенового харчування, тому що «це корисно» або ж «про всяк випадок» [12]. Чи виправдані такі тенденції і що собою являють глютензалежні захворювання, про які так жваво дискутує сьогодні науковий світ?

Більше ніж 100 років медицині відоме одне захворювання, пов'язане зі вживанням людиною глютенвмісних злаків, - целіакія. Целіакія, або глютенчутлива ентеропатія (хронічна імуноопосередкована хвороба тонкої кишки, що характеризується розвитком гіперрегенераторної атрофії слизової оболонки тонкої кишки у відповідь на введення глютену в генетично схильних осіб) описана англійським лікарем Samuel J. Gee у 1888 р., американським дослідником Herter C. у 1908 р. і німцем Heubner O.J.L. у 1909 р. $[3,4]$. Значний внесок у дослідження патології зроблено у 1950 р. голландським педіатром Dicke W.K., який пов'язав розвиток целіакії в дітей з токсичним впливом фракції пшеничного білка - гліадину. Поширеність глютенчутливої ентеропатії в популяції варіює у широких межах за даними різних досліджень - від 1:100 (Італія, Швеція, Ірландія, Австрія, США) до 1:3700 (Естонія, Німеччина) $[4,5]$. Проведені в останні роки скринінгові дослідження крові донорів на вміст антигліадинових антитіл із наступною ендоскопічною біопсією кишечнику встановили, що поширеність целіакії значно вища за загальновідомі показники і може сягати 1:80. Починаючи з середини XX ст. кількість нових випадків целіакії неухильно зростає. Так, за даними Rewers, 2005, якщо кількість діагностованих випадків захворювання у 1950-1959 рр. становила 0,2-0,5 на 100 тис. населення, то у 2000-2001 рр. цей показник сягнув 9-13 на 100 тис. населення [18]. 3 чим пов'язані високі темпи зростання рівня захворюваності на дану патологію: зі справжнім збільшенням кількості осіб, здатних розвивати ентеропатію у відповідь на вживання глютену, поліпшенням діагностики і широким впровадженням скринінгових програм чи наявністю патологічних станів, які помилково трактують як целіакію?

3 розвитком сучасної алергології на певному етапі стало зрозумілим, що білки злаків здатні викликати харчову алергію з розвитком інтестинальних симптомів, схожих на такі при глютенчутливій ентеропатії. I якщо діагностика даної патології рідко викликає труднощі через характерний для даної категорії пацієнтів ускладнений алергологічний анамнез (наявність алергічних захворювань у родичів дитини, «алергічний марш» тощо), яскраві дані «харчового щоденника», типові лабораторно-інструментальні зміни (еозинофілія у загальному аналізі крові, підвищення рівнів загального та специфічного (до білків злаків) IgE крові, еозинофільна інфільтрація слизової оболонки тонкої кишки), то виявлення іншого глютензалежного захворювання - непереносимості глютену без целіакії (НГБЦ) є більш складним і неоднозначним [6].

Протягом останніх років почастішали повідомлення про випадки, коли у відповідь на вживання пшениці і, меншою мірою, жита та ячменю, розвивались кишкові та позакишкові симптоми за відсутності діагностичних ознак целіакії або харчової алергії до білків злаків [6]. Ці повідомлення розпалили жваві дебати щодо можливого існування нового синдрому, який пізніше отримав назву непереносимості глютену без целіакії $[9,13,14]$. Глютен, основний білковий комплекс, що міститься в пшениці, житі, ячменю та полбі, визначено як пусковий фактор розвитку даного синдрому. У ході досліджень з'ясовано, що, крім глютену, інші білки злакових, такі як інгібітори амілази і трипсіну, можуть провокувати розвиток патології [23]. Останні дослідження акцентують увагу на можливу роль здатних до бродіння олігосахаридів, моносахаридів, дисахаридів і поліолів (FODMAPs) у розвитку НГБЦ [10]. Цікаво, що, крім молока, бобових, меду, деяких фруктів (кавун, вишня, манго, груша), овочів та зелені (цикорій, кріп, буряк, лук-порей), багатими джерелами FODMAPs є пшениця та жито, а також інші зернові, що містять протеїни глютену [17].

На сьогодні існує незначна кількість достатньо варіабельних даних, які дають змогу робити висновки щодо поширеності НГБЦ. Так, за даними обстеження 7762 осіб, проведеного за програмою «National Health and Nutrition Examination» у США в період 2009-2010 рр. [16], НГБЦ виявлено у 49 (0,6\%) випадках. Натомість за результатами дослідження, проведеного в Університеті Мериленду у 2004-2010 рр., НГБЦ діагностовано у 347 (6\%) із 5896 пацієнтів [19].

Що ж таке непереносимість глютену без целіакії? НГБЦ - це нове поняття, що витіснило такі терміни, як «непереносимість глютену», «гіперчутливість до глютену», «целіакоподібний синдром» тощо, які використовувалися у випадках, коли діагноз целіакії не підтверджувався. При цьому в пацієнта спостерігалися кишкові та/або позакишкові симптоми, розвиток яких був чітко зумовлений вживанням глютенвмісних продуктів, а виключення з раціону даних продуктів сприяло виразному клінічному поліпшенню $[2,11,22]$. Інші дослідники вважали, що термін «непереносимість глютену» лише маскує целіакію та інші патоло- 
гічні стани, не класифіковані на той момент (герпетиформний дерматит Дюринга, глютенова атаксія та алергія на злаки) і зумовлені вживанням глютену [2].

Пізніше поняття непереносимості глютену почали вживати для визначення малосимптомних станів, спровокованих вживанням глютенвмісних продуктів за відсутності в крові антитіл до тканинної трансглютамінази, антиендомізіальних антитіл, а також самої ентеропатії в осіб із варіабельними HLA-статусом і наявністю антигліадинових антитіл $[2,8,20]$

Таке розуміння проблеми значною мірою наближається до сучасного трактування НГБЦ як патологічного стану, пов'язаного з певними імунологічними, морфологічними і клінічними проявами непереносимості глютену в пацієнтів із виключеною целіакією. НГБЦ розвивається за власними неімунологічними та неалергічними механізмами, не має типової для целіакії ентеропатії (характерного ураження слизової оболонки тонкої кишки) і діагностується в осіб, які відзначають непереносимість злаків поліпшення самопочуття на тлі аглютенової дієти. Таким чином, НГБЦ припускається в дітей, в яких немає целіакії та алергії на пшеницю.

Оскільки проблема НГБЦ є достатньо новою, існує небагато досліджень, які дають змогу скласти чітке уявлення про патологію - iї клінічні особливості, перебіг, асоційованість з іншою патологію тощо.

Одним із найбільш масштабних спостережень, присвячених вивченню проблеми НГБЦ, стало дослідження, проведене в Італії протягом 2012-2013 рр. за участю 486 пацієнтів із діагнозом НГБЦ віком 3-81 рік [6]. $\mathrm{y}$ переважної більшості пацієнтів спостерігалося більше двох асоційованих кишкових або позакишкових симптомів (найбільш типові - метеоризм, абдомінальний біль (87 і 83\% відповідно), діарея (50\%), закрепи (24\%)). Іншими симптомами були епігастральний біль, нудота, аерофагія, печія. Найбільш частими позакишковими симптомами були слабкість, швидка втома, головний біль, дратівливість і відчуття оніміння кінцівок. Артралгії та/або міалгії констатовано у 31\% пацієнтів, втрату ваги - у 25\%, анемію (за рахунок дефіциту заліза та фолієвої кислоти) - у 22\%, депресію - у 18\%, дерматит у $18 \%$, шкірні (плямисті, плямисто-папульозні) висипання - у $29 \%$ обстежених.

У більше ніж половини обстежених патологічні симптоми маніфестували протягом 6 год. після вживання глютену, у 40\% випадків - через 6-24 год., у 10\% - пізніше ніж 24 год. У $90 \%$ випадків симптоми виникали за кілька місяців до того, як було припущено наявність НГБЦ. Серед найбільш типових захворювань, асоційованих із НГБЦ, були синдром подразненого кишечнику (47\%) і непереносимість лактози (35\%).

У 18\% пацієнтів виявлено целіакію серед родичів першого та другого рівня спорідненості. Носійство DQ2 визначено у $25 \%$ обстежених, DQ8 - у 8\%. Найбільш типовим серологічним маркером, виявленим у $25 \%$ пацієнтів із НГБЦ, були агліадинові антитіла (АГА) класу IgG, тоді як
АГА IgA, дезаміновані пептиди гліадину (ДПГ) IgG та ДПГ IgA визначено лише у 6\%, 6\% і 5\% відповідно.

За результатами гістологічного дослідження слизової оболонки дванадцятипалої кишки, зміни слизової оболонки Marsh 0 виявлено у 69\% пацієнтів і Marsh 1 - у 31\% відповідно до класифікації Marsh-Oberhuber [15].

Крім того, у 23\% випадків констатовано низький рівень ферритину, у 5\% - фолієвої кислоти, а в 11\% пацієнтів встановлено дефіцит вітаміну D [6].

Перші вітчизняні дослідження глютензалежних захворювань проведено під керівництвом Губської Е.Ю. у НМУ імені О.О. Богомольця. За результатами одного з таких досліджень, пацієнти з целіакією та НГБЦ мали низку подібних гастроентерологічних і позакишкових симптомів (діарею, абдомінальний біль, артралгії та міальгії, судоми, анемію), які не є специфічними і не дають змоги диференціювати целіакію та НГБЦ. Хворі на целіакію були серопозитивними за основними діагностичними біомаркерами целіакії (ТТГ і EMA), тоді як у хворих на НГБЦ ці маркери були негативними. Натомість високі титри AГA IgG виявлялися в пацієнтів обох груп. За результатами гістологічного дослідження, атрофія слизової оболонки дванадцятипалої кишки у пацієнтів із НГБЦ не визначалася, проте спостерігалася достовірно виразна інтраепітеліальна лімфоцитарна інфільтрація, яка, проте, не досягає рівня такої при целіакії [2].

Як відомо, хворі на целіакію потребують дотримання суворої пожиттєвої агліадинової дієти. Стосовно НГБЦ на сьогодні немає чітких рекомендацій щодо тривалості елімінаційної дієти. Необхідно проводити подальші дослідження, в яких слід визначити перелік токсичних злаків, допустимі порогові рівні вмісту глютену в продуктах харчування і тривалість дієтотерапії для осіб із НГБЦ [1].

За даними досліджень, кількість людей, які вдаються до безглютенового харчування, значно перевищує кількість хворих на НГБЦ [6]. Так, відомо, що близько 5\% населення Нової Зеландії (включаючи дитячу популяцію) уникають вживання глютенвмісних продуктів за відсутності будь-яких клінічних ознак непереносимості глютену [12]. За іншими даними, у 30\% людей, які самостійно вирішили виключити глютен із раціону харчування, виявлено такі захворювання, як синдром надмірного бактеріального росту у тонкому кишечнику, непереносимість лактози або фруктози, мікроскопічний коліт, парез шлунка і спазм тазового дна [7].

На сьогодні в Україні немає досліджень, присвячених вивченню проблеми глютензалежних захворювань у педіатрії. 3 огляду на те, що питання диференційної діагностики глютенчутливої ентеропатії з непереносимістю глютену без целіакії є надзвичайно актуальним через відмінності в перебігу, виразності уражень слизової оболонки тонкої кишки, дієтотерапії і прогнозі обох захворювань, слід акцентувати увагу педіатрів на необхідності ретельної діагностики із залученням гістологічних, серологічних і генетичних методів дослідження з метою правильної постановки діагнозу і уникнення необгрунтованого призначення аглютенової дієти, яка може позбавити дитину необхідних нутрієнтів і вітамінів, що містяться в злаках.

\section{ЛIТЕРАТУРА}

1. Губская Е.Ю. Новое понимание спектра глютензависимых заболеваний / Е.Ю. Губская // Сучасна гастроентерологія. 2014. - № 1 (75). - С. 160-164.

2. Губская Е.Ю. Особенности диагностики непереносимости глютена без целиакии / Е.Ю. Губская, А.А. Шевчик // Гастроэнтерология. 2014. - № 2. - C. 24-25.
3. Клинические аспекты целиакии у детей: пос. для практических врачей-педиатров / Н.А. Коровина, И.Н. Захарова, Ю.А. Лысиков [и др.]. - М.: МедЭкспертПресс, 2007. - 79 с.

4. Майданник В.Г. Болезни органов пищеварения у детей / В.Г. Майданник. - Київ: СП «Інтертехнодрук», 2010. C. 811-887. 
5. Adult celiac disease: prevalence and clinical significance / H.B. Cook, M.J. Burt, J.A. Collet [et al.] // J. Gastroenterol. Hepatol. - 2000. № 15. - P. 1032-1036

6. An Italian prospective multicenter survey on patients suspected of having non-celiac gluten sensitivity / U. Volta, M.T. Bardella, A. Calabr [et al.] // BMC Medicine. - 2014. - № 12. - P. 85.

7. Characteristics of patients who avoid wheat and/or gluten in the absence of celiac disease / A. Tavakkoli, S. Lewis, C. Tennyson [et al.] // Dig. Dis. Sci. - 2013.

8. Cutting-edge issues in celiac disease and in gluten intolerance / N. Bizzaro, R. Tozzoli, D. Villalta [et al.] // Clin. Rev. Allergy Immunol. Published online first: 23 December, 2010.

9. Di Sabatino A. Nonceliac gluten sensitivity: sense or sensibility? / A. Di Sabatino, G. Corazza // Ann. Intern. Med. - 2012. № 156. - P. 309-311.

10. Gibson P. Food choice as a key management strategy for functional gastrointestinal symptoms / P. Gibson, S. Sheperd // Am. J. Gastroenterol. - 2012. - № 107. - P. 657-666.

11. Gluten intolerance: gender- and age-related differences in symptoms / M. Bardella, C. Fradella, V. Saladino [et al.] // Scand. J. Gastroenterol. - 2005. - Vol. 40. - P. 15-19.

12. New Zealand Asthma and Allergy Cohort Study Group. Coeliac disease and gluten avoidance in New Zealand children / P. Tanpowpong, T. Ingham, P. Lampshire [et al.] // Arch. Dis. Child. - 2012. № 97. - P. 12-16.

13. Non-celiac gluten sensitivity: questions still to be answered despite increasing awareness / U. Volta, G. Caio, F. Tovoli, R. De Giorgio // Cell. Mol. Immunol. - 2013. - № 10. - P. 383-392.

14. Non-celiac gluten sensitivity: the new frontier of gluten related disorders / C. Catassi, J. Bai, B. Bonaz [et al.] // Nutrients. - 2013. № 5. - P. 3839-3853.
15. Oberhuber $\mathrm{G}$. The histopathology of coeliac disease: time for a standardized report scheme for pathologists / G. Oberhuber, G. Granditsch, H. Vogelsang // Eur. J. Gastroenterol. Hepatol. 1999. - Vol. 11. - P. 1185-1194.

16. Prevalence of gluten-free diet adherence among individuals without celiac disease in the USA: results from the Continuous National Health and Nutrition Examination Survey / D. DiGiacomo, C. Tennyson, P. Green, R. Demmer // Scand. J. Gastroenterol. - 2013. № 48. - P. 921-925.

17. Quantification of fructans, galacto-oligosacharides and other short-chain carbohydrates in processed grains and cereals / J. Biesiekierski, O. Rosella, R. Rose [et al.] // J. Hum. Nutr. Diet. - 2011. № 24. - P. 154-176.

18. Rewers M. Epidemiology of celiac disease: What are the prevalence, incidence and progression of the celiac disease? / M. Rewers // Gastroenterology. - 2005. - № 128. P. 47-51.

19. Spectrum of gluten-related disorders: consensus on new nomenclature and classification / A. Sapone, J. Bai, C. Ciacci [et al.] // BMC Med. - 2012. - № 10. - P. 13.

20. Troncone R. Coeliac disease and gluten sensitivity / R. Troncone, B. Jabri // J. Intern. Med. - 2011. - Vol. 269. P. 582-590.

21. Verdu E. Between celiac disease and irritable bowel syndrome E. Verdu, D. Armstrong, J. Murray // Am. J. Gastroenterol. - 2009. № 104. - P. 587-1594.

22. Walker-Smith J. Transient gluten intolerance / J. Walker-Smith // Arch. Dis. Child. - 1996. - Vol. 74. - P. 183.

23. Wheat amylase trypsin inhibitors drive intestinal inflammation via activation of toll-like receptor 4 / Y. Junker, S. Zeissig, S. Kim [et al.] // J. Exp. Med. - 2012. - № 209. - P. 2395-2408.

\section{Непереносимость глютена без целиакии: есть ли повод задуматься?}

А.В. Тяжкая1, А.А. Горобец1, В.В. Климчук1, Т.А. Богданова2, Л.А. Левадная

2Национальный медицинский университет имени А.А. Богомольца, г. Киев, Украина

1ГУ «Дорожная клиническая больница № 1 станции Киев ДТГО «Южно-Западная железная дорога», г. Киев, Украина

Резюме. В статье освещаются вопросы новых тенденций в сфере изучения глютензависимых заболеваний и их влияния на жизнь людей. В частности, упоминается популяризация, особенно в западных странах, безглютенового питания и вызванная ей приверженность большого числа здоровых людей аглютеновой диете, что является необоснованным и вредным. Описывается непереносимость глютена без целиакии - одно из глютензависимых заболеваний, нуждающееся в тщательной дифференциальной диагностике с целиакией; приводятся особенности его клинической картины, лабораторно-инструментальной и дифференциальной диагностики, обращается внимание на необходимость изучения патологии у детей Украины в виду отсутствия таких исследований в отечественной педиатрической практике.

Ключевые слова: дети, целиакия, глютензависимые заболевания, непереносимость глютена без целиакии.

\section{PERINATOLOGIYA I PEDIATRIYA.2015.2(62):74-76; doi10.15574/PP.2015.62.74}

Non-celiac gluten sensitivity: is there any reason to worry about?

O.V. Tiazhka1, A. O. Gorobets1, V.V. Klimchuck1, T.A. Bogdanova2, L.O. Levadna1

1 Natsionalny Medical University named after AA Bogomolets, Kyiv, Ukraine

2 GU «Road Clinical Hospital № 1 station Kiev DTGO» «South-Western Railway», Kiev, Ukraine

Summary. The problems of modern tendencies in gluten related disorders study and their influence upon people's life are reflected in the article. In particular, popularization of gluten free diet (spreading in western countries mainly) and adherence of great number of healthy people to this causeless and, sometimes, harmful habit is discussed. Non-celiac gluten sensitivity — one of gluten related disorders, requiring thorough differential diagnostics with celiac disease is described; peculiarities of its clinical picture, laboratory-and-instrumental and differential diagnostic are depicted. Special attention is paid on the necessity of non-celiac gluten sensitivity study among children's population in Ukraine due to the absence of such studies in pediatric practice of our country.

Key words: children, celiac disease, gluten related disorders, non-celiac gluten sensitivity.

Сведения об авторах:

Тяжкая Александра Васильевна - д.мед.н., проф., зав. каф. педиатрии №1 НМУ

им. А.А. Богомольца. Адрес: г. Киев, ул. М. Коцюбинского, 8А; тел. (044) 465-17-88; e-mail: pediatrics1@mail.ru.

Горобец Анастасия Александровна - к.мед.н., доц. каф. педиатрии № 1 НМУ им. А.А.Богомольца, гУ «Дорожная

клиническая больница № 1, ст. Киев» ГТГО «Юго-Западная железная дорога». Тел. (044) 465-17-89.

Климчук В.В. - каф. педиатрии № 1 НМУ им. А.А.Богомольца, ГУ «Дорожная клиническая больница № 1 ,

ст. Киев» ГТГО «Юго-Западная железная дорога». Тел. (044) 465-17-89.

Богданова Т.А. - каф. педиатрии № 1 НМУ им. А.А.Богомольца, ГУ «Дорожная клиническая больница № 1 ,

ст. Киев» ГТГО «Юго-Западная железная дорога». Тел. (044) 465-17-89.

Левадная Людмила Александровна - к.мед.н., доц. каф. педиатрии №1 НМУ им. А.А. Богомольца.

Адрес: г. Киев, ул. М. Коцюбинского, 8а; тел. (044) 465-17-89.

Статья поступила в редакцию 30.04.2015 г. 


\title{
Б.А. Тарасюк 1, И.В. Андрущенко1, И.С. Лукьянова2 2 Ультразвуковые проявления аутосомно-рециссивной поликистозной болезни почек у детей
}

1ГУ «Институт ядерной медицины и лучевой диагностики НАМН Украины», г. Киев, Украина 2ГУ «Институт педиатрии, акушерства и гинекологии НАМН», г. Киев, Украина

\author{
PERINATOLOGIYA I PEDIATRIYA.2015.2(62):77-80;doi10.15574/PP.2015.62.77
}

Цель - оценить результаты комплексного эхографического исследования почек и печени у детей с аутосомно-рециссивной поликистозной болезнью почек.

Пациенты и методы. Обследовано 9 детей с данной патологией в возрасте от 3 до 16 лет. Средний возраст составил 6,2ะ2,3 года. Мальчиков было 7, девочек - 2. Сонографическое исследование проведено согласно стандартным протоколам на аппаратах Acuson X300 (Siemens, Германия), MyLab Class C (ESAOTE, Италия). Использованы мультичастотные конвексные 2-5 МГц. С целью детального изучения паренхимы почек и печени использовано высокочастотное сканирование датчиками 10 МГц.

Результаты. При эхографическом исследовании во всех случаях выявлено сочетанное поражение почек и печени. При эхогепатографии изменения в печени укладывались в картину фриброзных изменений разной степени выраженности. У всех пациентов поражение почек было двухсторонним, размеры почек были больше возрастных показателей от 50 до 75\%. Контуры почек были ровными, четкими. Дифференциация паренхиматозного слоя и чашечно-лоханочной системы практически не определялась.

Выводы. Во всех наблюдениях при комплексном эхографическом исследовании обнаружены структурные изменения в почках и печени, а также изменения показателей регионарного почечного и печеночного кровотока.

Ключевые слова: аутосомно-рецессивная поликистозная болезнь почек, врожденный фиброз печени, дети, эхографическое исследование.

\section{Введение}

утосомно-рецессивная поликистозная болезнь Апочек (АРПКБП) является сложным наследственным хроническим заболеванием почек у детей, которое обычно курируется нефрологами. Однако мультисистемность поражения требует выработки оптимальной тактики лечения с привлечением разнопрофильных специалистов, в том числе и гастроэнтерологов. Наиболее часто у пациентов с АРПКБП наблюдаются симптомы врожденного фиброза печени (ВФП), с последующим развитием портальной гипертензии. Известно, что еще пренатально может быть высказано предположение о АРПКБП у плода на основании признаков маловодия, наличия увеличения размеров почек и повышения их эхогенности. Неонатологи первыми сталкиваются с такими новорожденными у которых может быть не только массивное увеличение почек, но и гипоплазия легких. В последующем пациенты с АРПКБП наблюдаются урологами и трансплантологами, поскольку при значительном увеличении почек возможно проведение нефректомии для уменьшения масс-эффекта, подготовка пациентов к диализу и последующей трансплантации органа. Очень важным аспектом для семей, где выявлено АРПКБП, является меди- ко-генетическое консультирование при планировании последующих беременностей [5].

Установлено, что причиной заболевания является мутация гена PKHD1 «polycystic kidney and hepatic disease 1» (6 хромосома, позиция 12.2), отвечающего за синтез белка фиброцистина, присутствующего в норме в почках (собирательные трубочки и нисходящая часть петли Генле), печени (эпителий желчных протоков) и поджелудочной железе [2, 9, 10].

Впервые АРПКБП описана как особая форма поликистоза почек в 1902 г. В 1947 г. Lambert P. опубликовал работу о гистотопографическом и функциональном состоянии кистозно измененных нефронов и высказал положение о кистозно измененном нефроне как функционирующей единице почки [6]. В 1964 г. Osathanondh V. и Potter E. [7, 8] классифицировали АРПКБП как 1-й тип кистозной болезни почек. B 1971 г. Blythe Н. и Ockenden B. [1] выделили четыре клинико-морфологические формы АРПКБП - перинатальную, неонатальную, инфантильную и ювенильную - в зависимости от процентного поражения канальцевого аппарата почек.

B 1973 г. Thaler M. et al. [3] высказали предположение о том, что АРПКБП и ВФП - это единая болезнь, в осно-

Классификация кистозных заболеваний почек [4]

Таблица Генетические

\begin{tabular}{|c|c|c|c|}
\hline \multicolumn{3}{|c|}{ Генетические } & \multirow[b]{2}{*}{ Негенетические } \\
\hline $\begin{array}{l}\text { Аутосомно- } \\
\text { рецессивные }\end{array}$ & $\begin{array}{l}\text { Аутосомно- } \\
\text { доминантные }\end{array}$ & $\begin{array}{c}\text { Кисты ассоциированные } \\
\text { с синдромами }\end{array}$ & \\
\hline $\begin{array}{c}\text { Аутосомно-рецессивная } \\
\text { поликистозная болезнь } \\
\text { почек (АРПКБП) }\end{array}$ & $\begin{array}{c}\text { Аутосомно-доминантная } \\
\text { поликистозная } \\
\text { болезнь почек (АДПКБП) }\end{array}$ & $\begin{array}{c}\text { Аутосомно- } \\
\text { рецессивный синдром }\end{array}$ & $\begin{array}{l}\text { Кистозная дисплазия } \\
\text { или дисплазия почек }\end{array}$ \\
\hline $\begin{array}{l}\text { Ювенильный } \\
\text { нефрофтиз }\end{array}$ & $\begin{array}{c}\text { Туберозный } \\
\text { склероз }\end{array}$ & $\begin{array}{c}\text { Синдром, связанный } \\
\text { с X-хромосомой }\end{array}$ & Поликистозная дисплазия почек \\
\hline & Медуллярная болезнь почек & Хромосомные нарушения & Губчатая медуллярная почка \\
\hline & \multirow{5}{*}{$\begin{array}{c}\text { Гломерулокистозная } \\
\text { болезнь почек }\end{array}$} & & $\begin{array}{c}\text { Локализованная } \\
\text { кистозная болезнь почек }\end{array}$ \\
\hline & & & Простые кисты \\
\hline & & & Поликистоз почек \\
\hline & & & Опухоль Вильмса \\
\hline & & & $\begin{array}{c}\text { Приобретенные кисты } \\
\text { почек (при хронической почечной } \\
\text { недостаточности) }\end{array}$ \\
\hline
\end{tabular}




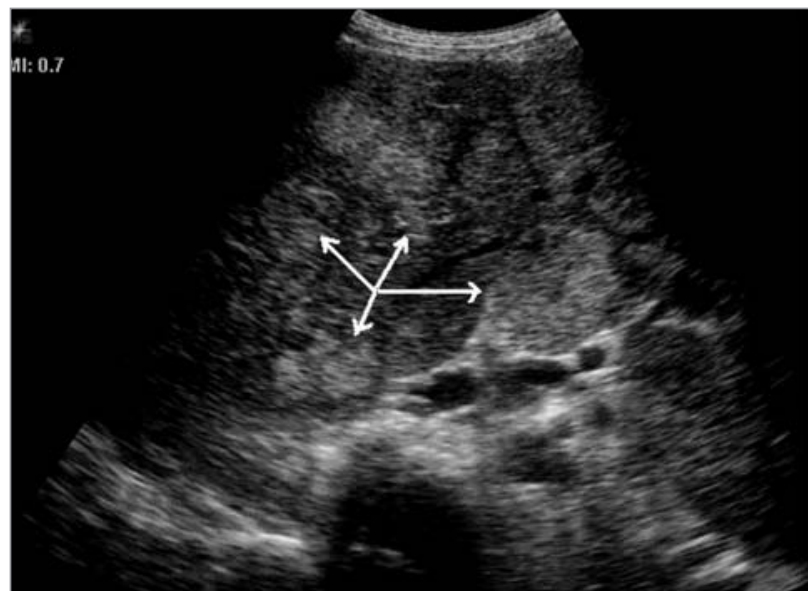

Pис. 1. Эхограмма печени ребенка 5 лет. Датчик 5 МГц (стрелками обозначены участки фриброза в печени)

ве которой лежит нарушение эмбрионального развития соединительной ткани.

Из всех почечных кистозных болезней АРПКБП является самой частой наследственной болезнью с манифестацией в младенчестве и детском возрасте. Частота АРПКБП колеблется от 1 на 20000 до 1 на 40 000, а частота гетерозиготных носителей - как 1 к 70.

Кистозные поражения почек делятся на генетические и негенетические, что имеет определенное значение в плане проведения дифференциальной диагностики. Более подробные сведения представлены в таблице.

Заболевание проявляется хронической рецидивирующей пиурией, которая может отмечаться уже в раннем детском возрасте. Наличие эктазий канальцев предрасполагает к образованию камней, что проявляется почечными коликами и гематурией. Течение длительное. Расширенные собирательные канальцы и фиброз (в тяжелых случаях) может значительно нарушить функцию почек и вызывать гипертензию и почечную недостаточность. ВФП характеризуется прогрессивным развитием портальной гипертензии и возникновением желудочных кровотечений.

Таким образом, АРПКБП - это генетическое, фенотипически разнообразное заболевание, которое характеризуется двумя наиболее типичными проявлениями: прогрессирующей дистрофией почечных канальцев с развитием множественных эктазий дистальных извитых и собирательных канальцев, а также ВФП. В некоторых случаях может сочетаться с кистозным фиброзом поджелудочной железы и кистами легких.

В настоящее время визуальная диагностика АРПКБП в основном осуществляется ультразвуковым методом. Эхография позволяет проводить комплексный динамический мониторинг за состоянием почек и печени. В то же время, метод экскреторной урографии, основной метод диагностики заболеваний почек в течение последних 70 лет, уже не используется и представляет исторический интерес.

Цель работы - оценить результаты комплексного эхографического исследования почек и печени у детей с АРПКБП.

\section{Материалы и методы исследования}

Обследовано 9 детей с АРПКБП в возрасте от 3 до 16 лет. Средний возраст составил $6,2 \pm 2,3$ года. Мальчиков

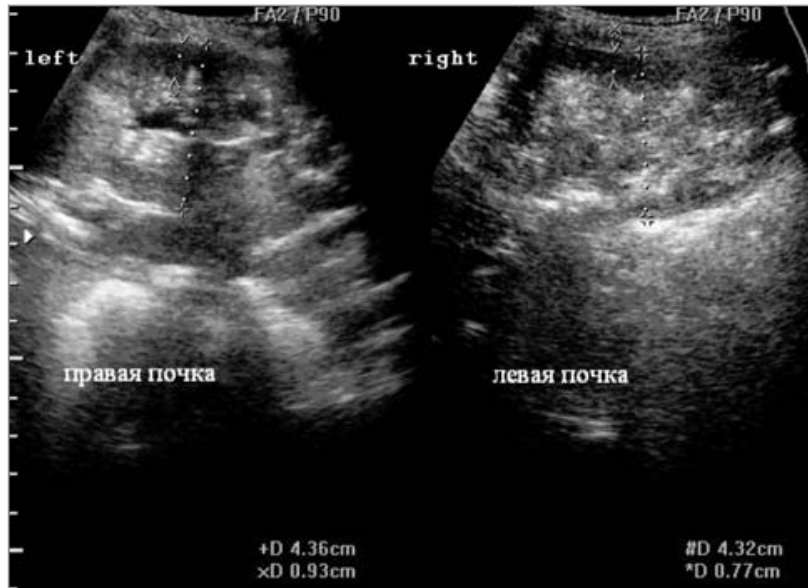

Pис. 2. Эхограмма почек ребенка 5 лет. Аутосомно-рецессивная поликистозная болезнь почек

было 7, девочек - 2. Сонографическое исследование проведено согласно стандартным протоколам на аппаратах Acuson X300 (Siemens, Германия), MyLab Class C (ESAOTE, Италия). Использованы мультичастотные конвексные 2-5 МГц. С целью детального изучения паренхимы почек и печени использовано высокочастотное сканирование датчиками 10 МГц.

\section{Результаты исследования и их обсуждение}

При эхографическом исследовании во всех случаях выявлялось сочетанное поражение почек и печени. При

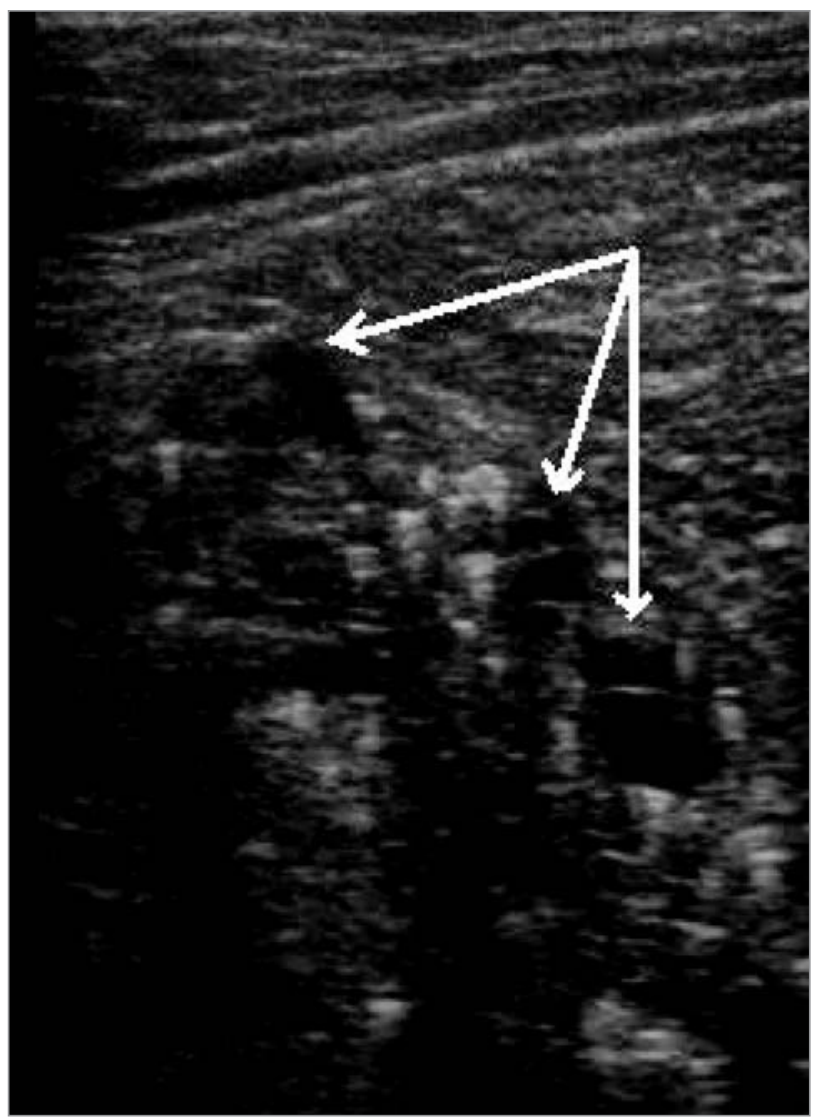

Pис. 3. Эхограмма правой почки у ребенка 6 лет. Датчик 10 МГц (стрелками обозначены микрокисты почечной паренхимы) 
эхогепатографии изменения в печени укладывались в картину фиброзных изменений разной степени выраженности. При этом отмечалось значительное неоднородное повышение эхогенности паренхимы органа, наличие уплотнения стенок сосудов портальной системы, утолщение и уплотнение глиссоновой капсулы (рис. 1).

Степень фибротических изменений в печени преимущественно зависела от возраста пациентов. При допплерографическом исследовании выявлялось повышение индекса резистентности в собственной печеночной артерии до 0,73-0,79. Следует отметить, что во всех наблюдениях при поражении печени регистрировался однофазный (портализированный) кровоток в правой печеночной вене и ее более мелких разветвлениях, что свидетельствовало о повышении плотности печеночной паренхимы У 4 пациентов регистрировались ультразвуковые признаки портальной гипертензии, а именно: увеличение диаметра портальной вены, реканализация пупочной вены, снижение скорости кровотока в портальной вене $(11,2 \pm 2,3 \mathrm{~cm} / \mathrm{c})$, значительное увеличение размеров селезенки $(14,8 \pm 2,7$ см на $5,3 \pm 2,2$ см), увеличение диаметра селезеночной вены. При проведении эндоскопического исследования пищевода, желудка и двенадцатиперстной кишки у этих пациентов выявлялись признаки расширения вен в нижней трети пищевода.

У всех пациентов поражение почек было двухсторонним. При этом размеры почек были больше возрастных показателей от 50 до 75\%. Контуры почек были ровными, четкими. Дифференциация паренхиматозного слоя и чашечно-лоханочной системы практически не опреде- лялась. Признаки гидронефроза отсутствовали. Почечная паренхима была значительно повышенной эхогенности, умеренно неоднородной структуры (рис. 2).

На этом фоне визуализировалось большое количество мелких кальцинатов диаметром 1-2 мм. Следует отметить, что при использовании высокочастотных датчиков дополнительно регистрировалось наличие мелких (иногда неправильной формы) кист диаметром 1-4 мм с тонкими стенками и акустически прозрачным содержимым (рис. 3).

Васкуляризация почечной паренхимы не была нарушена, а при исследовании аркуатных артерий индекс резистентности колебался от 0,47 до 0,57 .

\section{Выводы}

Таким образом, во всех наблюдениях при комплексном эхографическом исследовании обнаруживались структурные изменения в почках и печени, а также изменения показателей регионарного почечного и печеночного кровотока.

Ультразвуковое исследование паренхиматозных органов при АРПКБП является высокоинформативной составляющей алгоритма обследования пациентов с данной патологией. Метод позволяет проводить динамическое обследование пациентов с целью своевременного выявления осложнений со стороны печени, в частности, портальной гипертензии.

В случае обнаружения у детей ультразвуковых признаков АРПКБП показана консультация медицинского генетика, нефролога и гастроэнтеролога.

\section{ЛИТЕРАТУРА}

1. Blythe H. Polycystic Disease of Kidneys and Liver Presenting in Childhood / H. Blythe, B. Ockenden // J. of Med. Genetics. - 1971. № 8. - P. 257-284.

2. Cellular and subcellular localization of the ARPKD protein; fibrocystin is expressed on primary cilia / C. J. Ward, D. Yuan, T. V. Masyuk [et al.] // Hum. Mol. Genet. - 2003. - Vol. 12, № 20. - P. 2703-2710.

3. Congenital fibrosis and polycystic disease of liver and kidneys / M. M. Thaler, E. S. Ogata, J. R. Goodman [et al.] // Am. J. Dis. Child. 1973. - Vol. 126. - P. 374-380.

4. De Bruyn R. Imaging in cystic renal disease / R. de Bruyn, I. Gordon // Arch. Dis. Child. - 2000. - Vol. 83. - P. 401-407.

5. Hartung E. A. Autosomal Recessive Polycystic Kidney Disease: A Hepatorenal Fibrocystic DisorderWith Pleiotropic Effects / E. A. Hartung, L. M. Guay-Woodford // Pediatrics. - 2014. - Vol. 134, № 3. P. 833-845.

6. Lambert P. Polycystic disease of the kidney / P. Lambert // Arch. Pathol. 1947. - Vol. 44. - P. 34-58.

7. Osathanondh V. Pathogenesis of polycystic kidneys: historical survey / V. Osathanondh, E. Potter // Arch. Pathol. - 1964. - Vol. 77. P. 459-465.

8. Osathanondh V. Pathogenesis of polycystic kidneys: type I due to hyperplasia of interstitial portions of collecting tubules / V. Osathanondh, E. Potter // Arch. Pathol. - 1964. - Vol. 77. - P. 466-473.

9. The gene mutated in autosomal recessive polycystic kidney disease encodes a large, receptor-like protein / C. J. Ward, M. C. Hogan, S. Rossetti [et al.] // Nat. Genet. - 2002. - Vol. 30, № 3. - P. 259-269.

10. The severe perinatal form of autosomal recessive polycystic kidney disease maps to chromosome 6p21.1-p12: Implications for genetic counselling / L. M. Guay-Woodford, G. Muecher, S. D. Hopkins [et al.] // Am. J. Med. Genet. — 1995. — Vol. 56, № 5. - P. 1101-1107.

\section{Ультразвукові прояви аутосомно-рецесивної полікістозної хвороби нирок у дітей}

\section{Б.А. Тарасюк 1 , I.В. Андрущенко 1, I.C. Лук'янова2}

1ДУ «Інститут ядерної медицини та променевої діагностики НАМН України», м. Київ, Україна

2ДУ «Інститут педіатрії, акушерства і гінекології НАМН України», м. Київ, Україна

Мета - оцінити результати комплексного ехографічного дослідження нирок і печінки в дітей з аутосомно-рецесивною полікістозною хворобою нирок.

Пацієнти та методи. Обстежено 9 дітей 3 даною патологією у віці від 3 до 16 років. Середній вік становив 6,2士2,3 року. Хлопчиків було 7, дівчаток 2. Сонографрічне дослідження проведено відповідно до стандартних протоколів на апаратах Acuson X300 (Siemens, Himeччина), MyLab Class C (ESAOTE, Італія). Використано мультичастотні конвексні 2-5 МГц. 3 метою детального вивчення паренхіми нирок і печінки високочастотне сканування датчиками 10 МГц.

Результати. При ехографрічному дослідженні у всіх випадках виявлено поєднане ураження нирок і печінки. При ехогепатографії зміни в печінці вкладалися в картину фіброзних змін різного ступеня вираженості. У всіх пацієнтів ураження нирок було двостороннім. Розміри нирок більші за вікові показники від 50 до 75\%. Контури нирок були рівними, чіткими. Диференціація паренхіматозного шару і чашково-мискової системи практично не визначалася.

Висновки. У всіх спостереженнях при комплексному ехографрічному дослідженні виявлялися структурні зміни в нирках і печінці, а також зміни показників регіонарного ниркового та печінкового кровотоку.

Ключові слова: аутосомно-рецесивна полікістозна хвороба нирок, вроджений фріброз печінки, діти, ехографрічне дослідження. 
PERINATOLOGIYA I PEDIATRIYA.2015.2(62):77-80;doi10.15574/PP.2015.62.77

The ultrasound signs of autosomic recessive policystic kidney disease in children

B.A. Tarasyuk1, I.V. Andruschenko1, I.S. Lukyanova2

$1 \mathrm{GU}$ «Institute for nuclear medicine and radiation diagnosis of NAMS of Ukraine», Kyiv, Ukraine

2SI «Institute of Pediatrics, Gynecology and Obstetrics NAMS of Ukraine», Kyiv, Ukraine

Objective — to evaluate the results of a comprehensive study echographic kidney and liver in children with autosomal recessive polycystic kidney disease.

Patients and methods. A total of 9 children with this pathology in age from 3 to 16 years. The median age was $6,2 \pm 2,3$ years. The boy was 7 , girls -2 .

Sonographic study was conducted according to standard protocols for devices Acuson X300 (Siemens, Germany), MyLab Class C (ESA0TE, Italy). Convex used multifrequency 2-5 MHz. For the purpose of detailed study of the renal parenchyma and liver used high-frequency sensors scan $10 \mathrm{MHz}$.

Results. When sonographic study of all cases revealed a combined kidney and liver. If changes in liver ehogepatografii fit into the picture of fibrotic changes of varying severity. All patients had bilateral renal, kidney size indicators were greater age from 50 to $75 \%$. The contours of the kidney were equal, precise. Differentiation parenchymal layer and pyelocaliceal system practically determined.

Conclusions. In all cases with complex sonographic study found structural changes in the kidney and liver, as well as changes in the indices of regional renal and hepatic blood flow.

Key words: autosomic recessive policystic kidney disease, liver fibrosis, children, echography.

Сведения об авторах:

Тарасюк Борис Андреевич - д.мед.н.,ст.н.сотр., зам директора по научной работе ГУ «Институт ядерной медицины и лучевой диагностики НАМН Украины». Адрес: г. Киев, ул. П. Майбороды,32; тел. (044) 489-00-94.

Андрущенко Ирина Викторовна - к.мед.н., ст.н.сотр, ученый секретарь «Институт ядерной медицины и лучевой диагностики НАМН Украины». Адрес: г. Киев, ул. П. Майбороды,32; тел. (044) 489-00-94.

Лукьянова Ирина Сергеевна - д.мед.н., профессор, зав.отделения ультразвуковой диагностики и пренатальной кардиологии ГУ «ИПАГ НАМН Украины». Адрес: г. Киев, ул. Майбороды, 8, тел. (044) 483-14-46.

Статья поступила в редакцию 5.05.2015 г.

\section{НОВОСТИ}

«Научный прорыв: в Украине создан единственный в мире препарат для лечения причин возникновения опасного вида рака»

24 июня 2015 г. состоится пресс-конференция на тему: «Научный прорыв: в Украине создан единственный в мире препарат для лечения причин возникновения опасного вида рака». Украинские ученые получили убедительные результаты 32-х доклинических и 20-ти клинических исследований, которые оказались сенсационными: испытуемый препарат отечественного производства показал высокие результаты эффективности по влиянию на вирус папилломы человека (ВПЧ), в том числе на его онкогенные типы. Фармацевтическими лабораториям ни в одной стране мира до сих пор не получено действующего вещества, способного противодействовать ВПЧ. То есть Украина первой создала уникальный препарат, который имеет доказанное прямое противовирусное действие на ВПЧ и дает возможность вылечить некоторые болезни, имеющие онкологическую перспективу, в частности, дисплазию шейки матки у женщин, которая почти гарантированно приводит к раку шейки матки.

Участники: Вячеслав Каминский, директор Киевского Центра репродуктивной и перинатальной медицины, Алла Корнадская, зав.отделением «Института педиатрии, акушерства и гинекологии НАМН Украины» Светлана Рыбалко, зав.лаборатории экспериментальной химиотерапии вирусных инфекций Института эпидемиологии и инфекционных заболеваний им. Л. Громашевского, Владислав Онищенко, председатель ОО «Союз потребителей медицинских услуг, лекарственных средств и изделий медицинского назначения», Анатолий Новик, председатель наблюдательного совета ООО «НПК «Экофарм», Александр Гриневич, зам. генерального директора ООО «НПК «Экофарм».

Адрес проведения: ул. Крещатик, 4, конференц-зал. Нужна аккредитация. Телефоны: 067-770-07-57, 050800-59-03. 


\title{
В.А. Дынник
}

\section{Характеристика клинического течения аномальных маточных кровотечений пубертатного периода в зависимости от дебюта заболевания}

\author{
ГУ «Институт охраны здоровья детей и подростков НАМН Украины», г. Харьков, Украина
}

PERINATOLOGIYA I PEDIATRIYA.2015.2(62):81-85;doi10.15574/PP.2015.62.81

\begin{abstract}
Цель - выяснить особенности анамнеза, физического и полового развития, сопутствующей соматической патологии у девочек-подростков с аномальными маточными кровотечениями в зависимости от дебюта заболевания.

Материалы и методы. Под наблюдением находилось 145 девочек-подростков с аномальными маточными кровотечениями в возрасте 11-18 лет. У всех обследуемых изучались акушерский анамнез, анамнез течения периода детства, перенесенные детские инфекции, сопутствующая соматическая патология, становления менструальной функции, физическое и половое развитие.

Результаты. Пациентки при дебюте нарушений менструальной функции с маточными кровотечениями чаще имели отягощенный перинатальный анамнез. Причем при манифестации кровотечения в первый год менструальной функции чаще регистрировались гестозы беременности и патологическое течение родов, а при формировании кровотечения на втором году менструальной функции и позже - угроза прерывания в разные сроки гестации и дистресс плода. У больных с дебютом кровотечения в первый год менструальной функции достоверно чаще отмечалось опережение полового развития, а на втором и позже годах - раннее менархе. У пациенток при фрормировании маточного кровотечения на втором году менструальной функции и позже, но манифестации нарушений с олигоменореи, значительно реже отмечались оптимальные параметры физического развития чаще, чем у других регистрировалась ретардация полового развития, различные кожные проявления гиперандрогении. Достоверно чаще они воспитывались в неполных или деструктивных семьях, имели три или более сопутствующих соматических заболевания. Выводы. Установлено, что клиническое течение аномальных маточных кровотечений пубертатного периода имеет свою специфику, зависящую от сроков появления первого кровотечения и предшествующих нарушений менструальной функции.
\end{abstract}

Ключевые слова: аномальные маточные кровотечения, пубертатный период, клиническое течение, манифестация заболевания.

\section{Введение}

Dепродуктивная система женского организма реализует свой потенциал на протяжении фертильного возраста, однако ее становление в значительной мере зависит от течения наиболее критических периодов жизни женщины, в первую очередь это касается пубертата. Период полового созревания является очень важным в развитии женского организма. Формирование у девочки репродуктивного потенциала, а в будущем и репродуктивного здоровья зависит от того, как он протекает, насколько здоровой в него вступает девочка $[2,4,11]$.

В последнее десятилетие на фоне увеличивающейся гинекологической патологии у девочек резко возросли нарушения менструальной функции $[1,8,10]$. Это является результатом неустойчивости системы регуляции менструальной функции у девочек и высокой ее чувствительности к влиянию неблагоприятных факторов окружающей среды, к заболеваниям, интоксикациям, а также учебным, эмоциональным и физическим перегрузкам [5].

Среди нарушений менструальной функции в периоде пубертата одними из наиболее тяжелых по своему течению являются аномальные маточные кровотечения. По данным Уваровой Е.В. и Веселовой Н.М. [9], женщины, перенесшие маточное кровотечение в пубертатном периоде, страдают первичным бесплодием (82\%), невынашиванием беременности (8\%) и лишь каждая десятая имеет ребенка. Большое количество аспектов этой проблемы в той или иной степени изучены, однако очень много вопросов требуют дальнейшего своего изучения и разрешения.

Цель работы - выяснить особенности анамнеза, физического и полового развития, сопутствующей соматической патологии у девочек-подростков с аномальными маточными кровотечениями (АМК) в зависимости от дебюта заболевания.

\section{Материалы и методы исследования}

Под наблюдением было 145 девочек-подростков с АМК в возрасте 11-18 лет, находившихся на лечении в отделении детской гинекологии ДУ «Институт охраны здоровья детей и подростков НАМН». Они были разделены на следующие группы: I группу составили пациентки, у которых нарушение менструальной функции возникло в 1 год ее становления, причем дебютировало оно с АМК (с менархе или в первые 12 мес. - 75 подростков). Во II группу вошли девочки, у которых маточные кровотечения сформировались на второй год и позже от начала менструальной функции (50 человек). У 24 пациенток нарушения на втором году менструальной функции и позже манифестировали с AMК (II-а группа) и у 26 пациенток маточному кровотечению на втором году менструальной функции и позже предшествовали другие расстройства, в основном олигоменорея (II-б группа).

У всех обследуемых изучался акушерский анамнез, анамнез течения периода детства, перенесенные детские инфекции, сопутствующая соматическая патология, становления менструальной функции. Проводилось антропометрическое исследование, включавшее измерение роста, массы тела, окружности талии (ОТ) и окружности бедер (ОБ). Для оценки массы тела использовался индекс массы тела (ИМТ), рассчитываемый как отношение массы тела (в килограммах) к росту (в метрах), возведенному в квадрат, оценивалось половое развитие по степени выраженности вторичных половых признаков. При оценке степени полового созревания использовалась модифицированная методика Тумилович Л.Г. и соавт., в основу которой положена цифровая (балльная) оценка степени развития каждого полового признака и их биологической значимости [6].

Статистический анализ данных проводился с использованием пакета прикладных программ «Statgraphics Plus for Windows 3.0» (Manugistic Inc., USA). Значимость различий между группами оценивалась с помощью критериев углового преобразования Фишера, WilcoxonMann-Whitney, $\chi^{2}$. Разница в показателях считалась достоверной при $\rho<0,05$.

\section{Результаты исследования и их обсуждение}

Изучение акушерского анамнеза матерей больных выявило, что патологическое течение беременности и 


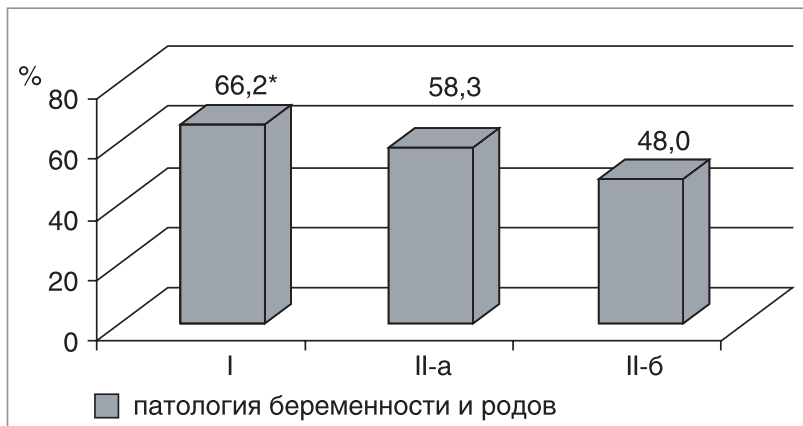

Рис. 1. Осложненное течение беременности и родов у матерей пациенток с аномальными маточными кровотечениями

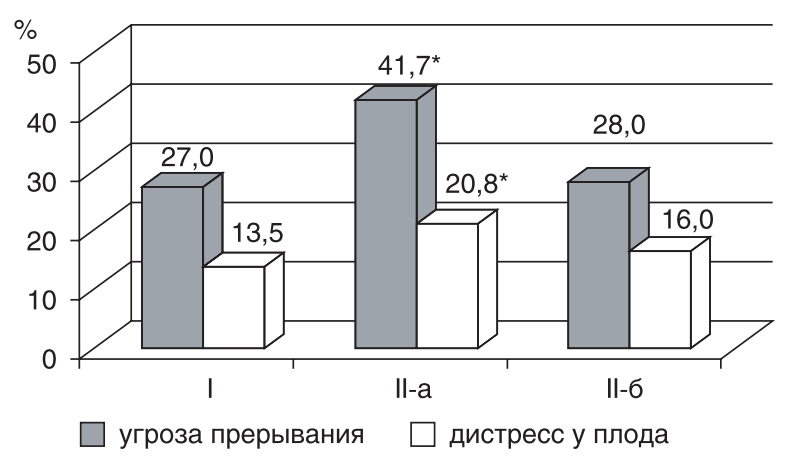

Pис. 2. Удельный вес матерей с патологией беременности и наличие дистресса у плода

родов отмечалось более чем у половины. Причем наиболее часто отклонения в течение беременности и родов имели место у матерей пациенток I группы - 66,2\% $\left(\mathrm{p}_{1,2}<0,0001 ;\right.$ рис. 1$)$.

Следует отметить, что у матерей подростков II-а группы наиболее часто беременность осложнялась угрозой прерывания и дети рождались в состоянии дистресса (рис. 2).

Почти каждая третья девочка с АМК воспитывалась в неполной и/или деструктивной семье, чаще всего это отмечалось среди подростков ІІ-б группы $\left(\mathrm{p}_{1,2}<0,005\right.$; рис. 3$)$.

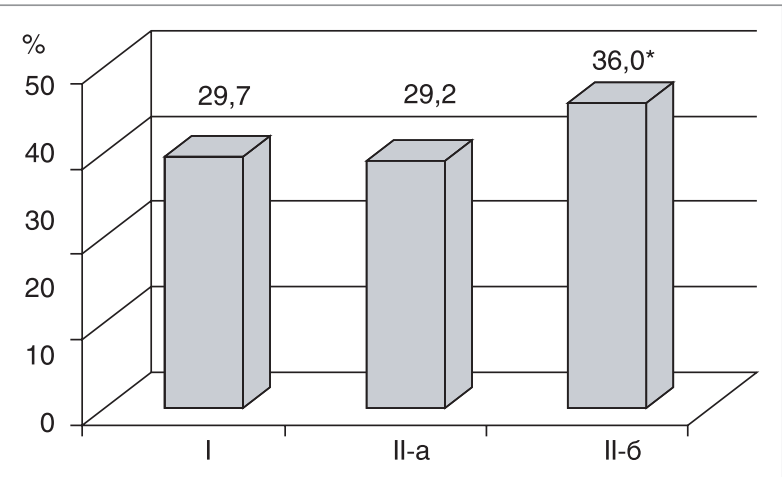

Pис. 3. Количество неполных и/или деструктивных семей

Возраст матерей и отцов на момент рождения наших пациенток у абсолютного большинства составлял 20-30 лет. Однако часть наших больных рожали матери, чей возраст на момент рождения был младше 19 лет и старше 30-35 лет (рис. 4).

Девочек из II-б группы реже рожали матери в оптимальном фертильном возрасте $\left(\mathrm{p}_{1}<0,001 ; \mathrm{p}_{2}<0,005\right)$, $20-30 \%$ родителей детей этой группы на момент рождения ребенка имели возраст или менее 19 лет, или старше 30-35 лет. Подростков из II-а группы реже рожали юные матери $\left(\mathrm{p}_{1,2}<0,001\right)$, однако почти каждая третья-четвертая девочка рождалась в семье, где возраст родителей составлял старше 30 или 35 лет. Пациентки I группы достоверно реже рождались у родителей, чей возраст на момент родов превышал 30-35 лет $\left(\mathrm{p}_{1,2}<0,001\right)$.

Приведенные данные о высокой частоте патологии беременности и родов, рождения юными и родителями после 30-35 лет позволяют предположить, что уже в перинатальном периоде наши пациентки подверглись неблагоприятному влиянию, которое сыграло свою негативную роль и привело к возникновению нарушений менструальной функции в периоде пубертата.

Анализ возраста пациенток выявил, что средние его показатели были наименьшими в I группе $(13,28 \pm 0,17$ года против $14,88 \pm 0,28$ года во II-а группе и $15,25 \pm 0,30$ года во II-б группе; $\left.\mathrm{p}_{1,2}<0,0001\right)$. Достоверных различий

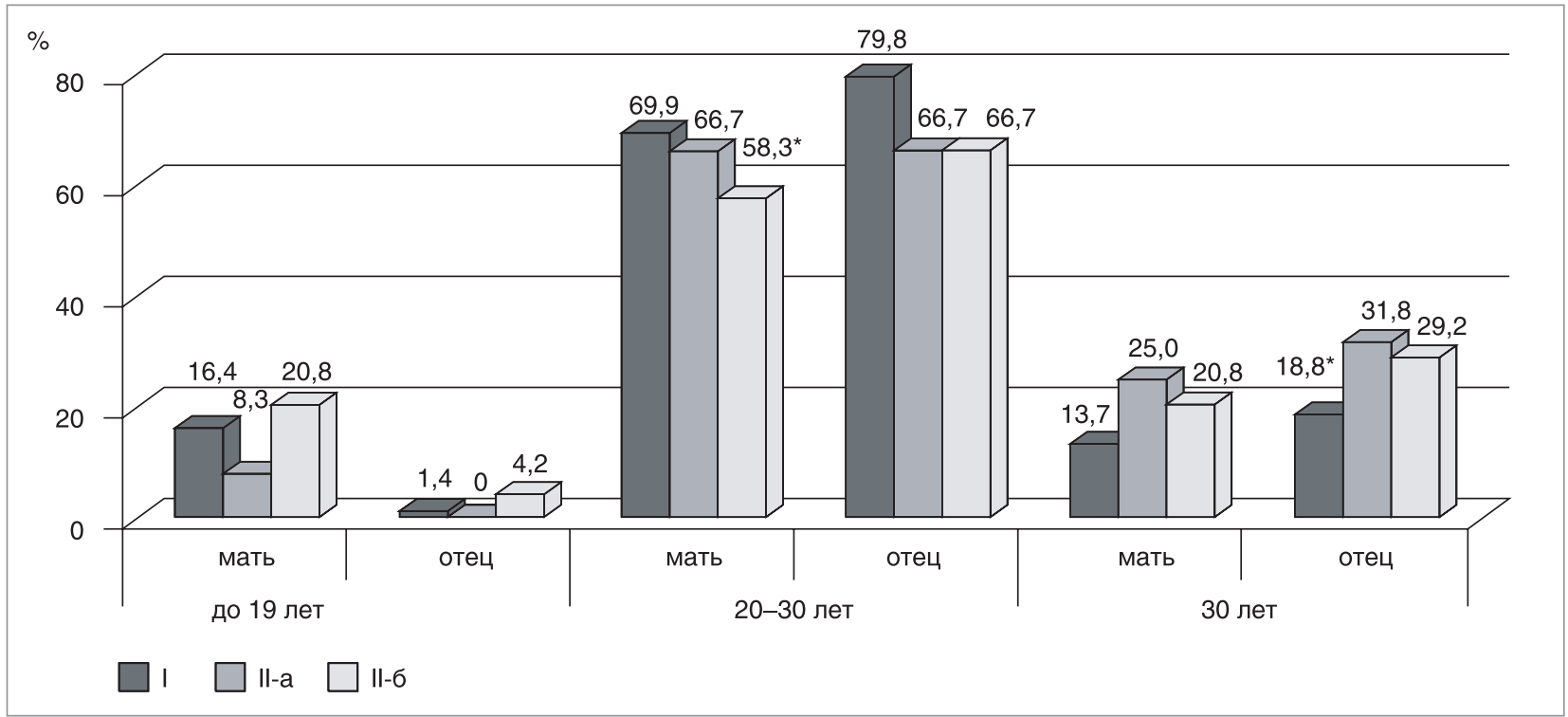

Pис. 4. Возраст родителей на момент рождения наших пациенток 


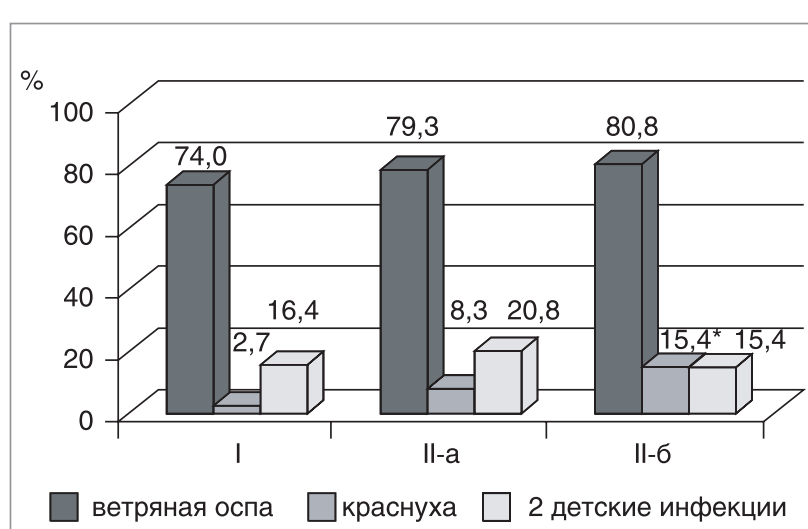

Pис. 5. Удельный вес больных, перенесших детские инфекции

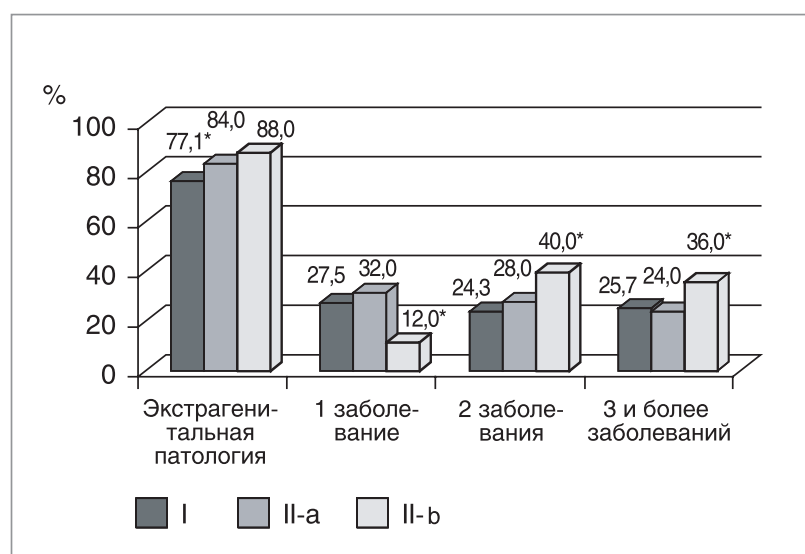

Pис. 6. Наличие сопутствующей соматической патологии

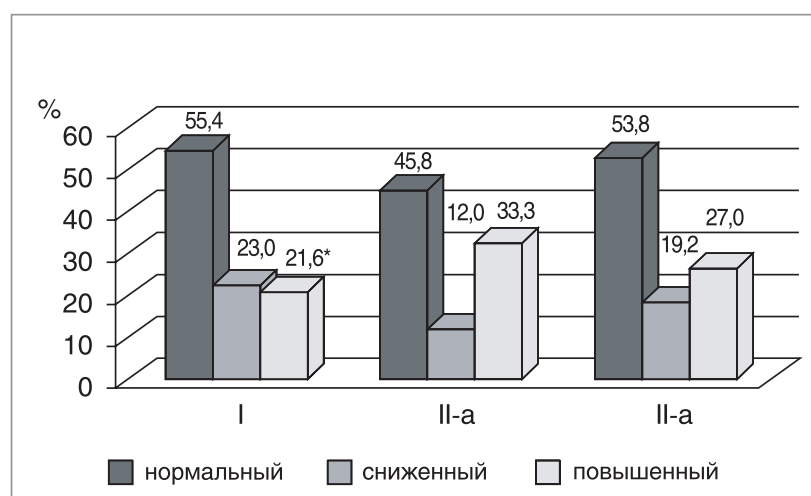

Pис. 7. Удельный вес пациенток с различным индексом массы тела

в возрастном диапазоне больных II-а и II-б групп не выявлено.

Важную роль в формировании АМК в период пубертата играют хронические и острые инфекционные заболевания. Их токсическое влияние может приводить к нарушениям гипоталамо-гипофизарно-гонадных взаимоотношений. Изучение анамнестических данных наших пациенток показало, что только небольшая часть подростков не перенесла детские инфекции, причем чаще это были девочки из I группы ( $\left.\mathrm{p}_{1}<0,001 ; \mathrm{p}_{2}<0,005\right)$. Около $80 \%$ обследованных детей вне зависимости от группы переболели одной или более детскими инфекциями.
Самыми распространенными инфекциями были ветряная оспа и краснуха (рис. 5). Причем если ветряная оспа регистрировалась с одинаковой частотой, то краснухой переболели чаще всего подростки II-б группы ( $p_{1}<0,001$; $\left.\mathrm{p}_{2}<0,01\right)$. Инфекционный индекс был невысоким. Наличие трех детских инфекций в анамнезе регистрировалось в единичных случаях, а двух - у 15-20\% больных.

Более чем у трети пациенток наблюдались очаги хронической инфекции и интоксикации различной локализации (хронический тонзиллит, фарингит, ринит, кариес и т.д.). Причем у подростков I группы они отмечались значительно реже, чем в других группах $\left(27,1 \%\right.$; $\mathrm{p}_{1}<0,05$; $\left.\mathrm{p}_{2}<0,01\right)$. У девочек II-б группы очаги хронической инфекции регистрировались достоверно чаще - почти у каждой второй (48\%; $\left.\mathrm{p}_{1,2}<0,0001\right)$. Массивная вирусная интервенция еще в детстве может приводить к нарушениям как со стороны центральных регулирующих механизмов, так непосредственно влиять на гонады [3, 7].

Изучение экстрагенитальной патологии выявило, что у абсолютного большинства подростков соматический статус был осложнен сопутствующими заболеваниями (рис. 6). Однако, несмотря на значительную частоту сопутствующей соматической патологии, хронические заболевания не носили тяжелый характер. Реже всего они отмечались у больных I группы $\left(77,1 \% ; \mathrm{p}_{1}<0,05 ; \mathrm{p}_{2}<0,01\right)$. Следует отметить, что у пациенток II-б группы значительно чаще регистрировались три и более сопутствующих экстрагенитальных заболеваний (36\% против $25,6 \%$ в I группы и $24 \%$ - во II-а группе; $\left.\mathrm{p}_{1}<0,01 ; \mathrm{p}_{2}<0,001\right)$ и реже - одно $\left(12 \% ; \mathrm{p}_{1,2}<0,0001\right)$. В структуре соматической патологии ведущее место в I и II-а группах занимали нарушения эндокринной системы (48,6\% и $52,0 \%$ соответственно). На втором месте были заболевания нервной системы (31,4\% и 40,0\% соответственно). У пациенток II-б группы, наоборот, первое место занимали заболевания нервной системы (68\%), а второе - эндокринной (44\%). Причем следует отметить, что среди эндокринной патологии 70-80\% приходились на ДНЗ I-II степени. В неврологическом статусе 35-60\% приходилось на астенические, невротические реакции, церебростении, $25-40 \%$ - на ликворно-гипертензионный синдром, 20-30\% - на вегетососудистую дистонию.

В рамках интегральной оценки состояния здоровья изучалось физическое развитие. Особенности физического развития выражались в том, что у подростков I группы высокорослость (>2 SDS) выявлялась чаще, чем в двух других группах $\left(\mathrm{p}_{1,2}<0,05\right)$. ИМТ в среднем не имел различий во всех трех группах. Однако проведение индивидуального анализа выявило, что только у половины больных ИМТ соответствовал нормативным показателям. Дефицит массы тела встречался с одинаковой частотой, избыточная масса тела и/или ожирение у подростков I группы регистрировалось значительно реже, чем в двух других группах (21,6\% против $33,3 \%$ во II-а группе и $27,0 \%$ во II-б группе; p1,2<0,01; рис. 7). В связи с чем средние параметры массы тела у этого контингента больных в среднем уступали пациенткам из двух других групп $\left(\mathrm{p}_{1}<0,004 ; \mathrm{p}_{2}<0,02\right)$. Показатели OT, ОБ и их соотношения не имели существенных различий в обследуемых группах и в среднем составили: ОТ $69,68 \pm 0,93$ см; ОБ $-91,65 \pm 1,0$ см; ОТ /ОБ $-0,76 \pm 0,006$.

Средний возраст менархе был наименьшим у пациенток II-a группы - 11,91 $\pm 0,24$ года (I группы $-12,54 \pm 0,14$ года, II-б группы $-12,50 \pm 0,25$ года; $\left.\mathrm{p}_{1}<0,01 ; \mathrm{p}_{2}<0,04\right)$. У них же значительно чаще регистрировалось раннее менархе (до 11 лет) 29,2\% против 9,5\% в I группе и 19,2\% во II-б группе $\left(\mathrm{p}_{1,2}<0,001\right)$. 
У младших девочек I группы (11-14 лет) достоверно чаще регистрировалось опережение полового развития (39,5\% против 33,3\% во II-а группе и 33,3\% во II-б группе; $\left.\mathrm{p}_{1,2}<0,001\right)$. Отставание полового созревание у старших подростков значительно чаще выявлялось у пациенток II-б группы $\left(8,7 \%\right.$ против $3,2 \%$ в I группе; $\left.\mathrm{p}_{1}<0,001\right)$. Среди больных II-а группы отставание полового развития не отмечалось.

Сопоставление характера маточного кровотечения по группам выявило, что формирование ремитирующего типа кровотечений наиболее характерно для подростков, у которых аномальное маточное кровотечение возникает c менархе или в первый год становления функции (І группы).

При дебюте маточного кровотечения на первом и последующих годах менструальной функции различные проявления андрогенной дермопатии (АДП) выявлялись с одинаковой частотой $(18,9 \%$ - I группы, $20,8 \%$ II-a группы). При возникновении маточного кровотечения на втором году формирования менструальной функции и позже, но при манифестации нарушений с олигоменореи АДП встречалось достоверно чаще $(30,8 \%$; $1,2<0,001)$.

Подростки I и II-а группы чаще, чем пациентки II-б группы, обращались за медицинской помощью при длительности кровотечения до 2 недель (48,6\% и 41,7\% соответственно против $\left.34,6 \% ; \mathrm{p}_{1,2}<0,01\right)$. То есть даже при наличии кровотечения - ярко выраженной патологии, больные не всегда спешат к врачу.

При ультразвуковом исследовании (УЗИ) органов малого таза только у трети пациенток всех трех групп выявлялись нормативные размеры матки (I группы 26,7\%; II-а группы - 37,5\% и II-б группы - 30,8\%). У большинства размеры матки превышали возрастную норму (I группы - 70,7\%; II-а группы - 62,5\%, II-6 группы - 69,2\%). Наличие внутриматочного М-эхо более 10 мм отмечалось у 66,7\% девочек I группы, 62,5\% пациенток II-а группы и значительно реже у 53,8\% подростков II-б группы $(p 771,2<0,05)$. Увеличенные фолликулы и/или кисты яичников также достоверно реже регистрировались у пациенток II-б группь (15,4\% против $30,7 \%$ в I группе и $45,8 \%$ во II-а группе; $\left.\mathrm{p}_{1,2}<0,001\right)$
Таким образом, установлены особенности клинического течения, анамнестических данных у пациенток с АМК ПП, которые зависят от сроков появления первого кровотечения и манифестации любых нарушений менструальной функции.

\section{Выводы}

1. При дебюте маточного кровотечения с менархе или в первый год становления менструальной функции для пациенток характерны более низкие параметры веса, значительно реже регистрируется избыточная масса тела и/или ожирение, достоверно чаще у больных 11-13 лет наблюдается опережение полового развития. Эти девочки значительно реже переносят различные детские инфекции, имели сопутствующую соматическую патологию и очаги хронической инфекции. Кровотечения у них чаще носят ремиттирующий характер. У матерей этих пациенток достоверно чаще отмечаются патологические отклонения в течение беременности и родов.

2. У больных с дебютом маточного кровотечения на втором году менструальной функции и позже возраст менархе наименьший, у них достоверно чаще регистрируется ранее менархе. У матерей этой группы больных чаще, чем у других, беременность осложняется угрозой прерывания в разные сроки гестации, а дети рождаются с дистресс-синдромом.

3. У пациенток при дебюте маточного кровотечения на втором году менструальной функции и позже, но при манифестации нарушений с олигоменореи, значительно реже отмечаются оптимальные параметры физического развития, чаще, чем у других девочек, регистрируется ретардация полового развития, различные кожные проявления гиперандрогении. Достоверно чаще такие девочки воспитываются в неполных или деструктивных семьях, имеют три или более сопутствующих соматических заболевания, причем ведущей является патология со стороны нервных болезней, в отличие от двух других групп, где ведущей соматической является эндокринная патология. Значительно реже они рождены матерями в оптимальном фертильном возрасте. При УЗИ органов малого таза у этих пациенток достоверно реже выявляется гиперплазия эндометрия и кисты яичников.

\section{ЛИТЕРАТУРА}

1. Аналіз та тенденції захворюваності дитячого населення України Р.О. Моісеєнко, Я.І. Соколовська, Т.К. Кульчицька, Т.М. Бухановська // Современная педиатрия. - 2010. - № 3 (31). - С. 13-17.

2. Быстрицкая Т.С. Прогнозирование плацентарной недостаточности у беременных с нарушениями становления менструальной функции в пубертатном периоде / Т.С. Быстрицкая, Н.Н. Штель, Д.С. Лысяк // Бюллетень физиологии и патологии дыхания. - 2011. Вып. 42. - С. 55-59.

3. Гуркин Ю.А. Концепция «перинатального следа» в детской гинекологии / Ю.А. Гуркин // Современные профилактические, диагностические и терапевтические технологии в клинике детской гинекологии: сб. тр. IV Всерос. конф. по детской и подростковой гинекологии. - СПб., 2000. - С. 55.

4. Думанская Ю.А. Влияние нарушений менструальной функции в пубертатном периоде на состояние костной ткани: обзор литературы / Ю.А. Думанская, Э.А. Щербавская // Проблемы репродукции. -2008 . - № 2. - С. 17-21.

5. Калашникова И.В. Нарушения менструальной функции в популяции девушек-подростков белгородской области / И.В. Калашникова, В.С. Орлова, Г.М. Курганская // Научные ведомости Белгородского государственного университета. - 2010. Вып. 9, № 4 (75). - С. 18-26.
6. Левенець С.О. Клініко-гормональна характеристика затримки розвитку жіночої статевої системи центрального ґенезу / С.О. Левенець, О.І. Плехова // Акушерство и гинекология. 1986. - № 7. - С. 50-53.

7. Мамчиц А.П. Особенности краснухи в современных условиях А.П. Мамчиц // Актуальные проблемы современной медицины: матер. междунар. науч. конф. студентов и молодых ученых, посвященной 85-летию Белорусского гос. мед. ун-та. - Минск, 2006. - С. 302-303.

8. Митин В. Состояние здоровья девочек и девушек-подростков в современных условиях / В. Митин // Рос. вестник акушера-гинеколога. -2005 . - № 3. - С. 19-23.

9. Принципы междисциплинарного решения проблемы маточных кровотечений пубертатного периода / Е.В. Уварова, Н.М. Веселова, И.А. Сальникова, И.М. Лободина // Вопросы соврем. педиатрии. 2007. - Т. 6, № 1. - С. 76-79.

10. Султанаева 3.М. Заболеваемость в детском и подростковом возрасте как фактор формирования репродуктивного здоровья / 3.М. Султанаева, И.Х. Шарафутдинова // Здравоохранение Рос. Федерации. - 2010. - № 2. - С. 22-25.

11. Хамошина М.Б. Ювенильная гинекология: проблемы и перспективы XXI века / М.Б. Хамошина, М.Г. Лебедева, М.И. Вахабова // Вестник репродуктивного здоровья. - 2011. - Вып. 2. - С. 30-33. 


\author{
Характеристика клінічного перебігу аномальних маткових кровотеч \\ пубертатного періоду залежно від дебюту захворювання \\ в.0. Диннік
}

ДУ «Інститут охорони здоров'я дітей та підлітків НАМН України», м. Харків, Україна

Мета - з'ясувати особливості анамнезу, фізичного і статевого розвитку, супутньої соматичної патології в дівчат-підлітків 3 аномальними матковими кровотечами залежно від дебюту захворювання.

Пацієнти та методи. Під спостереженням знаходилося 145 дівчат з аномальними матковими кровотечами віком 11-18 років. В усіх обстежених вивчався перинатальний анамнез, період дитинства, перенесені дитячі інфекції, супутня соматична патологія, становлення менструальної функції, фрізичний та статевий розвиток.

Результати. При дебюті захворювання з аномальних маткових кровотеч у пацієнток значно частіше відмічався обтяжений перинатальний анамнез. Причому при маніфестації маткової кровотечі в перший рік існування менструальної функції частіше реєструвалися гестози вагітних і патологічний перебіг пологів, а при формуванні кровотечі на другому році менструальної функції і пізніше - загроза переривання в різні строки гестації і дистрес плода. У хворих з дебютом маткової кровотечі у перший рік менструальної фрункції вірогідно частіше реєструвалося випередження статевого розвитку, а на другому році менструальної функції і пізніше — раннє менархе. У пацієнток при формуванні маткової кровотечі на другому році менструальної функції і пізніше, але маніфестації порушень з олігоменореї, значно зменшувався відсоток дівчат з оптимальними параметрами фрізичного розвитку, частіше виявлялася ретардація статевого дозрівання, різні шкірні прояви гіперандрогенії. Достовірно частіше вони виховувалися в неповних i/або деструктивних сім'ях, мали три і більше супутніх соматичних захворювання.

Висновки. Установлено, що клінічний перебіг аномальних маткових кровотеч пубертатного періоду має свою специфіку, яка залежить від строків появи першої маткової кровотечі й попередніх порушень менструальної функції.

Ключові слова: аномальні маткові кровотечі, пубертатний період, клінічний перебіг, маніфестація захворювання.

PERINATOLOGIYA I PEDIATRIYA.2015.2(62):81-85;doi10.15574/PP.2015.62.81

Characteristics of clinical flow of anomalous uterine bleeding pubertal period depending on the onset of the disease

V.A. Dynnik

SI «Institute for Children and Adolescents Health Care of the NAMS of Ukraine», Kharkiv, Ukraine

Purpose - to find out the peculiarity of history, physical, sexual development, concomitant somatic pathology in adolescents with abnormal uterine bleeding (BUN), depending on the onset of the disease.

Patients and methods. We observed 145 adolescent girls with AMC aged 11-18. All subjects were studied obstetrical history, current history of childhood endured childhood infections, concomitant somatic pathology, formation of menstrual function, physical, sexual development.

Results. Patients with onset of menstrual dysfunction with uterine bleeding more likely to have weighed perinatal history. And at the manifestation of bleeding in the first year of menstrual function often recorded gestosis pregnancy and pathological course of delivery, and the formation of bleeding in the second year of menstrual function, and later - the threat of interruption at different stages of gestation and fetal distress. Patients with bleeding debut in the first year of menstrual function significantly more often mentioned ahead of sexual development, and the second and later years - early menarche. Patients in the formation of uterine bleeding in the second year of menstrual function and later, but the manifestation of disorders with oligomenorhea significantly less likely to have the optimal parameters of physical development, are more likely than other registered retardation of sexual development, various skin manifestations of hyperandrogenism. Significantly more often they were brought up in single-parent families or destructive, had three or more comorbid medical illness.

Conclusion. It was found that the clinical course of abnormal uterine bleeding puberty has its own specifics, depending on the timing of appearance of the first bleeding and previous menstrual dysfunction.

Key words: abnormal uterine bleeding, puberty, clinical course, a manifestation of the disease.

Сведения об авторах:

Дынник Виктория Александровна - д.мед.н., ученый секретарь ГУ «Институт охраны здоровья детей и подростков НАМН Украины». Адрес: г. Харьков, пр. 50-летия ВлКСМ, 52-А; тел. (0572) 62-71-70; e-mail: viktorija-dynnik@yandex.ua.

Статья поступила в редакцию 30.04.2015 г. 


\title{
М.Л. Аряєв, Л.В. Васильченко, Н.Л. Мерікова, І.М. Шевченко Клініко-біохімічне обгрунтування застосування ентерособції в новонароджених з гемолітичною хворобою
}

\author{
Одеський національний медичний університет, м. Одеса, Україна
}

\author{
PERINATOLOGIYA I PEDIATRIYA.2015.2(62):86-89;doi10.15574/PP.2015.62.86
}

\begin{abstract}
Мета - поліпшити результати терапії гемолітичної хвороби в новонароджених шляхом розробки показань та методики ентеросорбції ентеросгелем з урахуванням клініко-лабораторних особливостей захворювання.

Пацієнти та методи. Обстежено 92 хворих на різні варіанти гемолітичної хвороби (основна група), які в комплексній терапії отримували ентеросгель. У 37 дітей захворювання обумовлене несумісністю крові матері та дитини за резус-фактором, у 55 - консрліктом за АВ0-системою. Контрольна група складалася з 20 дітей з різноманітними ступенями тяжкості гемолітичної хвороби, в яких ентеросорбція в комплексному лікуванні не використовувалася (легкий перебіг - 10 новонароджених, середньої тяжкості - 6, тяжкий - 4). Есфективність застосування ентеросгелю оцінювалась за клінічними (тривалість жовтяничного періоду, час перебування у стаціонарі, динаміка неврологічних симптомів) і лабораторними показниками (гемоглобін), біохімічним дослідженням (білірубін, гепатоспецисічні ферменти - аланінамінотранссрераза, аспартатамінотрансфераза, лактатдегідрогеназа), показниками синдрому ендогенної інтоксикації (середньомолекулярні пептиди). Обробка отриманих даних проводилась за допомогою методів математичної статистики з обчисленням середніх величин і середньоквадратичних відхилень, а також коефіцієнта Стьюдента.

Результати. Встановлено, що введення ентеросгелю до комплексної терапії різних форм гемолітичної хвороби підвищує ефективність лікування ізоімунного конфрлікту, що характеризується скороченням тривалості жовтяниці, поліпшенням функції печінки, зменшенням активності лактатдегідрогенази та гепатоспецифічних ферментів, ознак білірубінової та ендогенної інтоксикації, більш швидкою елімінацією білірубіну та середньомолекулярних пептидів. Позитивний ефект застосування ентеросгелю в комплексній терапії підтверджений зменшенням кількості замінного переливання крові та терміну перебування в стаціонарі.

Висновки. Ентеросорбція з використанням ентеросгелю не викликає побічних реакцій та ускладнень і, за даними катамнезу, не чинить негативного впливу на фізичний та психомоторний розвиток дітей. Включення методу ентеросорбції в комплекс постнатальної терапії гемолітичної хвороби плода і новонародженого дає змогу знизити рівень перинатальної смертності та тяжких уражень центральної нервової системи. Ключові слова: новонароджені діти, гемолітична хвороба новонароджених, ентеросорбція.
\end{abstract}

\section{Вступ}

Гемолітична хвороба новонароджених (ГХН) зали-

1 шається актуальною проблемою сучасної перинатології. Важливість і значущість цієї патології обумовлена тим, що вона досить часто спричиняє антенатальну загибель плода і смертність новонароджених у ранньому неонатальному періоді, а також органічні ураження центральної нервової системи, що призводить у частини дітей до глибокої інвалідизації $[1,9]$.

Дослідники попередніх років вказують на важливу роль порушення білірубінового обміну в патогенезі ГХН i накопичення токсичних речовин у крові, які негативно впливають на перебіг хвороби та подальший розвиток дитини. Серед сучасних методів лікування ГХН основне місце належить операціям замінного переливання крові (ОЗПК) та фототерапії. Однак, враховуючи значне поширення інфекцій, які передаються через кров та їі препарати, ризик інфікування дітей при гемотрансфузіях зростає. Довготривале застосування фототерапії також негативно впливає на новонародженого і проявляється розвитком ретинопатій, синдрому «бронзової дитини», фотодерматитами $[1,2,3,5,6,7,8]$. Це слугує підставою для пошуку та розробки нових, більш безпечних способів лікування ізоімунного конфлікту. У медичній практиці серед сучасних способів лікування різноманітних нозоформ широко застосовуються малоінвазивні екстракорпоральні методи очищення організму, засновані на сорбції та виведенні токсичних речовин 3 організму через шлунково-кишковий тракт. Тому перспективним методом лікування ГХН, спрямованим на зниження вмісту продуктів білірубінового обміну та продуктів незавершеного метаболізму з крові, є метод ентеральної сорбції [4].

У процесі клінічних досліджень вітчизняних і зарубіжних вчених визначені механізми лікувальної дії кишкових сорбентів при різноманітних захворюваннях у дорослих та дітей старшого віку [4]. Застосування ентеросорбентів у ранньому неонатальному періоді вивчене недостатньо.

Mema роботи - поліпшити результати терапії ГХН шляхом розробки показань та методики ентеросорбції ентеросгелем з урахуванням клініко-лабораторних особливостей захворювання.

\section{Матеріали та методи дослідження}

У ході виконання роботи обстежено 92 хворих на різні варіанти ГХН (основна група), які в комплексній терапії отримували ентеросгель. У 37 дітей захворювання обумовлене несумісністю крові матері та дитини за резус-фактором, у 55 - конфліктом за АВО-системою. Усі діти розподілені на 3 групи залежно від ступеня тяжкості ізоімунного конфлікту. 1-а група складалася 318 новонароджених із легким перебігом хвороби, 2-а група - з 56 дітей 3 ознаками середньотяжкої ГХН, 3-я група - з 18 хворих із тяжким перебігом захворювання. Контрольна група складалася з 20 дітей з різноманітними ступенями тяжкості ГХН, у яких ентеросорбція в комплексному лікуванні не використовувалася (легкий перебіг -10 новонароджених, середньої тяжкості -6 , тяжкий -4$)$.

Комплекс клінічного обстеження включав акушерський анамнез матерів, дані об'єктивного обстеження дітей, лабораторні та біохімічні показники (непрямий білірубін, гемоглобін, еритроцити, аланінамінотрансфераза, аспартатамінотрансфераза, лактатдегідрогеназа) і спеціальні дослідження (середньомолекулярні пептиди).

Проведені дослідження показали суттєве значення материнської патології серед причин і чинників розвитку захворювання та ступеня тяжкості процесу. Більшість дітей народились від матерів із високим ступенем ризику перинатальної патології (63,3\%). Ступінь ризику визначався патологічним перебігом анте- та інтранатального 
Динаміка клінічних і лабораторних показників у дітей з легким перебігом гемолітичної хвороби на фоні застосування ентеросгелю

\begin{tabular}{|c|c|c|c|}
\hline Показник & 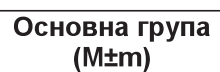 & 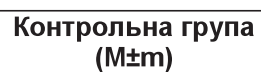 & $\mathbf{p}$ \\
\hline Тривалість жовтяничного періоду (діб) & $6,6 \pm 0,14$ & $7,7 \pm 0,17$ & $<0,01$ \\
\hline Тривалість перебування у стаціонарі (діб) & $6,8 \pm 0,16$ & $7,9 \pm 0,17$ & $<0,01$ \\
\hline Білірубін (мкмоль/л) & $98,6 \pm 4,3$ & $119,9 \pm 5,1$ & $<0,001$ \\
\hline Гемоглобін (г/л) & $168,9 \pm 1,8$ & $149,9 \pm 1,4$ & $<0,01$ \\
\hline Середньомолекулярні пептиди (у.о.) & $0,302 \pm 0,011$ & $0,425 \pm 0,017$ & $<0,01$ \\
\hline Аланінамінотрансфераза (UE/I) & $26,8 \pm 1,3$ & $29,8 \pm 1,9$ & $<0,01$ \\
\hline Аспартатамінотрансфераза (UE/l) & $47,1 \pm 4,1$ & $53,3 \pm 4,3$ & $<0,01$ \\
\hline Лактатдегідрогеназа (UE/I) & $459,3 \pm 18,5$ & $537,4 \pm 19,4$ & $<0,01$ \\
\hline
\end{tabular}

Динаміка клінічних і лабораторних показників у дітей

із середньотяжким перебігом гемолітичної хвороби на фоні застосування ентеросгелю

\begin{tabular}{|c|c|c|c|}
\hline Показник & 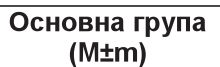 & 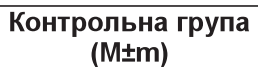 & $\mathbf{p}$ \\
\hline Тривалість жовтяничного періоду (діб) & $9,2 \pm 0,12$ & $10,4 \pm 0,17$ & $<0,01$ \\
\hline Терміни відновлення рефлексів (діб) & $8,1 \pm 0,11$ & $9,2 \pm 0,14$ & $<0,01$ \\
\hline Тривалість перебування в стаціонарі (діб) & $9,6 \pm 0,16$ & $10,2 \pm 0,14$ & $<0,01$ \\
\hline Білірубін (мкмоль/л) & $131,5 \pm 4,4$ & $155,2 \pm 3,8$ & $<0,001$ \\
\hline Гемоглобін (г/л) & $160,4 \pm 2,8$ & $147,7 \pm 2,4$ & $<0,01$ \\
\hline Середньомолекулярні пептиди (у.о.) & $0,407 \pm 0,012$ & $0,496 \pm 0,006$ & $<0,01$ \\
\hline Аланінамінотрансфераза (UE/I) & $27,0 \pm 1,9$ & $32,3 \pm 2,4$ & $<0,01$ \\
\hline Аспартатамінотрансфераза (UE/I) & $49,2 \pm 2,1$ & $60,6 \pm 3,8$ & $<0,01$ \\
\hline Лактатдегідрогеназа (UE/I) & $528,3 \pm 21,1$ & $611,1 \pm 20,3$ & $<0,01$ \\
\hline
\end{tabular}

Динаміка клінічних і лабораторних показників у дітей

Таблиия 3

із тяжким перебігом гемолітичної хвороби на фоні застосування ентеросгелю

\begin{tabular}{|c|c|c|c|}
\hline Показник & 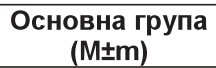 & 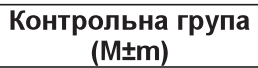 & $\mathbf{p}$ \\
\hline Тривалість жовтяничного періоду (діб) & $13,0 \pm 0,26$ & $14,2 \pm 0,25$ & $<0,01$ \\
\hline Терміни відновлення рефлексів (діб) & $12,2 \pm 0,17$ & $13,7 \pm 0,18$ & $<0,01$ \\
\hline Тривалість перебування у стаціонарі (діб) & $13,0 \pm 0,27$ & $14,6 \pm 0,24$ & $<0,01$ \\
\hline Білірубін (мкмоль/л) & $160,4 \pm 4,7$ & $191,2 \pm 4,8$ & $<0,01$ \\
\hline Гемоглобін (г/л) & $119,5 \pm 1,8$ & $110,3 \pm 1,6$ & $<0,05$ \\
\hline Середньомолекулярні пептиди (у.о.) & $0,504 \pm 0,014$ & $0,618 \pm 0,029$ & $<0,01$ \\
\hline Аланінамінотрансфераза (UE/I) & $31,2 \pm 4,1$ & $38,1 \pm 3,2$ & $<0,01$ \\
\hline Аспартатамінотрансфераза (UE/I) & $67,1 \pm 3,8$ & $76,1 \pm 4,0$ & $<0,01$ \\
\hline Лактатдегідрогеназа (UE/I) & $565,3 \pm 20,1$ & $625,1 \pm 24,4$ & $<0,01$ \\
\hline
\end{tabular}

періодів $(72,8 \%)$, наявністю ускладнень вагітності (72,8\%), екстрагенітальних захворювань (56,3\%) і патології генітальної системи $(19,6 \%)$, чинників ризику імунізації даної вагітності (44,5\%).

Виконані дослідження виявили напруженість процесів адаптації в новонароджених з гемолітичною хворобою за рахунок розвитку синдрому ендогенної інтоксикації, порушення білірубінового обміну на тлі зниженої функціональної здатності печінки. Отримані результати стали підставою для розробки методики проведення ентеросорбції з використанням ентеросгелю.

Ефективність застосування ентеросгелю оцінювалась за клінічними (тривалість жовтяничного періоду, час перебування в стаціонарі, динаміка неврологічних симптомів) i лабораторними показниками (гемоглобін), біохімічним дослідженням (білірубін, гепатоспецифічні ферменти аланінамінотрансфераза, аспартатамінотрансфераза, лактатдегідрогеназа), показниками синдрому ендогенної інтоксикації (середньомолекулярні пептиди). Обробка отриманих даних проводилась за допомогою методів математичної статистики з обчисленням середніх величин та середньоквадратичних відхилень, а також коефіцієнта Стьюдента.

При легкому перебігу хвороби ентеросгель призначали у дозі 1 г/кг маси тіла на добу. Препарат вводили перорально, через ріжок, у перервах між годуваннями, 3 рази на день протягом 5 діб. Добову дозу препарату розчиняли в 30 мл фізіологічного розчину.

\section{Результати дослідження та їх обговорення}

У хворих основної групи застосування сорбенту було ефективним як за клінічною оцінкою процесу, так і за лабораторними показниками (табл. 1)

При більш тяжкому перебігу гемолітичного процесу, з ознаками токсикозу, проведення ентеросорбції потребувало підвищення дози і часу використання сорбенту в дітей.

При середньотяжкому перебігу захворювання середньодобова доза ентеросгелю становила 1,5 г/кг за добу. Курс лікування в середньому не перевищував 8 діб. Виражений терапевтичний ефект відмічався на 5-ту добу життя. Клінічно це проявлялося підвищенням рухової і рефлекторної активності, зменшенням розмірів печінки та селезінки, відновленням рефлексів періоду новонародженості в більш короткі терміни, скороченням періоду гіпербілірубінемії і часу перебування в стаціонарі. Про зменшення ендогенної інтоксикації, нормалізації білірубінового обміну та функції печінки на фоні використання ентеросгелю свідчили більш низькі показники середньомолекулярних пептидів, білірубіну і печінкових ферментів у крові (табл. 2).

Аналогічна динаміка процесу спостерігалася в дітей із тяжким перебігом захворювання. У цій групі новонароджених ентеросгель призначали в дозі 2 г/кг на добу про- 
Кількість операцій замінного переливання крові та сеансів фототерапії в новонароджених з гемолітичною хворобою

\begin{tabular}{|l|c|c|c|c|}
\hline \multirow{2}{*}{$\begin{array}{c}\text { Група } \\
\text { обстежених } \\
\text { дітей }\end{array}$} & \multicolumn{4}{|c|}{ Кількість сеансів } \\
\cline { 2 - 5 } & \multicolumn{3}{|c|}{ О3ПК } & \multicolumn{1}{c|}{ фототерапія } \\
\cline { 2 - 5 } & абс. & $\%$ & абс. & $\%$ \\
\hline Основна & 27 & 29,3 & 66 & 71,7 \\
\hline Контрольна & 9 & 45,0 & 20 & 100 \\
\hline
\end{tabular}

тягом 9-10 днів. Методика застосування препарату залишалася незмінною. Дітям із відсутністю або пригніченням смоктального рефлексу препарат вводили за допомогою орогастрального зонду.

Проведення ентеральної сорбції за допомогою ентеросгелю дало змогу суттєво зменшити кількість ОЗПК і, тим самим, знизити ризик інфікування новонароджених гемотрансмісивними інфекціями, що є об'єктивним критерієм ефективності та безпеки проведеної терапії. Кількість сеансів фототерапії знизилася на $28,3 \%$.

Використовуючи таку методику, ми не виявили побічних реакцій та ускладнень від застосування ентеросгелю в дітей у ранньому неонатальному періоді.

Проведені дослідження показали, що введення ентеросгелю до комплексної терапії різних форм ГХН підвищує ефективність лікування ізоімунного конфлікту, що характеризується скороченням тривалості жовтяниці, поліпшенням функції печінки, зменшенням активності лактатдегідрогенази та гепатоспецифічних ферментів, ознак білірубінової та ендогенної інтоксикації, більш швидкою елімінацією білірубіну та середньомолекулярних пептидів. Позитивний ефект застосування ентеросгелю в комплексній терапії ГХН підтверджений зменшенням кількості операцій замінного переливання крові та терміну перебування в стаціонарі. Доведено, що ентеросорбція не викликає побічних реакцій та ускладнень i, за даними катамнезу, не чинить негативного впливу на фізичний і психомоторний розвиток дітей.

Введення методу ентеросорбції в комплекс постнатальної терапії гемолітичної хвороби плода і новонародженого дає змогу знизити рівень перинатальної смертності і тяжких уражень центральної нервової системи.

\section{Висновки}

Ентеросорбція є патогенетично обгрунтованим методом лікування гемолітичної хвороби новонароджених.

Ентеросорбція, проведена з перших днів життя у новонароджених 3 ізоімунним конфліктом, сприяє більш сприятливому перебігу патологічного процесу, скороченню термінів перебування в стаціонарі, позитивній динаміці лабораторних показників.

Ентеросорбція є безпечним методом комплексного лікування ГХН, а спосіб введення препарату - простим і доступним.

\section{ЛIТЕРАТУРА}

1. Аряев Н.Л. Диагностика и лечение гемолитической болезни плода и новорожденного / Н.Л. Аряев, А.А. Зелинский, Н.Л. Мерикова. Одесса: Астропринт, 2005. - 262 с.

2. Аряєв Н.Л. Неонатология / Н.Л. Аряєв. - Одесса: Одесский медуниверситет, 2006. - 834 с.

3. Запорожан В.М. Перинатологія / В.М. Запорожан, М.Л. Аряев. Одесса: Одес. держ. мед. ун-т, 2000. - 302 с.

4. Михайлов И.В. Энтеросорбция / И.В. Михайлов // Медицинская помощь. -2002 . - № 5. - С. 47-53.

5. Неонатологія з позиції сімейного лікаря: навч.-метод. посіб. / Т.К. Знаменська, О.М. Ковальова, В.І. Похилько, О.І. Жданович. Київ: Агентство «Стандарт», 2007. - 389 с.
6. Неонатологія: навч. пос. / за ред. Т.Н. Знаменської. Київ: Асоціація неонатологів України. - Макарів: Софія, 2012. -780 c.

7. Педиатрия: национальное руководство: в 2 т. - М.: ГЭОТАР-Медиа, 2009. - Т. 1. - С. 614-686.

8. Педіатрія. Книга I: неонатологія, гематологія, ендокринологія: навч. пос. / за ред. М.Л. Аряєва, Н.В. Котової. - Одеса: Одес. нац. мед ун一, 2011.

9. Шунько Є.Є. Організація надання медичної допомоги новонародженим. Проблеми і перспективи розвитку / Є.Є. Шунько // Актуальні проблеми неонатології : матер. наук. симпозіуму. - Судак, 2006. - C. $2-15$.

\footnotetext{
Клинико-биохимическое обоснование использования энтерособции у новорожденных с гемолитической болезнью

\section{М.Л. Аряев, Л.В. Васильченко, Н.Л. Мерикова, И.М. Шевченко}

Одесский национальный медицинский университет, г. Одесса, Украина

Цель - улучшить результаты терапии гемолитической болезни у новорожденных путем разработки показаний и методики энтеросорбции энтеросгелем с учетом клинико-лабораторных особенностей заболевания.

Пациенты и методы. Обследовано 92 больных с разными вариантами гемолитической болезни (основная группа), которые в комплексной терапии получали энтеросгель. У 37 детей заболевание обусловлено несовместимостью крови матери и ребенка по резус-фрактору, у 55 - конфликтом по АВО-системе. Контрольная группа состояла из 20 детей с разнообразными степенями тяжести гемолитической болезни, у которых энтеросорбция в комплексном лечении не применялась (легкое течение - 10 новорожденных, средней тяжести - 6, тяжелое - 4). Эффективность применения энтеросгеля оценивалась по клиническим (длительность желтушного периода, время пребывания в стационаре, динамика неврологических симптомов) и по лабораторным показателям (гемоглобин), биохимическим исследованиям (билирубин, гепатоспецифические фрерменты - аланинаминотрансфрераза, аспартатаминотрансфераза, лактатдегидрогеназа), показателям синдрома эндогенной интоксикации (среднемолекулярные пептиды). Обработка полученных данных проводилась с помощью методов математической статистики с вычислением средних величин и среднеквадратичных отклонений, а также коэффициента Стьюдента.
} 
Результаты. Установлено, что включение энтеросгеля в комплексную терапию разных фрорм гемолетической болезни повышает эффективность лечения изоимунного конфликта, который характеризуется сокращением длительности желтухи, улучшением функции печени, уменьшением активности лактатдегидрогеназы и гепатоспецифических ферментов, признаков билирубиновой и эндогенной интоксикации, более быстрой элиминацией билирубина и среднемолекулярных пептидов. Позитивный эффект применения энтеросгеля в комплексной терапии подтвержден снижением количества заменимого переливания крови и срока пребывания в стационаре.

Выводы. Энтеросорбция с использованием энтеросгеля не вызывает побочных реакций и осложнений и, по данным катамнеза, не имеет негативного влияния на физическое и психомоторное развитие детей. Включение метода энтеросорбции в комплекс постнатальной терапии гемолитической болезни плода и новорожденного позволяет снизить уровень перинатальной смертности и тяжелых поражений центральной нервной системы.

Ключевые слова: новорожденные дети, гемолитическая болезнь новорожденных, энтеросорбция.

PERINATOLOGIYA I PEDIATRIYA.2015.2(62):86-89; doi10.15574/PP.2015.62.86

Clinical and biochemical enterosorption application among the newborns with hemolytic disease

M.L. Aryayev, L.V. Vasil'chenko, N.L. Merikova, I.M. Shevchenko

Odessa, State Medical University

The article covers the aspects of efficiency and safety of enterosorbtion therapy at newborns with hemolytyc disease. Recived data suggested about the successful results of using of enterosgel at 92 newborns with different forms ofhemolytyc disease. A positive effect in the clinical course of disease and laboratory indicators was shown. a

Key words: children, hemolytyc disease of newborn, enterosorbtion.

Сведения об авторах:

Аряев Николай Леонидович - д.мед.н., проф., чл.-корр. НАМН Украины, зав. каф. педиатрии №1 Одесского НМУ.

Адрес: г. Одесса, Валиховский пер., 2; тел. (048) 740-52-49.

Васильченко Лилия Викторовна - к.мед.н., ассистент каф. педиатрии №3 с последипломной подготовкой

Одесского НМУ. Адрес: г. Одесса, Валиховский пер., 2; тел. (048) 740-52-49.

Мерикова Неонила Леонтьевна - к.мед.н., доц. каф. педиатрии №3 с последипломной подготовкой

Одесского НМУ. Адрес: г. Одесса, Валиховский пер., 2; тел. (048) 740-52-49.

Шевченко Игорь Михайлович - к.мед.н., доц. каф. педиатрии №1

Наукове звання: кандидат медичних наук, доцент кафедри педіатрії № 1 Одесского НМу.

Адрес: г. Одесса, Валиховский пер., 2; тел. (048) 740-52-49.

Статья поступила в редакцию 30.04.2015 г. 


\title{
С.0. Ізюмець1, І.В. Галактіонова², О.І. Ізюмець³ Перинатальна патологія у формуванні атлантичної хвороби новонароджених
}

\author{
1 Вінницький обласний ендокринологічний диспансер, м. Вінниця, Україна \\ 2 Вінницька обласна дитяча лікарня, м. Вінниця, Україна \\ з Вінницький національний медичний університет імені М.І. Пирогова, м. Вінниця, Україна
}

PERINATOLOGIYA I PEDIATRIYA.2015.2(62):90-93;doi10.15574/PP.2015.62.90

Мета - удосконалити ранню діагностику ушкоджень шийного відділу хребта, детально вивчити причини та особливості клінічного перебігу. Пацієнти та методи. Обстежено 35 новонароджених дітей, серед яких у віці 4-10 діб було 12 (34,2\%) дітей, 11-20 діб - 18 (51,4\%) дітей, 21-30 діб $5(14,2 \%)$ дітей. Хлопчиків було $21(60,0 \%)$, дівчаток - $14(40,0 \%)$. Оцінка стану новонароджених за шкалою Апгар показала, що 43\% обстежених дітей мали ассріксію до 7 балів, із них тяжка зустрічалась у 13\%, помірна - у 87\% новонароджених. 3 метою діагностики пошкоджень шийного відділу хребта новонародженим проведено рентгенологічне обстеження в таких термінах (залежно від тяжкості загального стану): на 1-7-му добу 20\%; на 8-28-му добу — 77\%; на 29-ту добу і пізніше - 3\%.

Результати. Ротаційний підвивих С1 зустрічається часто - близько 85,7\% (за даними нашого дослідження), а діагностується дуже рідко. Рання діагностика ушкоджень шийного відділу хребта дає змогу виявити патологію досить часто.

Висновки. Ретельний збір анамнезу щодо виявлення факторів ризику та клінічна настороженість сприяють ранньому виявленню ушкоджень шийного відділу хребта (а саме ушкоджень атланта).

Ключові слова: новонароджені, пологові пошкодження хребта, діагностика.

\section{Вступ \\ $\Pi$} ологові ушкодження шийного відділу хребта та спинного мозку є однією з найменше вивчених проблем у неонатології, які призводять до розвитку нестабільності краніо-вертебральної зони та характеризуються найчастіше хронічним динамічним підвивихом в атлантоокципітальному та атланто-аксіальному суглобах. Пологова травма хребта виникає у 2-3 рази частіше, ніж внутрішньочерепна. Частота пологових травм становить 2-7 на 1000 живонароджених. За дослідженнями Михайлова М.К. (1983) та Юхнової О.М. (1998), пологова травма шийного відділу хребта становить 85,5\% серед усіх пологових травм. У 45-51\% виявляється саме ротаційний підвивих. Ушкодження шийного відділу спинного мозку у 75\% поєднується 3 природними пологами при проходженні пологовими шляхами голівки дитини (особливо у першороділь).

Ротаційний підвивих першого шийного хребця це патологічний поворот першого шийного хребця направо чи наліво. Зміщення відбувається, як правило, одночасно в декількох площинах. Найбільш розповсюджений варіант - коли перший шийний хребець повертається та нахиляється направо, а другий - наліво. При цьому виникає фіксація між першим хребцем і надвиростком потиличної кістки справа.

Для розуміння механізмів пошкодження спинного та головного мозку новонародженого необхідно враховувати деякі особливості будови шийного відділу хребта в новонароджених: у поперечних відростках п'яти шийних хребців через отвори проходять хребтові артерії, які постачають кров в окремі відділи головного та спинного мозку. При повороті голови, притягуванні за голівку, перегинах шиї відбувається порушення кровообігу у вертебро-базилярному басейні. Новонароджена дитина має також відмінну від дорослої кісткову систему. Вона відрізняється гнучкістю, необхідною для того, щоб без травм пройти по досить вузьких пологових шляхам жінки. Саме через це виникають прецеденти, коли при неправильному веденні пологів або при інших інтранатальних причинах відбуваються пологові травми, які призводять до розтягнення шийних хребців.
Каскад патологічних процесів при зміщенні першого шийного хребия:

- здавлення хребтової артерії погіршує кровопостачання стовбура мозку, мозочка, вестибулярного апарату, потиличної (зорової) кори;

- подразнення симпатичних сплетень хребтової артерії порушує регуляцію мозкового кровотоку;

- порушення мікроциркуляції та венозного відтоку 3 порожнини черепа веде до підвищення внутрішньочерепного тиску та порушення трофіки нервової тканини;

- перерозподіл навантаження на суглоби потиличного сегмента провокує розвиток артрозу, а рефлекторний спазм м'язів веде до розвитку міофіброзу, м'язово-тонічних болей та синдрому хребтової артерії;

- «скам'янілі» м'які тканини потиличного сегмента травмують нерви, що веде до появи неврологічної симптоматики.

Тому отримана інтранатально травма верхньошийного відділу хребта викликає не тільки зону враження, але й призводить до каскадного розвитку ушкоджень на рівні органів та систем безпосередньо або вторинно за рахунок порушення кровопостачання, іннервації, трофіки та в цілому на рівні всього організму, що призводить до дезадаптації й порушення нормального розвитку дитини.

Незважаючи на розвиток сучасних медичних технологій та створення нових лікарських препаратів, діти все ж таки мають порушення постави, скаржаться на головний біль, підвищену збудливість, погано переносять фізичні та розумові навантаження.

Більш сучасна трактовка старих, часто загальновідомих дитячих проблем, в основі яких може бути одна причина травма або вада розвитку атланта (C1) - називається атлантичною хворобою в дітей перших років життя (атлантична патологія) і вона може переслідувати людину протягом усього життя. Пізнє виліковування без наслідків можливе, якщо діагностика та корекція проведені не пізніше 4 років, в іншому випадку патологічний процес закріпиться та сам 
Ступінь тяжкості ушкодження шийного відділу хребта

Таблиия

\begin{tabular}{|c|c|c|}
\hline Ступінь & Кут, & 3начення «Х» \\
\hline $\mathrm{I}$ & $5-10^{\circ}$ & $0,08-0,17$ \\
\hline $\mathrm{II}$ & $11-15^{\circ}$ & $0,17-0,26$ \\
\hline $\mathrm{II}$ & $>15^{\circ}$ & $>0,26$ \\
\hline
\end{tabular}

стане причиною подальших розладів. Тому вкрай необхідна своєчасна діагностика та лікування захворювань хребта.

Діагностика

Рентгенологічні дослідження виконувались на апараті Sihlouette VR. Новонародженим з клінічними ознаками пологової травми верхньо-шийного відділу виконувалась бічна та трансоральна рентгенографія в горизонтальному положенні. Тяжкість пошкоджень визначалась шляхом вимірювань і розрахунків параметрів відповідно патенту «Спосіб діагностики ступеня тяжкості ураження верхньошийного відділу хребта при пологовій травмі», реєстр №157/34/11. Нами оцінювались співвідношення С1-С2 на бічній рентгенограмі - наявність кута, що утворюють проведені через хребці вісі. На трансоральній рентгенограмі оцінювалась асиметрія бічних мас С1 відносно зубоподібного відростка С2 - у міліметрах, а кут, який утворюють суглобні поверхні у бічних атланто-аксилярних суглобах, у градусах. Розраховувався індекс Х, що відповідає тангенсу кута, який утворюється між суглобними поверхнями і свідчить про ушкодження міжхребцевого диска (табл.).

За даними літератури, пошкодження шийного відділу хребта найбільш часто виникає у крупних плодів (72\%), при тазовому передлежанні (65\%), і значно рідше (17\%) при головному передлежанні без використання акушерських прийомів чи кесаревого розтину. До особливої групи ризику належать недоношені новонароджені, використання ручних рододопоміжних прийомів або щипців, тривалий безводний проміжок, слабкість пологової діяльності або іiі стимуляція, обвиття плода пуповиною, стрімкі пологи. Розташування плода в матці також відіграє значну роль, оскільки лицьове та поперечне положення є умовами, за яких нормальне родорозрішення неможливе. Також мають значення вроджені патології розвитку хребта. В подальшому у таких новонароджених розвивається: перинатальна енцефалопатія травматичного генезу (44\%), порушення мозкового кровообігу у вертебро-базилярному басейні (15\%), підвищення внутрішньочерепного тиску (12,6\%), парез діафрагми (6\%), кривошия (5\%).

Клінічними передвісниками пологової травми хребта є: деформація черепа (макро-, мікрокранія), кривошия, загальна слабкість, в'ялість м'язів (гіпотонія або атонія) або гіпертонус, порушення рухової активності (гіподинамія або атонія), акушерський параліч, судомна готовність або судоми, безпричинний плач або стурбованість, запрокидування голови, страждальний вигляд обличчя, порушення психомоторного розвитку.

На розтягнення шийних хребців у постнатальному періоді вказують такі клінічні симптоми: горизонтальний ністагм; зниження або відсутність вроджених рефлексів; плач без причини (через набряк тканин) - «кричущі діти» (плачуть при їзді в машині або в колясці, або при зміні положення дитини чи взятті її на руки); кривошия (обумовлена рефлекторною м'язовою напругою у відповідь на порушення нормального співвідношення анатомічних структур. Нахил голови в один бік є вимушеним положенням, яке полегшує больовий синдром. Дитина не може повернути голову в який-небудь бік, плаче та хви- люється при цьому. Лежить завжди повернувши голову в один бік, при годуванні груддю добре висмоктує з одного боку та відмовляється від іншої груді); проблеми із самостійним вживанням їжі - часті зригування (пов'язані $з$ підвищенням тонусу діафрагми, так як іiі іннервація походить із шийного відділу), мотання головою в перервах між смоктанням грудей; функціональні розлади (коліки, здуття живота, проблеми 3 ковтанням); асиметрія голови (різниця між правою та лівою половинами черепа, різна величина очних щілин, по-різному відстовбурчені або прижаті вушка); тахікардія.

Діти раннього віку (до 3 років) часто засмучують своїх батьків поганим сном, частими зригуваннями, постійним занепокоєнням та криком, в'ялим смоктанням груді, зниженням м'язового тонусу, затримкою психомоторного розвитку. Можливий розвиток гідроцефалії, бронхіальної астми, екземи, харчової алергії, нейродерміту, деформації хребта, епілепсії, анемії. Якщо діагноз не був встановлений у пологовій залі або на 1-му місяці життя дитини, то неврологічна симптоматика починає проявлятися дещо пізніше. У них може розвиватися бронхіальна астма, екзема, харчова алергія, нейродерміт, деформації хребта, епілепсія, анемія.

У дітей старших вікових груп виникає головний біль нез'ясованої етіології, головокружіння, підвищена стомленість, сколіоз, вегето-судинна дистонія (що включає нестабільність артеріального тиску, відчуття серцебиття, метеозалежність, запаморочення, підвищену пітливість, проноси, здуття живота, субфебрилітет, порушення терморегуляції, дисфункцію жовчовивідних шляхів, енурез), зниження пам'яті, зменшення гостроти зору, порушення загальної та мілкої моторики, можливий синдром дефіциту уваги, тяжкість із концентрацією уваги, проблеми 3 навчанням та соціальною адаптацією в дитячому колективі. Порушення росту та розвитку опорно-рухового апарату виникають через збій регуляції та порушення формування фізіологічних вигинів хребта.

Mema роботи - удосконалити ранню діагностику ушкоджень шийного відділу хребта, детально вивчити причини та особливості клінічного перебігу.

\section{Матеріали та методи дослідження}

Відповідно до мети нами обстежено 35 новонароджених дітей, серед яких у віці 4-10 діб було 12 (34,2\%) дітей, 11-20 діб - 18 (51,4\%) дітей, 21-30 діб - 5 (14,2\%) дітей. Хлопчиків було 21 (60,0\%), дівчаток - 14 (40,0\%). Найбільш поширеними факторами ризику були недоношеність (19\%), обвиття плоду пуповиною (18\%), слабкість пологової діяльності або їі стимуляція (12\%) та стрімкі пологи (10\%). Рідше (по 7,0\% на кожен) зустрічались кесарів розтин, лицьове передлежання, поперечне положення і затяжний перебіг пологів. Частота утрудненого виведення голівки та плечиків, мимовільних пологів, тазового та сідничного передлежання, тривалого безводного проміжку, використання ручних рододопоміжних прийомів або вакуум-екстракції, передчасних пологів i переношеної вагітності коливалась у межах 1-5\%. 
Оцінка стану новонароджених за шкалою Апгар показала, що 43\% обстежених дітей мали асфіксію до 7 балів, із них тяжка зустрічалась у 13\%, помірна - у $87 \%$ новонароджених.

3 метою діагностики пошкоджень шийного відділу хребта новонародженим проводилось рентгенологічне обстеження в таких термінах (залежно від тяжкості загального стану): на 1-7-му добу $-20 \%$; на $8-28$-му добу $-77 \%$; на 29 -ту добу і пізніше $-3 \%$.

Більшість обстежених новонароджених у стаціонарі знаходились 3 приводу краніоспінальної пологової травми (42\%) та перинатальної енцефалопатії гіпоксично-ішемічного генезу (39\%), рідше - перинатальної енцефалопатії гіпоксично-травматичного генезу (19\%).

$\mathrm{y}$ новонароджених дітей, направлених на рентгенологічну діагностику, були діагнози, не пов'язані з пологовою травмою (30\%), але вони мали високі фактори ризику щодо пологової травми (недоношені новонароджені - $42 \%$, обвиття пуповиною навколо тулуба $-25 \%$, індуковані пологи $17 \%$, кесарів розтин - 8\%, передчасні пологи - 8\%).

При спостереженні в динаміці за перебігом клінічної картини новонароджених дітей відмічались такі клінічні ознаки: горизонтальний ністагм, зниження або відсутність вроджених рефлексів, кривошия, часті зригування, мотання головою в перервах між смоктанням грудей, порушення харчування (коліки, здуття живота, проблеми 3 ковтанням), асиметрія голови та різна величина очних щілин, по-різному відстовбурчені або прижаті вушка.

Усім новонародженим проводилася нейросонографія (НСГ), яка у 1/3 новонароджених мала менші чи більші ступені відхилення пошкоджень структур головного мозку.

\section{Результати дослідження та їх обговорення}

Серед обстежених новонароджених, в яких спостерігалися вищезгадані фактори ризику, методом рентгенографії ротаційний підвивих С1 хребця виявлено у 30 (85,7\%) дітей. Серед них підвивих С1 з ураженням міжхребцевого диска встановлено у 25 (83\%) дітей, без ураження міжхребцевого диска - у 5 (17\%) дітей. Підвивих С1 з двобічним ураженням міжхребцевого диска виявлено у 24 (96\%) дітей. Новонароджені були розділені на 2 групи: 3 уражен- ням міжхребцевого диска однакового ступеня тяжкості з обох сторін - 14 (56\%) дітей, різного ступеня тяжкості справа та зліва - 10 (40\%) дітей.

Серед усіх 35 обстежених новонароджених дітей лише в 5 дітей рентгенологічна діагностика 3 приводу ушкодження шийного відділу хребта була негативною.

\section{Висновки}

Ротаційний підвивих С1 зустрічається часто - близько 85,7\% (за даними нашого дослідження), а діагностується дуже рідко. Рання діагностика ушкоджень шийного відділу хребта дає змогу виявити патологію досить часто.

Ретельний збір анамнезу щодо виявлення факторів ризику та клінічна настороженість сприяють ранньому виявленню ушкоджень шийного відділу хребта (а саме ушкоджень атланта).

Рекомендаціі

Профілактика ушкоджень атланта має включати: планування вагітності заздалегідь, усуваючи захворювання та оптимізуючи спосіб життя; нормальне харчування та уникнення інфекційних хвороб під час очікування дитини; отримання грамотної медичної допомоги під час вагітності; уникнення надмірної кількості медичних процедур та маніпуляцій під час вагітності та пологів; своєчасна медична допомога при пологах і після них; грамотні дії акушерів; спостереження за новонародженим після пологів; комплексний підхід до відновлення здоров'я дитини.

Своєчасна рання діагностика (пальпаторно оцінюється положення та рухливість С1, рентгенологічна діагностика 3 урахуванням факторів ризику та особливостей клініки). Рентгенологічне обстеження є пріоритетом інструментальної діагностики пологової травми хребта, однак воно дає можливість виявити лише кісткові пошкодження, тоді як спинний мозок, його оболонки та хребтові артерії не візуалізуються.

У ранньому неонатальному періоді новонародженим із ризиком ушкоджень хребта необхідно проводити огляд шийного відділу хребта дитячим травматологом (пальпаторна діагностика).

Сума цих заходів і є реалізацією системного підходу до лікування патологій атланта - маленької кісточки, від якої може залежати життя.

\section{ЛITЕРАТУРА}

1. Акберов Р.Ф. Комплексная клинико-рентгенологическая диагностика аномалий развития краниовертебральной зоны и позвоночника у детей, подростков и взрослых / Р.Ф. Акберов, М.К. Михайлов, И.Р. Хабибуялин // Вертеброневрология. 1999. - T. 6, № 1-2. - С. 65-72.
2. Михайлов М.К. Рентгенодиагностика родовых повреждений позвоночника / М.К. Михайлов. - Казань, 1983. - 120 с.

3. Юхнова О.М. Причины нестабильности у детей и подростков / О.М. Юхнова, В.Ф. Косыгин, Г.А. Пономарева // Вертебрология проблемы, поиски, решения. - 1998. - № 2. - С. 172-174.

\section{Перинатальная патология в формировании атлантической болезни новорожденных С.А. Изюмец ${ }^{1}$, И.В. Галактионова2, О.И. Изюмец ${ }^{3}$}

1 Винницкий областной эндокринологический диспансер, г. Винница, Украина

2 Винницкая областная детская клиническая больница, г. Винница, Украина

з Винницкий национальный медицинский университет имени М.И. Пирогова, г. Винница, Украина

Цель - усовершенствовать раннюю диагностику повреждений шейного отдела позвоночника, детально изучить причины и особенности клинического течения.

Пациенты и методы. Обследовано 35 новорожденных детей, среди которых в возрасте 4-10 суток было 12 (34,2\%) детей, 11-20 суток - 18 (51,4\%) детей, 21-30 суток - 5 (14,2\%) детей. Мальчиков было 21 (60,0\%), девочек - 14 (40,0\%). Оценка состояния новорожденных по шкале Апгар показала, что 43\% обследованных детей имели асфиксию до 7 баллов, из них тяжелая встречалась у 13\%, умеренная — у $87 \%$ новорожденных. С целью 
диагностики повреждений шейного отдела позвоночника новорожденным проведено рентгенологическое обследование в таких сроках (в зависимости от тяжести общего положения): на 1-7-е сутки - 20\%; на 8-28-е сутки - 77\%; на 29-е сутки и позже - 3\%.

Результаты. Ротационный подвывих С1 встречается часто — около 85,7\% (по данным нашего исследования), а диагностируется очень редко. Ранняя диагностика повреждений шейного отдела позвоночника позволяет выявить патологию достаточно часто.

Выводы. Тщательный сбор анамнеза относительно выявления факторов риска и клиническая настороженность способствуют раннему выявлению повреждений шейного отдела позвоночника (а именно повреждений атланта).

Ключевые слова: новорожденные, родовые травмы позвоночника, диагностика

PERINATOLOGIYA I PEDIATRIYA.2015.2(62):90-93;doi10.15574/PP.2015.62.90

Perinatal pathology as the base for atlantic disease of neonates

S. O. Izumec, I.V. Galaktionova, 0.I. Izumec

N.I. Pirogov Vinnitsa National Medical University, Ukraine

Vinnitsa regional children hospital

Vinnitsa regional endocrinological dispensary

Generic damage of the cervical spine and spinal cord are the most neglected problems of childhood problems, the frequency of which is about $19,3 \pm 0,6 \%$. The lack of clinical suspicion in the presence of risk factors in traumatic obstetric history, lack of a clear specific clinical picture in acute as well as its variability prevents early diagnosis of birth injuries of the spine. X-ray method of diagnosis is the priority method of imaging lesions of the spine and spinal cord. Rotary subluxation of $\mathrm{C} 1-\mathrm{C} 2$ lead to violations not only at the level of damage, and the whole body.

Key words: newborn, maternity spine injury, diagnosis.

Сведения об авторах:

Изюмец Светлана Александровна - врач-гинеколог-эндокринолог Винницкого областного эндокринологического диспансера. Тел. (093) 254-85-64.

Галактионова Инна Васильевна - врач детский невропатолог Винницкой областной детской клинической больницы.

Тел. (067) 509-47-14

Изюмец Ольга Ивановна - к.мед.н., доц. каф. детских болезней №2 Винницкого НМУ

им. М.И. Пирогова, Винницкая областная детская клиническая больница. Тел. (093) 254-85-64.

Статья поступила в редакцию 30.04.2015 г. 


\title{
УДК 618.5:616.24-008.4-053.31
}

\section{С.О. Ізюмець1, О.І. Ізюмець², І.В. Галактіонова3, Т.В. Мурашко2 Роль перинатальної патології у виникненні аспіраційного синдрому в новонароджених, його діагностика}

\author{
1 Вінницький обласний ендокринологічний диспансер, м. Вінниця, Україна \\ 2 Вінницький національний медичний університет імені М.І. Пирогова, м. Вінниця, Україна \\ з Вінницька обласна дитяча клінічна лікарня, м. Вінниця, Україна
}

PERINATOLOGIYA I PEDIATRIYA.2015.2(62):94-96;doi10.15574/PP.2015.62.94

\begin{abstract}
Мета - удосконалити діагностику, зокрема, рентгенологічну візуалізацію для встановлення ступеня тяжкості аспіраційного синдрому в новонароджених із перинатальним пошкодженням центральної нервової системи.

Пацієнти та методи. Обстежено 30 новонароджених, із було по 50\% хлопчиків і дівчаток. Усі діти були з перинатальним пошкодженням центральної нервової системи, але залежно від супутньої патології вони були розділені на групи. Перша група - 15 новонароджених із гіпоксично-ішемічним пошкодженням центральної нервової системи та аспіраційним синдромом (дистрес-синдромом тяжкого ступеня за Downes). Друга група — 10 новонароджених із гіпоксично-ішемічним пошкодженням центральної нервової системи без супутньої патології у віці 4-14 діб. Третя група 5 новонароджених із гіпоксично-ішемічним пошкодженням центральної нервової системи з іншою супутньою патологією. Усім новонародженим проведено рентгенографрію органів грудної клітки; у віці 1-3 доби - 5 новонародженим; 4-7 діб - 17 новонародженим; 8-23 доби 8 новонародженим. Використано патент на корисну модель «Спосіб діагностики ступеня тяжкості аспіраційного синдрому в новонароджених із перинатальним ураженням ЦНС», яку здійснюють шляхом проведення рентгенограсрії органів грудної клітки.

Результати. За допомогою рентгенологічного обстеження органів грудної клітки в новонароджених із перинатальним пошкодженням центральної нервової системи I ступінь аспіраційного синдрому виявлено у 16 (53,3\%) новонароджених, II ступінь - у 12 (40\%) дітей, III ступінь - у 2 (6,7\%) малюків. При більш ранній рентгенологічній діагностиці (до 3 діб) встановлено легкий ступінь аспіраційного синдрому без ускладнень.

Висновки. Визначення рентгенологічних критеріїв ступеня тяжкості аспіраційного синдрому дають можливість більш об'єктивно оцінити стан новонародженого. Рентгенологічні критерії ступенів тяжкості аспіраційного синдрому дозволяють не лише встановити правильний діагноз, але й контролювати ефективність своєчасно проведеного лікування і попередити розвиток ускладнень.

Ключові слова: новонароджені, аспіраційний синдром, рентгенографія органів грудної клітини, перинатальне пошкодження цнС.
\end{abstract}

\section{Вступ}

А спіраційний синдром - це патологія, яка проАявляється респіраторним дистрес-синдромом, що характеризується обструкцією дихальних шляхів унаслідок потрапляння в трахео-бронхіальне дерево плода навколоплідних вод.

За офіційними статистичними даними, аспірація навколоплідних вод у структурі основних причин загибелі плода посідає 5-те місце поряд із пологовим травматизмом. Водночас, серед причин ранньої неонатальної смертності новонароджених синдром масивної аспірації займає 7 -е місце (2,5\%). Тенденція до зниження відмічається при запровадженні нових моніторних методів контролю стану плоду під час пологів, а також збільшення частоти кесаревого розтину, що виконується за різними показаннями Середня частота аспіраційного синдрому, за даними різних авторів, коливається у межах 2-3\%, тоді як пологи 3 меконіальними навколоплідними водами спостерігаються у $9-15 \%$ породіль. Рання діагностика та профілактика аспіраційного синдрому залишаються резервом для зменшення показників перинатальної захворюваності та смертності.

Провідною патогенетичною ланкою розвитку аспіраційного синдрому в новонароджених є гостра чи прогресуюча хронічна гіпоксія плоду. Здавлення судин пуповини чи навіть короткочасне їх стиснення супроводжується гіпоксичним станом плода, що викликає спазм мезентеріальних судин, підвищення перистальтики кишечнику та відходження меконію. Водночас гіпоксія плода виступає дихальним стимулом, що викликає збільшення частоти, амплітуди дихальних рухів і появу патологічних форм дихальних рухів, при яких частинки меконію потрапляють у дихальні шляхи, викликаючи релаксацію гладком'язової структури трахеї шляхом дії проміжних продуктів обміну циклооксигенази, білків та жирних кислот. Подальша дія частинок меконію викликає хімічні та морфологічні зміни легеневої тканини, обструкцію дихальних шляхів, порушення газообміну i, як наслідок, тяжкі респіраторні розлади, спазм судин та зміни мікроциркуляції в легенях, розвиток легеневої гіпертензії та екстрапульмональних шунтів. За останніми літературними даними, частинки меконію в малих розведеннях не мають токсичного впливу на пневмоцити 2-го порядку, а компоненти меконію, такі як протеїни, навіть збільшують секрецію сурфактанту, що пояснює часті недіагностовані випадки аспірації меконіальними аспіраційними водами.

Перинатальними факторами ризику для розвитку аспіраційного синдрому в новонароджених є захворювання вагітних (гестози, серцево-судинні та хронічні легеневі захворювання, цукровий діабет, хвороби нирок), резусконфлікт, а також пізній вік матері, що спричиняють розвиток фетоплацентарної недостатності різного ступеня тяжкості. До інтранатальних факторів ризику аспірації навколоплідними водами належать переношування вагітності більше 40 тижнів, пізні пологи, аномалії пологової діяльності (слабкість або дискордантна), тривалий перебіг пологів у жінок із хронічною гіпоксією плода, тривале та нераціональне використання утеротонічних засобів у пологах при вже порушеному стані плода, крупний плід, обвиття пуповиною.

Клінічні прояви аспіраційного синдрому в постнатальному періоді. Залежно від кількості аспірованих мас може настати несподівана смерть, колапс або найвищий ступінь диспное (дистрес-синдром). При незначній кількості аспірованої рідини розвиваються клапанні механізми або стани закупорки бронхіального дерева 3 подальшими мікроателектазами. Якщо способи видалення аспірату ефективні, то дитина деякий час бліда, 3 помірними порушеннями дихання, у протилежних випадках прослуховується жорстке дихання з крупнопухирцевими хрипами та з місцями послабленого чи відсутнього дихання. Можливий розвиток ускладнень у вигляді дисперсної вогнищевої аспіраційної пневмонії, зливної чи навіть абсцедуючої, іноді з реакцією з боку плеври чи 3 емпіємою, також може відбуватися процес перетравлення 
Рентгенологічні критерії діагностики ступеня тяжкості аспіраційного синдрому

Таблиия 1 в новонароджених із перинатальним пошкодженням центральної нервової системи

\begin{tabular}{|l|c|}
\hline \multicolumn{1}{|c|}{ Ознака } & Hopмa \\
\hline Стан правого купола діафрагми & Ha рівні V-VI ребра \\
\hline Величина кардіо-торакального індексу (КТІ) & 49-54\% \\
\hline Вогнищеві та інфрільтративні зміни & Відсутні \\
\hline
\end{tabular}

Ступені тяжкості аспіраційного синдрому

Таблиия 2

\begin{tabular}{|c|c|c|c|}
\hline Ознака & І ступінь & II ступінь & III ступінь \\
\hline Стан правого купола діафрагми & 6 ребро & 7 ребро & 8 ребро \\
\hline KTI & $55-57 \%$ & $58-60 \%$ & понад $61 \%$ \\
\hline $\begin{array}{l}\text { Вогнищеві } \\
\text { та інфільтративні зміни }\end{array}$ & $\begin{array}{c}\text { Вогнищеві тіні } \\
\text { у верхньомедіальних } \\
\text { відділах }\end{array}$ & $\begin{array}{l}\text { Тіні в медіальних } \\
\text { відділах легень }\end{array}$ & $\begin{array}{c}\text { Вогнищеві тіні на всьому } \\
\text { протязі легень. Симптом } \\
\text { «снігової бурі» }\end{array}$ \\
\hline
\end{tabular}

легеневої тканини аспірованим шлунковим соком (хімічний пневмоніт).

Mema роботи - удосконалити діагностику, зокрема, рентгенологічну візуалізацію для встановлення ступеня тяжкості аспіраційного синдрому в новонароджених із перинатальним пошкодженням центральної нервової системи (ЦНС).

\section{Матеріали та методи дослідження}

Відомим способом діагностики аспіраційного синдрому в новонароджених є клініко-рентгенологічні паралелі. Недоліки способу пов'язані з використанням суб'єктивних ознак, що знижують точність діагностики захворювання і залежать від кваліфікації лікаря (шкала Downes), якості рентгенограм.

Нами використано патент на корисну модель «Спосіб діагностики ступеня тяжкості аспіраційного синдрому в новонароджених із перинатальним ураженням ЦНС», яку здійснюють шляхом проведення рентгенографії органів грудної клітки, визначаючи критерії, вказані в таблиці 1.

Серед обстежених 30 новонароджених було по 50\% хлопчиків і дівчаток. Усі діти були з перинатальним пошкодженням ЦНС, але залежно від супутньої патології вони були розділені на групи. Перша група 15 новонароджених із гіпоксично-ішемічним пошкодженням ЦНС та аспіраційним синдромом (дистрес-синдромом тяжкого ступеня за Downes), який відмічався у 4 дітей у віці до 3 діб, у 8 дітей у віці 4-7 діб і в 3 дітей у віці 8 діб і більше. Серед них 3 новонароджені перенесли хімічний пневмоніт (через 48 год.), а у 3 - розвинулася аспіраційна пневмонія (на 3-ю добу). Друга група 10 новонароджених із гіпоксично-ішемічним пошкодженням ЦНС без супутньої патології у віці 4-14 діб. Третя група - 5 новонароджених із гіпоксично-ішемічним пошкодженням ЦНС 3 іншою супутньою патологією, а саме: 1 новонароджений у віці 23 доби з краніоспінальною пологовою травмою, 1 новонароджений у віці 1 доби 3 внутрішньоутробною пневмонією, 1 новонароджений у віці 6 діб зі стигмою дизембріогенезу ротової порожнини (розщілина верхньої губи, м'якого та твердого піднебіння, носового ходу зліва), 1 новонароджений у віці 6 діб із неонатальною жовтяницею.

Усім новонародженим проведено рентгенографію органів грудної клітки; у віці 1-3 доби - 5 новонародженим; 4-7 діб - 17 новонародженим; 8-23 доби - 8 новонародженим.

\section{Результати дослідження та їх обговорення}

У І групі дітей за результатами рентгенографії у віці 1-3 доби I ступінь аспіраційного синдрому встановлено у 2 новонароджених без аспіраційної пневмонії, II ступінь - у 2 малюків (в 1 новонародженого з аспіраційною пневмонією та 1 новонародженого без неї); III ступінь не виявлено в жодної дитини. У малюків у віці 4-7 діб I ступінь аспіраційного синдрому діагностовано у 2 дітей (в 1 новонародженого з аспіраційною пневмонією та 1 новонародженого без неї), II ступінь у 6 дітей (у 2 новонароджених з аспіраційною пневмонією та 4 новонароджених без неї), III ступінь аспіраційного синдрому не виявлено в жодної дитини. У дітей у віці 8 діб і більше I ступінь аспіраційного синдрому встановлено у 2 новонароджених без аспіраційної пневмонії, II ступінь - в 1 новонародженого з аспіраційною пневмонією; III ступінь не виявлено в жодного новонародженого.

У II групі новонароджених (із гіпоксично-ішемічним пошкодженням ЦНС без супутньої патології) за результатами рентгенографії I ступінь аспіраційного синдрому встановлено у 6 дітей (у 2 новонароджених з аспіраційною пневмонією та 4 малюків без неї); II ступінь - у 2 дітей 3 аспіраційною пневмонією; III ступінь - у 2 новонароджених з аспіраційною пневмонією.

У III групі дітей (із гіпоксично-ішемічним пошкодженням ЦНС з іншою супутньою патологією) за результатами рентгенографії I ступінь аспіраційного синдрому встановлено в 4 новонароджених, II ступінь - в 1 дитини.

\section{Висновки}

За допомогою рентгенологічного обстеження органів грудної клітки в новонароджених із перинатальним пошкодженням ЦНС I ступінь аспіраційного синдрому виявлено у 16 (53,3\%) новонароджених, II ступінь у 12 (40\%) дітей, III ступінь - у 2 (6,7\%) малюків.

При більш ранній рентгенологічній діагностиці (до 3 діб) встановлено легкий ступінь аспіраційного синдрому без ускладнень.

Визначення рентгенологічних критеріїв ступеня тяжкості аспіраційного синдрому дають можливість більш об'єктивно оцінити стан новонародженого.

Рентгенологічні критерії ступенів тяжкості аспіраційного синдрому дозволяють не лише встановити правильний діагноз, але й контролювати ефективність своєчасно проведеного лікування і попередити розвиток ускладнень. 


\section{Рекомендаціі}

Для правильного встановлення діагнозу та адекватного лікування необхідно використовувати рентгенологічні критерії оцінки ступеня тяжкості аспіраційного синдрому.
Слід враховувати перинатальні фактори ризику щодо розвитку аспіраційного синдрому та своєчасно направляти новонароджених на рентгенологічне обстеження для встановлення ступенів тяжкості аспіраційного синдрому.

\section{ЛІТЕРАТУРА}

1. Дементьева Г.М. Актуальные проблемы пульмонологии новорожденных / Г.М. Дементьева, И.И. Рюмина, М.В. Кушнарева // Российский вестник перинатологии и педиатрии. 2001. - № 5. - С. 14-19.

2. Детская пульмонология / под ред. Н.Л. Аряева. Київ: Здоров'я, 2005. - С. 155-159.

3. Михельсон В.А. Интенсивная терапия аспирационного синдрома у новорожденных / В.А. Михельсон, В.А. Гребен- ников, И.С. Замлынская // Педиатрия. - 1998. № 5. - С. $70-74$.

4. Патент № 29692 Україна, МПК (2006) А 61В6100 Спосіб діагностики ступеня тяжкості аспіраційного синдрому в новонароджених з перинатальним ураженням ЦНС.

5. Рентгенодіагностика гострих захворювань органів дихання у дітей: навч. пос. / за ред. І.О. Крамного. - Харків: Крокус, 2006. - C. $120-122$

Роль перинатальной патологии в возникновении аспирационного синдрома у новорожденных, его диагностика

С.А. Изюмец1, О.И. Изюмець², И.В. Галактионова3, Т.В. Мурашко2

1 Винницкий областной эндокринологический диспансер, г. Винница, Украина

2 Винницкий национальный медицинский университет имени М.И. Пирогова, г. Винница, Украина

3 Винницкая областная детская клиническая больница, г. Винница, Украина

Цель - усовершенствовать диагностику, в частности, рентгенологическую визуализацию для установления степени тяжести аспирационного синдрома в новорожденных с перинатальным повреждением центральной нервной системы.

Пациенты и методы. Обследованы 30 новорожденных, из них было по 50\% мальчиков и девочек. Все дети были с перинатальным повреждением центральной нервной системы, но в зависимости от сопутствующей патологии они были разделены на группы. Первая группа 15 новорожденных с гипоксически-ишемическим повреждением центральной нервной системы и аспирационным синдромом (дистресссиндромом тяжелой степени за Downes). Вторая группа - 10 новорожденных с гипоксически-ишемическим повреждением центральной нервной системы без сопутствущей патологии в возрасте 4-14 суток. Третья группа - 5 новорожденных с гипоксически-ишемическим повреждением центральной нервной системы с другой сопутствующей патологией. Всем новорожденным проведено рентгенографию органов грудной клетки; в возрасте 1-3 суток - 5 новорожденным; 4-7 суток - 17 новорожденным; 8-23 суток - 8 новорожденным. Использован патент на полезную модель «Способ диагностики степени тяжести аспирационного синдрома у новорожденных с перинатальным поражением цнС», которую проводят путем проведения рентгенографии органов грудной клетки.

Результаты. С помощью рентгенологического обследования органов грудной клетки в новорожденных с перинатальным поражением центральной нервной системы I степень аспирационного синдрома выявлена у 16 (53,3\%) новорожденных, II степень - у 12 (40\%) детей, III степень у 2 (6,7\%) малышей. При более ранней рентгенологической диагностике (до 3 суток) установлена легкая степень аспирационного синдрома без осложнений.

Выводы. Определения рентгенологических критериев степени тяжести аспирационного синдрома позволяют более объективно оценить состояние новорожденного. Рентгенологические критерии степени тяжести аспирационного синдрома позволяют не только установить правильный диагноз, но и контролировать эффективность своевременно проведенного лечения и предупредить развитие осложнений.

Ключевые слова: новорожденные, аспирационный синдром, рентгенография органов грудной клетки, перинатальные поражения цнС.

PERINATOLOGIYA I PEDIATRIYA.2015.2(62):94-96; doi10.15574/PP.2015.62.94

The role of perinatal pathology as the origin of occurrence of aspiration syndrome among neonates, its diagnostics

S. O. Izumec, O.I. Izumec, I.V. Galaktionova, T.V. Murashko

N.I. Pirogov Vinnitsa National Medical University, Ukraine

Vinnitsa regional children hospital

Vinnitsa regional endocrinological dispensary

Aspiration syndrome and its implications are very relevant topic. According to official statistics, the structure of the main causes of fetal death aspiration of amniotic fluid occupies the 5 th place among maternity injuries, accounting for $0.6 \%$. Therefore, an important task is to improve the neonatologists and clinical and radiological diagnostic methods like aspiration syndrome and its severity in infants during the first hours of life.

Key words: infants, aspiration syndrome diagnosis.

Сведения об авторах:

Изюмец Светлана Александровна - врач-гинеколог-эндокринолог Винницкого областного эндокринологического диспансера. Тел. (093) 254-85-64.

Изюмец Ольга Ивановна - к.мед.н., доц. каф. детских болезней №2 Винницкого НМУ

им. М.И. Пирогова, Винницкая областная детская клиническая больница. Тел. (093) 254-85-64.

Галактионова Инна Васильевна - врач детский невропатолог Винницкой областной детской клинической больницы.

Тел. (067) 509-47-14.

Мурашко Татьяна Владимировна - врач-интерн педиатр, магистрант каф. детских болезней №2 Винницкого НМУ

им. М.И. Пирогова, Винницкая областная детская клиническая больница. Тел. (093) 920-75-53.

Статья поступила в редакцию 30.04.2015 г. 


\title{
О.В. Оніськова, Л.О. Ющенко, Г.О. Коваленко Ранній початок статевого життя в підлітків: причини та наслідки
}

\author{
Вінницький національний медичний університет імені М.І. Пирогова, м. Вінниця, Україна
}

PERINATOLOGIYA I PEDIATRIYA.2015.2(62):97-100;doi10.15574/PP.2015.62.97

\begin{abstract}
Мета - оцінити сексуальну активність сучасних підлітків; вивчити рівень знань щодо статевого розвитку, транссексуальних захворювань, видів контрацепції; розробити можливі кроки для збереження репродуктивного здоров'я молоді.

Пацієнти та методи. Проведено анкетування серед підлітків - учнів 10-11-х класів чотирьох загальноосвітніх шкіл міста Вінниці та студентів Вінницького медичного коледжу. Вибірка респондентів становила 295 осіб, із них було 124 (42,04\%) хлопці та 171 (57,96\%) дівчина віком 15-17 років. Середній вік юнаків дорівнював $16 \pm 1,5$ року, дівчат - 16 $\pm 1,1$ року. Анкети були повністю анонімними, гарантувалось збереження таємниці отриманих даних. Доступ до отриманих результатів мали тільки дослідники. Опитування проводилось після одержання інформованої згоди батьків учнів та адміністрації навчального закладу. У випадку небажання відповідати на відверті запитання підлітки мали право відмовитися від заповнення опитувальника або окремих його питань.

Результати. Репродуктивна поведінка сучасних підлітків характеризується раннім початком статевого життя, зміною сексуальних партнерів, недостатнім використанням засобів контрацепції, високим рівнем підліткових вагітностей та абортів, що впливає на загальний стан репродуктивного здоров'я. Інформованість підлітків про статевий розвиток, захворювання, які передаються статевим шляхом, види контрацепції є недостатніми для формування мотивації для збереження репродуктивного здоров'я в підлітків.

Висновки. Бажаним вважаємо впровадження спеціальних занять зі статевого виховання в умовах середньої школи з поширенням спеціальних інформаційних листів в електронному або друкованому варіантах для самостійного опрацювання, залучення Інтернет-ресурсів за тематикою статевого виховання, створення молодіжних проектів для комплексної роботи з підлітками, здійснення доступної медико-профрілактичної допомоги в державних медичних закладах із широким інформуванням про наслідки раннього початку статевого життя, абортів і необхідність використання методів контрацепції. Ключові слова: підлітки, репродуктивна поведінка, сексуальний дебют.
\end{abstract}

\section{Вступ}

У сучасному суспільстві вік сексуального дебюту стрімко знижується [2, 4, 9, 11]. За даними електронного тижневика «Демоскоп», середній вік початку статевого життя сучасних підлітків становить 15-16 років. Більшість спеціалістів вважають цю тенденцію негативною та зазначають, що це може мати ряд негативних наслідків у майбутньому [17]. Насамперед це стосується погіршення репродуктивного здоров'я молоді: зростання випадків транссексуальних хвороб, виникнення незапланованих вагітностей, підліткових пологів та абортів $[2,3,7,8,10,11,16]$. Завагітнівши, багато дівчат приховують цей факт, намагаються позбутися дитини будь-яким способом. Для них цілком очевидним є виконання медичного аборту, про наслідки якого зазвичай не думають. Поряд із цим, пологи у молодої дівчини, організм якої ще не закінчив свій ріст та розвиток, можуть мати ризик для життя. Медико-соціальними факторами збереження високого рівня незапланованих вагітностей у підлітків та молоді є: низький рівень сексуальної культури в країні, безвідповідальне ставлення партнерів до сексуальних відносин, небажання почути інформацію про контрацепцію та використовувати їі у своєму особистому житті, низький рівень доходів населення і відносно високі ціни на протизаплідні засоби [9].

Окрім безпосередньої небезпеки для життя, суттєвими є психологічні порушення, які стають причинами безвідповідальної та небезпечної сексуальної поведінки в подальшому житті, сприяють розвитку депресій та провокують молодих людей на самогубство [12, 13, 18]. Діти старшого віку внаслідок своєї психічної незрілості не можуть об'єктивно оцінити кожну ситуацію, пов'язану 3 реалізацією своєї гіперсексуальності, на них значною мірою впливає сексуальний досвід оточення, що спонукає до ранньої сексуальної активності [4]. Типовими для сучасного суспільства є акселерація та пов'язаний з нею ранній розвиток сексуальних стосунків [2]. Часто основну роль у формуванні стереотипу поведінки підлітків відіграє телебачення, зарубіжні фільми, преса. Сьогодні засоби масової комунікації активно транслюють інформацію про сексуальність особистості, оминаючи соціальні й моральні норми. На фоні лібералізації сексу в суспільстві наголошується на зниженні впливу батьків на власних дітей [1]. Прихованою причиною раннього сексуального дебюту є сексуальне насилля, фізичне або у вигляді психологічного тиску чи шантажу з боку партнера [15].

Молоді люди потребують інформації та навиків для захисту їхного репродуктивного та сексуального здоров'я, саме тому світове товариство прийняло низку заходів, спрямованих на визначення напрямків такої освіти $[14,19]$. Робота з учнями шкільних закладів, батьківські настанови, освітні лекції та профілактичні огляди медичними працівниками можуть вплинути на репродуктивні плани молоді, а завдяки цьому потенційно поліпшити демографічну ситуацію в Україні в майбутньому $[2,5,6]$.

Meта роботи - оцінити сексуальну активність сучасних підлітків; вивчити рівень знань щодо статевого розвитку, транссексуальних захворювань, видів контрацепції; розробити можливі кроки для збереження репродуктивного здоров'я молоді.

\section{Матеріали та методи дослідження}

Матеріалом для дослідження були підлітки учні 10-11-х класів чотирьох загальноосвітніх шкіл міста Вінниці та студенти Вінницького медичного коледжу. Вибірка респондентів становила 295 осіб, із них було 124 (42,04\%) хлопці та 171 (57,96\%) дівчинка віком 15-17 років. Середній вік юнаків дорівнював $16 \pm 1,5$ року, дівчат $-16 \pm 1,1$ року.

У зміст анкети, використаної для опитування, включені такі запитання:

- вік, стать, склад сім'ї, сімейний стан;

- чи живуть статевим життям, у якому віці був дебют;

- причини початку статевого життя та чи було це заплановано;

- чи вживали алкогольні напої або наркотичні речовини перед статевим актом;

- чи вважали себе готовим до початку статевого життя;

- чи була різниця у віці з першим сексуальним партнером (якщо так, то вказати яка саме); 
- чи використовували засоби контрацепції під час статевого акту, якщо так, то уточнити які саме;

- чи були наслідки початку статевого життя (небажана вагітність, захворювання тощо);

- чи продовжують жити статевим життям, скільки сексуальних партнерів змінили;

- чи мають інформацію про статевий розвиток, захворювання, які передаються статевим шляхом та види контрацепції;

- джерела інформації сексуального виховання.

Анкети були повністю анонімними, гарантувалось збереження таємниці отриманих даних. Доступ до отриманих результатів мали тільки дослідники. Опитування проводилось після одержання інформованої згоди батьків учнів та адміністрації навчального закладу. У випадку небажання відповідати на відверті запитання підлітки мали право відмовитися від заповнення опитувальника або окремих його питань.

Для вивчення рівня вагітностей та абортів у неповнолітніх проводився аналіз річних звітів жіночої консультації Вінницького міського клінічного пологового будинку № 1 за 2011-2013 роки.

\section{Результати дослідження та їх обговорення}

Аналіз отриманих даних показав, що 45,16\% хлопців і 38,01\% дівчат у зазначеному віковому діапазоні живуть статевим життям. Вікова структура дебюту статевого життя у хлопців була така: більшість (51,78\%) почала статеве життя у 17 років, третина (33,92\%) - у 16 років, $12,50 \%-$ у 15 років, $1,80 \%$ - у 14 років. Відмінним виявився розподіл серед дівчат: дві третини почали статеве життя у 15-16 років (32,30\% та 38,46\% відповідно), близько десятої частини $(10,78 \%)$ - у більш ранньому віці (до 14 років), $18,46 \%$ у більш старшому (17 років). Відомо, що 54,91\% підлітків проживали в повних сім'ях, решта $(45,09 \%)$ мали лише одного з батьків або виховувалися бабусею та дідусем. Цікавим виявився той факт, що опитані діти з повних сімей $(45,06 \%)$ частіше вступали у ранні статеві відносини, ніж їхні однолітки з неповних родин $(36,09 \%),(\mathrm{p}>0,05)$.

Основним фактором початку статевого життя серед опитаних хлопців були такі причини: $46,42 \%$ юнаків вважали це проявом кохання, 28,57\% просто хотіли спробувати та набути досвіду, 3,57\% - вмовила партнерша, 21,44\% були під впливом алкогольного сп'яніння та не контролювали повністю свої дії. Третина $(38,46 \%)$ дівчат вважали початок статевого життя проявом кохання, така ж кількість (33,84\%) були вмовлені партнером на перший статевий акт. Усього 10,78\% дівчат хотіли спробувати з цікавості та 16,92\% вживали слабоалкогольні напої, ставали більш доступними та вважали це основною причиною позбавлення невинності. Але загалом 47,10\% підлітків зізналися у вживанні спиртного перед статевими відносинами (з них $57,14 \%$ хлопців і $38,46 \%$ дівчат, р<0,05), жоден із опитаних підлітків не приймав наркотичних речовин.

Лише 21,48\% підлітків (14,28\% хлопців і 27,69\% дівчат) планували початок статевого життя, решта $(78,52 \%)$ зазначили, що це сталося випадково. На питання, про оптимальний вік початку статевого життя 67,76\% відповіли, що почали статеве життя саме в тому віці, коли потрібно, 23,96\% опитаних (з них 16,07\% юнаків і 30,76\% дівчат) - занадто рано, 8,28\% (3 них 14,28\% юнаків і 3,07\% дівчат) - занадто пізно.

Відомо, що вікова різниця між першими сексуальними партнерами має значення у формуванні майбутньої сексуальної поведінки. Опрацювавши анкети, нами виявлено, що 78,51\% підлітків (62,50\% хлопців і 92,30\% дівчат, $\mathrm{p}<0,05)$ почали статеве життя зі старшими партнерами. Найчастіше різниця у віці становила $2-4$ роки, у 2,42\% випадків - 6 років. Юнаки частіше $(14,28 \%)$, ніж дівчата $(7,69 \%)$, вступали в перший сексуальний контакт з однолітками $(\mathrm{p}>0,05)$. Серед опитаних дівчат не було випадків, коли статевий партнер був молодшим, а хлопці у 23,21\% випадків обирали молодших за віком.

Що стосується використання засобів контрацепції, виявлено, що 95,04\% підлітків користувалися бар'єрними засобами (презервативами), 4,96\% не користувались контрацептивами взагалі. Незважаючи на нерегулярність і непередбаченість статевого життя в молоді, випадків використання екстреної контрацепції не виявлено. У запропонованій анкеті наведено такі види попередження вагітності: бар'єрні (презервативи), гормональні (комбіновані оральні контрацептиви), хімічні (аерозолі, креми, свічки), біологічні (температурний, календарний методи, перерваний статевий акт) та жоден з опитаних не обрав будь-який інший із запропонованих, окрім бар'єрних, що може вказувати на недостатній рівень обізнаності у виборі методів контрацепції. Жоден із респондентів, що почав статеве життя, не мав після цього негативних наслідків у вигляді захворювань або небажаної вагітності. $59,50 \%$ підлітків (з них 60,71\% хлопців і 58,46\% дівчат) продовжували жити статевим життям, із них чверть мали 2 та 3 сексуальні партнери, решта - одного.

На жаль, більшість (57,96\%) опитаних учнів інформацію про статевий розвиток, захворювання, які передаються статевим шляхом, види контрацепції отримали від своїх однолітків, 18,98\% - із засобів масової інформації, книжок, журналів та значно менше знань передали вчителі, батьки та лікарі (10,87\%, 7,79\%, 4,40\% відповідно).

На другому етапі дослідження опрацьовано річні звіти за 2011-2013 рр. жіночої консультації Вінницького пологового будинку № 1. Протягом трьох років зареєстровано 39 підліткових вагітностей, із них 28,20\% - у віці 14 років, $12,82 \%$ - у віці 15 років, 20,51\% - у віці 16 років, 38,46\% у віці 17 років. 3 них небажаних, які закінчились медичними абортами, було $8(20,51 \%)$ вагітностей, із них $2,56 \%$ у віці 14 років, по 5,13\% - у віці 15 і 16 років та 7,69\% - у віці 17 років. Відмічено зростання випадків незапланованих вагітностей у неповнолітніх, які закінчились абортами: y 2011 p. $-12,50 \%$, y 2012 p. $-8,33 \%$, y 2013 p. $-24,00 \%$.

\section{Висновки}

Репродуктивна поведінка сучасних підлітків характеризується раннім початком статевого життя, зміною сексуальних партнерів, недостатнім використанням засобів контрацепції, високим рівнем підліткових вагітностей та абортів, що впливає на загальний стан репродуктивного здоров'я.

Інформованість підлітків про статевий розвиток, захворювання, які передаються статевим шляхом, види контрацепції є недостатніми для формування мотивації для збереження репродуктивного здоров'я в підлітків.

Бажаним вважаємо впровадження спеціальних занять зі статевого виховання в умовах середньої школи з поширенням спеціальних інформаційних листів в електронному або друкованому варіантах для самостійного опрацювання, залучення Інтернет-ресурсів за тематикою статевого виховання, створення молодіжних проектів для комплексної роботи з підлітками, здійснення доступної медико-профілактичної допомоги в державних медичних закладах із широким інформуванням про наслідки раннього початку статевого життя, абортів і необхідність використання методів контрацепції. 


\section{ЛITЕРАТУРА}

1. Анализ факторов, влияющих на половое поведение и репродуктивное здоровье современных подростков / В.Н. Шевченко, А.С. Костюченко, Н.А. Мороз [и др.] // Здоровье женщины. 2010. - № 10. - С. 110-112.

2. Вовк І.Б. Сексуальна та репродуктивна поведінка підлітків / І.Б. Вовк // Здоров'я України. - 2009. - № 19/1. - С. 76.

3. Дудіна О.О. Деякі характеристики репродуктивного здоров'я жінок України / О.О. Дудіна, Г.Я. Пархоменко, Ю.Ю. Габорець // Здоровье женщины. - 2011. - № 7. - С. 146-151.

4. Каденко О.А. Ранні сексуальні зв'язки у підлітків, причини і наслідки / О.А. Каденко, 3.О. Антонова // Медична психологія. - 2009. № 4. - C. 80-83.

5. Могілевкіна І.О. Вивчення ставлення школярів до материнства і батьківства та рівня знань щодо плідності, вагітності / І.О. Могілевкіна, В.О. Перетятько, Г.А. Перетятько // Медико-социальные проблемы. - 2014. - № 1 (т. 19). - С. 71-76.

6. Перетятько В.О. Медико-соціальні чинники демографічної кризи в Україні очима школяра / В.О. Перетятько, Г.А. Перетятько // Медико-социальные проблемы. - 2013. - № 4 (т. 18). - С. 71-77.

7. Скворцова Е.С. Сексуальное поведение подростков, учащихся училищ начального профессионального образования России / Е.С. Скворцова, Н.З. Никифорова, Н.З. Зубкова // Здравоохранение Рос. Федерации. - 2010. - № 2. - С. 29-32.

8. Стан репродуктивного здоров'я дівчат та дівчат-підлітків України / Т.Ф. Татарчук, Л.В. Калугіна, В.М. Коломейчук, Н.Г. Руденко // Здоровье женщины. - 2011. - № 7. - С. 152-157.

9. Тучкіна І.О. Небажана вагітність у підлітків та молоді: проблема чи вирішення питання поліпшення демографічної ситуації? / І.О.Тучкіна // Здоровье женщины. - 2010. - № 10 (56). - С. 31-33.

10. Associations between early first sexual intercourse and later sexual and reproductive outcomes: A Systematic Review of Population-Based
Data / W. Heywood, K. Patrick, A.M. Smith [et al.] // Arch. Sex Behav. 2014. №26. - P. 15-21.

11. Baumgartner J.N. The influence of early sexual debut and sexual violence on adolescent pregnancy: a matched case-control study in Jamaica / J.N. Baumgartner, C.W. Geary // International Perspectives on Sexual and reproductive Health. - 2009. - Vol. 35, № 1. - P. 21-28.

12. Chiao $\mathrm{C}$. The influence of early sexual debut and pubertal timing on psychological distress among Taiwanese adolescents / C. Chiao, K. Ksobiech // Psychol. Health Med. - 2014. - №13. - P. 1-7.

13. Developmental pathways to sexual risk behavior in high-risk adolescent boys / S. L. Sitnick, L.M. Brennan, E. Forbes [et al.] // Pediatrics. 2014. - Vol.133, №6. - P. 1038-1045.

14. Haberland N. Sexuality education: emerging trends in evidence and practice / N. Haberland, D. Rogov // J. of Adolescent Health. 2015. - № 56. - P. 15-21.

15. Martin E.K. How much child sexual abuse is «below the surface», and can we help adults identify it early? / E.K. Martin, P.H. Silverstone // Frontiers in psychiatry. - 2013. - Vol. 4, № 58. - P. 1-8.

16. Prevalence and determinant of adolescent pregnancy in urban disadvantaged settings across five cities / H. Brahmbhatt, A. Kagesten, M. Emerson [et al.] // J. of Adolescent Health. — 2014. — № 55. - P. 48-57.

17. Sexual debut before the age of 14 leads to poorer psychological health risky behaviour in later life / A.A. Kastbom, G. Sudsjo, M. Bladh [et al.] // Acta Pediatrica. - 2015. - Vol. 1, №4. - P. 91-100.

18. Stephenson R. Community Factors shaping early age at first sex among adolescent in Burkina Faso, Ghana, Malawi, and Uganda / R. Stephenson, C. Simon, C. Finneran // J. Health Popul Nutr. - 2014. - Vol. 32, № 2. - P. 161-175.

19. Twenty ears after International Conference on population and development: where are we with adolescent sexual and reproductive health and rights? / Venkatraman Chandra-Mouli, Joar Svanemyr, Avni Amin [et al.] // J. of Adolescent Health. - 2015. - № 56. - P. 1-6.

\section{Раннее начало половой жизни у подростков: причины и следствия \\ О.В. Ониськова, Л.А. Ющенко, А.О. Коваленко}

Винницкий национальный медицинский университет имени Н.И. Пирогова, г. Винница, Украина

цель - оценить сексуальную активность современных подростков; изучить уровень знаний относительно полового развития, транссексуальных заболеваний, видов контрацепции; разработать возможные шаги для сохранения репродуктивного здоровья молодежи.

Пациенты и методы. Проведено анкетирование среди подростков - учеников 10-11-х классов четырех общеобразовательных школ города Винницы и студентов Винницкого медицинского колледжа. Выборка респондентов составляла 295 лиц, из них были 124 (42,04\%) мальчика и 171

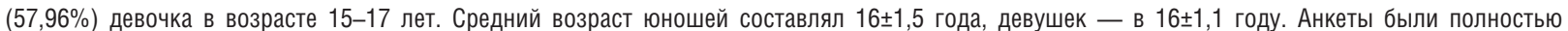
анонимными, гарантировалось сохранение тайны полученных данных. Доступ к полученным результатам имели только исследователи. Опрос проводился после получения информированного согласия родителей учеников и администрации.

Результаты. Репродуктивное поведение современных подростков характеризуется ранним началом половой жизни, изменением сексуальных партнеров, недостаточным использованием средств контрацепции, высоким уровнем подростковых беременностей и абортов, что влияет на общее состояние репродуктивного здоровья. Информированность подростков о половом развитии, заболеваниях, которые передаются половым путем, виды контрацепции являются недостаточными для формирования мотивации для сохранения репродуктивного здоровья у подростков.

Выводы. Желательным считаем внедрение специальных занятий по половому воспитанию в условиях средней школы с распространением специальных информационных писем в электронном или распечатанном вариантах для самостоятельной проработки, привлечения Интернетресурсов, по тематике полового воспитания, создания молодежных проектов для комплексной работы с подростками, осуществления доступной медико-просилактической помощи, в государственных медицинских заведениях с широким информированием о последствиях раннего начала половой жизни.

Ключевые слова: подростки, репродуктивное поведение, сексуальный дебют.

PERINATOLOGIYA I PEDIATRIYA.2015.2(62):97-100;doi10.15574/PP.2015.62.97

Early onset of sexual activity among adolescents: Causes and Consequences

O.V. Oniskova, L.A. Yushchenko S.A. Kovalenko

Vinnitsa National Medical University named after NI Pirogov, Vinnitsa, Ukraine

Purpose - to estimate the sexual activity of modern teenagers; examine the level of knowledge about sexual development, transsexual diseases, types of contraception; develop possible steps to preserve the reproductive health of young people. 
Patients and methods. A survey among teenagers - pupils of 10-11 grades of four schools of Vinnitsa and Vinnitsa medical college students. The sample of respondents was 295 persons, 124 of them (42.04\%) boys and $171(57.96 \%)$ Girl aged $15-17$. The average age of the young men was $16 \pm 1,5$ years, women $-16 \pm 1,1$ year. The survey was completely anonymous, guaranteed confidentiality of the data. Access to the results obtained were only researchers. The survey was conducted after obtaining the informed consent of the parents of students and the administration.

Results. Reproductive behavior of teenagers today is characterized by early onset of sexual activity, a change in sexual partners, insufficient use of contraceptives, a high level of teenage pregnancies and abortions, which affects the overall reproductive health. Awareness of adolescent sexual development, diseases that are transmitted sexually, types of contraception are inadequate for the formation of motivation for the reproductive health of adolescents. Conclusions. Desirable to consider the introduction of special classes on sex education in a secondary school with the spread of specialized newsletters in electronic or print versions for self-study, to attract Internet resources on the subject of sex education, the creation of youth projects for complex work with teenagers, of the availability of medical and preventive assistance in public health institutions with a broad awareness of the effects of early sexual activity.

Key words: adolescents, reproductive behavior, sexual debut.

\section{Сведения об авторах:}

Ониськова Оксана Валерьевна - к.мед.н., доц. каф. пропедевтики детских болезней Винницкого НМУ им. М.И. Пирогова. Адрес: г. Винница, ул. Пирогова,56.

Ющенко Леся Александровна - к.мед.н., ассистент каф. пропедевтики детских болезней Винницкого НМУ им. М.И. Пирогова. Адрес: г. Винница, ул. Пирогова,56.

Коваленко Анна Олеговна - студентка Винницкого НМУ им. М.И. Пирогова. Адрес: г. Винница, ул. Пирогова,56.

Статья поступила в редакцию 30.04.2015 г.

\section{НОВОСТИ}

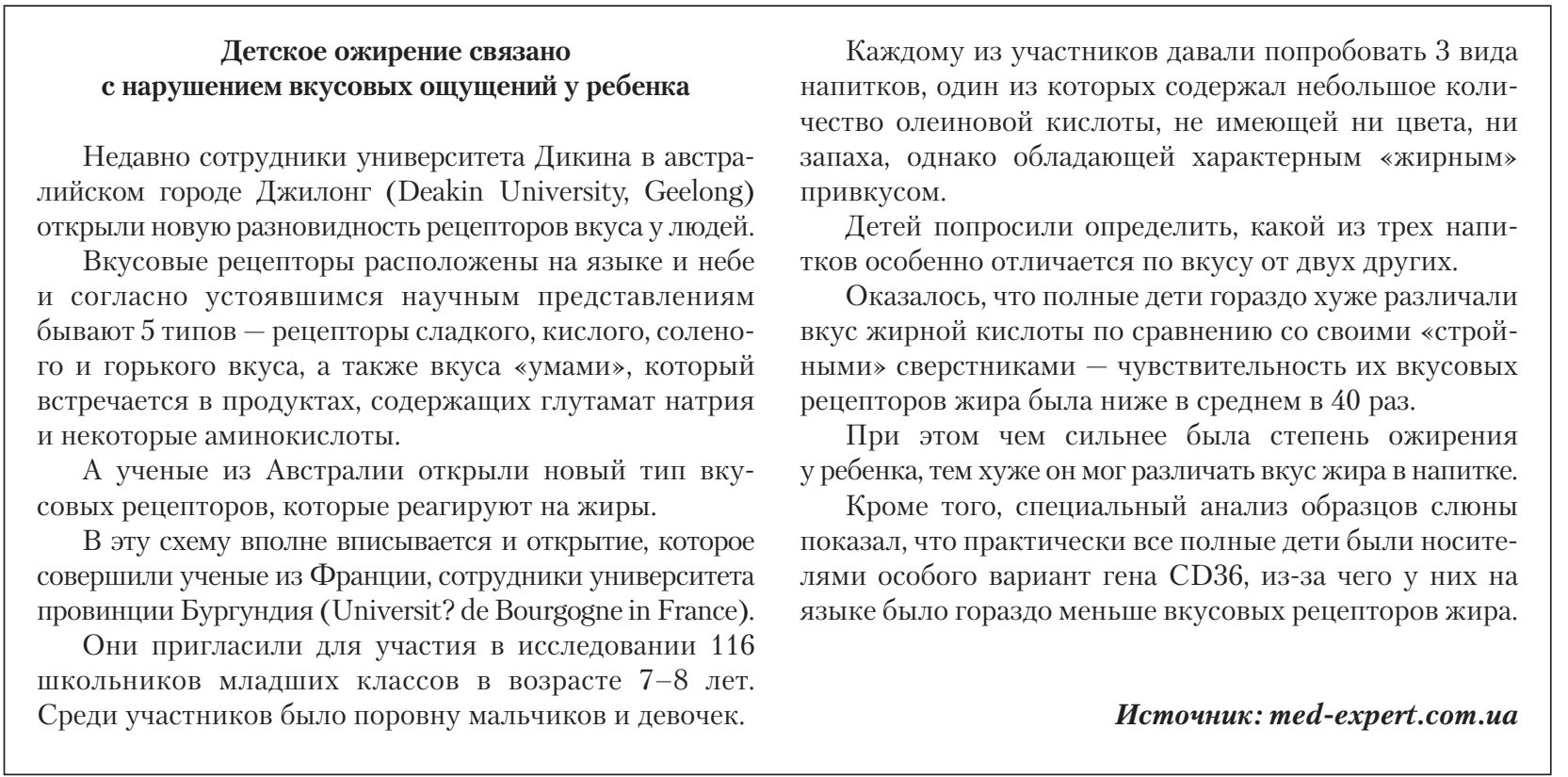




\title{
К СВЕДЕНИЮ АВТОРОВ Правила подачиматериала для публикации:
}

\begin{abstract}
- Структура материала: введение (состояние проблемы по данным литературы не более 5-7-летней давности); цель, основные задания и методы исследования; основная часть (освещение статистически обработанных результатов исследования); выводы; перспективы дальнейшего развития в данном направлении; список литературы, рефераты на русском, украинском и английском языках.
\end{abstract}

- Материал должен сопровождаться официальным направлением от учреждения, в котором он был выполнен, с визой руководства (научного руководителя), заверенной круглой печатью учреждения, и экспертным заключением о возможности в открытой печати.

- На последней странице статьи должны быть собственноручные подписи всех авторов, фамилия, имя и отчество (полностью), почтовый адрес, номера телефонов (служебный, домашний) автора, с которым редакция будет общаться.

- Авторский текстовый оригинал должен состоять из двух экземпляров на украинском или русском языке:

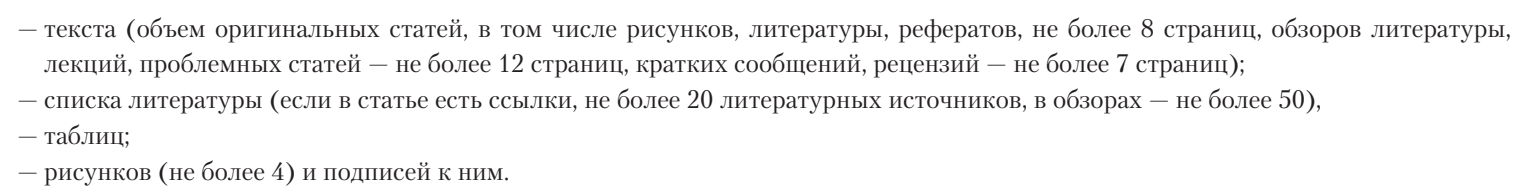

- К статье прилагаются рефераты на украинском, русском и английском языках с обязательным указанием фамилий и инициалов авторов на этих языках. Объем резюме не должен превышать 200-250 слов. Обязательно указываются «ключевые слова» (от 3 до 8 слов) в порядке значимости, способствующие индексированию статьи в информационно-поисковых системах. Резюме является независимым от статьи источником информации. Оно будет опубликовано отдельно от основного текста статьи и должно быть понятным без ссылки на саму публикацию. Резюме является кратким и последовательным изложением материала публикации по основным разделам и должно отражать основное содержание статьи, следовать логике изложения материала и описания результатов в статье с приведением конкретных данных.

- Резюме к оригинальной статье должно быть структурированным: а) цель исследования; б) материал и методы; в) результаты; г) заключение. Все разделы в резюме должны быть выделены в тексте жирным шрифтом. Для остальных статей (обзор, лекции, обмен опытом и др.) резюме должно включать краткое изложение основной концепции статьи и ключевые слова.

- Статьи набираются на компьютере в программе Word и подаются распечатанными с CD-диском (дискеты приниматься не будут). Текст реферата следует набирать шрифтом 12 пунктов с межстрочным интервалом - 1,5, придерживаясь таких размеров полей: верхний и нижний -20 мм, левый - 25 мм, правый - 10 мм. Иллюстрации (диаграммы, графики, схемы) строятся в программах Word или Ехсеl и в виде отдельных файлов и вместе с текстовым файлом подаются на диске.

- На первой странице указываются: индекс УдК слева, инициалы и фамилии авторов, город в скобках, название статьи, название учреждения, где работают авторы.

- Список литературы подается сразу же за текстом. Авторы упоминаются по алфавиту - сначала работы отечественных авторов, а также иностранных, опубликованных на русском или украинском языках, далее иностранных авторов, а также отечественных, опубликованных на иностранных языках. Все источники должны быть пронумерованы и иметь не более 5-7-летнюю давность.

- Ссылки в тексте обозначаются цифрами в квадратных скобках, должны отвечать нумерации в списке литературы. В библиографическом описании книги нужно указать фамилии и инициалы авторов, ее название (если четыре и более авторов - название книги, а потом за косой чертой инициалы и фамилии всех авторов или, если более четырех, трех авторов и слова «и др.»), город, издательство, год издания, общее количество страниц; статьи - фамилии и инициалы авторов, название периодического издания (журнала, сборника научных работ), год, номер (том, выпуск) и страницы (начальная и последняя); автореферата диссертации - фамилия и инициалы автора, название автореферата, далее с заглавной буквы после двоеточия указывают, на соискание какой степени защищается диссертация и в какой отрасли науки, когда и где защищалась (в каком научном учреждении), город и год издания, общее количество страниц. Сокращение слов и их соединений приводят согласно с ГСТУ 358297 «Соращения слов в украинском языке в библиографическом описании. Общие требования и правила».

- Количество иллюстраций (рисунки, схемы, диаграммы) должно быть минимальным. Таблицы и рисунки помещают в текст статьи сразу после первого упоминания их. В подписи к рисунку приводят его название, пояснение всех условных обозначений (цифр, букв, кривых и т.д.). Таблицы должны быть компактными, пронумерованными, иметь название. Номера таблиц, их заголовки и цифровые данные, обработанные статистически, должны точно отвечать приведенным в тексте.

- Обозначения разных мер, единицы физических величин, результаты клинических и лабораторных исследований следует приводить согласно Международной системы единиц (СИ), медицинские термины согласно Международной анатомической и Международной гистологической номенклатурам, названия заболеваний по Международной классификации заболеваний 10-го пересмотра, лекарственные средства по Державной Фармакопее (X, XI). Названия фирм и аппаратов необходимо подавать в оригинальной транскрипции.

- Сокращения в тексте слов, имен, терминов (кроме общеизвестных) не допускается. Аббревиатура расшифровывается после первого упоминания и остается неизменной во всем тексте.

- Ответственность за достоверность и оригинальность поданных материалов (фактов, цитат, фамилий, имен, результатов исследований и т.д.) полагается на авторов. Статьи, оформленные без соблюдения правил, не рассматриваются и не возвращаются авторам.

- Редакция обеспечивает рецензирование статей, выполняет специальное и литературное редактирование, оставляет за собой право сокращать объем статей. Отказ авторам в публикации статей может осуществляться без объяснения его причини и не считаться негативным заключением относительно научной и практической значимости работы. 


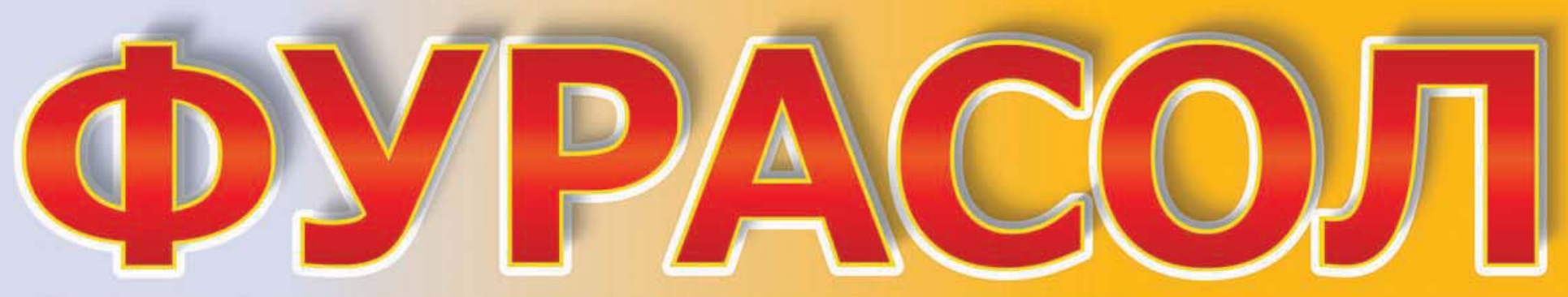

Ефективна, м'яка, безпечна антисептикотерапія слизових ротової порожнини та горла у дорослих та дітей з 4-х років.

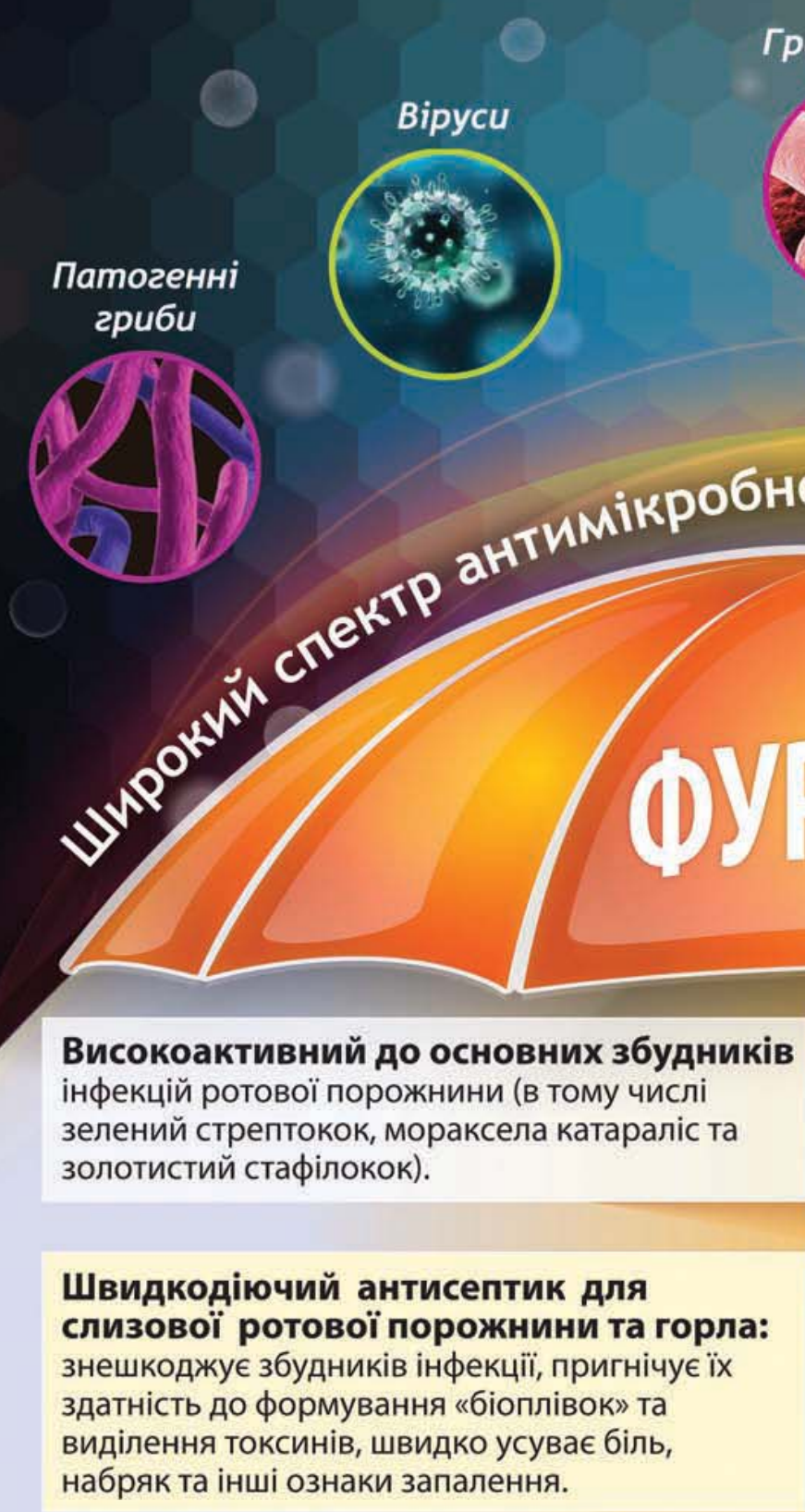

$\Gamma p(-)$ бактерії

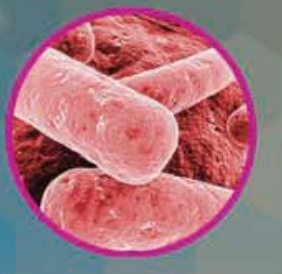

$\Gamma p(+)$ бактеріï

(в т.ч. Золотистий стафілокок)

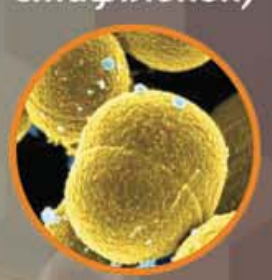

Проcmiwi 